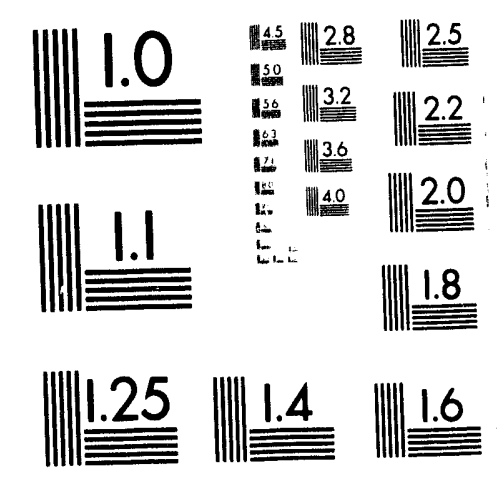



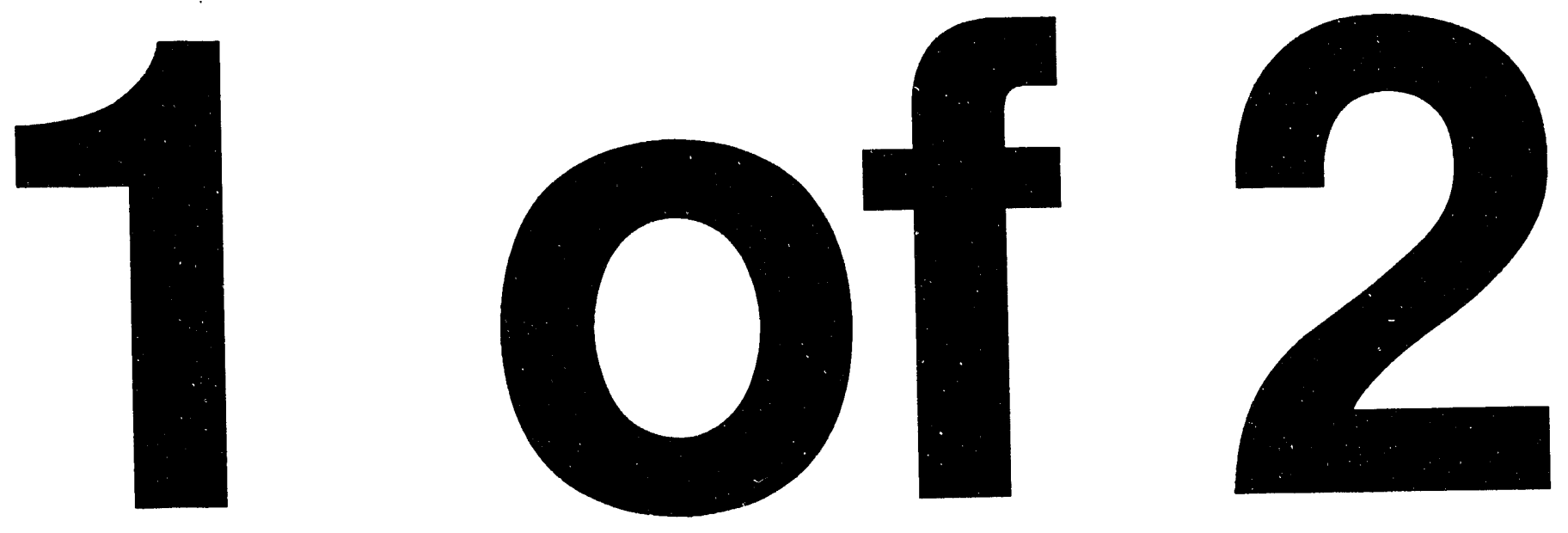
BAseline RISK ASSESSMENT Of Ground Water Contamination At The Uranium Mill Tallings Site Near Shiprock, NeW Mexico

April 1994

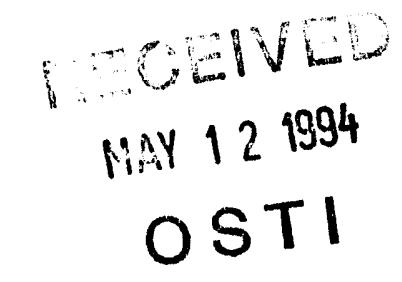




\section{INTENDED FOR PUBLIC RELEASE}

This report has been reproduced from the best available copy. Available in paper copy and microfiche.

Number of pages in this report: 178

DOE and DOE contractors can obtain copies of this report from:

Office of Scientific and Technical Information

P.O. Box 62

Oak Ridge, TN 37831

(615) 576-8401

This report is publicly available from:

National Technical Information Service

Department of Commerce

5285 Port Royal Road

Springfield, VA 22161

(703) 487-4650 


\title{
BASELINE RISK ASSESSMENT \\ OF GROUND WATER CONTAMINATION \\ AT THE URANIUM MILL TAILINGS SITE \\ NEAR SHIPROCK, NEW MEXICO
}

April 1994

\author{
Prepared for \\ U.S. Department of Energy \\ UMTRA Project Office \\ Albuquerque, New Mexico \\ Prepared by \\ Jacobs Engineering Group Inc. \\ Albuquerque, New Mexico
}




\section{CITIZENS' SUMMARY}

This baseline risk assessment at the former uranium mill tailings site near Shiprock, New Mexico, evaluates potential impact to public health or the environment resulting from ground water contamination at the former uranium mill processing site. The tailings and other contaminated material at this site were placed in an on-site disposal cell in 1986 through the U.S. Department of Energy (DOE) Uranium Mill Tailings Remedial Action (UMTRA) Project. Currently, the UMTRA Project is evaluating ground water contamination. This risk assessment is the first document specific to this site for the Ground Water Project.

There are no domestic or drinking water wells in the contaminated ground water of the two distinct ground water units: the contaminated ground water in the San Juan River floodplain alluvium below the site and the contaminated ground water in the terrace alluvium area where the disposal cell is located. Because no one is drinking the affected ground water, there are currently no health or erivironmental risks directly associated with the contaminated ground water. However, there is a potential for humans, domestic animals, and wildlife to be exposed to surface expressions of ground water in the seeps and pools in the area of the San Juan River floodplain below the site. For these reasons, this risk assessment evaluates potential exposure to contaminated surface water and seeps as well as potential future use of contaminated ground water.

This risk assessment follows the approach outlined by the U.S. Environmental Protection Agency (EPA). The first step is to evaluate ground water data collected from monitor wells at the site. Evaluating these data showed that the main contaminants in the floodplain ground water are arsenic, magnesium, manganese, nitrate, sodium, sulfate, and uranium. The complete list of contaminants associated with the terrace alluvium ground water could not be determined because of the lack of background ground water quality data. However, uranium, nitrate, and sulfate levels were evaluated because these chemicals are clearly associated with uranium processing and are highly elevated compared to regional waters. It also could not be determined if the ground water occurring in the terrace alluvium is a usable water resource, because it appears to have originated largely from past milling operations.

The next step in a risk assessment is to estimate how much of these contaminants people would be exposed to if a drinking well were installed in the contaminated ground water or if there were exposure to surface expressions of contaminated water. Exposure to surface water could occur from incidental contact with contaminated water or sediments as children play on the floodplain or from consumption of meat and milk from domestic animals that grazed and drank water on the floodplain.

These estimated amounts of contaminants that people might take in are then compared to the toxic effects these contaminant levels might cause. Based on this analysis, there would be no adverse health effects to children who played on the floodplain, waded in surface water, or incidentally drank surface water or sediments. Eating beef or drinking milk from animals that grazed and watered on the floodplain would not be associated with adverse health effects. 
The most significant health hazard in the ground water at the Shiprock mill site is nitrate. Nitrate levels in the floodplain ground water and terrace alluvium ground water near the site exceed reportedly lethal ingestion levels. For this reason, the DOE is working with the Navajo Nation to restrict access to contaminated ground water until the site can be further evaluated.

Other contaminants occurring at levels associated with adverse health effects in the floodplain ground water are sulfate, magnesium, manganese, and sodium. The sulfate and magnesium concentrations in the floodplain ground water and terrace alluvium ground water near the site would cause severe diarrhea and dehydration if ground water were ingested. The amounts of manganese potentially ingested would be expected to affect the nervous system with long-term exposure and sodium levels would contribute to the development of hypertension.

The uranium and arsenic concentrations in ground water at the site may increase the risk of cancer if it were ingested. The average additional cancer risk from ingesting uranium contaminated ground water for a lifetime would be 6 in 10,000 for the terrace alluvium and 1 in 1000 for the floodplain. The additional lifetime cancer risk from exposure to arsenic in the floodplain ground water would be 1 in 1000, on average.

This risk assessment also evaluated potential effects on livestock if the ground water were used to water cattle or sheep and if cattle or sheep drank water from the seeps of contaminated ground water while grazing on the floodplain. These animals are sensitive to nitrate. The nitrate concentrations near the former mill site are high enough to kill these animals if they drank the contaminated ground water. The nitrate levels in the wet area below seep 425 make this water unsuitable for drinking by animals grazing on the floodplain.

Potential impacts to the environment from contaminated ground water are not likely. Based on available water quality criteria for a number of contaminants of concern, no ecological threat exists to plants that may have roots in contact with the most contaminated ground water in the floodplain alluvial aquifer. However, potential use of this ground water would not be suitable for crop irrigation due to elevated levels of boron, manganese, and selenium, and due to the salinity and sodium hazard to the plants. This ground water would also not be suitable for fish to live in.

The mill tailings disposal cell on the terrace at the Shiprock site is currently being monitored. The Shiprock site will be further evaluated under the UMTRA Ground Water Project. This evaluation will include the terrace alluvium ground water and its movement and the floodplain ground water and surface water. Based on these results and this risk assessment, an approach will be developed to address water contamination. In the interim, access to contaminated ground water should be controlled. 


\section{TABLE OF CONTENTS}

\section{Section}

Page

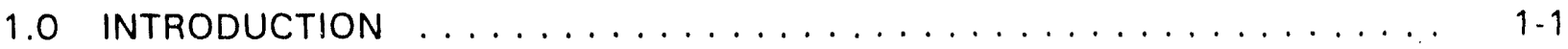

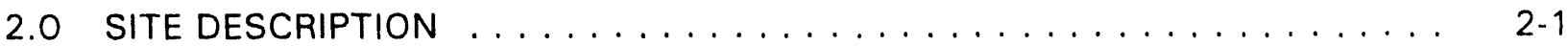

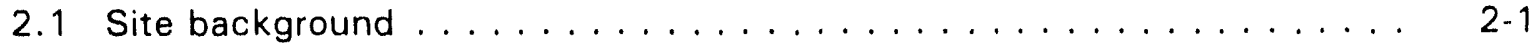

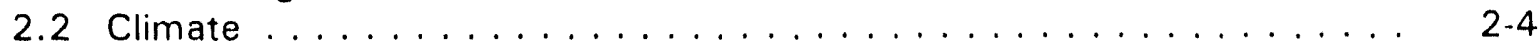

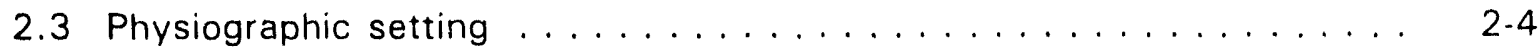

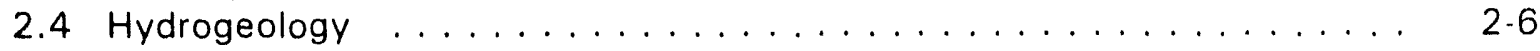

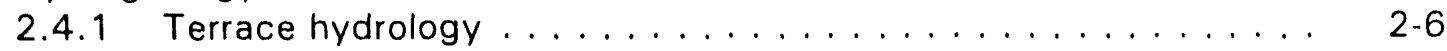

2.4 .2 Floodplain hydrology .................. $2-7$

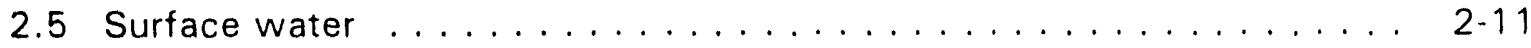

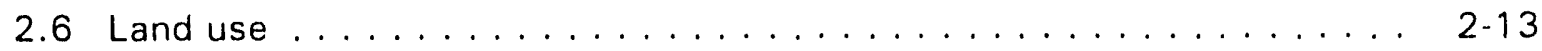

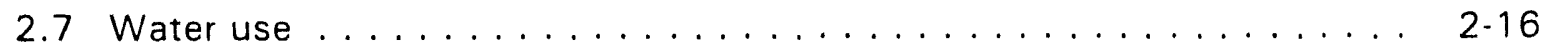

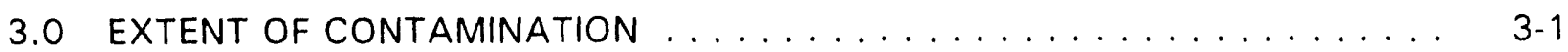

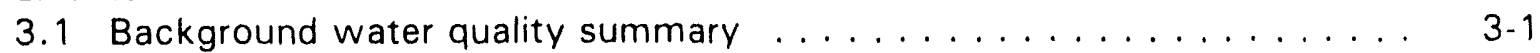

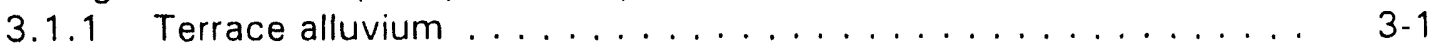

3.1 .2 Floodplain ...................... $3-1$

3.2 Magnitude of site-related contamination .............. $3-10$

3.2.1 Terrace alluvium ...................... 3-10

3.2.2 Alluvial floodplain .................... 3-10

3.3 Contaminants of potential concern ............... $3-20$

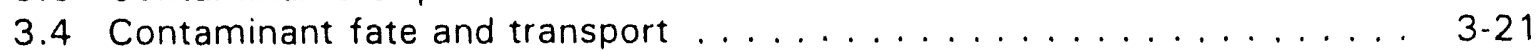

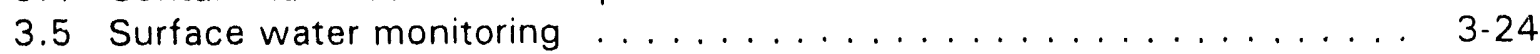

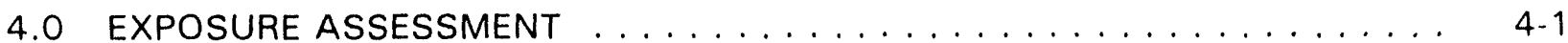

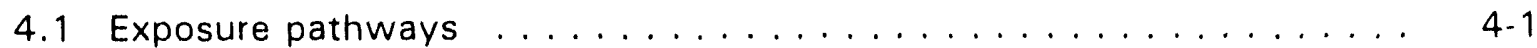

4.1.1 Ground water exposure pathways for the floodplain ........ 4. 4-1

4.1.2 Ground water exposure pathways for the terrace alluvium . . . . 4 4-3

4.1.3 Surface water exposure pathways for the floodplain area ..... 4-3

4.2 Potentially exposed population .................. 4.3

4.3 Exposure concentrations ....................... 4.5

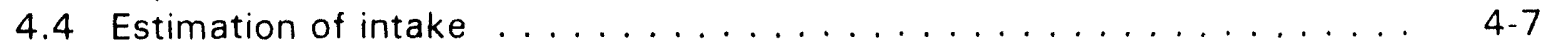

4.4.1 Floodplain ground water exposure routes . . . . . . . . . . . . 4.8

4.4.2 Terrace alluvium ground water exposure routes . . . . . . . . 4-13

4.4.3 Floodplain surface water exposure routes . . . . . . . . . . . 4.13

4.5 Exposure assessment uncertainties . . . . . . . . . . . . . . . 4-22

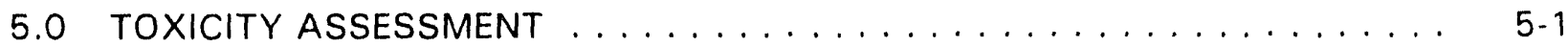

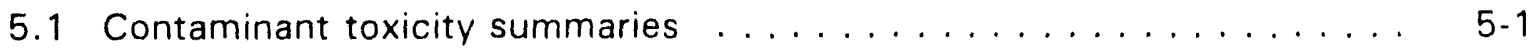

5.1 .1 Antimony ........................ $5-1$

5.1 .2 Arsenic ............................ 5.4

5.1 .3 Cadmium ........................ 5.6

5.1 .4 Magnesium ...................... $5-9$ 
TABLE OF CONTENTS (Concluded)

Section Page

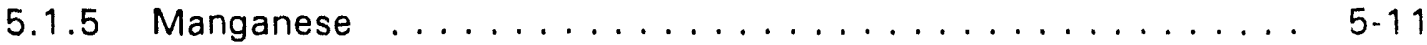

5.1 .6 Nitrate ........................ 5-16

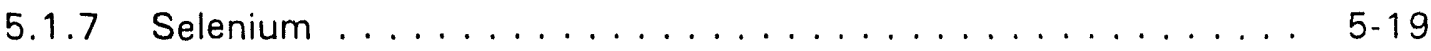

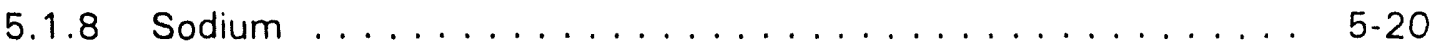

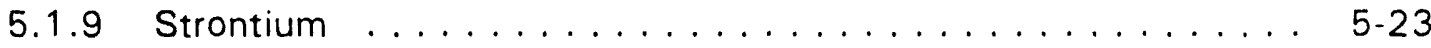

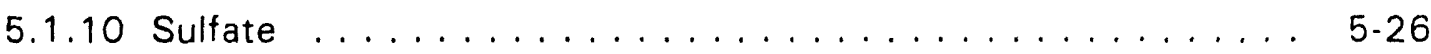

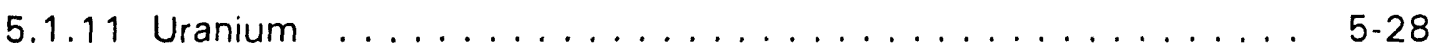

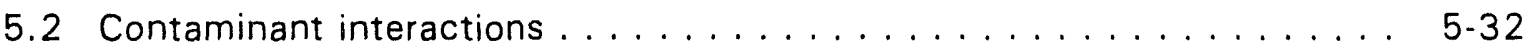

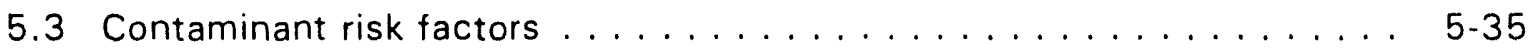

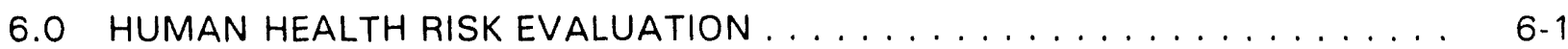

6.1 Potential noncarcinogenic health effects ................ 6-1

6.1 .1 Floodplain ground water potential use ............... 6-1

6.1 .2 Terrace alluvium ground water potential use . . . . . . . . . . 6-14

6.1.3 Floodplain surface water potential use . . . . . . . . . . . . . . . 6-14

6.2 Potential carcinogenic health effects ...................6.14

6.3 Limitations of risk evaluation .........................6-17

7.0 LIVESTOCK AND ENVIRONMENTAL EVALUATION ............... 7.1

7.1 Exposure characterization .................... 7.2

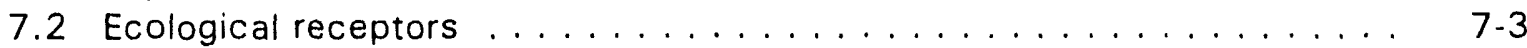

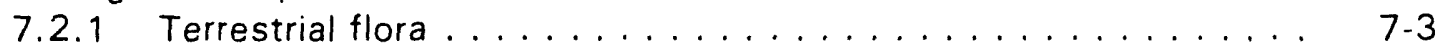

7.2 .2 Terrestrial fauna . . . . . . . . . . . . . . . . . $7-4$

7.2 .3 Aquatic organisms ......................... 7-5

7.3 Contaminants of ecological concern ................. 7-6

7.4 Potential impacts to wildlife and plants ................ 7-7

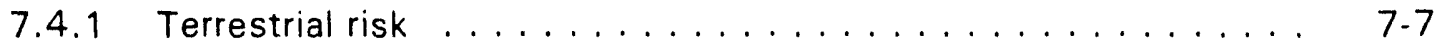

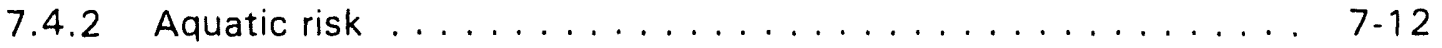

7.5 Potential impacts to livestock ..................... 7-19

7.6 Ecological risk assessment limitations . . . . . . . . . . . . . . . 7-22

7.7 Summary ............................ 7-22

8.0 INTERPRETATION AND RECOMMENDATIONS ................. 8

8.1 Risk summary ........................... 8-1

8.2 Limitations of this risk assessment ................... 8-1

8.3 Ground water criteria ........................ 8-3

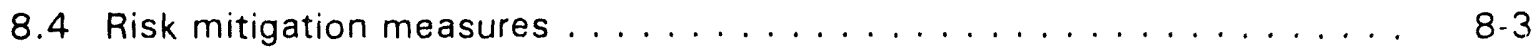

8.5 Recommendations ........................ 8 .5

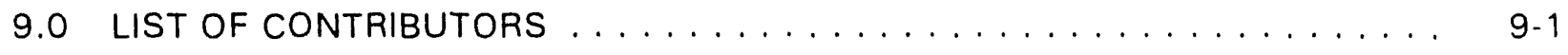

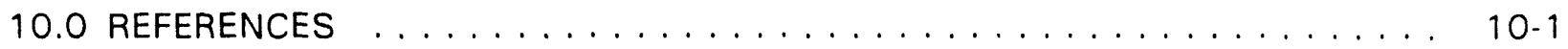




\section{LIST OF FIGURES}

Figure

Page

2.1 Shiprock site location map, Shiprock, New Mexico, site . . . . . . . . . . 2-2

2.2 Aerial view of Shiprock site in operating period,

Shiprock, New Mexico, site . . . . . . . . . . . . . . . . . . 2-3

2.3 Physiographic setting, Shiprock, New Mexico, site . . . . . . . . . . . 2-5

2.4 Bedrock surface contours on terrace, Shiprock, New Mexico, site . . . . . . . 2 2-8

2.5 Cross section A-A', Shiprock, New Mexico, site . . . . . . . . . . . . . . . 2-9

2.6 Ground water contours and gradient on floodplain,

Shiprock, New Mexico, site ... . . . . . . . . . . . . . . . . . . 2-10

2.7 Ground water sampling locations at Shiprock, New Mexico, site . . . . . . . . 2-12

2.8 Locations of flood plain surface water and sediment sampling stations

adjacent to Shiprock tailings site, Shiprock, New Mexico . . . . . . . . . . . 2-14

2.9 Land use in the vicinity of Shiprock, New Mexico, site, $1993 \ldots \ldots$. . . . . . . 2-15

3.1 Background wells used for qualitative and quantitative analysis of ground water in the alluvial aquifer, Shiprock, New Mexico, site . . . . . . . 3-2 3- . .

3.2 Sulfate isopleths, Shiprock, New Mexico, site . . . . . . . . . . . . . . 3-17

3.3 Nitrate isopleths, Shiprock, New Mexico, site . . . . . . . . . . . . . . 3-18

3.4 Uranium isopleths, Shiprock, New Mexico, site . . . . . . . . . . . . . 3-19

4.1 Conceptual model for the floodplain alluvium ground water use pathways ............................... 4-2

4.2 Conceptual model for the floodplain alluvium surface water use pathways ................................ 4-4

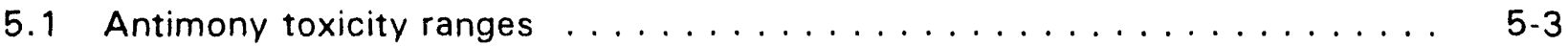

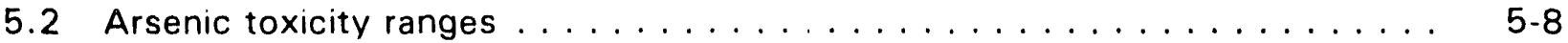

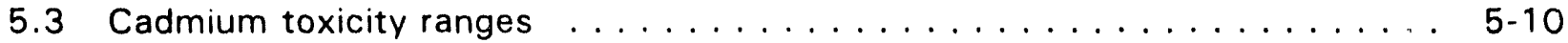

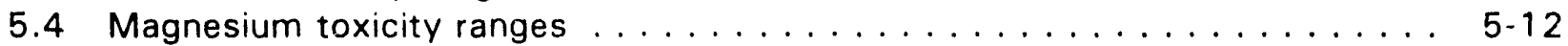

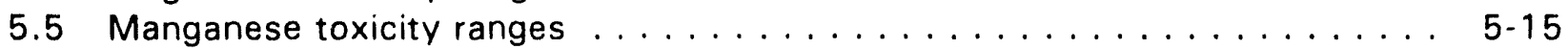

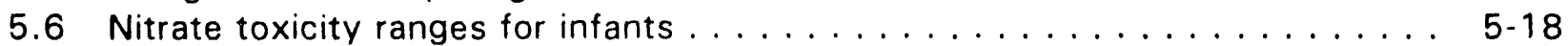

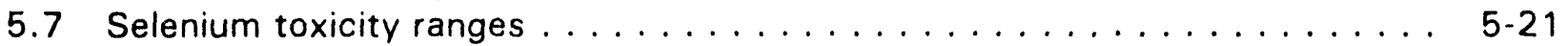

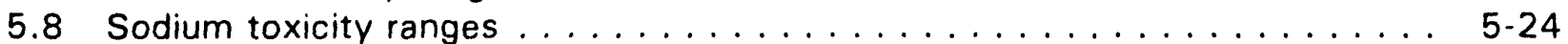

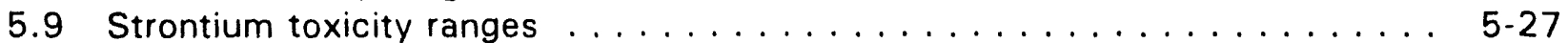

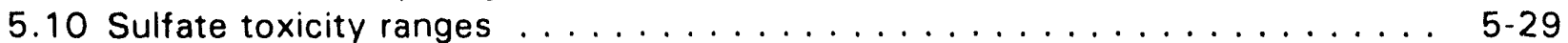

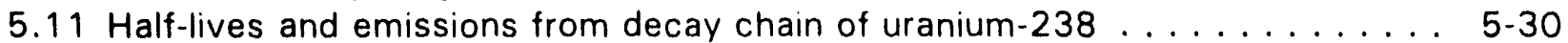

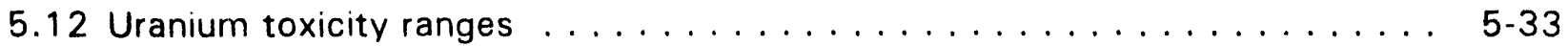

6.1 Health effects of potential nitrate exposure for infants, Shiprock, New Mexico, site . . . . . . . . . . . . . . . . . . . 6-2

6.2 Health effects of potential sulfate exposure for infants, Shiprock, New Mexico, site . . . . . . . . . . . . . . . . . . . . 6. 6-3

6.3 Health effects of potential arsenic exposure for adults, Shiprock, New Mexico, site . . . . . . . . . . . . . . . . . . . . . . . 6 6-4 


\section{LIST OF FIGURES (Concluded)}

Figure

Page

6.4 Health effects of potential cadmium exposure for adults,

Shiprock, New Mexico, site . . . . . . . . . . . . . . . . . . .

6.5 Health effects of potential uranium exposure for children

and adults, Shiprock, New Mexico, site . . . . . . . . . . . . . . . .

6.6 Health effects of potential magnesium exposure for adults,

Shiprock, New Mexico, site

6.7 Health effects of potential antimony exposure for adults,

Shiprock, New Mexico, site

6.8 Health effects of potential strontium exposure for children and adults, Shiprock, New Mexico, site . . . . . . . . . . . . . . . . .

6.9 Health effects of potential selenium exposure for children and adults, Shiprock, New Mexico, site . . . . . . . . . . . . . . . .

6.10 Health effects of potential manganese exposure for adults,

Shiprock, New Mexico, site

6.11 Health effects of potential sodium exposure for adults,

Shiprock, New Mexico, site

6.12 Increased lifetime cancer risk from potential arsenic exposure
for adults, Shiprock, New Mexico, site . . . . . . . . . . .

6.12 Increased lifetime cancer risk from potential arsenic exposure
for adults, Shiprock, New Mexico, site $\ldots \ldots \ldots \ldots \ldots \ldots \ldots \ldots$

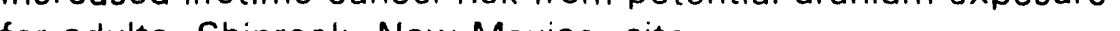

$6-16$ 


\section{LIST OF TABLES}

Table

Page

3.1 Wells used to determine background water quality . . . . . . . . . .

3.2 Statistical summary of the San Juan River floodplain ground water quality, 1987 - 1993 filtered samples,

Shiprock, New Mexico, site . . . . . . . . . . . . . . . . . .

3.3 Summary of ground water quality in the terrace alluviuin,

Shiprock, New Mexico, site, $1988-1993 \ldots \ldots \ldots \ldots \ldots$

3.4 Contaminants of potential concern for the San Juan River

floodplain, Shiprock, New Mexico, site . . . . . . . . . . . . . . . . 3-22

3.5 Chemical speciation . . . . . . . . . . . . . . . . . . . . 3-23

3.6 Statistical summary of the San Juan River water quality at the

Shiprock UMTRA site, New Mexico, February 25, $1993 \ldots \ldots \ldots \ldots \ldots$. . . . .

4.1 Exposure concentrations for the floodplain ground weter . . . . . . . . .

4.2 Exposure concentrations for the terrace alluvium ground water . . . . . . . . . .

4.3 Exposure concentrations for the floodplain surface water

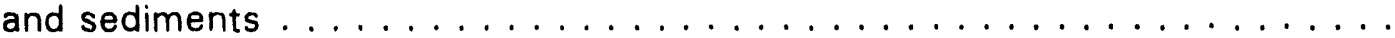

4.4 Quantitatively evaluated exposure routes ....................

4.5 Exposure dose calculations and equation definitions for ground water ingestion and dermal contact, Shiprock, New Mexico, site ...................................

4.6 Exposure dose calculations for ground water-irrigated garden produce ingestion in future hypothetical adult scenarios,

San Juan floodplain, Shiprock, New Mexico, site . . . . . . . . . . . . . . . . . . .

4.7 Exposure dose calculations for hypothetical adult scenario of ground water ingestion from the terrace alluvium, Shiprock, New Mexico, site . . . . . . . . . . . . . . . . . . . . .

4.8 Exposure dose calculations and equation definitions for hypothetical incidental surface water ingestion and dermal contact by children on the floodplain, Shiprock, New Mexico, site . . . . . . . . . .

4.9 Exposure dose calculations and equation definitions for hypothetical incidental ingestion of sediments by children on the floodplain, Shiprock, New Mexico, site . . . . . . . . . . . . . . .

4.10 Kd values for selected contaminants of concern based on sediment and surface water concentrations measured on the floodplain, Shiprock, New Mexico, site . . . . . . . . . . . . . . .

4.11 Estimated concentrations of selected contaminants of concern in pasture grasses on the San Juan River floodplain,

Shiprock, New Mexico, site . . . . . . . . . . . . . . . . . .

4.12 Exposure dose calculations for future hypothetical adult meat and milk consumption from cattle grazed and watered on the San Juan River floodplain, Shiprock, New Mexico, site . . . . . . . . . . . . . . 


\section{LIST OF TABLES (Concluded)}

Table

Page

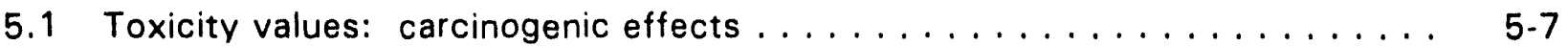

5.2 Toxicity values: potential noncarcinogenic effects $\ldots \ldots \ldots \ldots \ldots$ 5-36

6.1 Carcinogenic risk for the floodplain ground water consumption pathway at the Shiprock, New Mexico, site . . . . . . . . . . . . . . . . . .

7.1 Comparison of estimated plant concentrations to phytotoxic concentrations, Shiprock, New Mexico, site . . . . . . . . . . . . . . 7 7-8

7.2 Comparison of contaminants of concern in ground water with available water quality criteria, Shiprock, New Mexico, site . . . . . . . . . 7-11

7.3 Comparison of contaminants of concern in site surface water bodies with available water quality criteria,

Shiprock, New Mexico, site

7.4 Contaminants of concern detected in sediment from site surface water bodies, Shiprock, New Mexico, site . . . . . . . . . . . . . . 7-15

7.5 Comparison of contaminants of concern in San Juan River water with available water quality criteria,

Shiprock, New Mexico, site . . . . . . . . . . . . . . . . . . .

7.6 Comparison of contaminants of concern in San Juan River sediment with available sediment quality screening levels, Shiprock, New Mexico, site . . . . . . . . . . . . . . . . . . . . .

7.7 Comparison of contaminants of concern in site surface water bodies with water concentrations protective of livestock,

Shiprock, New Mexico, site . . . . . . . . . . . . . . . . . .

8.1 Concentration limits of constituents $\ldots \ldots \ldots \ldots \ldots \ldots \ldots \ldots$ 


\section{LIST OF ACRONYMS AND ABBREVIATIONS}

Acronym

ac

$A C L$

BCF

$B \mid A$

${ }^{\circ} \mathrm{C}$

$\mathrm{cm}$

$\mathrm{cm}^{2}$

$\mathrm{cm}^{3}$

$\mathrm{cm} / \mathrm{s}$

DHHS

DOE

DW

EPA

ER-L

of

$f t$

$\mathrm{ft} / \mathrm{day}$

$\mathrm{ft}^{3} / \mathrm{s}$

FWOC

gal

$\mathrm{gal} / \mathrm{min}$

GJPO

ha

HEAST

IHS

in

IRIS

$\mathrm{Kd}$

$\mathrm{kg}$

$\mathrm{km}$

L

$\mathrm{L} / \mathrm{kg}$

$\mathrm{L} / \mathrm{min}$

LOAEL

LTSP

$\mu \mathrm{g} / \mathrm{kg}$

$\mu \mathrm{g} / \mathrm{L}$

$\mu \mathrm{mhos} / \mathrm{cm}$

$\mathrm{m}$

MCL

$\mathrm{mg} / \mathrm{g}$

$\mathrm{mg} / \mathrm{kg}$

$\mathrm{mg} / \mathrm{kg}$-day

\section{Definition}

acre

alternate concentration limit

bioconcentration factor

Bureau of Indian Affairs

degrees Celsius

centimeter

square centimeter

cubic centimeter

centimeters per second

Department of Health and Human Services

U.S. Department of Energy

dry weight

U.S. Environmental Protection Agency

effects range-low

degrees Fahrenheit

foot

feet per day

cubic feet per second

Federal Water Quality Criteria

gallon

gallons per minute

Grand Junction Projects Office

hectare

Health Effects Assessment Summary Tables

Indian Health Service

inch

Integrated Risk Information System

soil-water distribution coefficient

kilogram

kilometer

liter

liter per kilogram

liters per minute

lowest-observed-adverse-effect level

long-term surveillance plan

micrograms per kilogram

micrograms per liter

micro $\mu$ mhos per centimeter

meter

maximum concentration limit

milligrams per gram

milligrams per kilogram

milligrams per kilogram per day 


\title{
LIST OF ACRONYMS AND ABBREVIATIONS (Concluded)
}

\author{
Acronym \\ Definition \\ $\mathrm{mg} / \mathrm{L}$ \\ milligrams per liter \\ $\mathrm{mi}$ \\ mile \\ $\mathrm{mL}$ \\ milliliter \\ $\mathrm{mm}$ \\ $\mathrm{m}^{3} / \mathrm{s}$ \\ millimeter \\ MSL \\ cubic meters per second \\ mean sea level \\ NECA \\ Navajo Engineering and Construction Authority \\ NOAA \\ National Oceanic and Atmospheric Administration \\ NOAEL \\ no-observed-adverse-effect level \\ NRC \\ NTUA \\ $\mathrm{pCi} / \mathrm{L}$ \\ PEIS \\ U.S. Nuclear Regulatory Commission \\ Navajo Tribal Utility Authority \\ picocuries per liter \\ RDA \\ $R f D$ \\ programmatic environmental impact statement \\ recommended daily allowance \\ SAR \\ SOP \\ SOC \\ TDS \\ reference dose \\ sodium adsorption ratio \\ standard operating procedure \\ sediment quality criterion \\ total dissolved solids \\ UCL \\ upper confidence limit \\ UMTRA \\ Uranium Mill Tailings Remedial Action \\ UMTRCA \\ USGS \\ Uranium Mill Tailings Radiation Control Act \\ U.S. Geological Survey
}




\subsection{INTRODUCTION}

The purpose of this baseline risk assessment is to determine whether the ground water contamination at the Shiprock, New Mexico, uranium mill tailings site could adversely affect public health or the environment. The Shiprock site is one of 24 abandoned uranium mill tailings sites that are undergoing remediation in accordance with the requirements of the Uranium Mill Tailings Radiation Control Act (UMTRCA) of 1978 (42 USC 7901 et seq.). The remediation is being performed under the oversight of the U.S. Department of Energy (DOE) Uranium Mill Tailings Remedial Action (UMTRA) Project.

Under the UMTRA Surface Project, the DOE is stabilizing tailings in disposal cells that minimize radon and other radiation emissions and minimize further contamination of ground water. Remedial action at Shiprock was completed in 1986 with stabilization of the tailings at the former uranium mill site.

Under the UMTRA Ground Water Project, the DOE will evaluate ground water contamination at the sites, determine whether any action is necessary, and implement the remedial action. The DOE was authorized to perform ground water restoration in the 1988 amendments to the UMTRCA.

The strategy to evaluate and methods to clean up contaminated ground water at the UMTRA Project sites will be described in a programmatic environmental impact statement (PEIS) for ground water contamination at UMTRA Project sites, currently in preparation. This baseline risk assessment has been prepared to evaluate potential health and environmental risks and provide information to assist in determining what remedial actions are necessary. Following the PEIS and risk assessment, a site-specific environmental assessment will be prepared to evaluate and select remedial action for the Shiprock site.

This first assessment of surface water and ground water-related risks is based on available surface water and ground water data. When this data base is insufficient to adequately evaluate risks, critical data gaps will be identified. Because for most UMTRA Project sites this is the first look at risks from site-related contamination of ground water, only the major exposure pathways are evaluated here. If future decisions or actions at this site cause the primary pathway to change, minor pathways will be evaluated in more detail at that time.

This risk assessment follows the basic approach outlined by the U.S. Environmental Protection Agency (EPA) for evaluating hazardous waste sites in order to assess potential health and environmental impacts. The baseline risk assessment consists of the following steps:

- Data evaluation.

- Combining data from various site investigations.

- Comparing sample results with background and tailings source data.

- Selecting chemical data for use in the risk assessment. 
- Exposure assessment.

- Characterizing the exposure setting.

- Identifying exposure pathways.

- Quantifying exposure.

- Toxicity assessment.

- Identifying toxicity values.

- Evaluating noncarcinogenic effects.

- Evaluating carcinogenic effects from radionuclides and chemical carcinogens.

- Public health risk characterization.

- Comparing toxicity ranges to predicted exposure ranges.

- Combining risks across exposure pathways and multiple contaminants.

- Characterizing uncertainties.

- Environmental risk.

- Characterizing potential biota exposure pathways.

- Identifying potential ecological receptors.

- Evaluating environmental risk qualitatively.

This approach is used to estimate risks from potential current and future use of contaminated ground water or surface water near the site. 


\subsection{SITE DESCRIPTION}

The Shiprock site is on the Navajo Indian reservation, 1 mile (mi) (1.6 kilometers [km]) south of the town of Shiprock, San Juan County, in northwestern New Mexico. It lies on the southwest bank of the San Juan River. Farmington, New Mexico, is approximately 30 $\mathrm{mi}(50 \mathrm{~km})$ east of the Shiprock site (Figure 2.1).

\subsection{SITE BACKGROUND}

The former Navajo Mill at the Shiprock site was constructed and operated from 1954 to 1963 by Kerr-McGee Oil Industries, Inc., and from 1963 to 1968 by Vanadium Corporation of America and its successor, Foote Mineral Company. Before and during the milling operations, the site was leased from the Navajo Nation. When the lease expired in 1973, ownership of the site reverted to the Navajo Nation.

The mill reportedly processed approximately 1.5 million short tons 11.4 million metric tons) of ore along with smaller quantities of bulk precipitates from heap leach operations from the Monument Valley area and frcm purchased vanadium liquor (DOE, 1985). Ore processing consisted of crushing, leaching with sulfuric acid, washing, and extracting uranium and vanadium with organic solvents (di[2-ethylhexyl] phosphoric acid and tributyl phosphate in kerosene). Tailings from the washing circuit and yellow cake filtrates were pumped to tailings disposal areas. Raffinate from the solvent extraction operation was allowed to evaporate in separate unlined lagoons to the west and southeast of the tailings piles (Figure 2.2).

Between 1984 and 1986, the tailings were stabilized permanently on the site by consolidating the tailings and associated contaminated soils into a recontoured pile. The final cover at Shiprock consists of a 7-foot (ft) (2-meter [m]) thick compacted clayey layer that serves as a barrier to radon emanation and water infiltration. The riprap cap is designed to provide erosion protection for the effective life of the cell (up to 1000 years) and to act as a barrier to the intrusion of plants and animals into the infiltration/radon barrier and the stabilized tailings (DOE, 1990). The disposal cell covers about 76 acres (ac) ( 31 hectares [ha]) (Thiers, 1986). A security fence encloses the embankment.

The Shiprock site is stabilized and is in prelicensing status. The site is expected to remain in this status until licensed by the U.S. Nuclear Regulatory Commission (NRC) under the provisions of 10 CFR Part 40 (1993) for long-term surveillance and maintenance. The general license becomes effective for the Shiprock disposal site after the NRC concurs with the completion of the surface remedial action and approves the long-term surveillance plan (LTSP). Upon licensing, responsibility for conducting the long-term surveillance program for the disposal cell will be transferred from the DOE UMTRA Project Office in Albuquerque to the long-term surveillance and maintenance program at the DOE Grand Junction Projects Office (GJPO). 

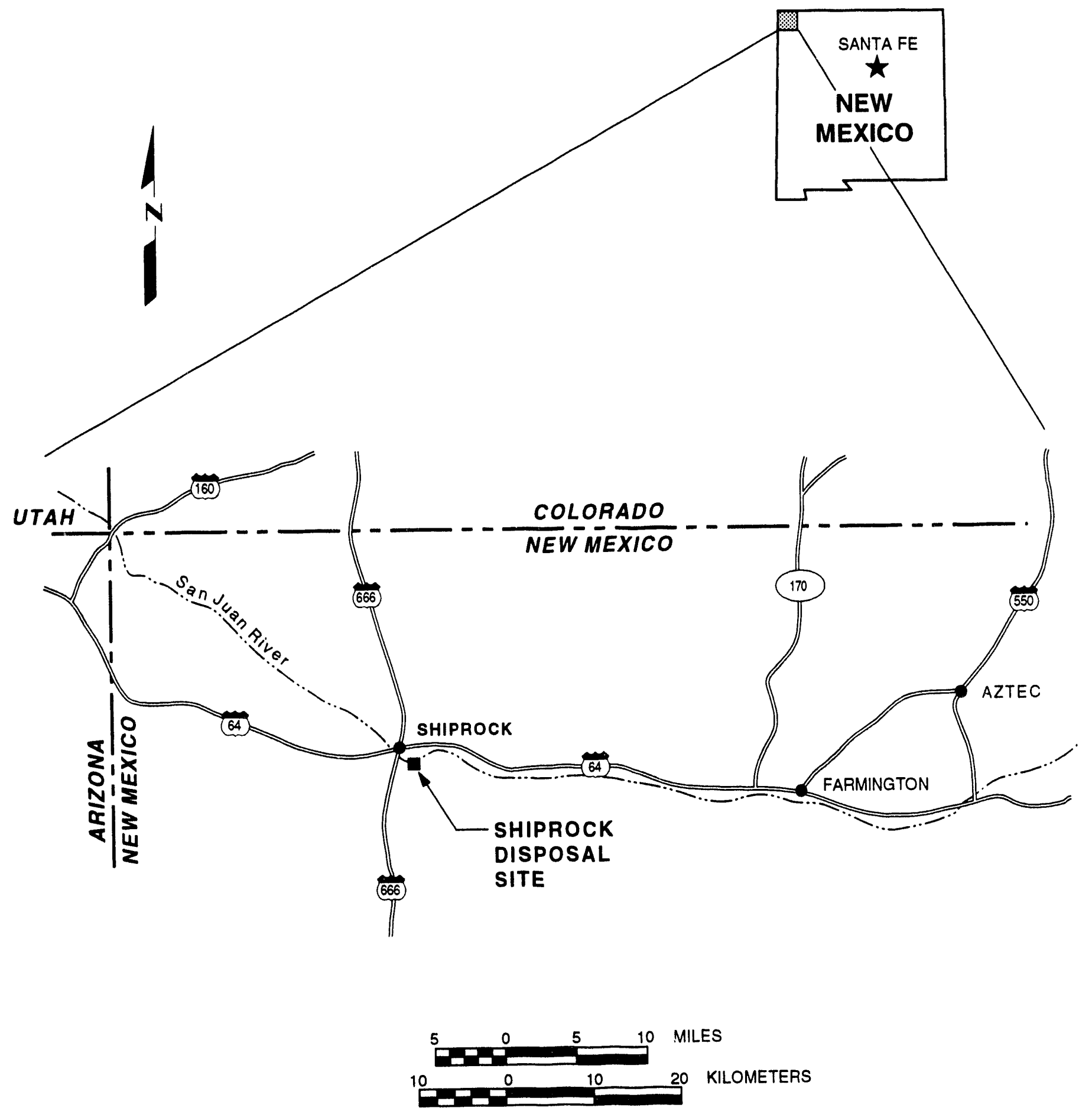

FIGURE 2.1

SHIPROCK SITE LOCATION MAP

SHIPROCK, NEW MEXICO, SITE 


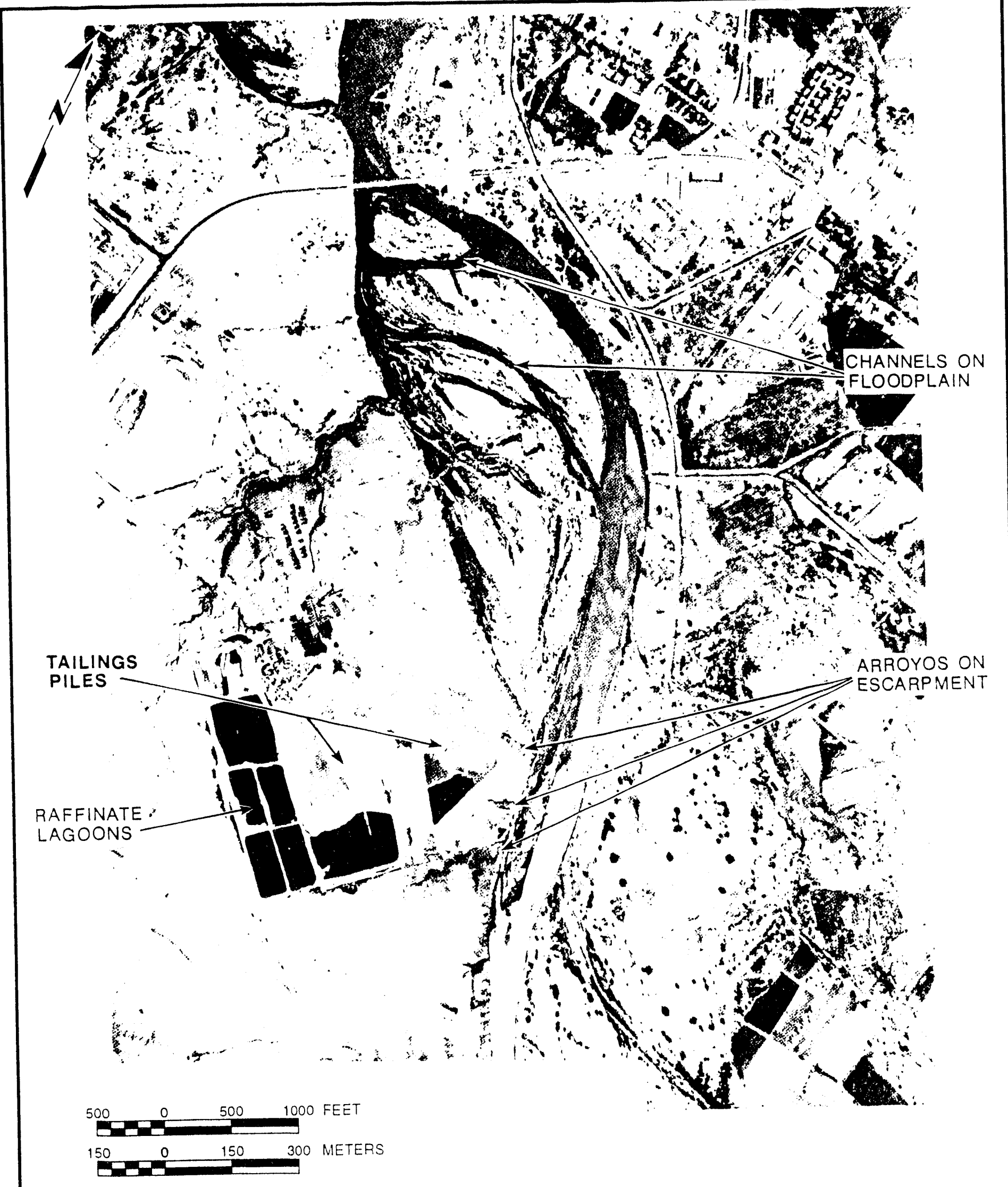

FIGURE 2.2

AERIAL VIEW OF SHIPROCK SITE IN OPERATING PERIOD SHIPROCK, NEW MEXICO, SITE 


\subsection{CLIMATE}

The climate of the Shiprock area is semiarid, with a total annual precipitation of about 6 inches (in) (15 centimeters [cm]). The wettest months are July through October, when approximately half the annual precipitation falls. The driest month is June. During the winter, snowfall is light, occurring only about 10 days per year and averaging 4 in $(10 \mathrm{~cm})$. Skies are normally clear; solar illumination and surface water evaporation are high. The average annual pan evaporation rate is 65 in $(165 \mathrm{~cm}) ; 74$ percent of the annual evaporation occurs from May through October.

Summer days are warm to hot, while summer evenings are cool. Winters are relatively mild. The annual average temperature is 52 degrees Fahrenheit $\left({ }^{\circ} \mathrm{F}\right)(11$ degrees Celsius $\left.\left[{ }^{\circ} \mathrm{C}\right]\right)$. Normal daily highs range from $42^{\circ} \mathrm{F}\left(5.5^{\circ} \mathrm{C}\right)$ in January to $94^{\circ} \mathrm{F}\left(34^{\circ} \mathrm{C}\right)$ in July, while normal daily lows range from $15^{\circ} \mathrm{F}\left(-9.4^{\circ} \mathrm{C}\right)$ in January to $58^{\circ} \mathrm{F}\left(14^{\circ} \mathrm{C}\right)$ in July. The extreme temperatures that can be expected in Shiprock range from $-26^{\circ} \mathrm{F}\left(-32^{\circ} \mathrm{C}\right)$ in December to $107^{\circ} \mathrm{F}\left(42^{\circ} \mathrm{C}\right)$ from June through August (DOE, 1984). Prevailing light winds are from the south and east quadrants. Higher prevailing winds are usually associated with frontal systems and are from the north and west.

\subsection{PHYSIOGRAPHIC SETTING}

The disposal cell is on an elevated river terrace south of the San Juan River (Figure 2.3). The site is relatively level, with natural elevation ranging from a high of approximately $4980 \mathrm{ft}(1520 \mathrm{~m})$ above mean sea level (MSL) along the southwestern edge of the property to a low of about $4950 \mathrm{ft}(1510 \mathrm{~m})$ along the top of a $50-\mathrm{ft}(15-\mathrm{m})$ high, northwest-southeast trending escarpment, separating the elevated terrace from the modern floodplain of the San Juan River. South of the site, the terrace continues gently upward for approximately $2500 \mathrm{ft}(760 \mathrm{~m})$ where it meets the weathered and colluvial covered bedrock uplands.

The modern floodplain of the San Juan River is located at the base of the escarpment north of the disposal cell. It begins approximately $1000 \mathrm{ft}(300 \mathrm{~m})$ upstream of the northeast corner of the site, widens to a maximum width of about $1500 \mathrm{ft}(460 \mathrm{~m})$, then pinches out against the bedrock escarpment at the bridge supporting Route 666 over the San Juan River, approximately $2200 \mathrm{ft}(670 \mathrm{~m})$ downstream of the northwestern corner of the site.

Two arroyos are located east and west of the tailings site. Bob Lee Wash is an arroyo bordering the western side of the site. Many Devils Wash parallels Bob Lee Wash approximately $2500 \mathrm{ft}(760 \mathrm{~m})$ southeast of the site. 


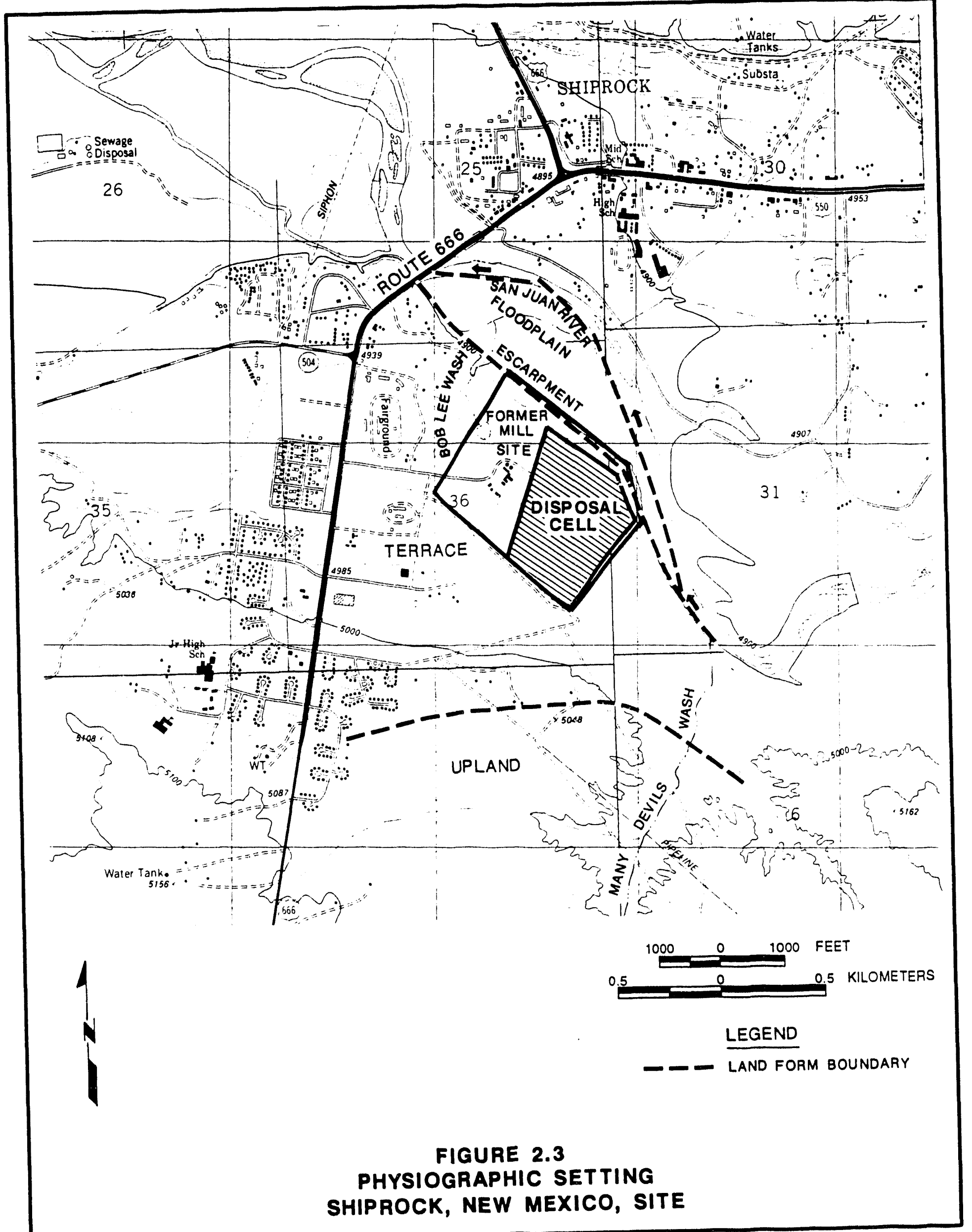




\subsection{HYDROGEOLOGY}

Four hydrogeologic units are relevant to the Shiprock baseline risk assessment: the terrace alluvium, the floodplain alluvium, the Mancos Shale, and the deep, confined bedrock aquifers (Dakota Sandstone and Morrison Formation).

The disposal cell foundation rests on approximately 10 to $45 \mathrm{ft}(3$ to $13 \mathrm{~m})$ of terrace alluvium. This alluvium consists of interbedded sands and silts with numerous lenses of gravel and cobbles.

The terrace deposit is underlain by Mancos Shale consisting of flat-lying beds of shales and sandy shales. In the Shiprock area, the Mancos Shale is approximately $1000 \mathrm{ft}(300 \mathrm{~m})$ thick (McLean and Johnson, 1987). The upper 10 to $30 \mathrm{ft}(3$ to $9 \mathrm{~m}$ ) of the Mancos Shale is highly weathered, exhibiting fractures, fissility, and low strength. Below the highly weathered zone, the shale is more competent and relatively impermeable. Beneath the Mancos Shale are the Dakota Sandstone and the Morrison Formation.

North of the disposal cell is the floodplain of the San Juan River. The floodplain alluvium consists of unconsolidated, interbedded boulders, cobbles, gravels, sands, silts, and clays. The Maricos Shale underlies the floodplain alluvium at an average depth of approximately $15 \mathrm{ft}(5 \mathrm{~m})$. The alluvium within the floodplain is separated from the terrace deposit beneath the disposal cell by a $50-\mathrm{ft}(15-\mathrm{m})$ high vertical cliff. Mancos Shale is exposed in the lower two-thirds of the cliff.

\subsubsection{Terrace hydrology}

Ground water below the disposal site on the terrace occurs in the alluvium; in the upper, weathered part of the Mancos Shale; and in the Dakota Sandstone and Morrison Formation. Some ground water may also occur in fractures or sandstone tongues in the unweathered Mancos Shale, but the extent of these occurrences has not been determined. The ground water in the alluvium and the upper part of the Mancos Shale is unconfined and constitutes the uppermost aquifer. Ground water in the Dakota Sandstone and Morrison Formation is confined. A flowing well near the site is reportedly completed in the Morrison Formation from approximately 1500 to $1900 \mathrm{ft}(450$ to $570 \mathrm{~m})$ below land surface (McLean and Johnson, 1987). The free flowing condition demonstrates that the piezometric surface in the Morrison Formation is higher than the water table in the alluvium or the upper part of the Mancos. This higher head, combined with the low permeability of the unweathered Mancos Shale, will preclude movement of impacted water beneath the tailings pile into the deeper aquifers.

The terrace alluvium is recharged by precipitation, and in the vicinity of the site probably still contains water discharged from the former milling operations and tailings pile. The numerous lagoons active during the milling operations, as shown on Figure 2.2, reportedly lost as much as 4.9 million gallons (gal) (19 million liters [L]) per month. This amount of water in such a dry climate could have formed a considerable ground water mound perched on the Mancos Shale. Infiltrating 
seepage would move across the shale surface in all directions and infiltrate the upper, weathered zone of the shale. As the size of the mound diminished after the milling operations ceased, the movement of the perched ground water would be controlled by the topography of the Mancos Shale.

Historically, the San Juan River meandered across the terrace surface. Monitor wells show that remnant erosional swales and low ridges exist on the top of the eroded surface of the Mancos Shale (Figure 2.41. These ridges and swales could cause the perched ground water to flow west-northwest in addition to flowing toward the present San Juan River, as would normally be anticipated. To date, there are not enough data to develop an accurate flow map of the ground water in the terrace alluvium.

Monitor wells installed to bracket the alluvial/bedrock interface and test pits that were excavated into the weathered shale indicate that only a relatively thin layer of water is perched on the bedrock. This perched ground water represents a very limited resource for future development.

The ground water in the alluvium also percolates down into the upper, fractured part of the Mancos Shale. Some of this water moves horizontally along bedding planes and can be seen seeping from bedding planes in the shale along the escarpment face immediately north of the disposal site. It is also anticipated that ground water in the deeper Mancos may flow toward the San Juan River, the local base level in the region. This water would then move up out of the Mancos into the alluvium of the floodplain (Figure 2.5).

\subsubsection{Floodplain hydrology}

The floodplain alluvium contains a shallow ground water system. It is recharged primarily by water from the San Juan River that enters the floodplain at its upstream end, approximately $1000 \mathrm{ft}(300 \mathrm{~m})$ east of the tailings pile. Additional recharge comes from the flowing well at Bob Lee Wash and from the seeps along the escarpment. The floodplain alluvium is also the local discharge zone for the underlying Mancos Shale. The ground water in the floodplain then discharges back to the river along the downstream half of the floodplain. A water table map of the floodplain is shown in Figure 2.6.

Some ground water in the floodplain enters a drainage ditch that separates the northwestern third of the floodplain (Figure 2.6). This ditch follows a preexisting natural meander channel in the floodplain (see Figure 2.2) but appears to have been artificially deepened. During periods of high water flow, the water table intersects this canal. Some ground water flow is diverted into the ditch, which discharges to the river at the extreme northwestern end of the floodplain. During low water periods, however, the water table is beneath the bottom of the ditch, and this channel will not affect the movement of the ground water.

The ground water within the floodplain on the north side of the San Juan River enters at the upstream end and discharges along the downstream portion. This 


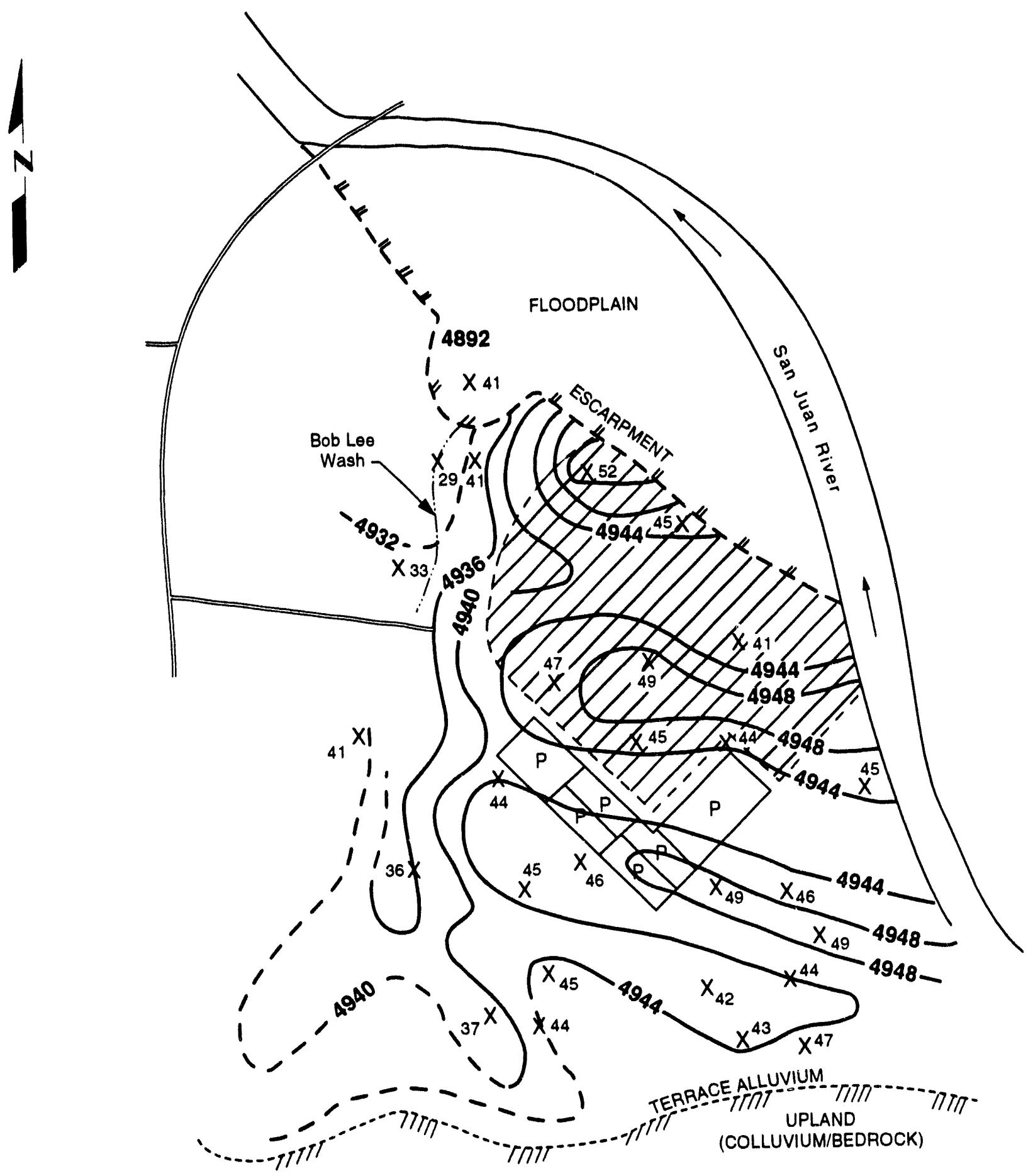

\section{LEGEND}

-4892 - BEDROCK SURFACE CONTOUR

${ }^{41} \mathrm{X}$ BEDROCK ELEVATION IN

WD former taILINGS PILES AND MILLSITE

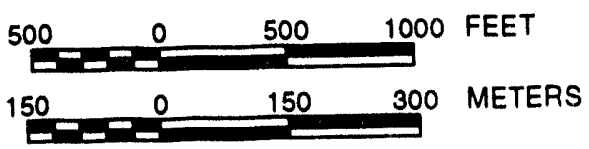

$P$ FORMER RAFFINATE POND

FIGURE 2.4

BEDROCK SURFACE CONTOURS ON TERRACE SHIPROCK, NEW MEXICO, SITE 
A

SOUTH

NORTH

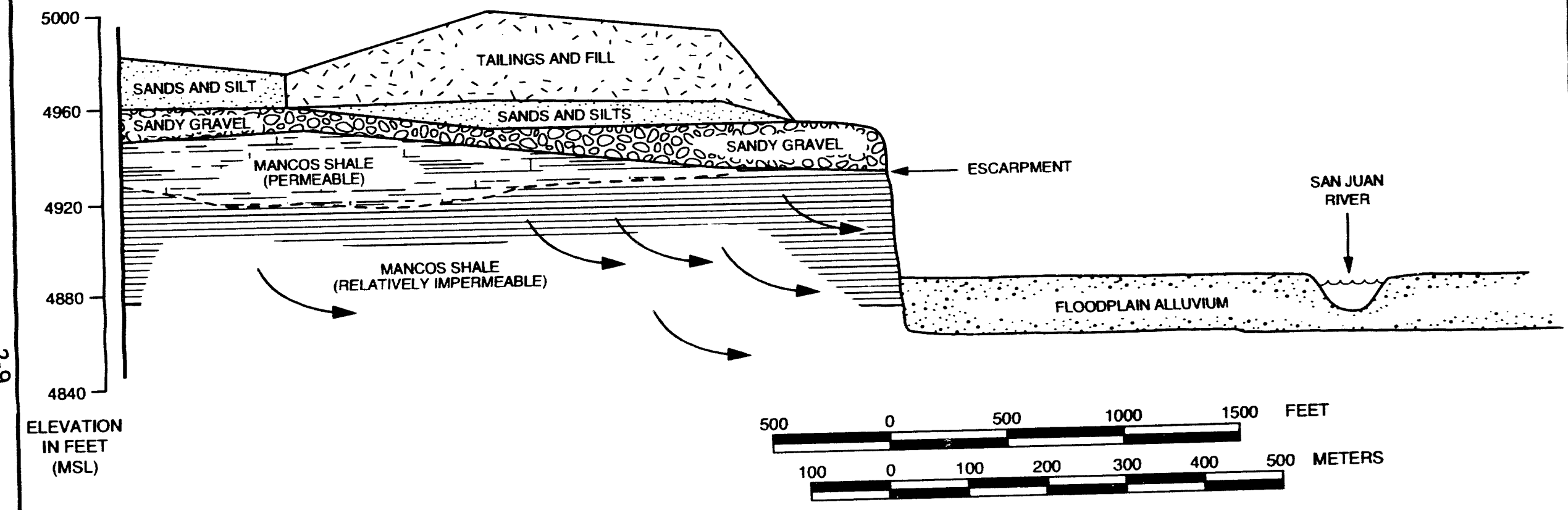

\section{LEGEND}

DIRECTION OF GROUND WATER FLOW

THROUGH MANCOS SHALE
NOTE: SEE FIGURE 2.7 FOR LOCATION OF CROSS SECTION MODIFIED FROM DOE, 1991

FIGURE 2.5

CROSS SECTION A-A'

SHIPROCK, NEW MEXICO, SITE 


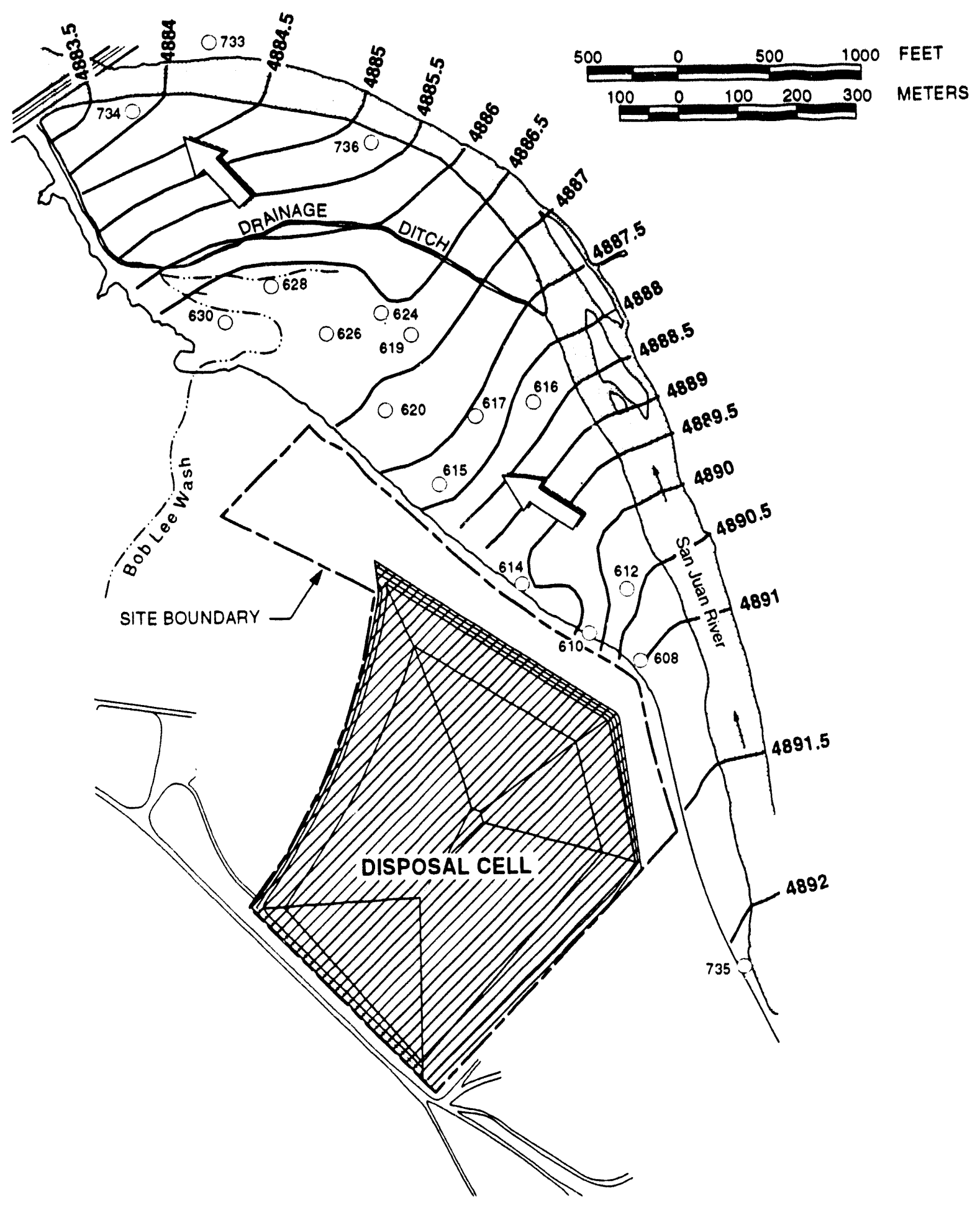

\section{LEGEND}

O735 MONITOR WELL

$$
\begin{aligned}
& 4887-\begin{array}{l}
\text { GROUND WATER ELEVATION APRIL } 1993 \\
(0.5-F T \text { CONTOURS) }
\end{array} \\
& \text { GROUND WATER FLOW DIRECTION }
\end{aligned}
$$

FIGURE 2.6

GROUND WATER CONTOURS ON FLOODPLAIN SHIPROCK, NEW MEXICO, SITE 
floodplain also probably receives recharge from the upland areas farther to the north. The water table elevations on the opposite sides of the river will preclude the movement of ground water from one side of the river to the other. All water will eventually discharge to the San Juan River or the channel fill. Therefore, tailings leachate within the floodplain alluvium will not migrate beneath the San Juan River.

The stratigraphy of the floodplain is extremely variable, both horizontally and vertically. The fluvial deposits are typical of floodplains in such environments; they vary from coarse gravel and cobbles found in high-energy channels to fine, uniform sands indicative of point bars to silty sediments typical of quiet backwater areas. This heterogeneity means there is no one value of hydraulic conductivity representative of the entire floodplain.

Visual inspection of the sediments and comparisons with typical ranges described in the literature (Hunt, 1984) suggests that the hydraulic conductivity could vary by 2 orders of magnitude, from less than 5 feet per day ( $\mathrm{ft} / \mathrm{day})(0.001$ centimeters per second $[\mathrm{cm} / \mathrm{s}])$ to more than $300 \mathrm{ft} / \mathrm{day}(0.1 \mathrm{~cm} / \mathrm{s})$. The sediments encountered during installation of monitor wells 734 and 736 (see Figure 2.7), where ground water discharges from the floodplain into the San Juan River, were relatively uniform, medium-grained sands. Because the conductivity of these sediments will control the discharge rate of impacted water to the San Juan River, an intermediate hydraulic conductivity typical of such sediments (approximately $30 \mathrm{ft} /$ day 10.01 $\mathrm{cm} / \mathrm{s}$ ]) will be used in this study.

The hydraulic gradient also varies across the floodplain, ranging from 0.001 to 0.002 . A hydraulic gradient of 0.002 was calculated for the area of discharge and is used in this study.

A calculation based on a hydraulic conductivity of $30 \mathrm{ft} /$ day $(0.01 \mathrm{~cm} / \mathrm{s})$, a hydraulic gradient of 0.002 , and an assumed cross-sectional area of discharge along the southern bank of the San Juan River $8 \mathrm{ft}(2.4 \mathrm{~m})$ deep and $2500 \mathrm{ft}$ $(750 \mathrm{~m})$ long results in an average ground water discharge of 0.015 cubic feet per second $\left(\mathrm{ft}^{3} / \mathrm{s}\right)\left(0.00045\right.$ cubic meters per second $\left[\mathrm{m}^{3} / \mathrm{sec}\right)$ ).

\subsection{SURFACE WATER}

The San Juan River forms the eastern and northern boundaries of the floodplain north of and below the disposal cell. Surface runoff south and west of the site flows east and north into Bob Lee Wash. Bob Lee Wash also receives a constant discharge of approximately $480 \mathrm{ft}^{3} / \mathrm{s}\left(15 \mathrm{~m}^{3} / \mathrm{sec}\right.$ ) from an artesian well located west of the wash (see well 648 in Figure 2.7). Discharge from this well flows down Bob Lee Wash and discharges into a swampy area on the floodplain. This water eventually flows into a drainage swale that cuts across the floodplain and joins the San Juan River approximately $0.5 \mathrm{mi}(0.8 \mathrm{~km})$ northwest of the disposal cell. Surface runoff east of the tailings pile either flows into a borrow area east of the site and then down the escarpment onto the floodplain or it reaches Many 


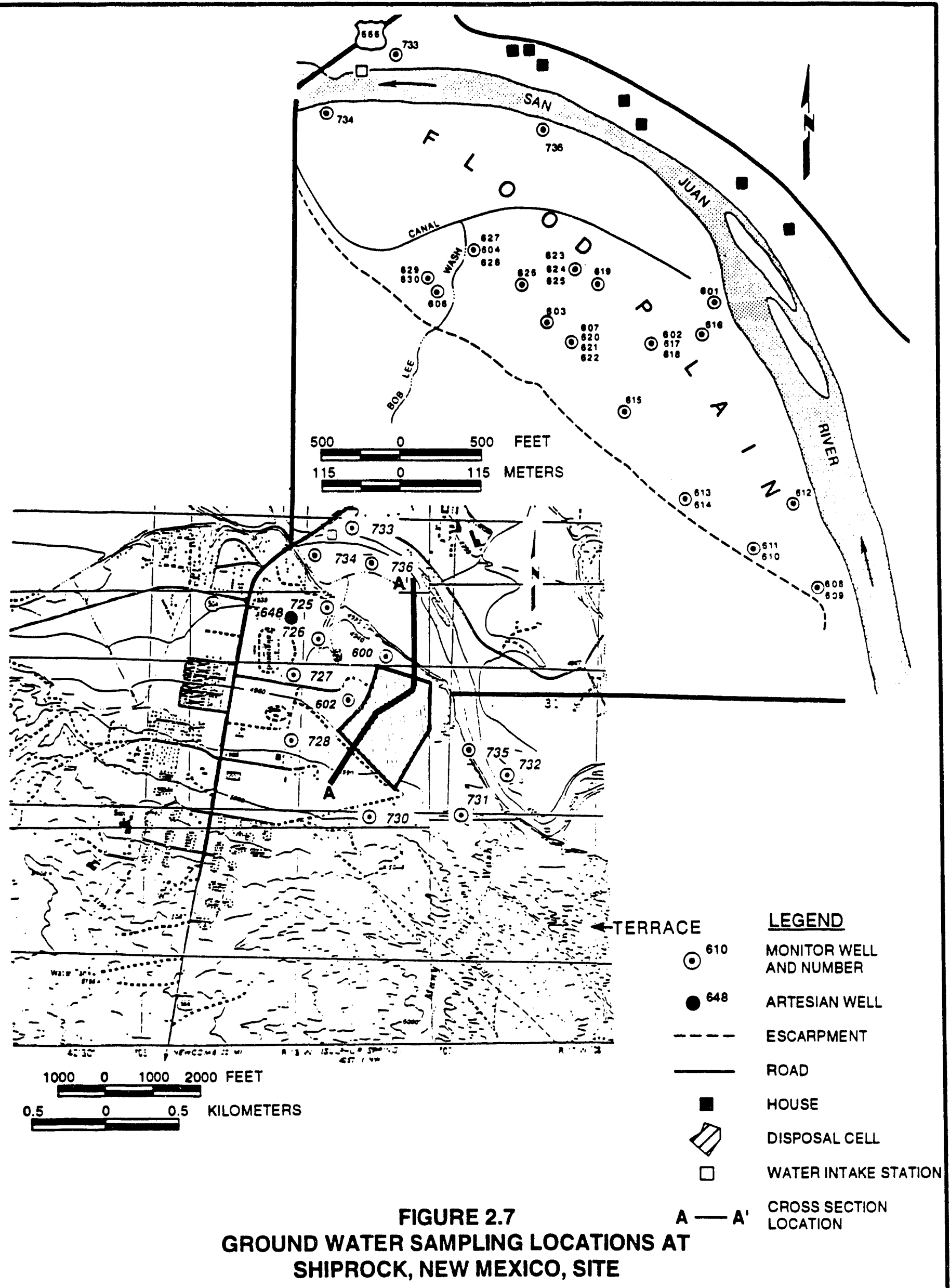


Devils Wash, which discharges into the San Juan River approximately $0.5 \mathrm{mi} 10.8$ $\mathrm{km}$ ) east of the cell.

Three unnamed arroyos that cut the escarpment above the floodplain can be seen in the aerial photograph in Figure 2.2, which was taken before site cleanup. These arroyos were filled during the surface restoration activities at the site. According to a 1977 letter report (Hans, 1977), seeps were identified and sampled in these arroyos.

In 1990, two seeps were identified originating from the escarpment of Mancos Shale that rises from the San Juan River floodplain (Figure 2.8). One seep is located on the escarpment about $15 \mathrm{ft}(5 \mathrm{~m})$ above the floodplain near the northwest corner of the disposal cell. This seep is about $30 \mathrm{ft}(9 \mathrm{~m})$ long and consists of a series of drips under an overhanging, indurated sand lens within the Mancos Shale. The flow rate from the seepage face was approximately $0.5 \mathrm{gal} / \mathrm{min}$ $(2 \mathrm{~L} / \mathrm{min})$ in January 1991. The second seep is located Immediately south of where Bob Lee Wash enters the San Juan River floodplain. This seep is approximately $5 \mathrm{ft}$ $(2 \mathrm{~m})$ above the floodplain and flowed at a rate of about $1 \mathrm{gal} / \mathrm{min}(4 \mathrm{~L} / \mathrm{min})$ in January 1991.

\subsection{LAND USE}

The Shiprock site is on the Navajo Indian reservation adjacent to the unincorporated town of Shiprock. Figure 2.9 shows the land uses in the vicinity of the site.

According to unofficial estimates of Shiprock's population in 1980 (FBDU, 1981), 90 people lived within $0.5 \mathrm{mi}(0.8 \mathrm{~km})$ of the site and 2200 within $1 \mathrm{mi}(1.6 \mathrm{~km})$. In 1983, the population of Shiprock was estimated at 8000 .

A mix of residential and commercial development exists near the site. A U.S. Public Health Service building, Navajo Engineering and Construction Authority (NECA) facilities, Abandoned Mine Land Program office buildings, and fairgrounds are immediately west of the former mill site. West of U.S. Highway 666 is a residential area with a day care center and community development offices.

Approximately 80 people lincluding 30 children 15 years of age and younger/ live in a residential area west of Bob Lee Wash (TAC, 1993). This community consists of approximately 15 households, with an average of five persons per household. A hogan in this community is used for ceremonial purposes only. Most residents have lived at the present location for at least 10 years. Many of them raise livestock such as horses, cows, sheep, donkeys, rabbits, ducks, and chickens. These animals graze near Bob Lee Wash and may also graze in the San Juan River floodplain. Only a few residents keep vegetable gardens.

Approximately 10 households are located southwest of the disposal site, with an average of four persons per household. This community consists of approximately 40 persons, including 14 children. Most of these residents have lived at the 

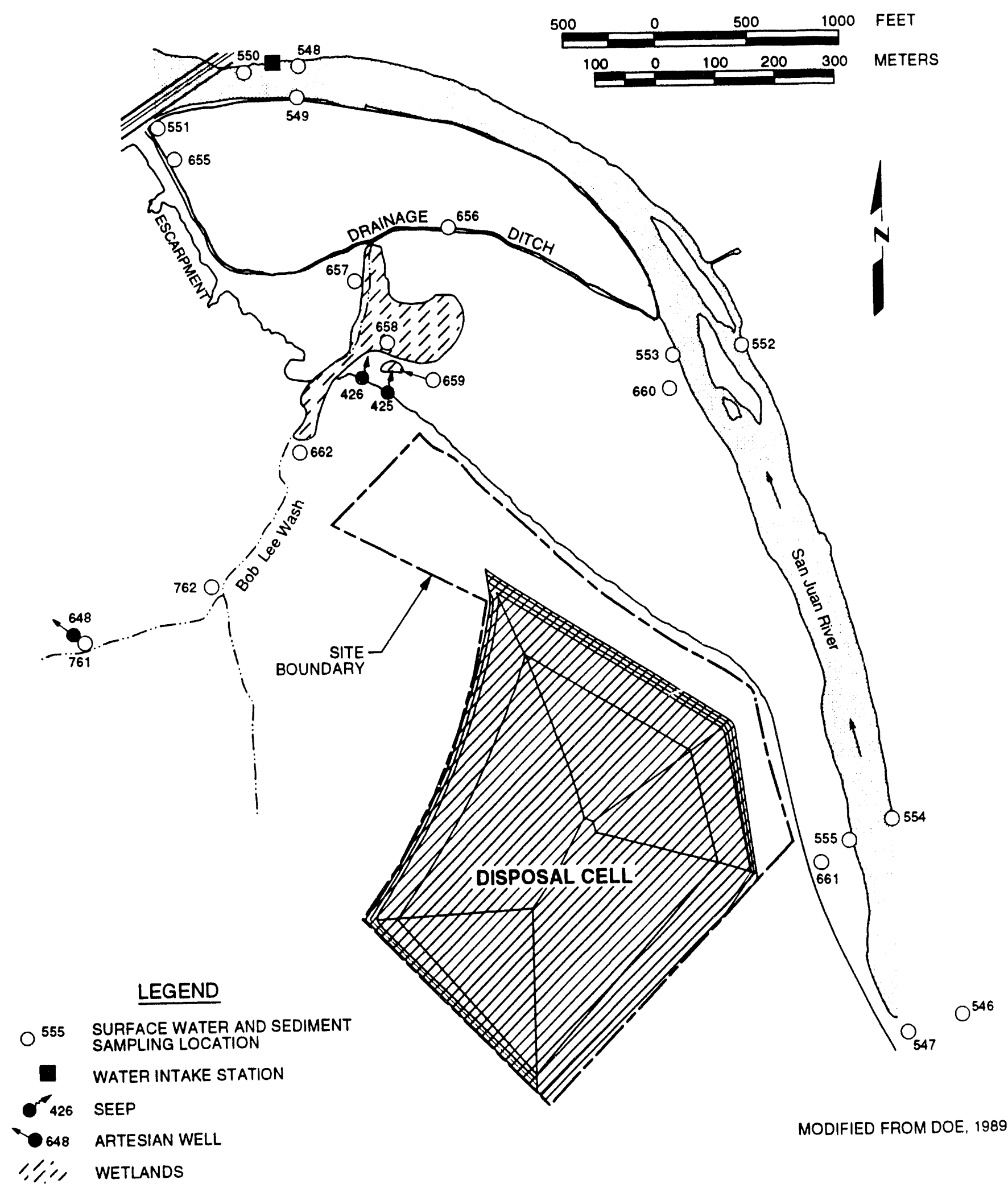

MODIFIED FROM DOE, 1989

NOTE: SAMPLING LOCATIONS 547, 546 ARE LOCATED 500 METERS SOUTHEAST FROM LOCATIONS 554 AND 555

FIGURE 2.8

LOCATIONS OF FLOODPLAIN SURFACE WATER AND SEDIMENT SAMPLING STATIONS ADJACENT TO SHIPROCK TAILINGS SITE SHIPROCK, NEW MEXICO 


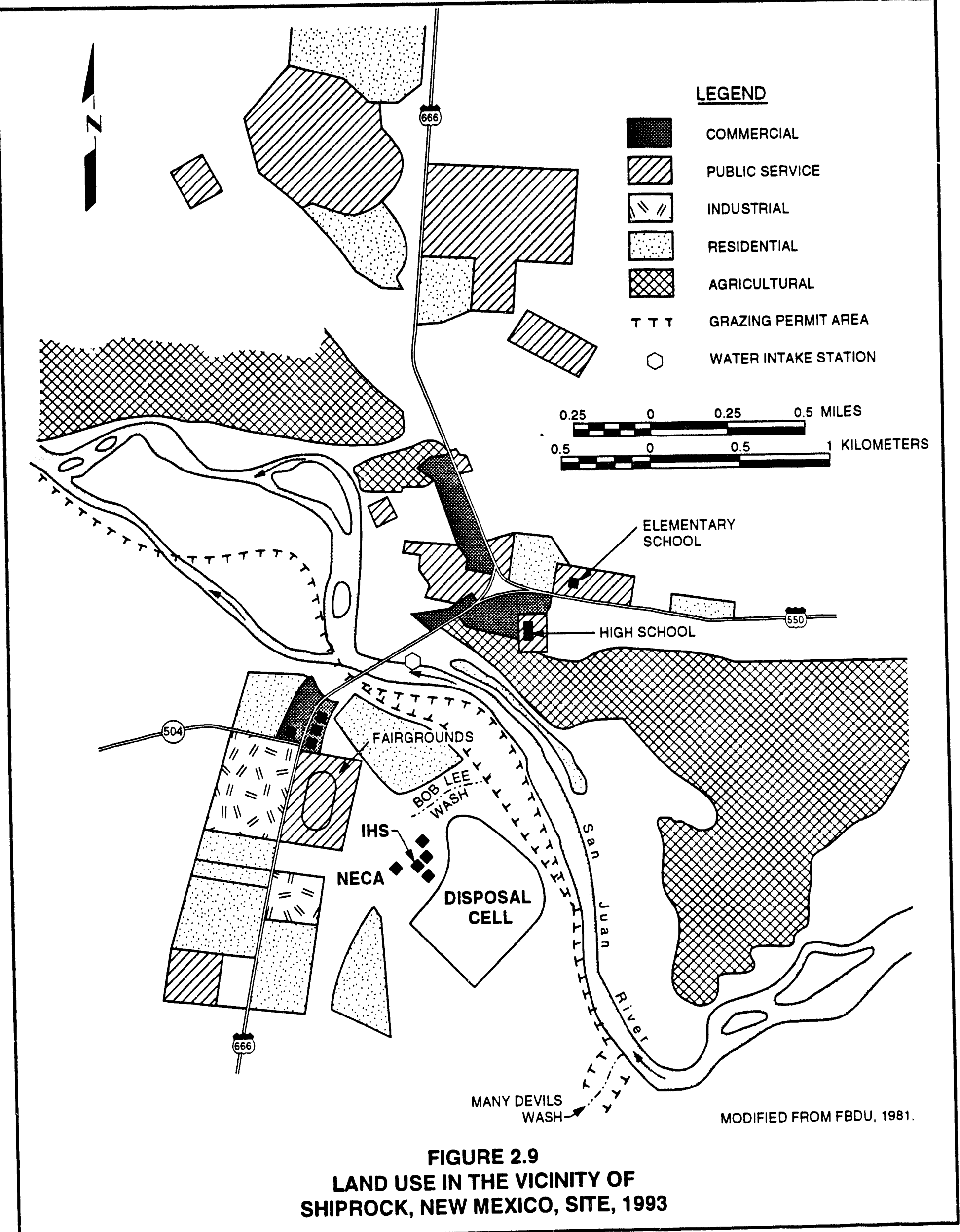


present location for 18 years. Very few of them raise domestic animals such as chickens and they do not have vegetable gardens.

Individual members of the Navajo Nation do not literally own land; rather, land use rights are maintained by several systems of land tenure. The Navajo system for land assignment consists of grazing permits. The grazing permit system was developed in the 1940s to assign land based on sheep units. A Navajo cannot establish a residence without a grazing permit, which is generally passed down or subdivided for family members. The Bureau of Indian Affairs (BIA) Land Operations office oversees permit registration. As shown in Figure 2.9, a grazing permit has been issued for the floodplain beneath the site.

For several miles upstream and downstream from the site, the San Juan River floodplain is used for irrigated farming and low-density grazing. The irrigated farm land is used mainly to produce hay for feeding livestock. The floodplain also provides habitat for indigenous wildlife and migrating birds.

\subsection{WATER USE}

A field search and inquiries in 1993 did not identify any domestic or other wells within or near the residential area northwest of the site. Treated San Juan River water is provided to these residents by the Navajo Tribal Utility Authority (NTUA) (Charley, 1993).

Residences west of Bob Lee Wash and southwest of the disposal site are also connected to the NTUA Shiprock municipal water supply system. Water from the artesian well (see well 648 in Figure 2.7) is the primary source of water for livestock kept at residences west of Bob Lee Wash, as well as for watering gardens. However, animals also may consume surface water from the floodplain and Bob Lee Wash.

The on-site NECA facilities, Public Health Service building, and Abandoned Mine Land Program buildings are connected to the municipal water and sewer systems.

The Shiprock community water system obtains water from the San Juan River at two locations. One intake is in the San Juan River approximately $8 \mathrm{mi}(13 \mathrm{~km})$ upstream (east) of the town (DOE, 1984; NTUA, 1993). This intake is used as a source of water from April to October. It is capable of providing water year-round, though the NTUA does not have permission to withdraw year-round at this location. The primary water intake for NTUA in winter is approximately $300 \mathrm{ft}(90 \mathrm{~m})$ upstream of the Route 666 bridge over the river. This latter intake, built around 1978 , is on the north side of the San Juan River across the river from the site. Pumps for this intake are installed $15 \mathrm{ft}(5 \mathrm{~m})$ below the river surface. A pipeline connection with the Farmington community water system provides a backup system for Shiprock.

Surface water supplies from the San Juan River are treated at NTUA's water treatment plant, which has a design capacity of 3 million gal/day $(11$ million L/day). 
In 1991, NTUA's plant treated approximately 200 million gal (800 million L) of water, with an average of 10 to 27 million gal (38 to 102 million L) per month. Approximately 30 percent of this amount originated from the water intake near the former mill site. In 1992, 280 million gal (1 billion L) of water were treated at the plant (NTUA, 1993). The water treatment process consists of three stages: sedimentation (clarification and flocculation with aluminum sulfate and polymer), sand filtration, and treatment with chlorine.

The NTUA's water supply system provides potable water to Shiprock. It is also a water source for industrial and agricultural uses. In 1983, the NTUA provided service to more than 1300 residences and 100 commercial or institutional establishments. 


\subsection{EXTENT OF CONTAMINATION}

Water quality data were collected from 1984 to 1993 at most existing monitor wells and surface locations at Shiprock. At present, 8 monitor wells are on the terrace and 51 monitor wells are on the north and south floodplains. Eight surface water locations are currently monitored or have been sampled in the past. Water quality samples have also been collected from a well (648) west of Bob Lee Wash that is completed in the regional aquifer (Morrison Formation). Monitor wells and surface sampling locations are shown in Figures 2.7 and 2.8 .

Filtered groundwater samples were collected and analyzed from several locations on the alluvial floodplain. Water samples were collected following applicable standard operating procedures (SOP), Section 16 of the Albuquerque Operations Manual (JEG, n.d.). Both filtered and unfiltered samples were collected and analyzed from several locations on the terrace alluvium. Data from unfiltered surface water samples that were collected and analyzed from the San Juan River in 1993 are used in this risk assessment.

\subsection{BACKGROUND WATER QUALITY SUMMARY}

Background water quality is defined as the quality of water if uranium milling activities had not taken place. Because there are two distinct shallow hydrologic systems at the Shiprock site, the terrace alluvium and the alluvial floodplain, it is necessary to determine background water quality for each hydrologic system.

\subsubsection{Terrace alluvium}

There are currently no background water quality data for the terrace alluvium and the areal and vertical extent of influence from milling activities is not fully characterized. Therefore, the impact from the uranium milling process can be described only generally. Additionally, it is not known if the terrace alluvium ground water represents a sustainable water resource.

\subsubsection{Floodplain}

Ground water in the floodplain below the terrace has been degraded by milling activities. Therefore, data from this ground water cannot be used to determine background. Instead, background water quality data were taken from wells completed in the alluvial system north of the San Juan River. Wells used in the qualitative and quantitative background analysis are listed in Table 3.1. The locations of background wells are shown in Figure 3.1.

Monitor wells 732 and 733 and domestic wells 634 and 635 were used in the quantitative statistical background analysis. Water quality data from two U.S. Geological Survey (USGS) locations (SJ3, approximately $9 \mathrm{mi}[14 \mathrm{~km}$ ] upstream and $\mathrm{G} 10$, approximately $8 \mathrm{mi}[13 \mathrm{~km}]$ downstream from the site) (see Figure 3.1) were used to compare ground water quality in the shallow alluvial system above and below the Shiprock site. 


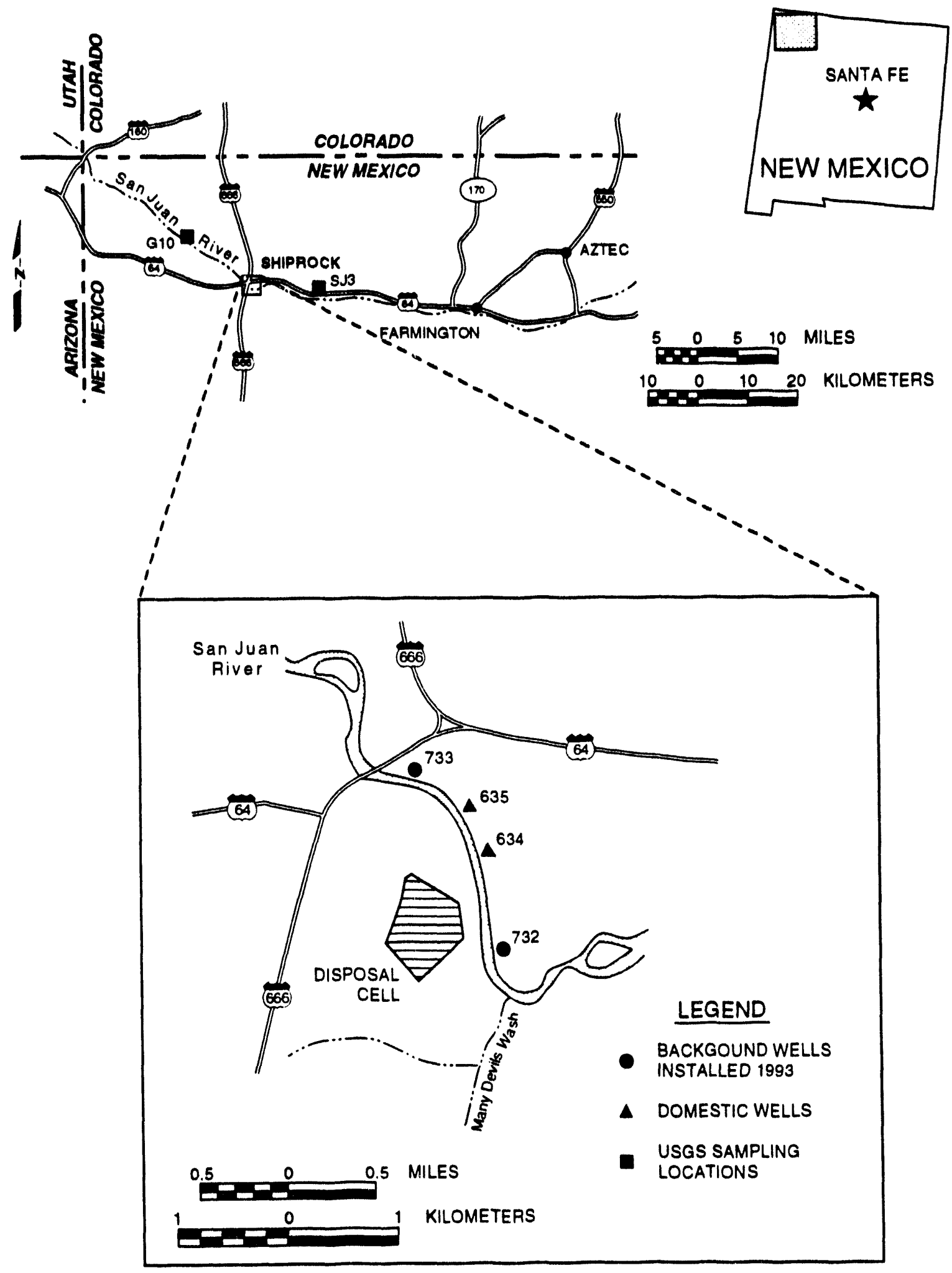

FIGURE 3.1

BACKGROINND WELLS USED FOR QUALITATIVE (SJ3, G10) AND QUANTITATIVE $(732,733,634,635)$ ANALYSIS OF GROUND WATER IN THE ALLUVIAL AQUIFER SHIPROCK, NEW MEXICO, SITE 
Table 3.1 Wells used to determine background water quality

\begin{tabular}{ccc}
\hline \multicolumn{1}{c}{ Location } & \multicolumn{2}{c}{$\begin{array}{c}\text { Screened interval } \\
\text { (depth below surface) }\end{array}$} \\
\cline { 3 - 4 } Background wells installed 02/93 & \multicolumn{1}{c}{$(\mathrm{ft})$} & $(\mathrm{m})$ \\
$732 \quad$ Downstream & $7-17$ & $2.1-5.2$ \\
$733 \quad$ Across river from floodplain & $6.5-11.5$ & $2.0-3.5$ \\
Domestic wells across from the floodplain & & $?-7$ \\
$634 \quad$ Across river from floodplain & $?-24$ & $?-4$ \\
$635 \quad$ Across river from floodplain & $?-12$ & $1.5-3.0$ \\
USGS sampling locations & & NA \\
SJ3 Well, upstream by Hogback & $5-10$ & NA \\
G10 Seep, downstream by Cudei &
\end{tabular}

NA - not available.

Background ground water can be described as a sulfate-bicarbonate, calciumsodium type with slightly basic $\mathrm{pH}$ and total dissolved solids (TDS) ranging from 800 to 5000 milligrams per liter $(\mathrm{mg} / \mathrm{L})$. Background ground water from the six locations (Figure 3.11 has a similar chemical composition. Background ground water quality data show some variability but fall into the same general chemical field. Variability in water chemistry can be explained by 1) distance of the well from the river (TDSs decrease away from the river) and 2) depth of the well (TDSs appear to decrease with depth due to the diminishing effect of evaporation with depth).

The San Juan River influences ground water quality adjacent to the river channel. The solute load of the river varies, depending upon which formation the river flows through, the amount of water each tributary contributes to flow, the evaporation rate, and the volume of flow in the river. Because of these effects, ground water chemistry is not homogeneous in the floodplain adjacent to the river. Sulfate/ chloride ratios in background wells in the alluvial aquifer range from 16 to 37 , illustrating the variability in solute concentrations in this system. A statistical summary of water quality data for the four alluvial wells used to determine background is shown in Table 3.2. 


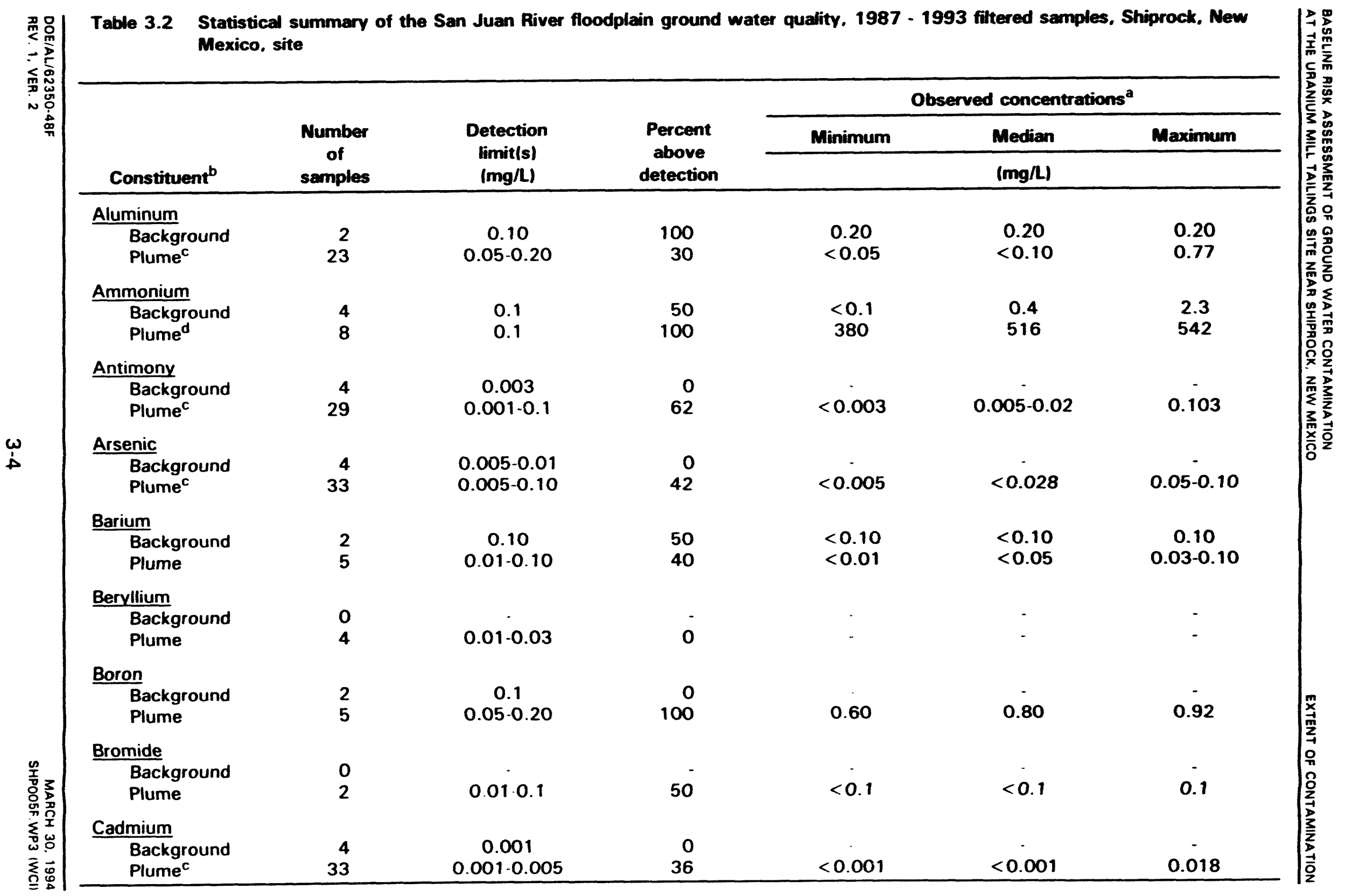




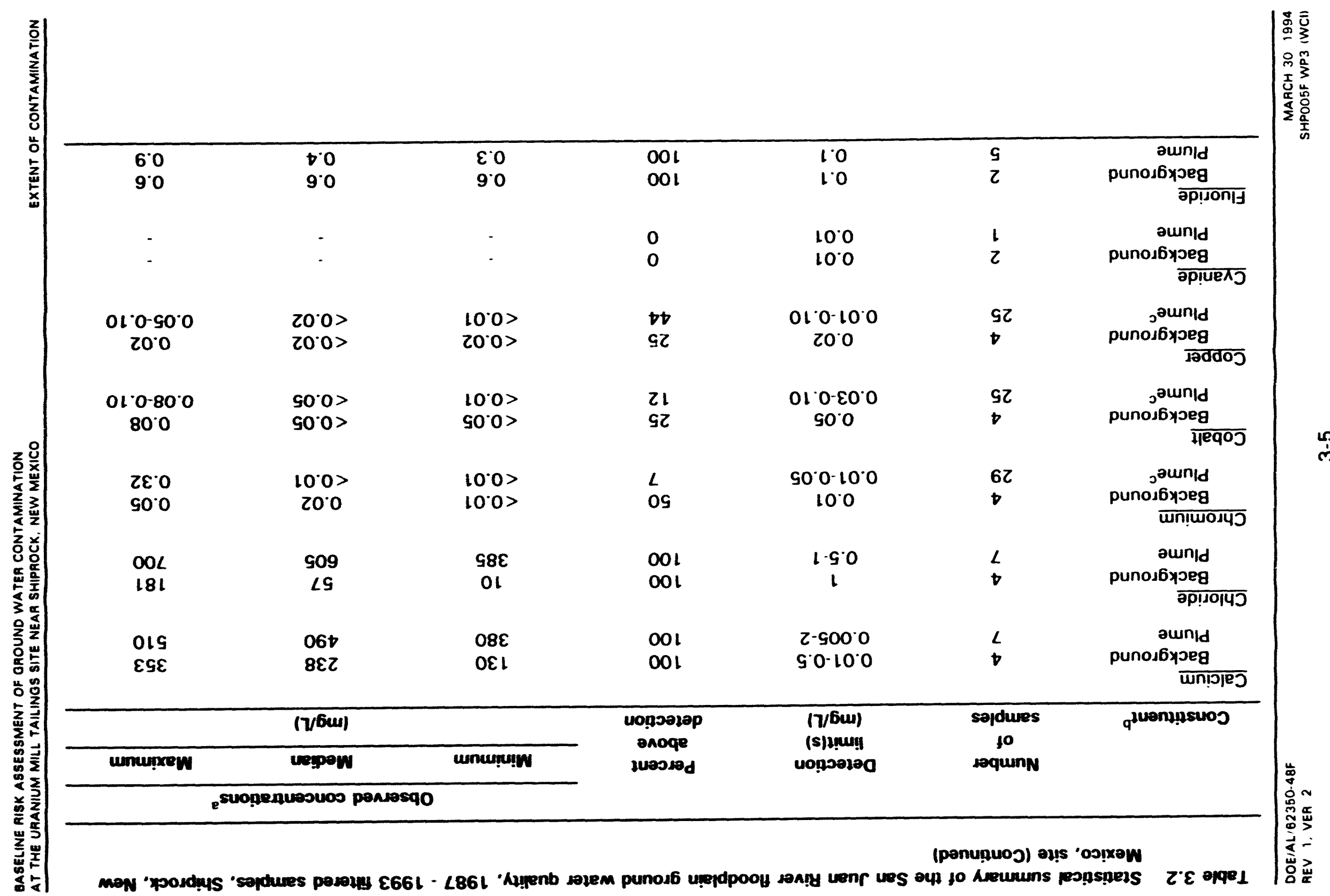




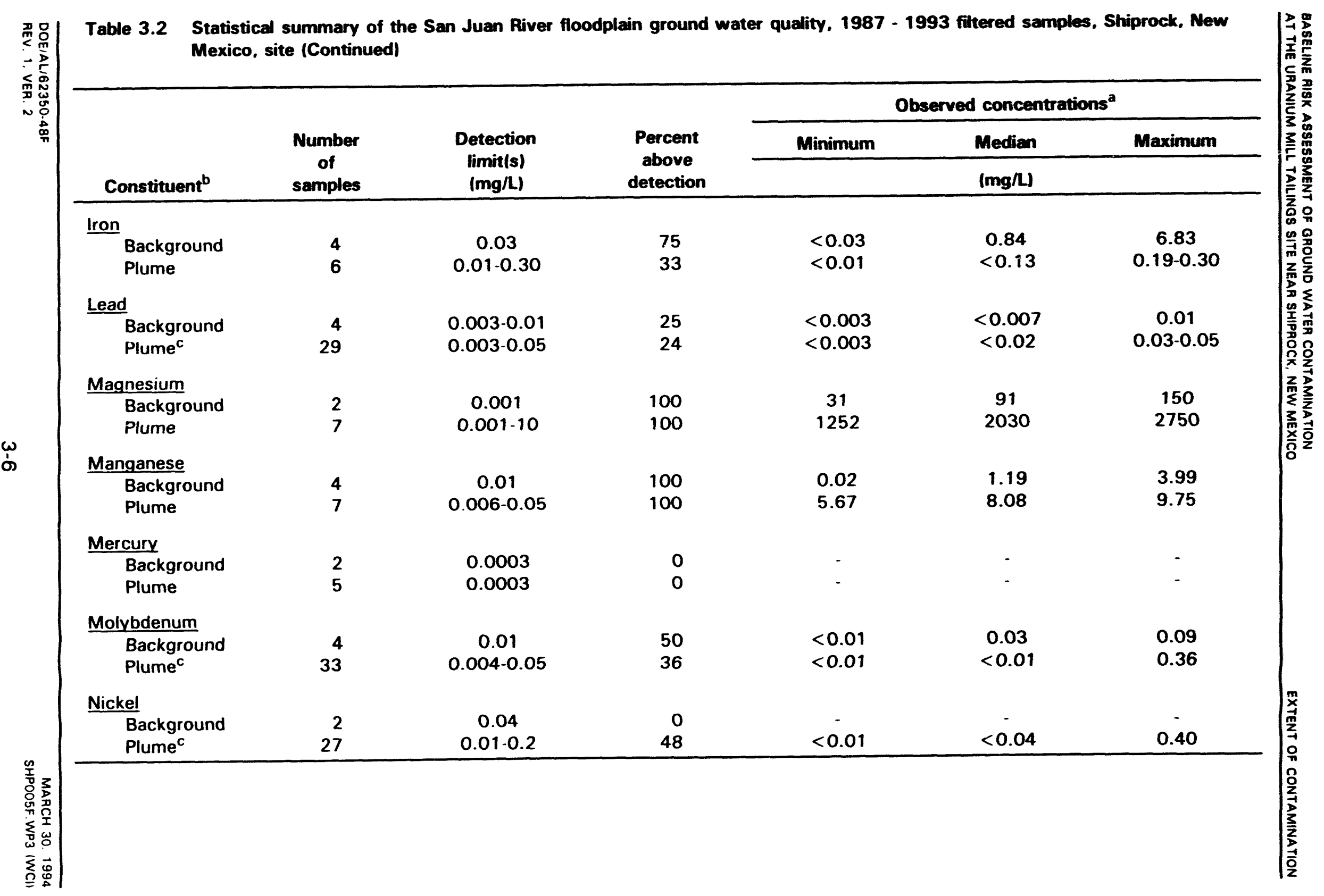




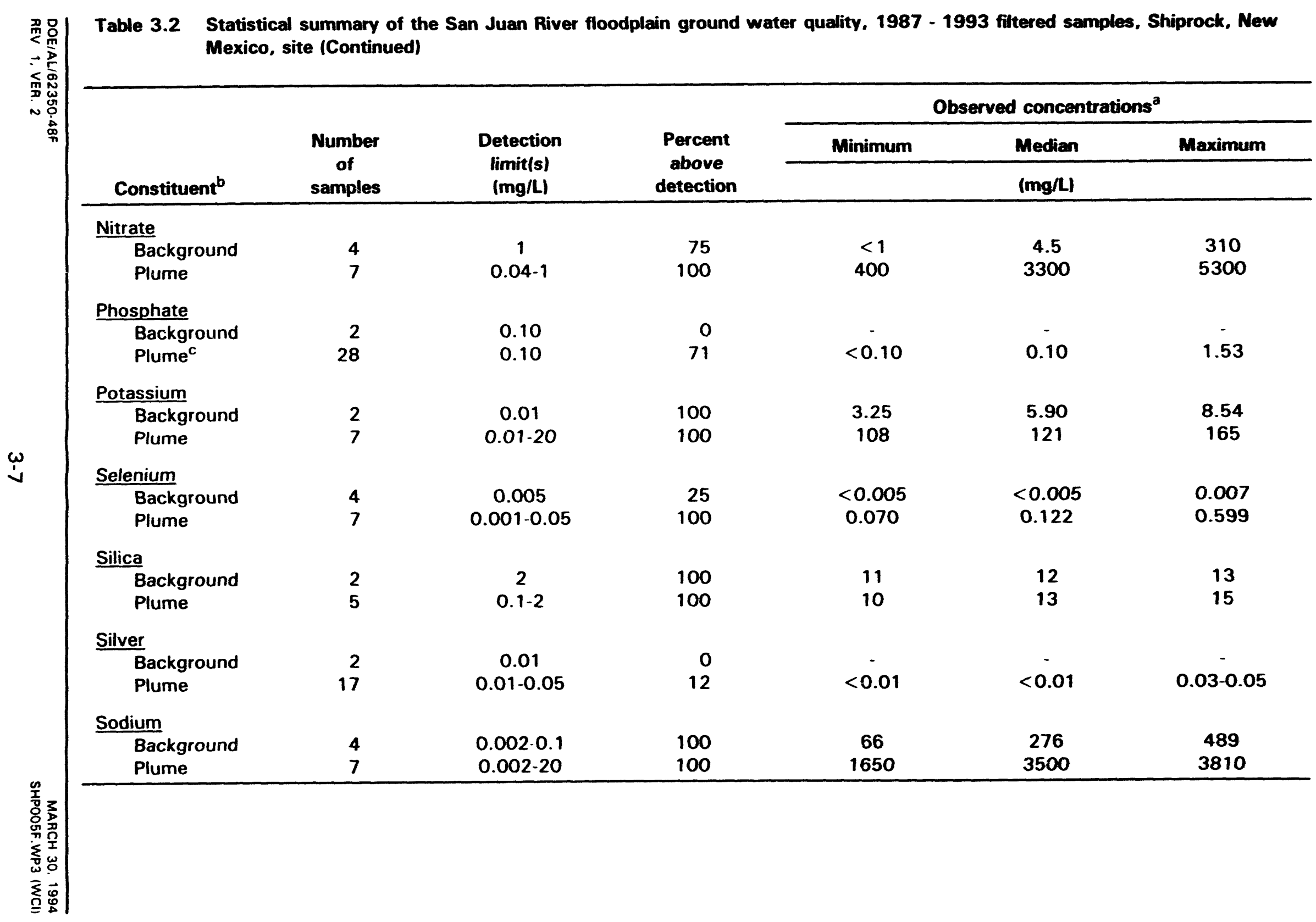




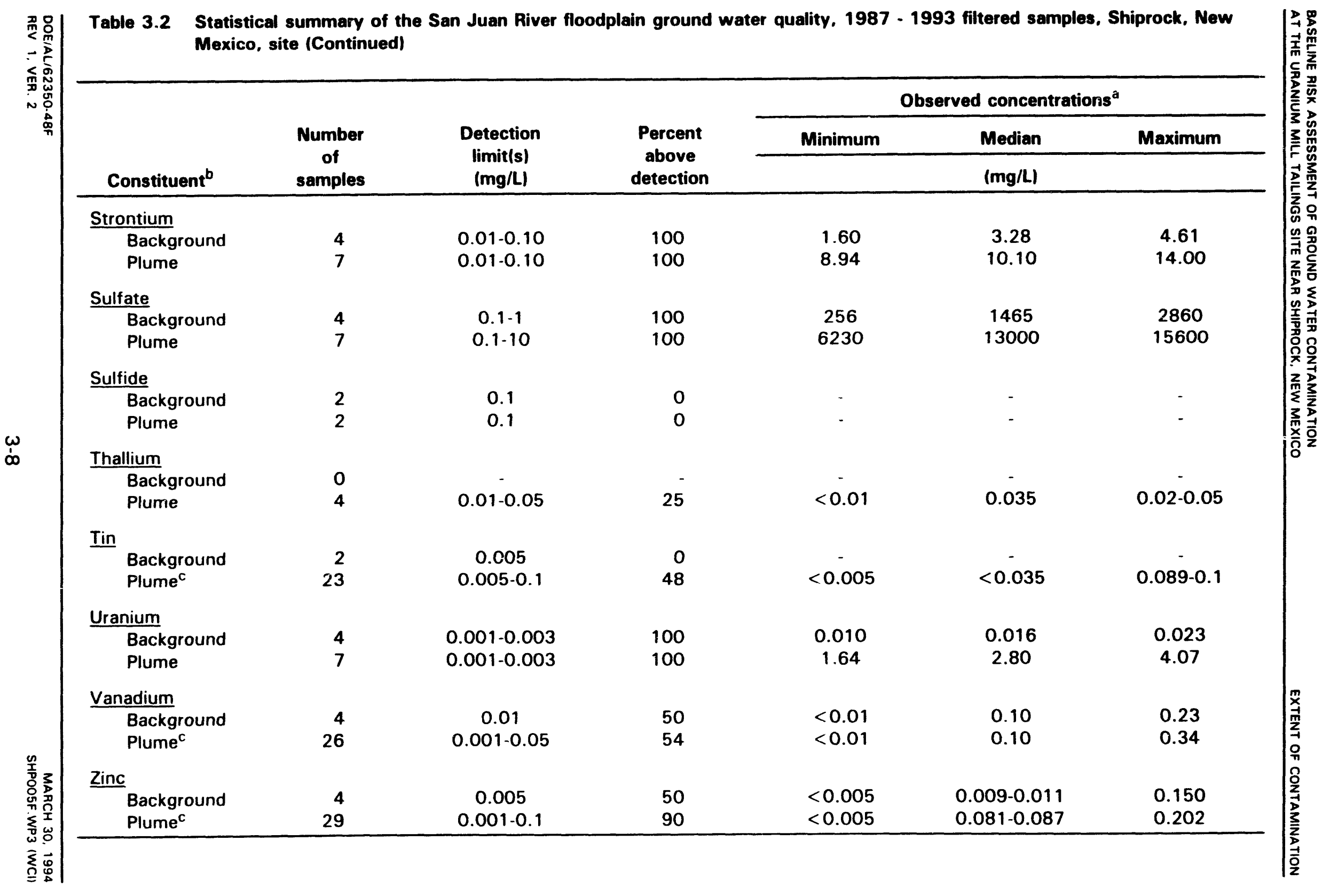




\begin{tabular}{|c|c|c|c|c|c|}
\hline \multirow{16}{*}{ 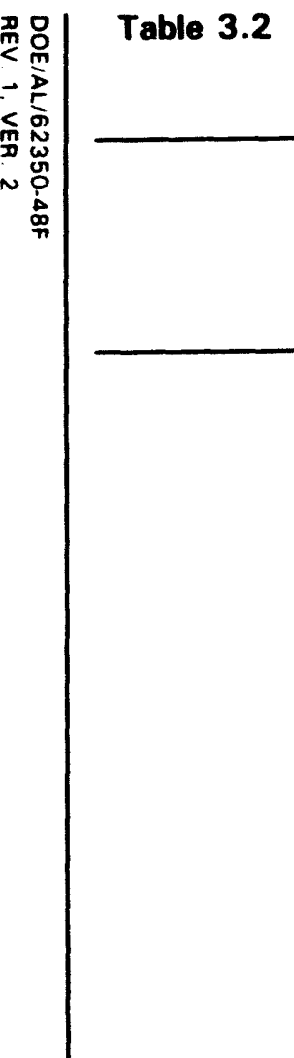 } & \multicolumn{5}{|c|}{$\begin{array}{l}\text { Statistical summary of the San Juan River floodplain ground water quality, } 1987 \text { - } 1993 \text { filtered samples, Shiprock, New } \\
\text { Mexico, site (Concluded) }\end{array}$} \\
\hline & \multirow[b]{3}{*}{ Constituent $^{b}$} & \multirow{3}{*}{$\begin{array}{c}\text { Number } \\
\text { of } \\
\text { samples }\end{array}$} & \multicolumn{2}{|c|}{ Observed concentrations $^{\mathrm{a}}$} & \\
\hline & & & Minimum & Median & Maximum \\
\hline & & & & (pCi/L) & \\
\hline & \multicolumn{5}{|l|}{ Radionuclides } \\
\hline & \multicolumn{5}{|l|}{ Lead-210 } \\
\hline & Background & 2 & 0.00 & 0.05 & 0.10 \\
\hline & \multirow{2}{*}{\multicolumn{5}{|c|}{ Polonium-210 }} \\
\hline & Background & & & & \\
\hline & Plume ${ }^{c}$ & 13 & 0.0 & 0.6 & 3.3 \\
\hline & \multicolumn{5}{|l|}{ Radium-226 } \\
\hline & Background & 2 & 0.0 & 0.1 & 0.2 \\
\hline & Plume $^{c}$ & 32 & 0.0 & 0.2 & 3.0 \\
\hline & \multicolumn{5}{|l|}{ Thorium-230 } \\
\hline & Background & 2 & 0.20 & 0.30 & 0.40 \\
\hline & Plume ${ }^{c}$ & 14 & 0.00 & 0.35 & 1.60 \\
\hline
\end{tabular}

${ }^{a}$ Due to nondetectable measurements, these statistics may not be available. If a range is reported, the statistic is known to lie somewhere within that range.

bPlume data are from well 615 except as noted. Background data are from wells 634, 635, 732, and 733.

cBecause of low detectability, data from the following plume wells were combined: $608,609,610,611,613,614$, and 615 .

${ }^{d}$ Well 608 was used to determine ammonium concentration.

pCi/L - picocuries per liter. 


\subsection{MAGNITUDE OF SITE-RELATED CONTAMINATION}

\subsubsection{Terrace alluvium}

Ground water within the terrace alluvium is present in alluvial gravels and the upper weathered zone of the Mancos Shale Formation. It is not known whether ground water was present in the alluvial terrace before milling activities began. During mill operations, tailings leachate and tailings were discharged to tailings embankments adjacent to the mill site. Raffinate was discharged to evaporation ponds east and south of the tailings embankments.

Fluids from both raffinate and tailings containment structures infiltrated the subsurface, contaminating ground water in the terrace alluvium. As a result of milling activities, a ground water mound probably developed beneath the site. Ground water then flowed away from the site in all directions, imposing a temporary gradient on the terrace alluvium system. The mound has since subsided, but residual contamination remains.

Water quality data from existing wells on the terrace demonstrate the impact on water quality from milling activities (Table 3.3). Ground water from monitor wells 600 and 602, analyzed between 1988 and 1993, show high concentrations of uranium, nitrate, and sulfate. Ground water samples from monitor wells 725,726 , 727,728 , and 731 , constructed in the spring of 1993, were also high in nitrate, uranium, and sulfate. The latest drilling program better defined the extent of the plume to the east, south, and west of the disposal cell. However, the location of the edge of the plume is still unknown.

Ground water flowing from the terrace alluvium to the alluvial floodplain probably contaminates ground water in the alluvial floodplain system. Water quality data from seeps originating in the terrace alluvium show elevated nitrate, uranium, and sulfate. Groundwater has not been screened for organic contaminants. However, a solvent extraction process to recover uranium from the pregnant solution was used at the site. Additional sampling and analyses would be needed to completely rule out the possibility of organic contamination.

\subsubsection{Alluvial floodplain}

The alluvial floodplain is characterized by elevated TDSs and other constituents associated with uranium milling (e.g., sulfate, nitrate, and uranium). The sulfate, nitrate, and uranium plumes are delineated in Figures 3.2, 3.3, and 3.4. Ground water sampled from the floodplain wells has TDS values ranging from 700 to $64,200 \mathrm{mg} / \mathrm{L}$ and a $\mathrm{pH}$ ranging from 6.5 to 8.0 . The wide variability may be caused by the presence of several plumes that contribute to the overall plume on the floodplain. These plumes may have formed from leachate and raffinate spills from the terrace onto the floodplain or from ponds (on the floodplain) used during mill operations. 


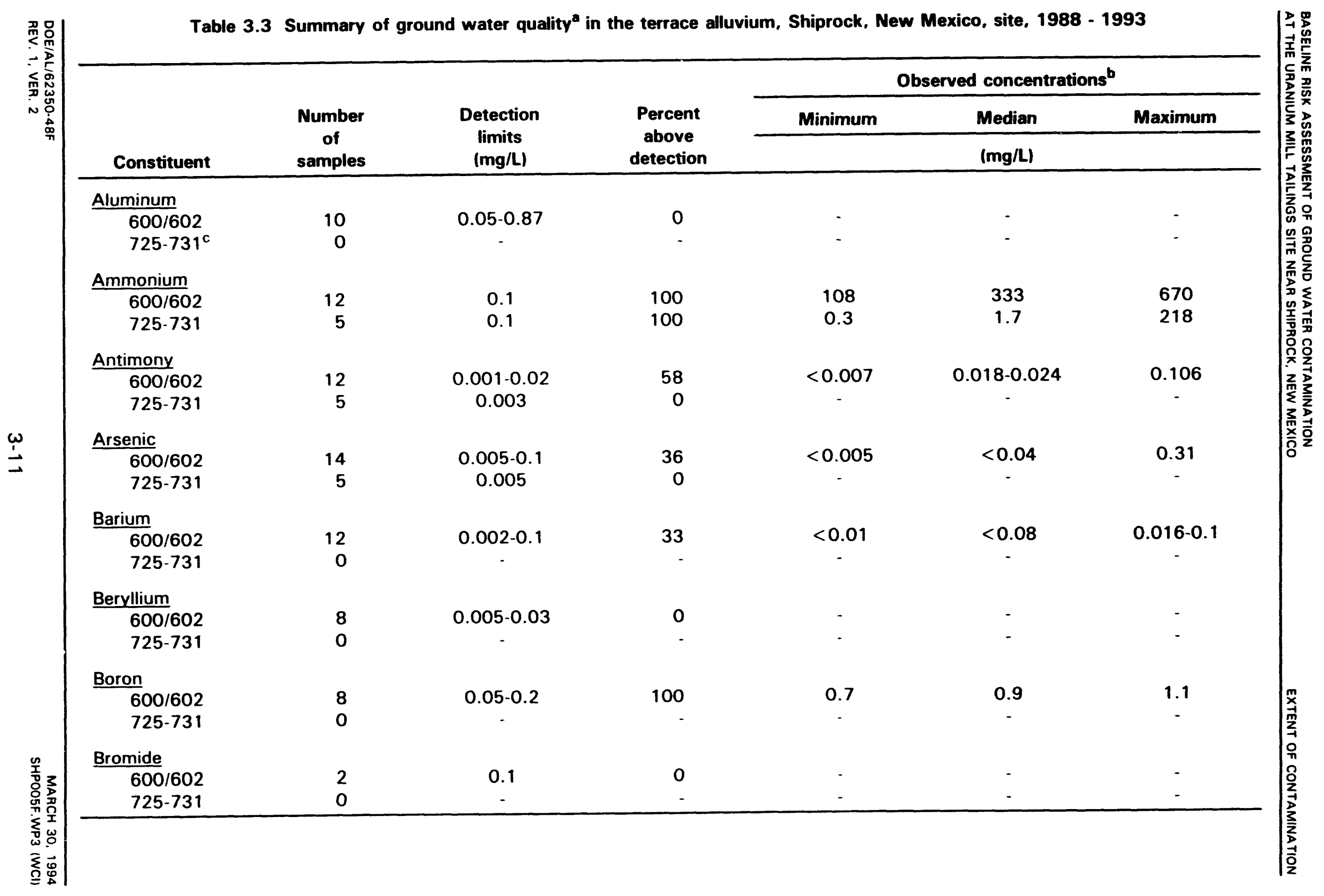




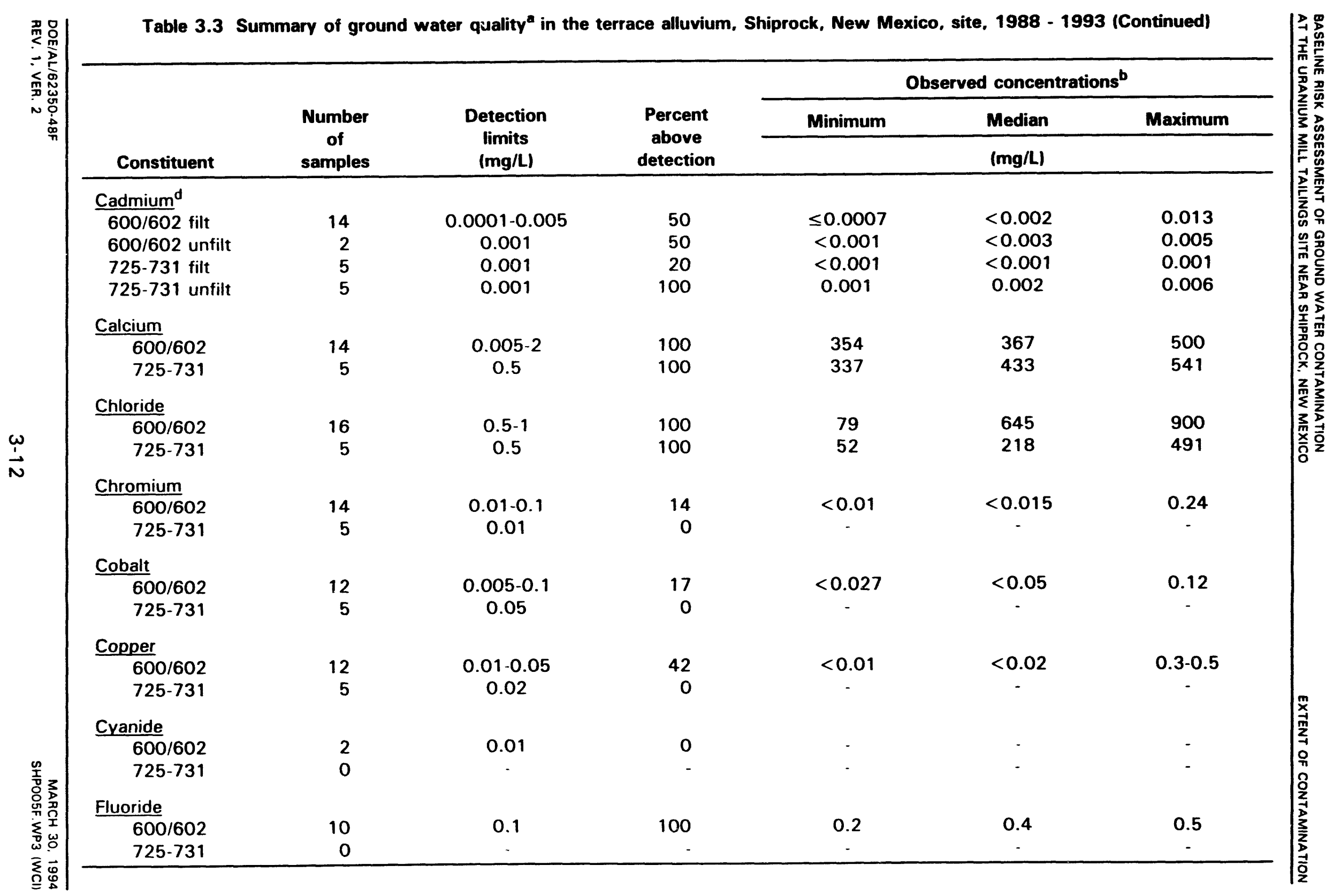




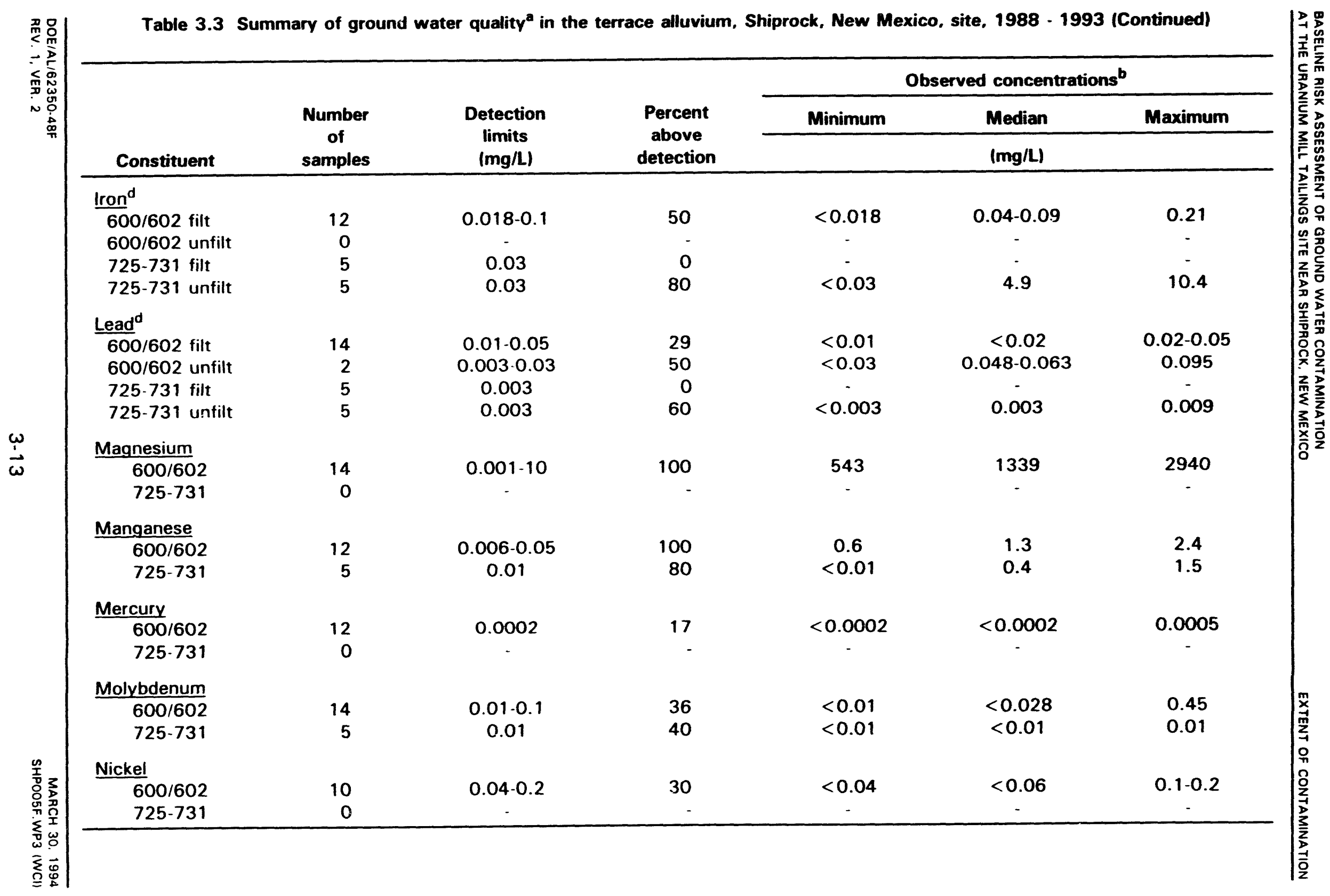




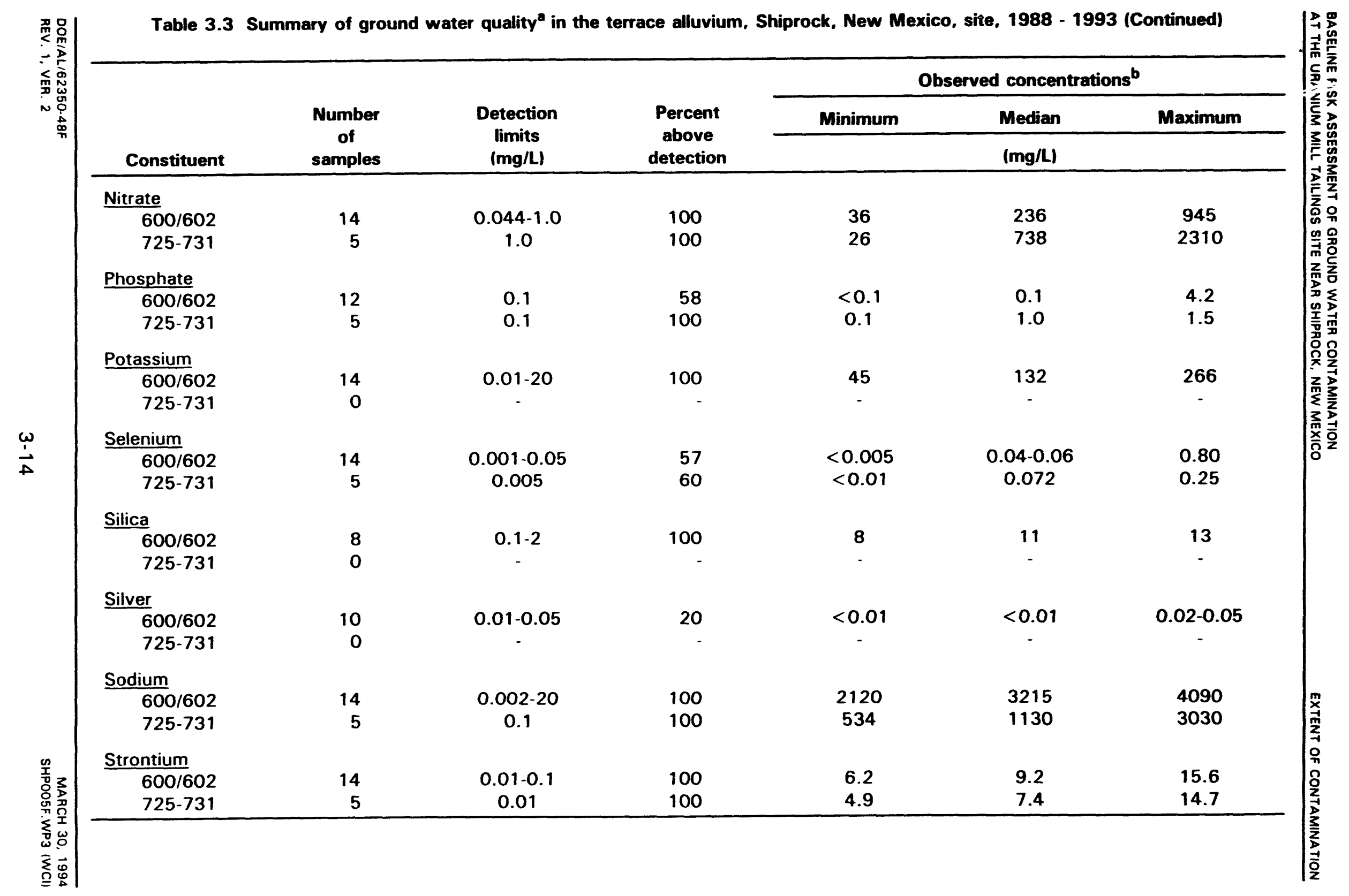









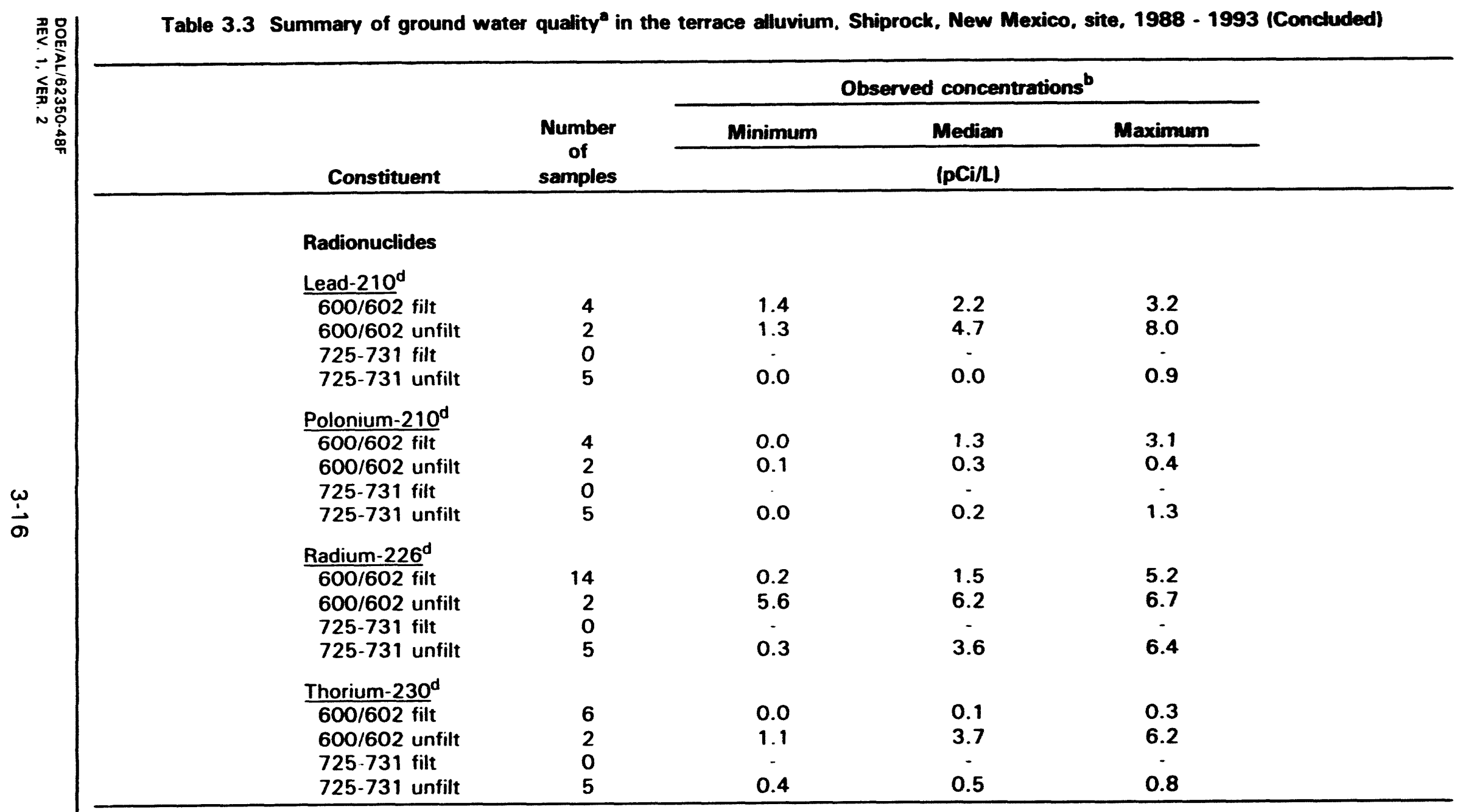

aData are from filtered samples unless otherwise noted.

bDue to nondetected measurements, these statistics may not be observable. If a range is given, the statistic is known to lie somewhere within the range.

c725-731 refers to wells $725,726,727,728$, and 731. These wells were sampled only once, in 1993.

${ }^{d}$ Concentrations from both filtered and unfiltered samples are presented for those constituents where filtering may be expected to remove a significant amount of the constituent from the water. However, when concentrations are low, natural variation and measurement error may be greater than the effects of filtering. 


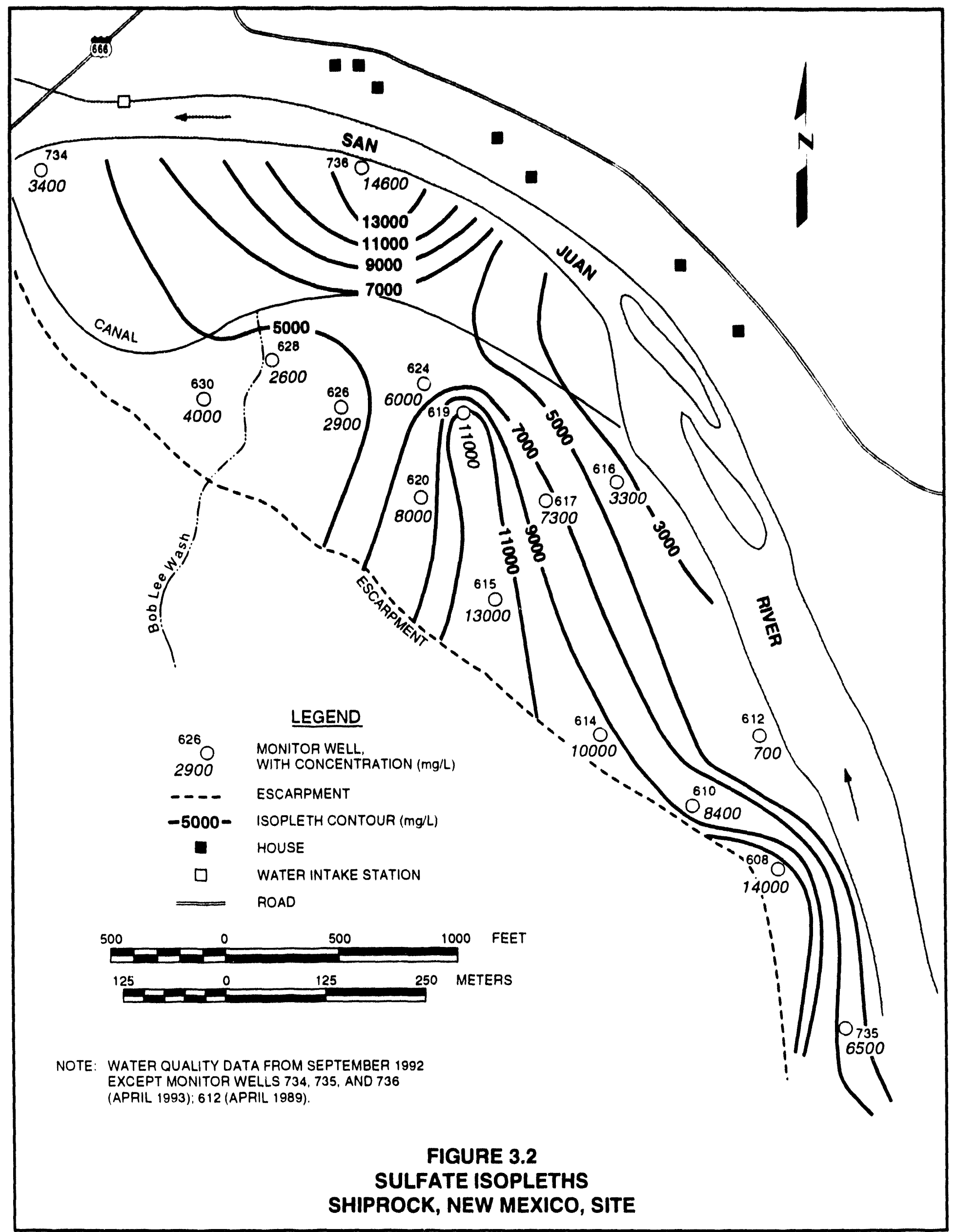




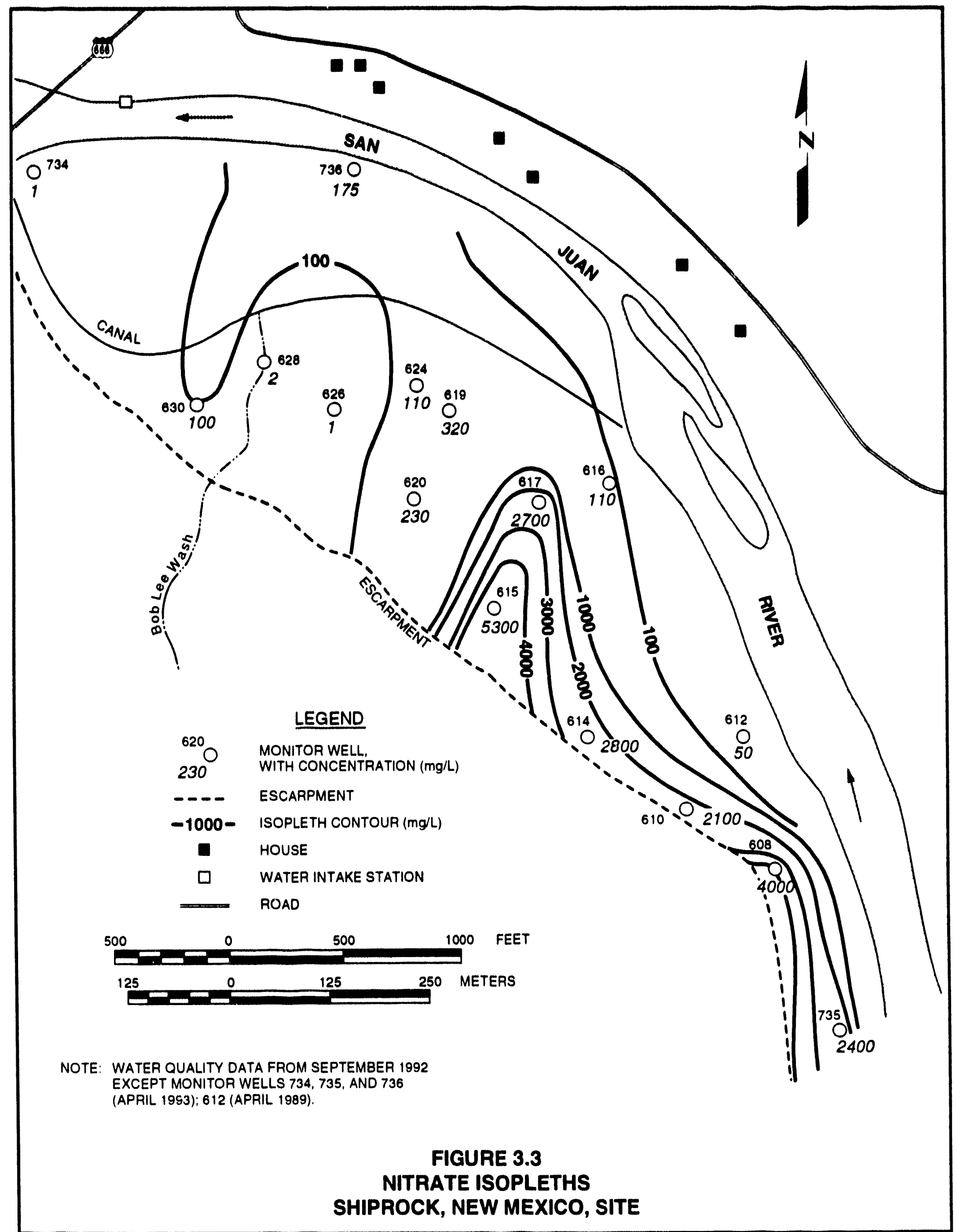




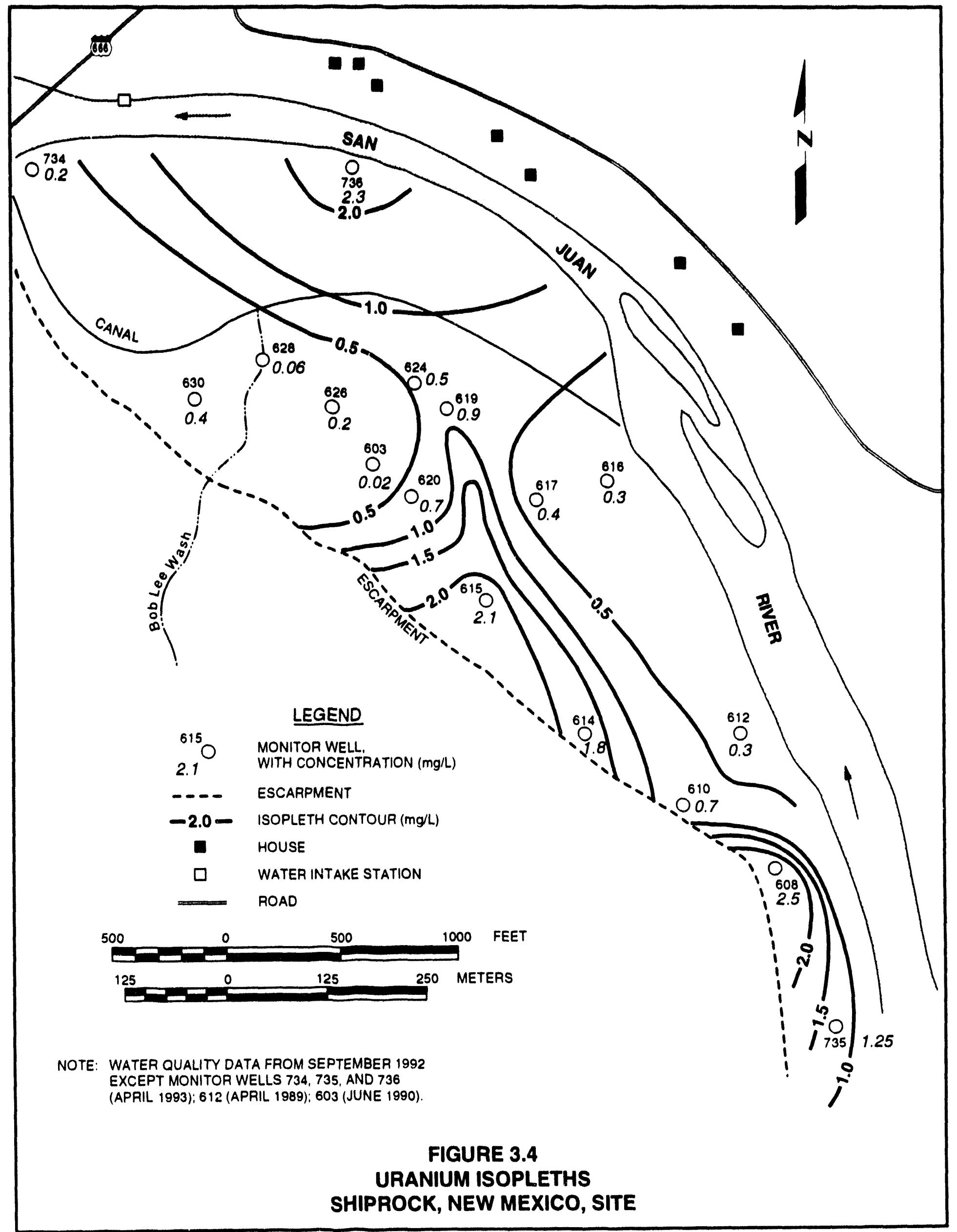


Monitor wells 608 through 611 and wells 613,614 and 615 (Figure 2.7) are in the plume along the base of the escarpment. Filtered water quality data collected between 1987 and 1993 indicate that monitor wells 608 and 615 have the highest concentrations of milling-related contaminants. Monitor well 612 appears to be affected by the flow in the San Juan River, especially during periods of high water flow. The remaining wells in the floodplain are located downgradient from the centroid of the plume and ground water accessed by these wells is not as contaminated. Generally, ground water contamination in the floodplain shows a complex, nonhomogeneous distribution.

To characterize water quality in the floodplain and to determine constituents that are elevated above background, water quality data from the well showing the worst contamination between 1987 and 1993 were used. In most cases, data from well 615 were used because concentrations were slightly but consistently higher than in well 608. However, in the case of ammonium, data from well 608 were used because the highest concentrations of ammonium appear in a limited area around well 608. Many constituents were detected only sporadically at levels near or below the laboratory detection limits in the floodplain. For constituents with very low detectability, it was necessary to pool data from wells 608 through 611 and 613 through 615 to assess possible contamination. Plume water quality data are summarized in Table 3.2.

Nineteen constituents were statistically elevated above background in the alluvial floodplain ground water. These constituents are ammonium, antimony, arsenic, boron, cadmium, calcium, chloride, magnesium, manganese, nickel, nitrate, phosphate, potassium, selenium, sodium, strontium, sulfate, uranium, and zinc.

Time series plots of chemical constituents show slight trends, either increasing or decreasing, of solute concentrations in ground water. In the most highly impacted area of the floodplain (the eastern portion), species such as nitrate and chloride appear to be increasing, sulfate and TDS are constant, and uranium shows a slight decrease. Observable concentrations of selenium and arsenic in ground water are sporadic, most likely caused by analytical inconsistencies. Erratic behavior in the data probably indicates that numerous plumes are traveling through the alluvial system, affecting wells on an individual basis. This may be consistent with ponds and/or episodic discharges on different portions of the floodplain, which would have produced several plumes, and/or preferential flow paths through more permeable zones.

\subsection{CONTAMINANTS OF POTENTIAL CONCERN}

The data presented in Sections 3.1 and 3.2 were used to compile a list of contaminants that are of potential concern for the assessment of human health or environmental risks at the Shiprock site. Because background water quality data are not available for the terrace alluvium, constituents that are highly elevated and clearly associated with the site are evaluated as contaminants of concern. This includes uranium, sulfate, and nitrate. 
For the floodplain alluvium, a constituent was placed on the list of contaminants of potential concern if the constituent was detected at concentrations statistically above background monitor wells and if the site is a likely source of the contamination. Constituents exceeding background are shown in Table 3.4.

The constituents identified in column 1 of Table 3.4 were screened for their potential to affect human health, using the criteria discussed below, in order to develop a final list of contaminants of potential concern for human health. Because ecological impacts differ from effects on human health, the complete list of contaminants will be considered for ecological risk assessment in Section 7.0.

Several constituents that were above background were further screened because they are essential nutrients and the levels at which they are detected are within nutritional ranges. These constituents are calcium, chloride, phosphate, potassium, and zinc.

Boron and nickel were eliminated as contaminants of potential concern based on very low toxicity and a relatively high normal dietary intake. Although ammonium is not considered a dietary component, it is produced in the human body at levels that exceed $4000 \mathrm{mg} /$ day (Summerskill and Wolpert, 1970). This level is roughly the order of magnitude that results from ingesting the most ammoniumcontaminated water at the site $(542 \mathrm{mg} / \mathrm{L})$. Although these levels are substantially higher than background, they are not expected to be associated with adverse health effects. However, the detected concentrations are likely to affect the taste and odor of the water. Antimony, arsenic, cadmium, magnesium, manganese, nitrate, selenium, sodium, strontium, sulfate, and uranium remain as contaminants of potential concern (Table 3.4).

\subsection{CONTAMINANT FATE AND TRANSPORT}

Contaminant mobility, uptake, and toxicity depend on the species of elements that exist in an aqueous environment. The type and concentrations of species and complexes in natural waters depend on the concentration, availability of various anions and cations, and $\mathrm{pH}$ and Eh conditions. Species of the contaminants of concern have been calculated using the geochemical code MINTEQA2 (Allison et al., 19911. Predominant species and their molar percentages are summarized in Table 3.5 .

The concentration of contaminants in the plume at Shiprock will be influenced by dilution (dispersive effects) and chemical reactions such as oxidation/reduction, sorption onto the aquifer matrix, coprecipitation with other mineral phases, microbial reactions, transport due to advective flow of ground water, and also radioactive decay. Antimony will probably precipitate (from oversaturation). Arsenic, selenium, and uranium will be attenuated due to sorption onto mineral surfaces and dilution. Magnesium will experience dilution and cation exchange with other cations in clay minerals. Sodium is somewhat conservative for a cation but exchanges with other cations in clays and undergoes dilution. Even though the kinetics of manganese precipitation are slow, precipitation and dilution will likely 
Table 3.4 Contaminants of potential concern for the San Juan River floodplain, Shiprock, Now Mexico, site

\begin{tabular}{lccc}
\hline $\begin{array}{c}\text { Contaminant levels } \\
\text { exceed background }\end{array}$ & $\begin{array}{c}\text { Contaminant levels } \\
\text { in nutritional range }\end{array}$ & $\begin{array}{c}\text { Contaminants of low } \\
\text { toxicity and/or high } \\
\text { dietary range }\end{array}$ & $\begin{array}{c}\text { Contaminants of } \\
\text { potential concern }\end{array}$ \\
\hline Ammonium & Calcium & Ammonium & Antimony \\
Antimony & Chloride & Boron & Arsenic \\
Arsenic & Phosphate & Nickel & Cadmium \\
Boron & Potassium & & Magnesium \\
Cadmium & Zinc & & Manganese \\
Calcium & & & Nitrate \\
Chloride & & Selenium \\
Magnesium & & Sodium \\
Manganese & & Strontium \\
Nickel & & Sulfate \\
Nitrate & & Uranium \\
Phosphate & & \\
Potassium & & \\
Selenium & & \\
Sodium & & \\
Strontium & & \\
Sulfate & & \\
Uranium & & \\
Zinc & & \\
\hline
\end{tabular}


Table 3.5 Chemical speciation

\begin{tabular}{|c|c|c|c|}
\hline $\begin{array}{c}\text { Contaminant of } \\
\text { potential concern }\end{array}$ & $\begin{array}{c}\text { Common } \\
\text { name }\end{array}$ & $\begin{array}{l}\text { Identity of species } \\
\text { in ground water }\end{array}$ & $\begin{array}{c}\text { Approximate } \\
\text { molar } \\
\text { percentage }\end{array}$ \\
\hline Antimony & $\begin{array}{l}\text { Antimony hydroxide } \\
\text { Antimony dioxide }\end{array}$ & $\begin{array}{l}\mathrm{Sb}(\mathrm{OH})_{3} \\
\mathrm{HSbO}_{2}\end{array}$ & $\begin{array}{l}50 \\
50\end{array}$ \\
\hline Arsenic & $\begin{array}{l}\text { Arsenate } \\
\text { Arsenate }\end{array}$ & $\begin{array}{l}\mathrm{H}_{2} \mathrm{AsO}_{4} \\
\mathrm{HAsO}_{4}{ }^{2}-\end{array}$ & $\begin{array}{l}25 \\
75\end{array}$ \\
\hline Cadmium & $\begin{array}{l}\text { Cadmium disulfate } \\
\text { Cadmium sulfate } \\
\text { Cadmium } \\
\text { Cadmium chloride } \\
\text { Cadmium nitrate } \\
\text { Cadmium carbonate }\end{array}$ & $\begin{array}{l}\mathrm{Cd}\left(\mathrm{SO}_{4}\right)_{2}{ }^{2} \\
\mathrm{Cd}\left(\mathrm{SO}_{4}\right)^{\mathrm{AO}} \\
\mathrm{Cd}^{2+} \\
\mathrm{CdCl}^{+} \\
\mathrm{CdNO}_{3}{ }^{+} \\
\mathrm{CdCO}_{3} \mathrm{AO}\end{array}$ & $\begin{array}{r}37 \\
30 \\
21 \\
7 \\
3 \\
2\end{array}$ \\
\hline Magnesium & $\begin{array}{l}\text { Magnesium } \\
\text { Magnesium sulfate } \\
\text { Magnesium bicarbonate }\end{array}$ & $\begin{array}{l}\mathrm{Mg}^{2+} \\
\mathrm{MgSO}_{4} \mathrm{AO} \\
\mathrm{MgHCO}_{3}^{+}\end{array}$ & $\begin{array}{r}53 \\
45 \\
2\end{array}$ \\
\hline Manganese & $\begin{array}{l}\text { Manganese } \\
\text { Manganese sulfate } \\
\text { Manganese bicarbonate }\end{array}$ & $\begin{array}{l}\mathrm{Mn}^{2+} \\
\mathrm{MnSO}_{4} \mathrm{AO} \\
\mathrm{MnHCO}_{3}^{+}\end{array}$ & $\begin{array}{r}54 \\
44 \\
2\end{array}$ \\
\hline Nitrogen & Nitrate & $\mathrm{NO}_{3}^{-}$ & 100 \\
\hline Selenium & $\begin{array}{l}\text { Selenite } \\
\text { Selenite }\end{array}$ & $\begin{array}{l}\mathrm{HSeO}_{3} \\
\mathrm{SeO}_{3}{ }^{2}\end{array}$ & $\begin{array}{r}95 \\
5\end{array}$ \\
\hline Sodium & $\begin{array}{l}\text { Sodium } \\
\text { Sodium sulfate }\end{array}$ & $\begin{array}{l}\mathrm{Na}^{+} \\
\mathrm{NaSO}_{4}\end{array}$ & $\begin{array}{l}90 \\
10\end{array}$ \\
\hline Strontium & Strontium & $\mathrm{Sr}^{2+}$ & 100 \\
\hline Sulfur & $\begin{array}{l}\text { Sulfate } \\
\text { Magnesium sulfate } \\
\text { Sodium sulfate } \\
\text { Calcium sulfate }\end{array}$ & $\begin{array}{l}\mathrm{SO}_{4}{ }^{2-} \\
\mathrm{MgSO}_{4} \mathrm{AO} \\
\mathrm{NaSO}_{4} \\
\mathrm{CaSO}_{4} \mathrm{AO}\end{array}$ & $\begin{array}{r}56 \\
31 \\
10 \\
3\end{array}$ \\
\hline Uranium & $\begin{array}{l}\text { Uranyl tricarbonate } \\
\text { Uranyl dicarbonate }\end{array}$ & $\begin{array}{l}\mathrm{UO}_{2}\left(\mathrm{CO}_{3}\right)_{3}^{4-} \\
\mathrm{UO}_{2}\left(\mathrm{CO}_{3}\right)_{2}^{2-}\end{array}$ & $\begin{array}{l}88 \\
12\end{array}$ \\
\hline
\end{tabular}


reduce concentration in ground water. According to geochemical modeling, cadmium is undersaturated, leaving dilution and sorption (ion exchange) as the main mechanisms of attenuation. Strontium concentrations will decrease through time due to coprecipitation with carbonate and sulfate phases. Concentrations of nitrate may be reduced through microbially mediated denitrification reactions in which nitrate is reduced to ammonium and then nitrogen gas which is vented to the atmosphere.

The precipitation of select mineral phases will remove contaminants from ground water. The most contaminated ground water in the floodplain is oversaturated with respect to gypsum and antimony trihydroxide. These minerals may be expected to precipitate in the pores of the aquifer matrix if the kinetics of reaction are favorable. Gypsum precipitates aln iust instantaneously but little is known about the behavior of antimony phases.

\subsection{SURFACE WATER MONITORING}

The impact of milling activities on water quality of the San Juan River cannot be determined with certainty. Varıable flow of the San Juan River and erratic contributions from its tributaries make meaningful sampling difficult because the water chemistry varies with the rate of flow, hydrochemical origın, and season.

Sampling locations for San Juan River surface water quality are shown in Figure 2.8. Analyses of one round of unfiltered water samples from seven San Juan River sampling locations 1546,552 , and 554 upstream and 548, 549, 550, and 551 downstreaml, collected in February 1993, are summarized in Table 3.6. These sampling locations will be monitored in the future to generate a more statistically meaningful data base. As can be seen from Table 3.6, downstream concentrations of arsenic, nitrate, sodium, and sulfate are statistically above background determined at the upstream locations. The remaining sampled constituents are at or below background values.

Recharge of contaminated ground water from the alluvial floodplain may contribute constituents to the San Juan River. However, recharge is thought to be predominantly responsible for the flux of solute to the San Juan River in the downstream half of the floodplain.

To estimate the impact of contaminated ground water on water quality in the San Juan River, the contribution of contaminant flux from the alluvial aquifer to the San Juan River was calculated. The following instantaneous mixing equation was used to calculate the potential impact:

$$
C_{f}=\frac{Q_{g w} C_{g w}+Q_{r} C_{r}}{Q_{g w}+Q_{r}}
$$


Table 3.6 Statistical summary of the San Juan River water quality at the Shiprock UMTRA site, New Mexico," February 25, 1993

\begin{tabular}{|c|c|c|c|c|c|}
\hline \multirow[b]{2}{*}{ Constituent } & \multirow[b]{2}{*}{$\begin{array}{c}\text { Number of } \\
\text { samples }\end{array}$} & \multirow[b]{2}{*}{$\begin{array}{c}\text { Detection } \\
\text { limit }\end{array}$} & \multicolumn{3}{|c|}{$\begin{array}{c}\text { Observed concentrations } \\
\text { (mg/L) }\end{array}$} \\
\hline & & & Minimum & Median & Maximum \\
\hline $\begin{array}{l}\text { Arsenic }^{b} \\
\text { Upstream }^{c} \\
\text { Downstream }^{d}\end{array}$ & $\begin{array}{l}3 \\
4\end{array}$ & $\begin{array}{l}0.005 \\
0.005\end{array}$ & $\begin{array}{l}0.007 \\
0.008\end{array}$ & $\begin{array}{l}0.007 \\
0.010\end{array}$ & $\begin{array}{l}0.008 \\
0.012\end{array}$ \\
\hline $\begin{array}{l}\text { Cadmium } \\
\text { Upstream } \\
\text { Downstream }\end{array}$ & $\begin{array}{l}3 \\
4\end{array}$ & $\begin{array}{l}0.001 \\
0.001\end{array}$ & - & - & - \\
\hline $\begin{array}{l}\text { Calcium } \\
\text { Upstream } \\
\text { Downstream }\end{array}$ & $\begin{array}{l}3 \\
4\end{array}$ & $\begin{array}{l}0.5 \\
0.5\end{array}$ & $\begin{array}{l}73 \\
69\end{array}$ & $\begin{array}{l}73 \\
90\end{array}$ & $\begin{array}{l}77 \\
95\end{array}$ \\
\hline $\begin{array}{l}\text { Chromium } \\
\text { Upstream } \\
\text { Downstream }\end{array}$ & $\begin{array}{l}3 \\
4\end{array}$ & $\begin{array}{l}0.01 \\
0.01\end{array}$ & $\begin{array}{l}0.03 \\
0.03\end{array}$ & $\begin{array}{l}0.03 \\
0.05\end{array}$ & $\begin{array}{l}0.03 \\
0.07\end{array}$ \\
\hline $\begin{array}{l}\text { Iron } \\
\text { Upstream } \\
\text { Downstream }\end{array}$ & $\begin{array}{l}3 \\
4\end{array}$ & $\begin{array}{l}0.03 \\
0.03\end{array}$ & $\begin{array}{l}42 \\
40\end{array}$ & $\begin{array}{l}44 \\
54\end{array}$ & $\begin{array}{l}47 \\
69\end{array}$ \\
\hline $\begin{array}{l}\text { Lead } \\
\text { Upstream } \\
\text { Downstream }\end{array}$ & $\begin{array}{l}3 \\
4\end{array}$ & $\begin{array}{l}0.003 \\
0.003\end{array}$ & $\begin{array}{l}0.024 \\
0.024\end{array}$ & $\begin{array}{l}0.025 \\
0.030\end{array}$ & $\begin{array}{l}0.026 \\
0.032\end{array}$ \\
\hline $\begin{array}{l}\text { Manganese } \\
\text { Upstream } \\
\text { Downstream }\end{array}$ & $\begin{array}{l}3 \\
4\end{array}$ & $\begin{array}{l}0.01 \\
0.01\end{array}$ & $\begin{array}{l}1.03 \\
0.88\end{array}$ & $\begin{array}{l}1.12 \\
1.10\end{array}$ & $\begin{array}{l}1.23 \\
1.17\end{array}$ \\
\hline $\begin{array}{l}\text { Molybdenum } \\
\text { Upstream } \\
\text { Downstream }\end{array}$ & $\begin{array}{l}3 \\
4\end{array}$ & $\begin{array}{l}0.01 \\
0.01\end{array}$ & - & - & $\dot{-}$ \\
\hline $\begin{array}{l}\text { Nitrate }^{\mathrm{b}} \\
\text { Upstream } \\
\text { Downstream }\end{array}$ & $\begin{array}{l}3 \\
4\end{array}$ & $\begin{array}{l}1.0 \\
1.0\end{array}$ & $\begin{array}{r}<1.0 \\
1.1\end{array}$ & $\begin{array}{r}<1.0 \\
1.5\end{array}$ & $\begin{array}{r}<1.0 \\
1.7\end{array}$ \\
\hline $\begin{array}{l}\text { Selenium }{ }^{\ominus} \\
\text { Upstream } \\
\text { Downstream }\end{array}$ & $\begin{array}{l}3 \\
4\end{array}$ & $\begin{array}{l}0.05 \\
0.05\end{array}$ & - & - & $\cdot$ \\
\hline $\begin{array}{l}\text { Sodium } \\
\text { Upstream } \\
\text { Downstream }\end{array}$ & $\begin{array}{l}3 \\
4\end{array}$ & $\begin{array}{l}1.0 \\
1.0\end{array}$ & $\begin{array}{l}35 \\
36\end{array}$ & $\begin{array}{l}35 \\
56\end{array}$ & $\begin{array}{l}36 \\
58\end{array}$ \\
\hline $\begin{array}{l}\text { Sulfate }^{b} \\
\text { Upstream } \\
\text { Downstream }\end{array}$ & $\begin{array}{l}3 \\
4\end{array}$ & $\begin{array}{l}1.0 \\
1.0\end{array}$ & $\begin{array}{l}116 \\
121\end{array}$ & $\begin{array}{l}118 \\
190\end{array}$ & $\begin{array}{l}121 \\
205\end{array}$ \\
\hline
\end{tabular}


Table 3.6 Statistical summary of she San Juan River water quality at the Shiprock UMTRA site, Now Mexico," February 25, 1993 (Concluded)

\begin{tabular}{|c|c|c|c|c|c|}
\hline \multirow[b]{2}{*}{ Constituent } & \multirow[b]{2}{*}{$\begin{array}{l}\text { Number of } \\
\text { samples }\end{array}$} & \multirow[b]{2}{*}{$\begin{array}{c}\text { Detection } \\
\text { limit }\end{array}$} & \multicolumn{3}{|c|}{$\begin{array}{c}\text { Observed concentrations } \\
\text { (mg/L) }\end{array}$} \\
\hline & & & Minimum & Median & Maximum \\
\hline $\begin{array}{l}\text { Strontium } \\
\text { Upstream } \\
\text { Downstream }\end{array}$ & $\begin{array}{l}3 \\
4\end{array}$ & $\begin{array}{l}0.01 \\
0.01\end{array}$ & $\begin{array}{l}0.82 \\
0.80\end{array}$ & $\begin{array}{l}0.83 \\
1.12\end{array}$ & $\begin{array}{l}0.85 \\
1.18\end{array}$ \\
\hline $\begin{array}{l}\text { Uranium } \\
\text { Upstream } \\
\text { Downstream }\end{array}$ & $\begin{array}{l}3 \\
4\end{array}$ & $\begin{array}{l}0.001 \\
0.001\end{array}$ & $\begin{array}{r}<0.001 \\
0.001\end{array}$ & $\begin{array}{l}0.001 \\
0.001\end{array}$ & $\begin{array}{l}0.002 \\
0.001\end{array}$ \\
\hline $\begin{array}{l}\text { Vanadium } \\
\text { Upstream } \\
\text { Downstream }\end{array}$ & $\begin{array}{l}3 \\
4\end{array}$ & $\begin{array}{l}0.01 \\
0.01\end{array}$ & $\begin{array}{l}0.09 \\
0.08\end{array}$ & $\begin{array}{l}0.09 \\
0.11\end{array}$ & $\begin{array}{l}0.09 \\
0.14\end{array}$ \\
\hline Radionuclides & & & & $(\mathrm{pCi} / \mathrm{L})$ & \\
\hline $\begin{array}{l}\text { Lead-210 } \\
\text { Upstream } \\
\text { Downstream }\end{array}$ & $\begin{array}{l}3 \\
4\end{array}$ & & $\begin{array}{l}2.1 \\
1.0\end{array}$ & $\begin{array}{l}2.6 \\
1.8\end{array}$ & $\begin{array}{l}3.3 \\
2.6\end{array}$ \\
\hline $\begin{array}{l}\text { Polonium-210 } \\
\text { Upstream } \\
\text { Downstream }\end{array}$ & $\begin{array}{l}3 \\
4\end{array}$ & & $\begin{array}{l}0.0 \\
0.0\end{array}$ & $\begin{array}{l}0.0 \\
0.3\end{array}$ & $\begin{array}{l}0.3 \\
1.1\end{array}$ \\
\hline $\begin{array}{l}\text { Radium-226 } \\
\text { Upstream } \\
\text { Downstream }\end{array}$ & $\begin{array}{l}3 \\
4\end{array}$ & & $\begin{array}{l}1.3 \\
1.5\end{array}$ & $\begin{array}{l}2.5 \\
1.8\end{array}$ & $\begin{array}{l}2.9 \\
1.9\end{array}$ \\
\hline $\begin{array}{l}\text { Thorium-230 } \\
\text { Upstream } \\
\text { Downstream }\end{array}$ & $\begin{array}{l}3 \\
4\end{array}$ & & $\begin{array}{l}0.1 \\
0.1\end{array}$ & $\begin{array}{l}0.2 \\
0.2\end{array}$ & $\begin{array}{l}0.3 \\
0.6\end{array}$ \\
\hline
\end{tabular}

anfiltered water samples.

b Statistically elevated above background at the 0.05 level of significance.

'Upstream locations: 546, 552, 554 (each location sampled one time).

dDownstream locations: 548, 549, 550, 551 (each location sampled one time).

${ }^{\ominus}$ Analyzed for, but not detected. 
where

$\mathrm{C}_{\mathrm{f}}=$ final concentration of a constituent in the final mixture

$\mathrm{Q}_{\mathrm{gw}}=$ ground water flow into the San Juan River $\left(\mathrm{ft}^{3} / \mathrm{s}\right)$

$C_{\text {gw }}=$ constituent concentration in ground water $(\mathrm{mg} / \mathrm{L})$

$Q_{r}=$ flow of the San Juan River $\left(\mathrm{ft}^{3} / \mathrm{s}\right)$

$C_{r}=$ concentration of the same constituent in the San Juan River (mg/L)

Initial concentrations taken from monitor well 736 (1993 water quality analysis) used in the calculation are uranium at $2.28 \mathrm{mg} / \mathrm{L}$ in ground water and $0.0005 \mathrm{mg} / \mathrm{L}$ in the San Juan River; nitrate concentrations at $175 \mathrm{mg} / \mathrm{L}$ in ground water and 0.05 $\mathrm{mg} / \mathrm{L}$ in the San Juan River; and sulfate concentrations at $14,600 \mathrm{mg} / \mathrm{L}$ in ground water and $187 \mathrm{mg} / \mathrm{L}$ in San Juan River water.

Using a ground water flow of $0.2 \mathrm{ft}^{3} / \mathrm{s}\left(0.006\right.$ cubic meters per second $\left.\left[\mathrm{m}^{3} / \mathrm{s}\right]\right)$ and the lowest recorded 7-day flow of the San Juan River since the construction of the Navajo Dam $\left(81 \mathrm{ft}^{3} / \mathrm{s}\left[2.3 \mathrm{~m}^{3} / \mathrm{s}\right]\right)$, the following concentrations were calculated for the potentially impacted San Juan River: uranium at $0.006 \mathrm{mg} / \mathrm{L}$, nitrate at 0.5 $\mathrm{mg} / \mathrm{L}$, and sulfate at $222 \mathrm{mg} / \mathrm{L}$. These concentrations are within the range of ambient San Juan River water quality. From this calculation, the impact of contaminated ground water from the floodplain on San Juan River water quality appears to be negligible. 


\subsection{EXPOSURE ASSESSMENT}

This section discusses and quantifies the potential exposures that could be incurred by current or future residents, recreational users, and others who use ground water or surface water contaminated by the Shiprock processing site. The methodology used here is consistent with the latest EPA guidance on exposure assessments (EPA, 1989a), which recommends an analysis based on the reasonable maximum exposure under both current and future land-use conditions. The reasonable maximum exposure is defined as the highest exposure that can be reasonably expected to occur at the site.

\subsection{EXPOSURE PATHWAYS}

Ground water contaminated by uranium processing at the Shiprock site is not used as a domestic or potable water supply. This includes the contaminated area in the San Juan River floodplain and contaminated ground water in the terrace alluvium area, although the areal and vertical extent of the terrace alluvium contamination is not fully defined. No points of ground water withdrawal from the floodplain alluvium, terrace alluvium, or the Mancos Shale exist within the site vicinity.

However, the potential exists for exposure to surface expressions of ground water on the San Juan River floodplain. A potential human secondary exposure pathway may be the consumption of meat or milk from livestock grazed and watered on the floodplain. Livestock may consume both the floodplain surface water contaminated by ground water and pasture grasses that become contaminated through the uptake of contaminants from ground water. Incidental access to the floodplain area by children or adults and subsequent direct contact with surface water bodies contaminated by ground water may create another human exposure pathway.

The NTUA point of water withdrawal from the San Juan River is near the site. This water intake is approximately $300 \mathrm{ft}(90 \mathrm{~m})$ upstream of the Route 666 bridge over the river, on the north side. As discussed in Section 3.5, the water intake does not appear to be affected by contaminants that may emanate from the site.

\subsubsection{Ground water exposure pathways for the floodplain}

Currently, ground water is not used for household purposes in the site vicinity. Although it is unlikely that ground water will be used in the future for household purposes because of the existing public water supply system, this risk assessment will assume hypothetical future use of ground water resources, including the use of ground water from the San Juan River floodplain for drinking, cooking, and bathing. Other uses typical of the region that could indirectly lead to human exposure include irrigation, livestock watering, and livestock grazing on the floodplain area Igrazing permits in the Shiprock region include the portion of the floodplain north and east of the former uranium processing site).

Figure 4.1 provides a conceptual model for potential floodplain ground water exposure pathways. 


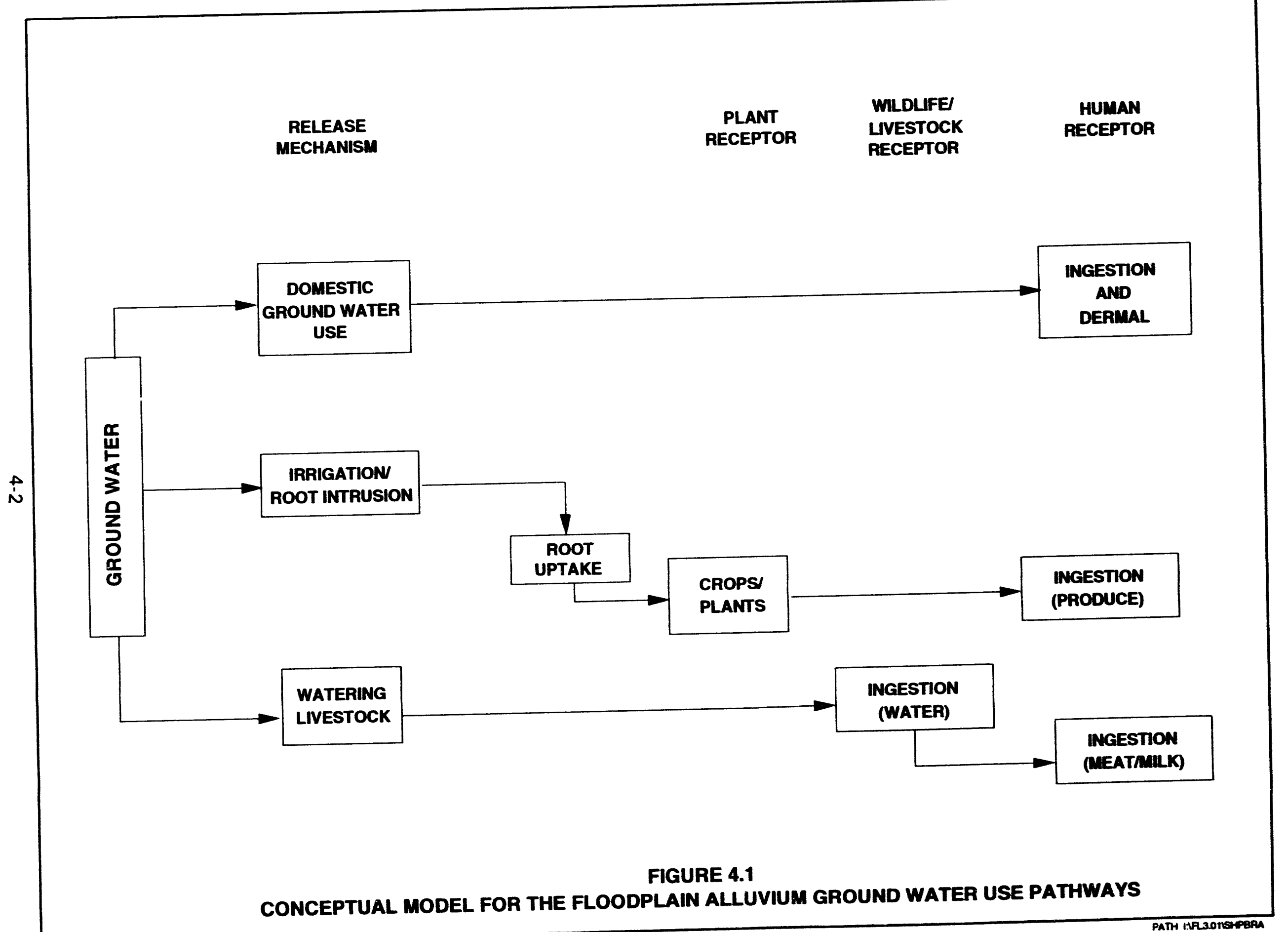




\subsubsection{Ground water exposure pathways for the terrace alluvium}

The only exposure pathway that is evaluated for the terrace alluvium ground water is drinking water ingestion, because it is the pathway with the highest intake for nonvolatile compounds. Because data on the terrace alluvium background ground water quality are not available, the areal and vertical extent of the aquifer contamination is not fully known, and the yield of the aquifer seems to be very low, it is not known if ground water is suitable for use as a drinking water resource. However, potential future beneficial use of the terrace alluvium ground water is evaluated, because it cannot be ruled out at this time.

\subsubsection{Surface water exposure pathways for the floodplain area}

This exposure scenario is considered because of potential access to the floodplain area, especially by children playing in summer and by domestic animals that may graze on the floodplain. Three contaminants of potential concern detected in pools of surface water on the floodplain (see Section 7.0 for a detailed discussion), (selenium, strontium, and uranium), were selected for a detailed evaluation of their potential to pose adverse health effects. Figure 4.2 provides a conceptual model for potential exposure pathways for the floodplain of the San Juan River below the Shiprock site.

\subsection{POTENTIALLY EXPOSED POPULATION}

The floodplain ground water pathways evaluate domestic ground water uses consistent with uses of a rural population of the region. The potentially exposed population includes Navajo infants (birth to 1 year old) and adults. These age groups were selected because toxicological responses are similar in these age groups, including recognition of sensitive subgroups for the contaminants of concern (infants); consistent intake to body weight ratios; and toxicokinetics.

For these same reasons, the terrace alluvium ground water pathway of drinking water ingestion is also evaluated for infants and adults.

Direct exposure to contaminated surface water in the floodplain is evaluated for children because they are likely to play in the floodplain and would receive higher exposures than adults. Secondary exposures, such as meat or milk ingestion from livestock grazed and watered on the floodplain, could occur in both children and adults.

Diabetics are a sensitive Navajo subpopulation. The type II (adult onset) diabetes rate among the Navajo population is reportedly 20 percent of the population over 20 years old and apparently is on an upward trend in regions of the Navajo Reservation (Hoy, 1993). Another sensitive subpopulation in the immediate site vicinity might consist of residents with a history of occupational exposure to uranium dust and radiation from the former Shiprock uranium ore mill and/or during uranıum minıng (TAC, 1993). Though this risk assessment does not quantitatively evaluate these subpopulations, diabetes could increase susceptibility to toxic 


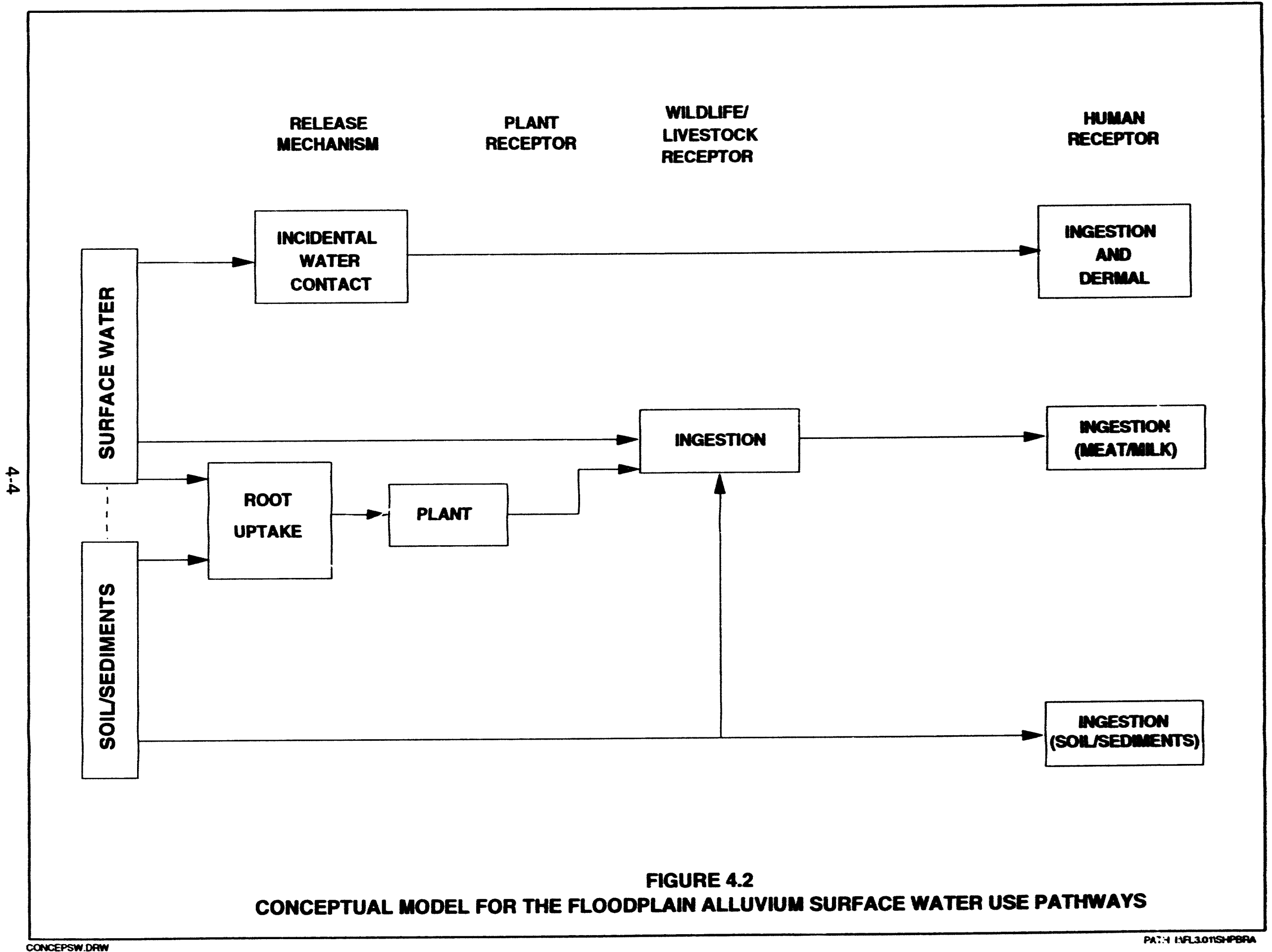


exposure from compromised renal function and increased drinking water ingestion. Previous occupational exposure could make that subpopulation more vulnerable to subsequent toxic exposures.

\subsection{EXPOSURE CONCENTRATIONS}

The exposure concentration of a contaminant in ground water is that concentration contacted by an individual over the period of exposure being considered. In this evaluation, the contaminant concentrations are assumed to be in a steady state, even though actual exposure concentrations are expected to fluctuate but eventually decrease with time because surface remediation is complete at the site. Nonetheless, they are reasonable estimates for chronic exposure soon after remediation (chronic exposure for noncarcinogens is considered to be a period of at least 7 years).

Exposure point concentrations used for the floodplain ground water-use scenario are the 95 percent upper confidence interval for the median contaminant concentrations, based on ground water data collected from monitor well 615 . With two exceptions, this well has consistently shown the highest levels of contamination through the past 8 years of monitoring. First, ammonium levels were consistently higher in well 608 than in 615; therefore, the ammonium median concentration was based on ground water data collected from monitor well 608 . Second, levels of antimony, arsenic, cadmium, lead-210, polonium-210, radium226, and thorium-230 measured in seven monitor wells in the immediate vicinity of the disposal cell $(608,609,610,611,613,614$, and 615) were combined to characterize these constituents' concentrations in the plume because of their low detectability. Exposure point concentrations for the floodplain alluvium are shown in Table 4.1.

Table 4.1 Exposure concentrations for the floodplain ground water

\begin{tabular}{cc}
$\begin{array}{c}\text { Contaminant of } \\
\text { potential concern }\end{array}$ & $\begin{array}{c}\text { Upper } 95 \text { percent confidence interval } \\
\text { estimate for the median } \\
\text { (mg/L) }\end{array}$ \\
\hline Antimony & 0.037 \\
Arsenic & 0.03 \\
Cadmium & 0.005 \\
Magnesium & 2,540 \\
Manganese & 9.38 \\
Nitrate & 4,220 \\
Selenium & 0.26 \\
Sodium & 3,630 \\
Strontium & 12.2 \\
Sulfate & 15,000 \\
Uranium & 3.0 \\
\hline
\end{tabular}


Exposure point concentrations for nitrate and sulfate in the terrace ground water are the maximum observed concentrations in terrace wells which occurred in monitor well 727 (Table 4.2). Uranium concentration is represented by the maximum observed concentration in ground water from monitor well 600.

Table 4.2 Exposure concentrations for the terrace alluvium ground water

\begin{tabular}{|c|c|c|}
\hline Constituent & $\begin{array}{c}\text { Observed } \\
\text { concentration } \\
(\mathrm{mg} / \mathrm{L})\end{array}$ & Comments \\
\hline Nitrate & 2,310 & $\begin{array}{l}\text { Concentration in downgradient monitor well } \\
727 \text {, measured in } 1993 \text {. }\end{array}$ \\
\hline Sulfate & 18,100 & $\begin{array}{l}\text { Concentration in downgradient monitor well } \\
72.7 \text {, measured in } 1993 \text {. }\end{array}$ \\
\hline Uranium & 1.57 & $\begin{array}{l}\text { Maximum measured concentration in } \\
\text { downgradient monitor well } 600 \text {. }\end{array}$ \\
\hline
\end{tabular}

For the human exposure pathway associated with ingestion of meat and milk from livestock grazed and watered on the San Juan River floodplain, observed maximum values for surface water and sediment data were used. The median value of the contaminant concentrations in ground water was used to estimate pasture grass root uptake (Table 4.3).

Table 4.3 Exposure concentrations for the floodplain surface water and sediments

\begin{tabular}{lccc}
\hline $\begin{array}{c}\text { Contaminant of } \\
\text { potential } \\
\text { concern }\end{array}$ & $\begin{array}{c}\text { Surface water } \\
\text { concentration } \\
\text { Cw } \\
(\mathbf{m g} / \mathrm{L})\end{array}$ & $\begin{array}{c}\text { Ground water } \\
\text { concentration (root uptake) } \\
\mathbf{C W}_{\mathbf{w}} \\
(\mathbf{m g} / \mathrm{L})\end{array}$ & $\begin{array}{c}\text { Sediment } \\
\text { concentration } \\
\text { (mg/kg) }\end{array}$ \\
\hline Selenium & 0.035 & 0.12 & 4.2 \\
Strontium & 7.34 & 9.79 & 1620 \\
Uranium & 1.1 & 1.30 & 44 \\
\hline
\end{tabular}

$\mathrm{CW}$ - contaminant concentration in ground water.

$\mathrm{mg} / \mathrm{kg}$ - milligrams per kilogram. 


\subsection{ESTIMATION OF INTAKE}

Individuals within the population of future residents are expected to vary with respect to water consumption habits, stable body weight, and length of time they may reside in the potential contamination zone. Consequently, health risks associated with ground water consumption will vary among members of the population. Nevertheless, to describe the potential risks to the future population, daily water intake, body weight, and residency time were incorporated into this assessment using the default values according to the standard EPA procedure (EPA, 1989a).

The exposure routes and potentially exposed populations that are quantitatively evaluated are summarized in Table 4.4. In addition to exposure routes and potentially exposed populations, intakes are calculated separately for noncancerous (noncarcinogenic) and cancerous (carcinogenic) health effects. Contaminants such as arsenic and uranium are associated with both noncarcinogenic effects and cancer, so they appear under both carcinogenic and noncarcinogenic intake estimations. Carcinogenic intakes for radionuclides are cumulative and are estimated for a lifetime exposure, whereas noncarcinogenic intakes are estimated as a dose per day.

Table 4.4 Quantitatively evaluated exposure routes

\begin{tabular}{|c|c|c|c|c|}
\hline \multirow[b]{2}{*}{ Source } & \multirow[b]{2}{*}{ Exposure route } & \multicolumn{3}{|c|}{ Potentially exposed population } \\
\hline & & Intant & Child & Adult \\
\hline $\begin{array}{l}\text { Floodplain } \\
\text { ground water }\end{array}$ & $\begin{array}{l}\text { Drinking water ingestior, } \\
\text { Dermal contact (bathing) } \\
\text { Ground water-irrigated produce } \\
\text { ingestion }\end{array}$ & $x$ & & $\begin{array}{l}x \\
x \\
x\end{array}$ \\
\hline $\begin{array}{l}\text { Terrace } \\
\text { alluvium ground } \\
\text { water }\end{array}$ & Drinking water ingestion & $x$ & & $x$ \\
\hline $\begin{array}{l}\text { Floodplain } \\
\text { surface water }\end{array}$ & $\begin{array}{l}\text { Incidental water ingestion } \\
\text { Incidental sediment ingestion } \\
\text { Dermal contact (wading) } \\
\text { Meat ingestion } \\
\text { Milk ingestion }\end{array}$ & & $\begin{array}{l}x \\
x \\
x\end{array}$ & $\begin{array}{l}x \\
x\end{array}$ \\
\hline
\end{tabular}




\subsubsection{Floodplain ground water exposure routes}

\section{Drinking water ingestion}

Drinking water ingestion is generally the most significant exposure route for ground water contaminated with metals and other nonvolatile compounds. For this evaluation, drinking water consumption includes water consumed in drinking as well as water used to prepare food (e.g., reconstituted juices, soup, rice, beans). The assumptions and equations used to estimate intakes from drinking water ingestion are shown in Table 4.5.

Under the Navajo land tenure system, when a family has a grazing permit, the family usually resides on its land for its lifetime. Because Shiprock is a small urban center and there are no residence data for the Navajos in the vicinity of Shiprock, a chronic (i.e., at least 7-year) exposure duration is assumed for noncarcinogens and 50 years for carcinogens.

\section{Dermal absorption}

Dermal absorption is the process by which chemicals coming into contact with the skin become absorbed into the blood vessels near the skin surface. Some compounds are absorbed easily in this manner, though metals do not possess the chemical properties that are conducive to skin absorption.

To evaluate this exposure route, a screening calculation was performed to determine whether the contribution from dermal absorption would be significant compared to the drinking water pathway for the contaminants of concern. Because chemical-specific absorption factors are not available for these contaminants, they are assumed to absorb across the skin at the same rate as water. This assumption will likely overestimate any potential contribution from dermal absorption.

The results of the screening are given in Table 4.5. Based on these results, the dermal absorption exposure route is eliminated from more detailed evaluation, because it contributed less than 1 percent of the total dose from drinking water. However, it should be noted that the dermal dose is an absorbed dose whereas the drinking water dose is an administered dose, only a fraction of which would become absorbed.

\section{Ingestion of ground water-irrigated produce}

This exposure route was also evaluated for its relative significance to the drinking water ingestion route. The results of the screening calculation are shown in Table 4.6. The assumptions for this evaluation will likely overestimate the potential for exposure from this route, because it is assumed that all consumed garden produce would be taken from this ground water-irrigated garden. The results of this screening show that for all contaminants of concern except strontium, exposure through ingestion of garden vegetables and fruit irrigated with contaminated ground water can be eliminated from more detailed evaluation 
Table 4.5 Exposure dose calculations and equation definitions for ground water ingestion and dermal contact, Shiprock, New Mexico, site

\section{Equation definitions for exposure dose calculations}

\section{Ingestion of ground water}

\section{Chemicals}

Chronic daily intake $(\mathrm{mg} / \mathrm{kg}$-day)

$$
=\frac{C W \times I R W \times E F \times E D}{B W \times A T}
$$

\section{Radionuclides}

Lifetime intake (pCi/lifetime)

$=\quad C W \times I R W \times E F \times E D$

Dermal contact with ground water

\section{Chemicals}

Chronic daily intake $(\mathrm{mg} / \mathrm{kg}$-day)

\section{Radionuclides}

Lifetime intake (pCi/lifetime)

\author{
$=\frac{(C W \times S A \times P C \times C f) \times E T \times E F \times E D}{B W \times A T}$
}

$=C W \times S A \times P C \times C f \times E T \times E F \times E D$

Where

Cw Contaminant concentration in ground water (upper 95 percent confidence interval estimate for the median concentration from wells $608,609,610,611,613,614$, or 615$)(\mathrm{mg} / \mathrm{L}$ or $\mathrm{pCi} / \mathrm{L})$.

IRw Ingestion rate for water (L/day) (2. L/day for an adult, $0.64 \mathrm{~L} /$ day for an infant).

EF Exposure frequency (350 days/year).

ED Exposure duration 17 years for an adult and 1 year for an infant for noncarcinogens; 50 years for carcinogens).

BW Body weight $(70 \mathrm{~kg}$ for an adult, $4 \mathrm{~kg}$ for an infant).

AT Averaging time (365 days $\times$ ED for noncarcinogens, 365 days $\times 70$ years for carcinogens).

SA Skin surface area $\left(19,400 \mathrm{~cm}^{2}\right)$

Pc Dermal permeability constant $10.001 \mathrm{~cm} /$ hour).

Cf Conversion factor $\left(0.001 \mathrm{~L} / \mathrm{cm}^{3}\right)$.

ET Exposure time $(0.2$ hour/day). 
Table 4.5 Exposure dose calculations and equation definitions for the floodplain ground water ingestion and dermal contact, Shiprock, New Mexico, site (Concluded)

\begin{tabular}{|c|c|c|c|c|}
\hline \multirow{2}{*}{$\begin{array}{c}\text { Contaminant of } \\
\text { concern }\end{array}$} & \multirow{2}{*}{$\begin{array}{c}\mathrm{Cw} \\
(\mathrm{mg} / \mathrm{L})\end{array}$} & \multicolumn{2}{|c|}{$\begin{array}{c}\text { Floodplain ground water exposure } \\
\text { doses } \\
\text { (mg/kg-day) }\end{array}$} & \multirow{2}{*}{$\frac{\text { Dermal }}{\text { Ingestion }}$} \\
\hline & & Ingestion & Dermal contact & \\
\hline \multicolumn{5}{|c|}{ Noncarcinogenic effects } \\
\hline Antimony & 0.037 & $1 \mathrm{E}-03$ & $2 E-06$ & 0.002 \\
\hline Arsenic & 0.03 & $8 E-04$ & $2 E-06$ & 0.002 \\
\hline Cadmium & 0.005 & $1 E-04$ & $3 E-07$ & 0.002 \\
\hline Magnesium & 2540 & $7 E+01$ & $1 E-01$ & 0.002 \\
\hline Manganese & 9.38 & $3 E-01$ & $5 E-04$ & 0.002 \\
\hline Nitrate & 4220 & $\begin{array}{c}1 E+02 \\
6 E+02^{a}\end{array}$ & $2 E-01$ & 0.002 \\
\hline Selenium & 0.26 & 7E-03 & $1 \mathrm{E}-05$ & 0.002 \\
\hline Sodium & 3630 & $1 E+02$ & $2 E-01$ & 0.002 \\
\hline Strontium & 12.2 & $3 E-01$ & $6 \mathrm{E}-04$ & 0.002 \\
\hline Sulfate & 15000 & $\begin{array}{l}4 E+02 \\
2 E+03^{a}\end{array}$ & $8 E-01$ & 0.002 \\
\hline Uranium & 3.0 & $8 \mathrm{E}-02$ & $2 E-04$ & 0.002 \\
\hline \multicolumn{5}{|l|}{ Carcinogenic effects } \\
\hline Arsenic & 0.03 & $6 \mathrm{E}-04$ & $1 \mathrm{E}-06$ & 0.002 \\
\hline Uranium $^{b}$ & $2058^{c}$ & $7 E+07^{d}$ & $1 E+05^{d}$ & 0.001 \\
\hline
\end{tabular}

axposure dose calculated for an infant (aged 0 to 1 year).

Uranium-234 and uranium-238 combined.

cUnits are in picocuries per liter; $1 \mathrm{mg}$ uranium is assumed to equal $686 \mathrm{pCi}$.

dUnits are in picocuries per lifetime.

kg - kilogram.

$\mathrm{cm}^{2}$ - square centimeter.

$\mathrm{cm}^{3}$ - cubic centimeter.

$\mathrm{mg} / \mathrm{kg}$-day - milligrams per kilogram per day. 
Table 4.6 Exposure dose calculations for ground water-irrigated garden produce ingestion in future hypothetical adult scenarios, San Juan floodplain, Shiprock, New Mexico, site

\section{Equation definitions for exposure dose calculations}

Ingestion of garden produce irrigated with ground water

Chemicals

Chronic daily intake (mg/kg-day)

$=\quad \mathrm{CW} \times \mathrm{Kd} \times \mathrm{Bv}$ or $\mathrm{Br}^{\mathrm{a}} \times \mathrm{DF} \times \mathrm{IRp} \times \mathrm{FI} \times \mathrm{EF} \times \mathrm{ED}$

Radionuclides

Lifetime intake (pCi/lifetime)

$=\mathrm{Cw} \times \mathrm{Kd} \times \mathrm{Bv}$ or $\mathrm{Br}^{\mathrm{a}} \times \mathrm{DF} \times \mathrm{IRp} \times \mathrm{FI} \times \mathrm{EF} \times \mathrm{ED}$

Where

Cw Contaminant concentration in ground water (upper 95 percent confidence level of the median of data from wells 608 , $609,610,611,613,614$, or 615$)(\mathrm{mg} / \mathrm{L}$ or $\mathrm{pCi} / \mathrm{L})$.

Kd Soil-water partition coefficient (L/kg) (Baes et al., 1984).

Bv Soil-to-plant concentration ratio for vegetative portions of plants (unitless) (Baes et al., 1984).

$\mathrm{Br}$ Soil-to-plant concentration ratio for reproductive portions (fruits, tubers) of plants (unitless) (Baes et al., 1984).

DF Dry weight fraction of plant (0.066; unitless).

IRp Ingestion rate for garden produce $(0.05 \mathrm{~kg} /$ day for vegetative parts; $0.03 \mathrm{~kg} /$ day for reproductive parts).

FI Fraction of garden produce ingested from contaminated source (1.0; unitless).

$\mathrm{EF}$ Exposure frequency (350 days/year).

ED Exposure duration ( 7 years for an adult for noncarcinogens; 50 years for carcinogens).

BW Body weight $(70 \mathrm{~kg}$ for an adult).

AT Averaging time $(365$ days $\times$ ED for noncarcinogens; 365 days $\times 70$ years for carcinogens). 


\begin{tabular}{|c|c|c|c|c|c|c|c|c|}
\hline \multirow{9}{*}{ 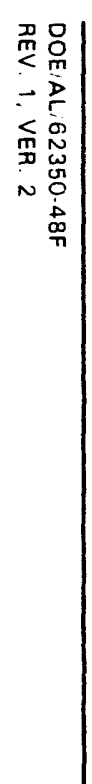 } & \multirow{3}{*}{$\begin{array}{c}\text { Table } 4.6 \text { Ex } \\
\mathrm{sc} \\
\begin{array}{c}\text { Contaminant of } \\
\text { concern }\end{array} \\
\end{array}$} & \multicolumn{7}{|c|}{$\begin{array}{l}\text { Exposure dose calculations for ground water-irrigated garden produce ingestion in future hypothetical adult } \\
\text { scenarios, San Juan floodplain, Shiprock, New Mexico, site (Concluded) }\end{array}$} \\
\hline & & & & & & $\begin{array}{r}\text { Garden pro } \\
\text { expos } \\
\text { (mg }\end{array}$ & $\begin{array}{l}e \text { ingestion } \\
\text { doses } \\
\text { dayl }\end{array}$ & $\begin{array}{l}\text { Total produce } \\
\text { ingestion }\end{array}$ \\
\hline & & $\underset{(m g / L)}{C w}$ & $\begin{array}{l}K d \\
(L / k g)\end{array}$ & Bv & $\mathrm{Br}$ & $\begin{array}{l}\text { Vegetative } \\
\text { parts }\end{array}$ & $\begin{array}{l}\text { Reproductive } \\
\text { parts }\end{array}$ & $\begin{array}{l}\text { Water } \\
\text { ingestion }\end{array}$ \\
\hline & Noncarcinogenic & ects & & & & & & \\
\hline & Antimony & 0.037 & 45 & 0.20 & 0.03 & $2 E-05$ & $1 E-06$ & 0.02 \\
\hline & Arsenic & 0.03 & 200 & 0.04 & 0.006 & $1 E-05$ & $1 E-06$ & 0.01 \\
\hline & Cadmium & $<0.005$ & 6.5 & 0.55 & 0.15 & $8 E-07$ & $1 E-07$ & 0.007 \\
\hline & Magnesium & 2540 & 4.5 & 1.0 & 0.55 & $5 \mathrm{E}-01$ & $2 \mathrm{E}-01$ & 0.01 \\
\hline & Manganese & 9.38 & 65 & 0.25 & 0.05 & $7 E-03$ & $8 E-04$ & 0.03 \\
\hline \multirow{9}{*}{$\frac{P}{\stackrel{D}{N}}$} & Nitrate & 4220 & 0.01 & 30 & 30 & $6 \mathrm{E}-02$ & $3 E-02$ & 0.0009 \\
\hline & Selenium & 0.26 & 300 & 0.025 & 0.025 & $9 E-05$ & $5 E-05$ & 0.02 \\
\hline & Sodium & 3630 & 100 & 0.075 & 0.055 & $1 E+00$ & $5 E-01$ & 0.02 \\
\hline & Strontium & 12.2 & 35 & 2.5 & 0.25 & $5 E-02$ & $3 E-03$ & 0.18 \\
\hline & Sulfate & 15,000 & 7.5 & 0.5 & 0.5 & $3 E+00$ & $2 E+00$ & 0.01 \\
\hline & Uranium & 3.0 & 450 & 0.0085 & 0.004 & $5 E-04$ & $1 E-04$ & 0.008 \\
\hline & Carcinogenic eff & & & & & & & \\
\hline & Arsenic & 0.03 & 200 & 0.04 & 0.006 & $1 E-06$ & $1 E-07$ & 0.002 \\
\hline & Uranium & $2058^{b}$ & 450 & 0.0085 & 0.004 & $5 E+05^{c}$ & $1 E+05^{c}$ & 0.009 \\
\hline 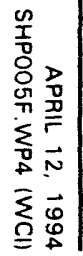 & $\begin{array}{l}{ }^{a} \text { Exposure doses } \\
{ }^{b} \text { Picocuries per } \\
\text { CPicocuries per }\end{array}$ & $\begin{array}{l}\text { to consumpt } \\
\text { me. }\end{array}$ & vegeta & itions a & reprod & ns of garde & ıce are calcu & ately. \\
\hline
\end{tabular}


because this exposure route contributes less than 3 percent of the total dose from drinking water. Potential strontium exposure at these levels is not expected to cause adverse health effects in humans.

\section{Ingestion of meat or milk from ground water-fed livestock}

These pathways were eliminated from further consideration, because the concentrations of nitrate and sulfate are so high that livestock could not survive chronic ingestion of the water. If the livestock cannot consume the water, no potential exists for bioaccumulation or transfer of the ingested contaminants to meat or milk. Further evaluation of the direct toxicity to livestock is presented in Section 7.0. This pathway is evaluated in Section 4.4.3 for floodplain surface water, where nitrate concentrations are not so high.

\subsubsection{Terrace alluvium ground water exposure routes}

Drinking water ingestion is generally the most significant exposure route for ground water contaminated with metals and other nonvolatile chemical compounds. For this evaluation, drinking water consumption includes water consumed for drinking and water used in food preparation. Due to the lack of background ground water quality information, contaminants of concern for the terrace alluvium ground water could not be determined. However, three constituents clearly associated with uranium processing that are highly elevated compared to regional waters were selected for the pathway screening: nitrate, sulfate, and uranium. As can be seen in Tables 4.5 and 4.6 , the relative pathway contribution for these contaminants is greater than 99 percent from drinking water ingestion. The exposure assessment of drinking water intake of terrace alluvium ground water is shown in Table 4.7. This exposure pathway is further evaluated in Section 6.0.

\subsubsection{Floodplain surface water exposure routes}

The pathways that may occur on the floodplain include incidental ingestion of surface water and sediments while wading, dermal contact with surface water, and consumption of contaminated meat and milk from livestock grazed and watered on the floodplain.

For this evaluation, it is assumed that incidental ingestion of sediments and water from the surface water bodies identified on the floodplain area, as well as dermal contact with this water, would most likely occur during summer. Children aged 6 to 12 years are considered the subpopulation most likely to play on the floodplain.

\section{Incidental ingestion of surface water}

Incidental surface water ingestion could occur while children play on the floodplain area. Durıng this play, it is assumed that children may incidentally ingest a few tablespoons of water. It is further assumed that children would visit the floodplain every day during the summer as well as visiting it on weekends during 3 other months of the year. The results for this exposure route are presented in Table 4.8. 
Table 4.7 Exposure dose calculations for hypothetical adult scenario of ground water ingestion from the terrace alluvium, Shiprock, New Mexico, site

\begin{tabular}{lccc}
\hline \multicolumn{1}{c}{ Constituent } & $\begin{array}{c}\text { Exposure point } \\
\text { concentration } \\
(\mathbf{m g} / \mathrm{L})\end{array}$ & Well location & $\begin{array}{c}\text { Estimated } \\
\text { intake } \\
\text { (mg/kg-day) }\end{array}$ \\
\hline Noncarcinogens & 2,310 & 727 & $6 \mathrm{E}+01$ \\
Nitrate & 18,100 & 727 & $4 \mathrm{E}+02^{\mathrm{b}}$ \\
Sulfate & 1.57 & $6 \mathrm{E}+02$ \\
& & 600 & $3 \mathrm{E}+03^{\mathrm{b}}$ \\
Uranium & & & $4 \mathrm{E}-02$ \\
Carcinogens & $1,077^{\mathrm{d}}$ & 600 & \\
Uranium $^{\mathrm{c}}$ & & & $4 \mathrm{E}+07^{\mathrm{e}}$ \\
\hline
\end{tabular}

a Equation definitions used to estimate human intake of the constituent through ingestion of the terrace alluvium ground water are the same as those presented in Table 4.5.

${ }^{b}$ Exposure dose calculated for an infant (aged 0 to 1 year).

CUranium-234 and uranium-238 combined; $1 \mathrm{mg}$ uranium is assumed to equal $686 \mathrm{pCi}$.

dPicocuries per liter.

epicocuries per lifetime.

\section{Dermal contact with surface water}

For the same scenario presented above, it is assumed that children's arms and legs will come into contact with surface water that has pooled in the floodplain. This leads to a potential exposure route from dermal absorption, although metals are generally not well absorbed across the skin. Because chemical-specific absorption factors are not available for these contaminants, it was assumed that they are absorbed across the skin at the same rate as water. This assumption is highly likely to overestimate any potential contribution from dermal absorption. The results for this pathway are presented in Table 4.8. This table shows that contributions from dermal absorption are approximately 1 percent of the incidental water ingestion pathway for the selected contaminants of concern. This ratio may slightly underestimate relative dermal contribution since the dermal dose is an absorbed dose whereas the ingested dose is an administered dose, only a fraction of which would becorne absorbed. 
Table 4.8 Exposure dose calculations for hypothetical incidental surface water ingestion and dermal contact by children on the floodplain. Shiprock. New Mexico, site

\section{Equation definitions for exposure dose calculations}

Incidental ingestion of surface water from the floodplain

Noncarcinogens

Chronic daily intake $(\mathrm{mg} / \mathrm{kg}$-day $)=\frac{C W \times \operatorname{RW} \times E F \times E D}{B W \times A T}$

Incidental dermal contact with surface water

Noncarcinogens

Chronic daily absorbed dose

(mg/kg-day)

$=$

$\mathrm{CW} \times \mathrm{Sa} \times \mathrm{PC} \times \mathrm{CF} \times \mathrm{ET} \times \mathrm{EF} \times \mathrm{ED}$ BW $\times$ AT

Where

CW Contaminant concentration in surface water bodies (the highest determined concentration at the floodplain specified location) (mg/L).

IRw Ingestion rate for water (L/day) $10.05 \mathrm{~L} /$ day for children aged 6 to 12 years).

EF Exposure frequency (days/year) 13 months per year during 7 days per week $=90$ days, and 3 months per year during weekends $=24$ days; total incidental exposure frequency equals 114 days per year).

ED Exposure duration $(7$ years for children aged 6 to 12 years playing on the floodplain area).

BW Body weight $(38.3 \mathrm{~kg}$ for children aged 6 to 12 years; 90 th percentile body weight for 9- to 10-year old male child).

AT Averaging time (365 days $\times$ ED).

Sa Skin surface area available to dermal exposure $1497 \mathrm{~cm}^{2}$ for children aged 6 to 12 years; calculated using 50 th percentile: hands $-57 \mathrm{~cm}^{2}$; arms $-130 \mathrm{~cm}^{2}$; legs $310 \mathrm{~cm}^{2}$ ) (EPA, 1989a).

Pc Dermal permeability constant $10.001 \mathrm{~cm} / \mathrm{hr}$.

Cf Conversion factror $\left.10.001 \mathrm{~L} / \mathrm{cm}^{3}\right)$.

ET Exposure time $i 1$ hour per dayl. 
Table 4.8 Exposure dose calculations for hypothetical incidental surface water ingestion and dermal contact by children on the floodplain. Shiprock, New Mexico, site (Concluded)

\begin{tabular}{|c|c|c|c|c|c|}
\hline \multirow{2}{*}{$\begin{array}{c}\text { Contaminant of } \\
\text { potential } \\
\text { concern }\end{array}$} & \multirow[b]{2}{*}{$\begin{array}{c}C w \\
(m g / L)\end{array}$} & \multirow{2}{*}{$\begin{array}{c}\text { Surface water } \\
\text { bodies location } \\
\text { ID }\end{array}$} & \multicolumn{2}{|c|}{$\begin{array}{l}\text { Exposure doses } \\
\text { (mg/kg-day) }\end{array}$} & \multirow[b]{2}{*}{$\frac{\text { Dermal }}{\text { Ingestion }}$} \\
\hline & & & Ingestion & $\begin{array}{l}\text { Dermal } \\
\text { contact }\end{array}$ & \\
\hline Selenium & 0.035 & 659 & $1 E-05$ & 1E-07 & 0.01 \\
\hline Strontium & 7.34 & 659 & $3 E-03$ & $3 E-05$ & 0.01 \\
\hline Uranium & 1.1 & 660 & $5 E-04$ & $5 E-06$ & 0.01 \\
\hline
\end{tabular}

${ }^{8}$ Refer to Section 7.0 for a description of surface water body locations. 
Table 4.9 Exposure dose calculations and equation definitions for hypothetical incidental ingestion of sediments by children on the floodplain at the Shiprock. New Mexico, site

Equation definitions for exposure dose calculations

Incidental ingestion of sediments in the floodplain area

Noncarcinogens

Chronic daily intake $(\mathrm{mg} / \mathrm{kg}$-day)

Chronic dally intake img/kg-dayl.

\author{
$=\frac{\text { Cs } \times \text { Csf } \times I R s \times F I \times E F \times E D}{B W \times A T}$
}

Where

Cs Contaminant concentration in sediments (the highest determined concentration in the floodplain soil at specified location) $(\mathrm{mg} / \mathrm{kg})$.

Csf Conversion factor $\left(10^{-6} \mathrm{mg} / \mathrm{kg}\right)$ (EPA, 1989a).

IRs Ingestion rate for sediments (100 mg/day) (EPA, 1989a).

FI Fraction ingested from sediments (1.0; unitless).

EF Exposure frequency (days/year) $(3$ months per year during 7 days per week $=90$ days, and 3 months per year during weekends $=24$ days; total incidental exposure frequency equals 114 days per year).

ED Exposure duration 17 years for children aged 6 to 12 years playing in the floodplain area).

BW Body weight $(38.3 \mathrm{~kg}$ for children aged 6 to 12 years; 90 th percentile body weight for 6- to 12-year-old male child).

AT Averaging time ( 365 days $\times$ ED).

\begin{tabular}{lcccc}
$\begin{array}{c}\text { Contaminant of } \\
\text { potential concern }\end{array}$ & $\begin{array}{c}\text { Cs } \\
(\mathbf{m g} / \mathbf{k g})\end{array}$ & $\begin{array}{c}\text { Sampling location } \\
\mathbf{1 0}^{\text {a }}\end{array}$ & $\begin{array}{c}\text { Contaminant intake } \\
\text { from ingested } \\
\text { sediments } \\
\text { (mg/kg-day) }\end{array}$ & $\begin{array}{c}\text { Sediment } \\
\text { ingestion }\end{array}$ \\
\hline Selenium & 4.2 & 659 & $3 \mathrm{E}-06$ & $\begin{array}{c}\text { Water } \\
\text { ingestion }\end{array}$ \\
Strontium & 1620 & 659 & $1 \mathrm{E}-03$ & 0.2 \\
Uranium & 44 & 659 & $4 \mathrm{E}-05$ & 0.4 \\
\hline
\end{tabular}

aRefer to Section 7.0 for a description of sediment sampling locations.

$\mathrm{mg} / \mathrm{kg}$ - milligrams per kilogram. 


\section{Incidental ingestion of sediments}

The third exposure route evaluated for children playing in the floodplain is incidental sediment ingestion. The equation and assumptions for the exposure route are shown on Table 4.9. When this exposure route is compared to incidental ingestion of surface water, the relative contribution is 24 percent for selenium, 43 percent for strontium, and 8 percent for uranium. Therefore, incidental ingestion of surface water and sediments is further evaluated in Section 6.0 for potential exposure to children playing on the floodplain.

\section{Ingestion of meat and milk from livestock grazed and watered on the floodplain}

These pathways are considered because a grazing permit has been issued for the floodplain below the site. Moreover, many residents living near the site keep livestock that may consume surface water and pasture grasses from the floodplain.

For this exposure pathway evaluation, concentrations of selected contaminants of concern in pasture grasses were determined assuming root intrusion into shallow ground water and pasture grass uptake of these constituents. The method used to estimate plant tissue concentrations of the contaminants of concern is described in detail in Section 7.0. The median concentrations of a contaminant in ground water from all wells installed within the entire floodplain are used for this evaluation. Siteand chemical-specific soil-water partition coefficient $(\mathrm{Kd})$ values are calculated for each sampling location as the ratio of measured contaminant concentration in the sediments to the measured contaminant concentration in the floodplain surface water bodies. These results are summarized in Tables 4.10 and 4.11 .

It is assumed that livestock grazing on the floodplain will drink water and will ingest sediments contaminated at the levels measured at identified surface locations. Table 4.12 summarizes the results of the potential human intake of selected contaminants of concern due to ingestion of meat and milk from livestock grazed and watered on the floodplain. This human exposure pathway is further evaluated in Section 6.0. 
Table 4.10 Kd values for selected contaminants of concern based on sediment and surface water concentrations measured on the floodplain. Shiprock. New Mexico, site

\begin{tabular}{|c|c|c|c|c|c|c|}
\hline \multirow{3}{*}{$\begin{array}{c}\text { Contaminant } \\
\text { of potential } \\
\text { concern }\end{array}$} & \multicolumn{5}{|c|}{ Wet area below } & \multirow{3}{*}{$\begin{array}{c}\text { Average } \\
\text { chemical-specific } \\
\text { Kd values } \\
\text { (L/kg) } \\
\end{array}$} \\
\hline & \multicolumn{2}{|c|}{$\begin{array}{l}\text { Drainage canal } \\
\text { location } 10^{\circ}\end{array}$} & \multicolumn{2}{|c|}{$\begin{array}{c}\text { Stagnant pools } \\
\text { location } 10^{\mathrm{a}}\end{array}$} & \multirow{2}{*}{$\begin{array}{c}\text { Seep } 425 \\
\frac{\text { location } 10^{\circ}}{659}\end{array}$} & \\
\hline & 655 & 656 & 660 & 661 & & \\
\hline Selenium & 1000 & .. & .. & .. & 120 & 560 \\
\hline Strontium & 81.8 & 117.8 & 97.9 & 32.2 & 220.7 & 110 \\
\hline Uranium & 137.5 & 87.9 & 20 & 17.9 & 63.8 & 66 \\
\hline
\end{tabular}

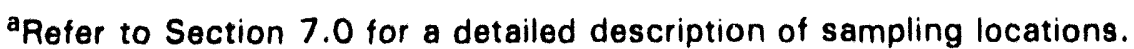

Table 4.11 Estimated concentrations of selected contaminants of concern in pasture grasses on the San Juan River floodplain, Shiprock, New Mexico, site

\begin{tabular}{|c|c|c|c|c|c|c|}
\hline $\begin{array}{c}\text { Contaminant } \\
\text { of potential } \\
\text { concern }\end{array}$ & $\begin{array}{c}C w \\
(\mathrm{mg} / \mathrm{L})^{\mathrm{a}}\end{array}$ & $\begin{array}{c}\text { Location } \\
\text { ID }\end{array}$ & $\begin{array}{c}\text { Kd } \\
(\mathrm{L} / \mathbf{k g})^{b}\end{array}$ & $\begin{array}{c}\text { Estimated soil } \\
\text { concentration } \\
\text { (Cs) }^{c} \\
\text { (mg/kg DW) }\end{array}$ & Bv & $\begin{array}{c}\text { Estimated } \\
\text { concentration in } \\
\text { vegetative portions } \\
\text { of plants }(\mathrm{Cp})^{\mathrm{d}} \\
\text { (mg/kg DW) }\end{array}$ \\
\hline Selenium & 0.12 & $607-630$ & 560 & 67 & 0.025 & 1.7 \\
\hline Strontium & 9.79 & 607.630 & 110 & 1080 & 2.5 & 2690 \\
\hline Uranium & 1.30 & 607.630 & 66 & 86 & 0.0085 & 0.73 \\
\hline
\end{tabular}

${ }^{a} \mathrm{CW}$ values represent the median of ground water concentrations from all wells in the San Juan River floodplain for 1986-1993.

${ }^{b} \mathrm{Kd}$ values are based on calculated mean values for sediment/surface water concentrations measured at the locations shown in Table 4.10.

${ }^{c}$ Concentration in soil $(\mathrm{Cs})=\mathrm{Cw} \times \mathrm{Kd}$.

${ }^{\mathrm{d}}$ Concentration in plants $(\mathrm{Cp})=\mathrm{Cs} \times \mathrm{Bv}$.

DW - dry weight.

$\mathrm{mg} / \mathrm{kg}$ - milligrams per kilogram 
Table 4.12 Exposure dose calculations for future hypothetical adult meat and milk consumption from cattle grazed and watered on the San Juan River floodplain, Shiprock, New Mexico, site

\section{Equation definitions for exposure dose calculations}

Ingestion of contaminated meat from cattle grazed on pasture grasses and fed with the floodplain surface water bodies

Noncarcinogens

Chronic daily intake $(\mathrm{mg} / \mathrm{kg}$-day

Radionuclides

Lifetıme intake (pCi/lifetime)

$$
\begin{aligned}
& =\frac{C b \times \mid R b \times F I \times E F \times E D}{B W \times A T} \\
& C b=F b((C p \times Q p)+(Q s \times C s)+Q w \times C w)]
\end{aligned}
$$

$=\quad C b \times I R b \times E F \times F I \times E D$

Ingestion of contaminated milk from cattle grazed on pasture grasses and fed with the floodplain surface water bodies

Noncarcinogens

Chronic daily intake (mg/kg-day)

Radionuclides

Lifetime intake (pCi/lifetime)
$=$

$\frac{C m \times I R m \times F I \times E F \times E D}{B W \times A T}$

$C m=F m[(C p \times Q p)+(Q s \times C s)+(Q w \times C w)]$

$=\quad \mathrm{Cm} \times \mathrm{IRm} \times \mathrm{EF} \times \mathrm{FI} \times \mathrm{ED}$

Where

$\mathrm{Cb}$ Contaminant concentration in beef (calculated value; chemical-specific; $\mathrm{mg} / \mathrm{kg}$ ).

IRb Ingestion rate for beef $10.075 \mathrm{~kg} /$ day) (EPA, 1989a).

FI Fraction of diet (meat/milk) ingested (0.75, unitless; subsistence farm family).

EF Exposure frequency (350 days/year).

ED Exposure duration 17 years for an adult for noncarcinogens; 70 vears for carcinogens).

BW Body weight $170 \mathrm{~kg}$ for an adult).

AT Averaging time (365 days $x$ ED).

$\mathrm{Fb}$ Forage-to-beef transfer coefficient (chemical-specific; unitless).

Cp Contaminant concentration in pasture grasses (calculated value; chemical-specific: $\mathrm{mg} / \mathrm{kg}$ ).

Qp Quantity of pasture ingested daily by cattle $(19 \mathrm{~kg} \mathrm{DW} /$ day).

Qs Quantity of soil ingested daily by cattle $10.38 \mathrm{~kg}$ based on $2 \%$ of dry matter from feed ingestion rate).

Cs Contaminant concentration in soil (the highest determined concentration in the floodplain specified Incation; $\mathrm{mg} / \mathrm{kg}$ ).

Qw Quantity of water ingested daily by cattle (56 L/day).

Cw Contaminant concentration in surface water bodies (the highest determined concentration at the floodplain specified location; $\mathrm{mg} / \mathrm{L}$ ).

$\mathrm{Cm}$ Contaminant concentration in milk (calculated value; chemical-specific; $\mathrm{mg} / \mathrm{kg}$ ).

IRm Ingestion rate for milk $(0.30 \mathrm{~kg} /$ day) (EPA, 1989a).

Fm Feed-to-milk transfer coefficient (chemical-specific; unitless). 
Table 4.12 Exposure dose calculations for future hypothetical adult meat and milk consumption from cattle grazed in the San Juan River floodplain, Shiprock, New Mexico, site (Concluded)

\begin{tabular}{|c|c|c|c|c|c|c|c|}
\hline \multirow{3}{*}{$\begin{array}{c}\text { Contaminant of } \\
\text { potential } \\
\text { concern }\end{array}$} & \multicolumn{2}{|c|}{$\begin{array}{l}\text { Contaminant } \\
\text { concentration }\end{array}$} & \multirow{2}{*}{\multicolumn{2}{|c|}{$\begin{array}{c}\text { Transfer } \\
\text { coefficients }\end{array}$}} & \multirow{2}{*}{\multicolumn{2}{|c|}{$\begin{array}{c}\text { Exposure dose } \\
\text { (mg/kg-day) }\end{array}$}} & \multirow{3}{*}{$\begin{array}{l}\text { Total intake } \\
\text { (mg/kg-day) }\end{array}$} \\
\hline & \multirow{2}{*}{$\begin{array}{c}\text { Surface } \\
\text { water } \\
\text { Cw } \\
(\mathrm{mg} / \mathrm{L})\end{array}$} & \multirow{2}{*}{$\begin{array}{c}\text { Sediment } \\
\text { Cs } \\
(\mathbf{m g} / \mathbf{k g})\end{array}$} & & & & & \\
\hline & & & $\mathbf{F b}$ & $\mathbf{F m}$ & Beof & Milk & \\
\hline \multicolumn{8}{|l|}{ Noncarcinogens } \\
\hline Selenium & 0.035 & 4.2 & 0.015 & 0.004 & $4 E-04$ & $4 E-4$ & $8 E-04$ \\
\hline Strontium & 7.34 & 1620 & 0.0003 & 0.0015 & $1 \mathrm{E} \cdot 02$ & $2 E-01$ & $2 E-01$ \\
\hline Uranium & 1.1 & 44 & 0.0002 & 0.0006 & $1 E \cdot 05$ & $2 E-04$ & $2 E-4$ \\
\hline \multicolumn{8}{|l|}{ Carcinogens } \\
\hline Uranıum ${ }^{b}$ & $755^{c}$ & $501^{d}$ & 0.0002 & 0.0006 & $8 E+04^{8}$ & $1 E+05^{\theta}$ & $2 E+05^{\theta}$ \\
\hline
\end{tabular}

${ }^{a}$ All values except uranium in surface water are from location 659 . Uranium in surface water is from location 660. Refer to Section 7.0 for a detailed description of surface water and sediment sampling locations.

buranium-234 and uranium-238 combıned; $1 \mathrm{mg}$ uranium is assumed to equal $686 \mathrm{pCi}$.

cPicocuries per liter.

dPicocuries per kilogram.

epicocuries per lifetime. 


\subsection{EXPOSURE ASSESSMENT UNCERTAINTIES}

Potential sources of error may arise in all phases of exposure assessment. The following significant uncertainties could lead to an underestimate or overestimate in the exposure analysis:

- Uncertainties resulting from the lack of thorough environmental sampling data.

- Uncertainties arising from the assumption that the ground water contaminant source term at the site has reached a steady state and that contaminant concentrations at the exposure point will remain constant for chronic periods of exposure (generally at least 7 years).

- Uncertainties associated with the model used to estimate contaminant uptake into plants and pasture grasses present in the floodplain area, as well as contaminant intake by grazing livestock. The plant uptake factors could vary substantially from the default estimates under the site conditions at Shiprock.

- Uncertainties associated with the relationship between an applied dose lused in this assessment) and absorbed dose or effective toxic dose for dermal absorption.

- Uncertainties associated with the different intakes of subpopulations such as diabetics.

Regardless of these uncertainties, the intake estimates derived in this section likely represent reasonable, maximum exposures if ground water or its surface expressions are used at the site. 


\subsection{TOXICITY ASSESSMENT}

Several contaminants that could adversely affect human health and the environment have been detected in ground water at the site. This section summarizes the toxicological effects of the chemical contaminants and the carcinogenic potentials of arsenic and the radionuclides. The following source materials were used in developing these toxicological profiles: when available, EPA's Integrated Risk Information System (IRIS) (EPA, 1993; 1991; 1988a); the Agency for Toxic Substances Disease Registry Toxicological Profiles published by the Department of Health and Human Services (DHHS) (DHHS, 1993a; 1993b; 1989); and the Handbook on the Toxicology of Metals (Friberg et al., 1986a). When these review documents were not available, peer-reviewed scientific literature was cited. By basing toxicity information on the standardized review documents cited above, the evaluation of risks at UMTRA Project sites should be consistent with evaluations at sites regulated under different legislation.

The toxicity profiles presented here focus on drinking water source material in humans when it is available, and include animal information only when human data are not available. Animal information is presented on the toxicity range graphs by the use of widely spaced dotted lines. When uncertainty exists about the beginning or ending points of a range of exposures that produces specific toxic effects, closely spaced dots are used at the appropriate end of the line denoting range.

\subsection{CONTAMINANT TOXICITY SUMMARIES}

The following summaries address the basic toxicokinetics and toxicity of the 11 contaminants of potential concern at Shiprock based on the preliminary screening discussed previously. The contaminants of potential concern are antimony, arsenic, cadmium, magnesium, manganese, nitrate, selenium, sodium, strontium, sulfate, and uranium. Although these contaminants have a wide range of toxic effects depending on the exposure levels, the following discussion focuses on the toxic effects observed in the exposure range most relevant to contamination at the Shiprock site.

\subsubsection{Antimony}

\section{Absorption}

Antimony absorption can occur both through inhalation and ingestion. At least 15 percent of a single oral dose of labeled antimony potassium tartrate given to mice is absorbed (i.e., recovered in urine and tissues). However, absorption may be higher since gastrointestinal excretion starts immediarely after the metal is taken up from the gut (Friberg et al., 1986a).

\section{Tissue accumulation and clearance}

Surface body scanning of people given intravenous injections of labeled antimony as sodium antimony dimercaptosuccinate revealed the highest amounts accumulate in the liver, thyroid, and heart. Forty-three days after the last injection, the liver still 
showed values of about one-sixth of +1, ... after the last injection.

Single intravenous or intramuscular injections to human volunteers produced higher 24-hour urinary excretion of pentavalent ( $8 n$ nercent) than of trivalent ( 25 percent) antimony compounds, a pattern similar to the one found in animals.

A study on the elimination of a single intravenously administered dose of labeled antimony potassium tartrate (trivalent) indicated that urinary excretion is about four times higher than fecal excretion. The initial excretion of antimony in humans is rapid. When pentavalent antimony compounds are given intravenously or intramuscularly, more than 90 percent of the dose will be found in the urine within 24 hours.

\section{Environmental sources of antimony}

Dietary antimony intake ranged from 0.25 to $1.25 \mathrm{mg} /$ day in a study of institutional diets for children in the United States (Friberg et al., 1986a). Assuming an average body weight of $35 \mathrm{~kg}$, this intake is equivalent to 0.007 to $0.04 \mathrm{mg} / \mathrm{kg}$-day.

In freshwater fish, antimony concentrations have been reported to be on the order of 3 micrograms per kilogram $(\mu \mathrm{g} / \mathrm{kg})$ wet weight. Levels of 3 and $8 \mu \mathrm{g} / \mathrm{kg}$ have been found in milk and potato powder. Antimony is sometimes present in the binding coat between enamel and metal, especially in older cooking utensils, and can be dissolved by acidic food and drink when the enamel coating is worn. In soil, antimony usually ranges from 0.1 to $10 \mathrm{mg} / \mathrm{kg}$ dry weight (DW).

\section{Toxicity of antimony}

The EPA oral reference dose (RfD) for antimony is $0.0004 \mathrm{mg} / \mathrm{kg}$-day. The RfD is based on a lifetime study of rats exposed to antimony trioxide in drinking water. The lowest dose producing adverse health effects (increased mortality of animals and alteration of blood chemistry) was $0.42 \mathrm{mg} / \mathrm{kg}$-day.

After drinking lemonade containing 0.013 percent antimony, 70 people developed acute symptoms, including burning stomach pain, colic, nausea, and vomiting. It is estimated that a $70-\mathrm{kg}$ adult consuming 300 milliliters $(\mathrm{mL})$ of lemonade would have received a dose of approximately $0.5 \mathrm{mg} / \mathrm{kg}$.

One study indicated that female workers exposed in an antimony plant experienced a greater incidence of spontaneous abortions than did a control group of nonexposed working women. A high rate of premature deliveries among women who worked in antimony smelting and processing was also observed.

Reconstruction of dose and exposure conditions in the occupational setting is not available. The health effects from exposure to antimony as a function of dose are summarized in Figure 5.1. 


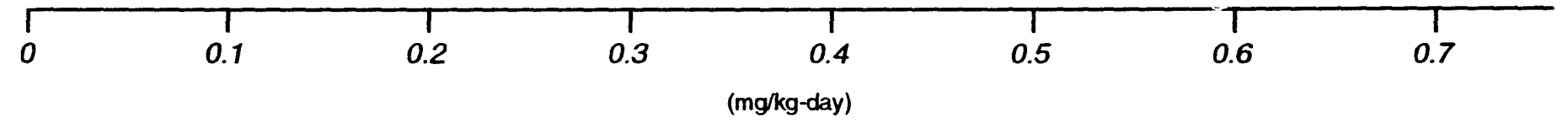

A Oral RefERENCE dOSE (0.0004 mg/kg-day)

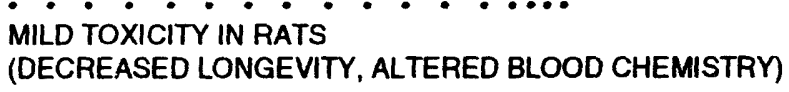

(DECREASED LONGEVITY, ALTERED BLOOD CHEMISTRY)

MILD TOXICITY IN HUMANS

(GASTROINTESTINAL DISTRESS AFTER ACUTE EXPOSURE)

FIGURE 5.1

ANTIMONY TOXICITY RANGES 


\subsubsection{Arsenic}

\section{Absorption}

Arsenic is effectively absorbed through the gastrointestinal tract and through inhalation. Dermal absorption is negligible. In humans, approximately 80 percent of an ingested amount of dissolved inorganic trivalent (arsenite) or pentavalent arsenic (arsenate) is absorbed from the gastrointestinal tract (Pershagen and Vahter, 1979; Marafante and Vahter, 1987).

\section{Tissue accumulation and clearance}

After absorption by the gastrointestinal tract, arsenic is transported via the blood to most tissues. In humans as well as in most animal species, exposure to either arsenite or arsenate leads to an initial accumulation in the liver, kidneys, and lungs. Clearance from these tissues is very rapid, and long-term retention of arsenic is seen in organs rich in sulfhydryl-containing proteins such as the hair, skin, squamous epithelium of the upper gastrointestinal tract, epididymis, thyroid, lens, and skeleton (Lindgren et al., 1982). Specific target tissue is dependent on the form of arsenic. Higher arsenic retention occurs after exposure to trivalent arsenic than to the pentavalent form and tissue distribution is altered.

In humans and rats, inorganic arsenic passes through the placental barrier. It has also been demonstrated to enter both cow and human milk (Marcus and Rispin, 1988).

In the human body, where methylcobalamine acts as a major methyl group donor in the biotransformation process, inorganic arsenic is converted to methylated compounds. It has been demonstrated that the major site of arsenic methylation is the liver (Marcus and Rispin, 1988). Trivalent arsenic is the substrate for methylation and pentavalent arsenic must be reduced to trivalent arsenic before methylation can occur. Dimethylarsenic acid is a major metabolite found in animals and humans. Methylation results in a detoxification of inorganic arsenic labout 1 order of magnitude per methyl group) and increases the rate of arsenic excretion from the body.

The major route of excretion following human exposure to inorganic arsenic is via the kidneys (Ishinishi et al., 1986). Only a small amount is excreted in feces. The rate of excretion in urine varies, depending on the chemical form of arsenic and the species exposed. In humans exposed to a single low dose of arsenite, about 35 percent is excreted in urine over a 48-hour period (Buchet et al., 1980; 1981). In the case of continuous human intake over a few days, 60 to 70 percent of the daily dose is excreted in urine (Buchet et al., 1981). The limited human data available indicate the excretion rate after exposure to arsenite is similar to that of arsenate. Other, less important routes of elimination of inorganic arsenic include skin, hair, nails, and sweat. 
After oral intake of radiolabeled pentavalent arsenic, 66 percent is excreted with a half-time of 2.1 days, 30 percent with a half-time of 9.5 days, and 3.7 percent with a half-time of 38 days (Marcus and Rispin, 1988).

\section{Environmental sources of arsenic}

Arsenic is ubiquitous in nature in both inorganic and organic compounds. Water is the major means of arsenic transport under natural conditions. In oxygenated water, arsenic occurs in a pentavalent form; under reducing conditions (e.g., in artesian well waters), the trivalent form predominates. Sedimentation of arsenic in association with iron and aluminum represents a considerable factor in environmental transport and deposition of this element (Marcus and Rispin, 1988).

As a result of arsenic's widespread occurrence, the general human population is exposed to it primarily from drinking water and foodstuffs. Certain target groups are exposed to arsenic from industrial and agricultural uses. Medicinal use is also a significant means of human exposure.

Drinking water usually contains a few micrograms of arsenic, predominantly as inorganic salts in the trivalent and pentavalent states (WHO, 1981). However, concentrations of up to $1.1 \mathrm{mg} / \mathrm{L}$ in drinking water are reported in Chile, Argentina, Taiwan, the United States, and the United Kingdom (WHO, 1981).

Certain foodstuffs contain appreciable amounts of arsenic. Arsenic concentrations in fish and seafood, particularly shellfish, are generally 1 or 2 orders of magnitude higher than in other foods. Wine and mineral waters can contain several hundred micrograms of arsenic per liter (Crecelius, 1977; WHO, 1981).

\section{Toxicity of arsenic}

Exposure levels associated with acute arsenic toxicity vary with the valency form of the element. Trivalent arsenicals (arsenites) are generally more toxic than pentavalent (arsenates) (Morrison et al., 1989); inorganic arsenic compounds are more toxic than organic (Shannon and Strayer, 1989). Based on geochemical models for the Shiprock site, arsenic exists primarily in the pentavalent form in ground water (Table 3.5). For arsenic trioxide, the reported estimated acute oral lethal dose in humans ranges from 70 to $300 \mathrm{mg}(1$ to $4 \mathrm{mg} / \mathrm{kg}$-day) (EPA, 1984). Acute exposure to inorganic arsenic compounds may lead to a severe inflammation of the gastrointestinal tract, encephalopathy, and acute renal failure after ingestion.

Teratogenic effects of arsenic compounds administered intravenously or intraperitoneally at high doses have been demonstrated in laboratory animals only (Ferm, 1971; Hood, 1972; 1983; EPA, 1984).

Chronic arsenic intoxication results from exposure to small doses of arsenic over a long period of time. These intoxications frequently are caused by arsenic that occurs naturally in drinking water and in food. Changes of the skin leading to skin cancer are commonly seen in populations exposed to high concentrations of arsenic 
in drinking water. Endemic arsenic poisoning is seen in Cordoba, Argentina, where the concentration of arsenic in drinking water ranges from 0.9 to $3.4 \mathrm{mg} / \mathrm{L}$ (equivalent to 0.026 to $0.097 \mathrm{mg} / \mathrm{kg}$-day). Certain areas in Taiwan also have high natural arsenic concentrations in drinking water that cause blackfoot disease la peripheral extremity vascular disorder resulting in gangrene). A dose-response relationship between the incidence of blackfoot disease and the duration of exposure to arsenic is documented (Tseng, 1977).

Hyperpigmentation, hyperkeratoses, and skin cancer with prevalence of 7.1 percent, 18.4 percent, and 1.1 percent, respectively, were reported in Taiwanese studies of more than 40,000 people exposed to arsenıc in drinking water at daily intakes ranging from 1.4 to $6.3 \mathrm{mg}$.

Increasing chronic oral ingestion doses of arsenic progressively produces systemic effects, including arterial thickening in children and adults $(0.02 \mathrm{mg} / \mathrm{kg}$-day); neurological symptoms, including peripheral neuropathy $(0.04 \mathrm{mg} / \mathrm{kg}$-dayl; fibrosis of the liver $(0.05 \mathrm{mg} / \mathrm{kg}$-day); and cirrhosis of the liver $10.08 \mathrm{mg} / \mathrm{kg}$-day) (DHHS, 1993a).

Certain characteristics of exposed human populations may influence arsenic toxicity at high exposure levels. Genetic disposition (rapid versus poor acetylators) and a protein-deficient diet may decrease arsenic methylation. This can result in an increased deposition of the element in the target organs (e.g., lung or skin).

The EPA has classified inorganic arsenic as a Group A (human) carcinogen (EPA, 1988a), based on the occurrence of increased lung cancer mortality in populations exposed primarily through inhalation and of increased skin cancer prevalence in populations exposed through consumption of drinking water containing high arsenic concentrations. The current cancer slope factor for oral exposure to arsenic is given in Table 5.1. This slope factor is currently under EPA review for recent data suggesting arsenic ingestion may result in increased cancers in internal organs and skin cancers. The health effects of exposure to arsenic as a function of dose are summarized in Figure 5.2.

\subsubsection{Cadmium}

\section{Absorption}

In humans, approximately 5 percent of ingested cadmium in water is absorbed, but this figure can increase substantially following exposure to other metals (such as calcium or iron) or with increased protein intake (Friberg et al., 1986b). The amount of cadmium absorbed from food sources is about half the amount absorbed from water. Absorption also substantially increases in individuals with low iron stores (Flanagan et al., 1978). Once absorbed, cadmium is bound to protein, primarily metallothionein. The ability of many metals to increase the concentration of metallothionein is likely the basis for interactions in absorption, tissue concentrations, and toxicity of combined exposures to metals. 
Table 5.1 Toxicity values: carcinogenic effects

\begin{tabular}{|c|c|c|c|c|}
\hline Parameter & $\begin{array}{c}\text { Oral slope factor } \\
(\mathrm{pC} i)^{-1},(\mathrm{mg} / \mathrm{kg} \text {-day })^{-1} \\
\end{array}$ & $\begin{array}{c}\text { Weight of } \\
\text { evidence } \\
\text { classification }\end{array}$ & Type of cancer & $\begin{array}{c}\text { Slope factor } \\
\text { basis and } \\
\text { source } \\
\end{array}$ \\
\hline $\begin{array}{l}\text { Arsenic } \\
\text { inorganic }\end{array}$ & $1.8 E+0$ & A & Skin & Water/HEAST \\
\hline Lead-210 & $5.1 E-10$ & A & Bone & Water/HEAST \\
\hline Polonium-210 & $1.5 \mathrm{E}-10$ & A & $\begin{array}{l}\text { Liver, kidney, } \\
\text { spleen }\end{array}$ & Water/HEAST \\
\hline Radium-226 & $1.2 E-10$ & A & Bone & Water/HEAST \\
\hline Thorium-230 & $1.3 E-11$ & A & Bone & Water/HEAST \\
\hline Uranium-238 & $1.6 \mathrm{E}-11$ & $A$ & Note ${ }^{a}$ & Water/HEAST \\
\hline Uranium-234 & $1.6 \mathrm{E}-11$ & A & Note ${ }^{a}$ & Water/HEAST \\
\hline
\end{tabular}

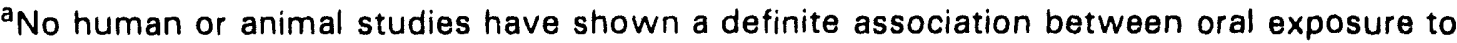
uranium and development of cancer.

\section{Tissue accumulation and clearance}

Humans with low-level exposure to cadmium show approximately 50 percent of the body burden in the kidneys, 15 percent in the liver, and 20 percent in muscle (Kjellström and Nordberg, 1978). The kidney concentration will increase with continued exposure only to about age 50 , but the concentration in muscle will increase throughout life. In cases of high exposure resulting in kidney damage, kidney concentrations can be quite low, but liver concentrations can be up to 100 times higher than normal. Only 0.01 to 0.02 percent of the total body burden of cadmium is excreted daily, resulting in continuously increasing body burdens with continuous exposure. The biological half-time of cadmium, or the time necessary to eliminate 50 percent of the cadmium in the body at a given time, is 10 to 30 years in humans (Nordberg et al., 1985).

\section{Environmental sources of cadmium}

Normal cadmium content of food and water in nonpolluted areas results in 0.01 to $0.06 \mathrm{mg} /$ day intake of cadmium $(0.0001$ to $0.0009 \mathrm{mg} / \mathrm{kg}$-day). Cadmium occurs naturally with zinc and lead; it is therefore often present as an impurity in products using these metals, such as solders and galvanized metals. These sources lead to contact with water supplies in water heaters and coolers, some pipes, and taps. Cadmium is also a component of rechargeable nickel-cadmium batteries. Improper disposal of these batteries can also be a source of environmental contamination. 


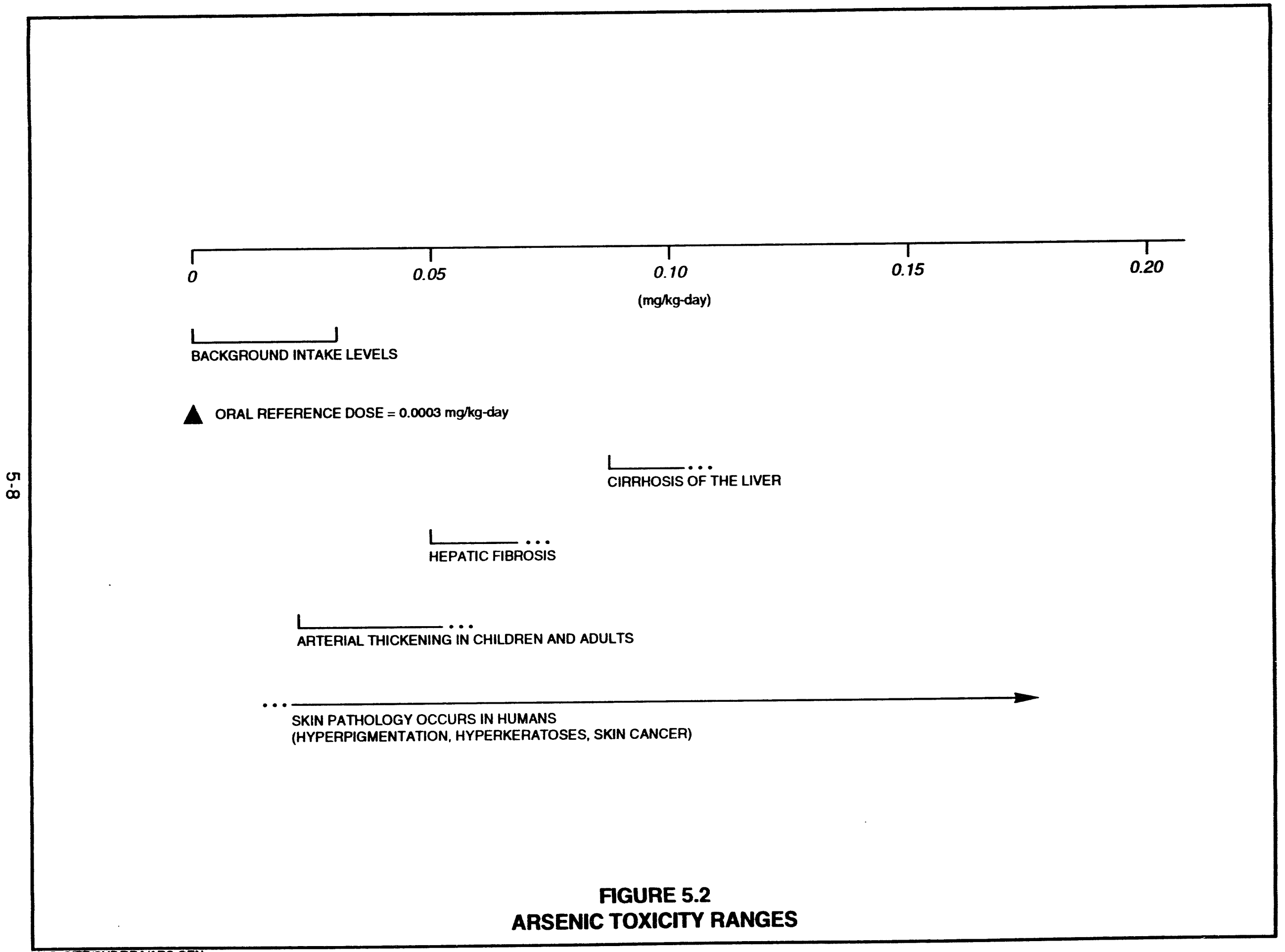


Cadmium is also present as a contaminant in cigarette smoke. Smoking one cigarette can result in inhalation of 0.001 to $0.002 \mathrm{mg}$ of cadmium. Total body burden of cadmium can increase by $15 \mathrm{mg}$ after 20 years of smoking.

\title{
Toxicity of cadmium
}

Acute exposure to high concentrations of cadmium (15 mg/L in water) results in acute gastrointestinal effects, including abdominal cramps, diarrhea, and vomiting $10.07 \mathrm{mg} / \mathrm{kg})$. These gastrointestinal effects have not been reported in any chronic environmental exposure.

The primary toxic effect of long-term exposure to cadmium is reabsorption disturbance in the proximal tubules of the kidney. This effect is first observed by an increase of low molecular-weight proteins in the urine. This initial effect is observed following a daily intake of $0.0075 \mathrm{mg} / \mathrm{kg}$-day. Progressive disruption of kidney function will lead to an increase in amino acids, glucose, phosphate, and protein in urine. Long-term exposure can also disturb calcium metabolism, leading to osteoporosis and osteomalacia. A combination of these two effects is referred to as Itai-itai disease and was seen in epidemic proportions in a cadmiumcontaminated region in Japan in the 1950s (Friberg et al., 1986b). Chronic dietary exposures of humans to cadmium produce no observable adverse health effects at exposure levels from 0.001 to $0.002 \mathrm{mg} / \mathrm{kg}$-day (DHHS, 1993b). These health effects are summarized in Figure 5.3 as a function of dose. Because of already compromised kidney function, diabetics and the elderly can be more susceptible to cadmium toxicity (Buchet et al., 1990).

Cadmium is classified as a probable human carcinogen by EPA (EPA, 1993) and IARC (IARC, 1987). Although chronic inhalation of cadmium oxide has been related to increased lung and prostate cancers in workers. Because of the presence of other known carcinogens in the workplace and small statistical differences in tumor incidences, evidence linking cadmium to cancer in humans is inconclusive at this time (DHHS, 1993b). No data, however, link oral cadmium ingestion to cancer in humans or animals (DHHS, 1993b).

\subsubsection{Magnesium}

\begin{abstract}
Absorption
Ingested magnesium is absorbed mainly in the small intestine. Absorption of dietary magnesium has been determined to be 30 to 40 percent. Calcium and magnesium are competitive with respect to their absorptive sites, and excess calcium may partially inhibit magnesium absorption (Aikawa, 1963).
\end{abstract}

\section{Tissue accumulation and clearance}

Most magnesium present in the body is in the bones. Bone magnesium seems to be a reservoir to ensure that some will be on hand for vital reactions, regardless of dietary intake. Magnesium, a principal intracellular cation of soft tissue, is mainly 


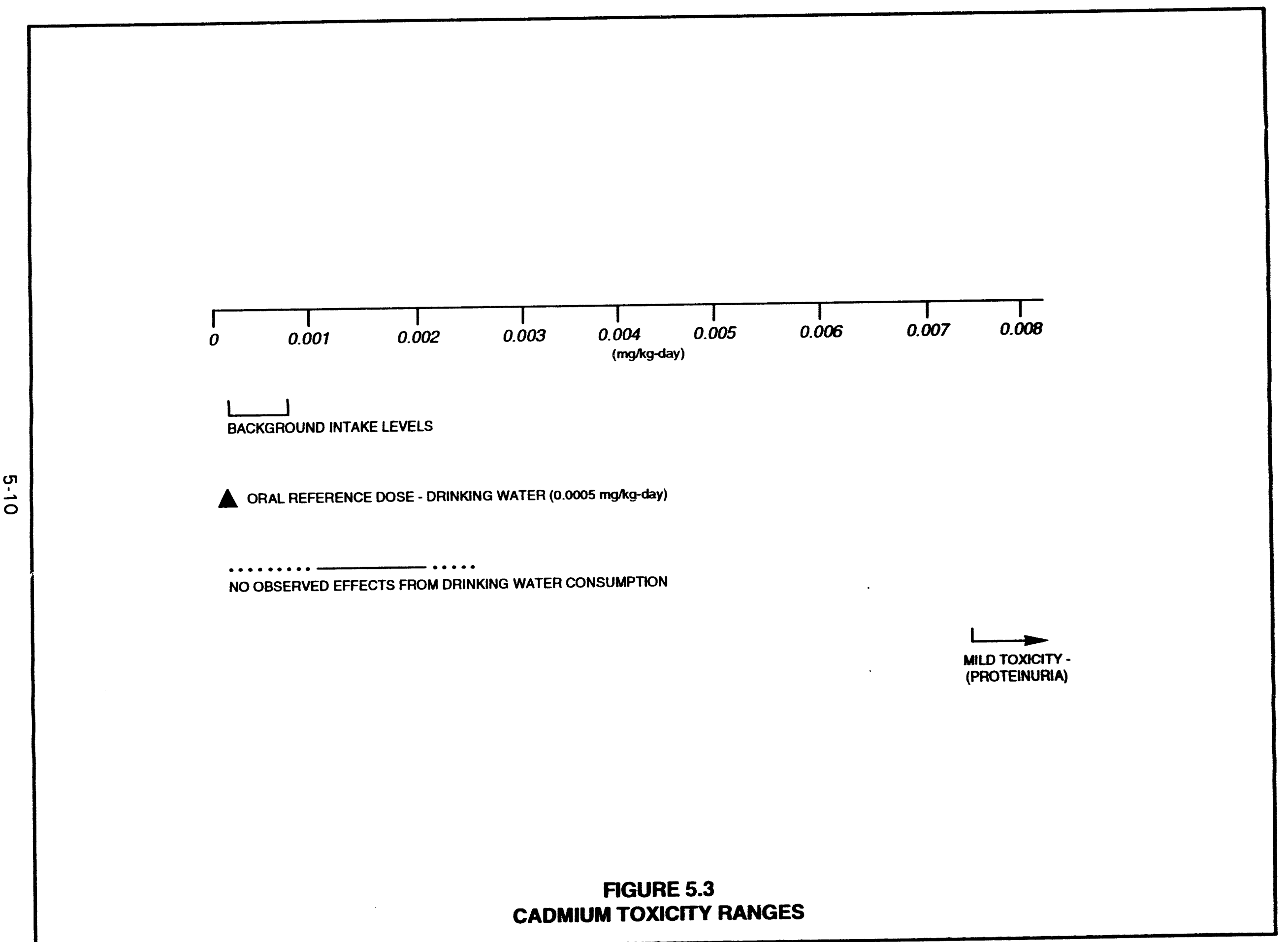


involved as a cofactor in enzymatic reactions associated with the metabolism of carbohydrates and proteins. It is also involved in neurochemical transmission and neuromuscular excitability (AHFS, 1991).

The major excretory pathway for absorbed magnesium is the kidney. In subjects on a normal diet, one-third or less of the ingested magnesium is excreted by the kidney. Approximately two-thirds of ingested magnesium is excreted in the feces.

\section{Environmental sources of magnesium}

Magnesium is readily available in ingested food, particularly from nuts, cereals, seafood, and meats. The average city water contains about 6.5 parts per million of magnesium, but amounts vary considerably, increasing with the hardness of the water.

The recommended daily allowance (RDA) for magnesium ranges from 4.5 to $6.7 \mathrm{mg} / \mathrm{kg}$-day. In the United States, the average adult ingests between 240 and $480 \mathrm{mg}$ of magnesium daily (from 3.4 to $6.9 \mathrm{mg} / \mathrm{kg}$-day).

\section{Toxicity of magnesium}

Available human data on chronic magnesium toxicity following ingestion is limited. It has been reported that therapeutic doses of ingested magnesium as low as $6.9 \mathrm{mg} / \mathrm{kg}$-day may have a laxative effect (AHFS, 1991 ).

In patients with severe renal impairment, hypermagnesemia (characterized by hypotension, nausea, vomiting, electrocardiogram changes, respiratory or mental depression, and coma) has occurred after administration of antacids containing magnesium (AHFS, 1991). However, the threshold dose level for these side effects has not been reported. The health effects from exposure to magnesium as a function of dose are summarized in Figure 5.4.

\subsubsection{Manganese}
Absorption
Following ingestion, manganese absorption is homeostatically controlled: the absorption rate depends on both the amount ingested and tissue levels of manganese. Adults absorb approximately 3 to 4 percent of dietary manganese (Saric, 1986). Manganese can be absorbed following exposure by inhalation, ingestion, and dermal contact. In humans, available data indicate that only 3 percent of an ingested dose of manganese chloride is absorbed (Mena et al., 1969). The absorption rate is influenced by iron and other metals. In states of iron deficiency, manganese is actively absorbed from the intestine. Individuals with anemia can absorb more than twice the percentage of an ingested dose. However, in states of excess iron, manganese absorption is by diffusion only (Saric, 1986). High levels of dietary calcium and phosphorus are shown to increase the refulirements for manganese in several species (Lönnerdal et al., 1987). 


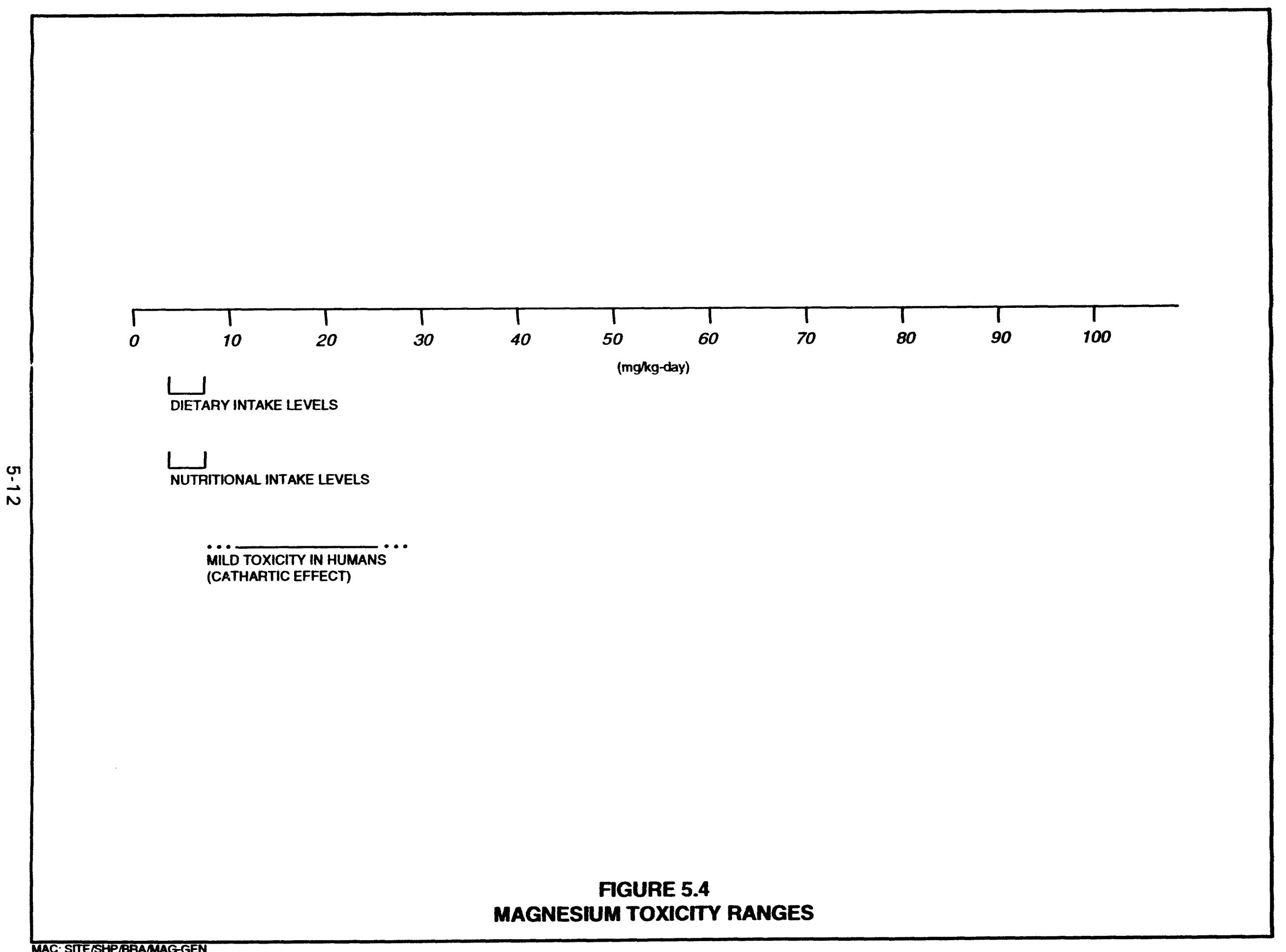




\section{Tissue accumulation and clearance}

Manganese is widely distributed throughout the body. The highest concentrations are found in the liver and kidney and, to a lesser extent, the hair. The biological half-time in humans is 2 to 5 weeks, depending on body stores. Manganese readily crosses the blood-brain barrier and is more slowly cleared from brain than from other tissues (Goyer, 1991). Normal concentrations in the brain are low, but the half-time in the brain is longer and the metal may accumulate in the brain with excessive absorption (NRC, 1973).

Absorbed manganese is rapidly eliminated from the blood and concentrates in mitochondria. Initial concentrations are greatest in the liver. Manganese penetrates the placental barrier in all species and is more uniformly distributed throughout the fetus than in adult tissues. It is secreted into milk.

Absorbed manganese is almost totally secreted in bile and reabsorbed from the intestine as necessary to maintain body levels. At excessive exposure levels, other gastrointestinal routes may participate. Excess manganese is eliminated in the feces; urinary excretion is negligible (Goyer, 1991; Saric, 1986).

\section{Environmental sources of manganese}

On the whole, food constitutes the major source of manganese intake for huinans. The highest manganese concentrations are found in plants, especially wheat and rice. Drinking water generally contains less than $0.1 \mathrm{mg} / \mathrm{L}$. Manganese levels in soil range from 1 to $7000 \mathrm{mg} / \mathrm{kg}$, with an average of 600 to $900 \mathrm{mg} / \mathrm{kg}$. Mining and natural geological background variation can contribute to this variability. Manganese bioaccumulates in marine mollusks up to 12,000 fold, and there is evidence for toxic effects in plants (phytotoxicity) and plant bioaccumulation. The Illinois Institute for Environmental Quality has recommended a criterion of 1 to 2 $\mathrm{mg} / \mathrm{kg}$ for manganese in soil and $200 \mathrm{mg} / \mathrm{kg}$ in plants (Saric, 1986).

Variations in manganese intake can be explained to a large extent by differences in nutritional habits. In populations with cereals and rice as main food sources, the intake will be higher than in areas where meat and dairy products are a larger part of the diet. The average daily intake has been estimated to be between 2.0 to $8.8 \mathrm{mg} /$ day $(0.03$ to $0.13 \mathrm{mg} / \mathrm{kg}$-day) (EPA, 1993), but intakes as high as $12.4 \mathrm{mg}$ (about $0.2 \mathrm{mg} / \mathrm{kg}$-day) are reported in countries with high cereal intake (Saric, 1986).

Drinking water generally results in an intake of less than $0.2 \mathrm{mg}(0.003 \mathrm{mg} / \mathrm{kg}$-day), although some mineral waters can increase this amount by more than threefold (Saric, 1986). One study from Greece reported drinking water concentrations of manganese in excess of $2 \mathrm{mg} / \mathrm{L}$, which would result in daily intakes in the range of 0.06 to $0.07 \mathrm{mg} / \mathrm{kg}$-day (EPA, 1993). 


\section{Toxicity of manganese}

Manganese is an essential nutrient. Estimated safe and adequate daily dietary intakes for adults range from 0.03 to $0.07 \mathrm{mg} / \mathrm{kg}$-day (Saric, 1986). The EPA noobserved-adverse-effect level (NOAEL) for drinking water is set at $0.005 \mathrm{mg} / \mathrm{kg}$-day while the lowest-observed-adverse-effect level (LOAEL) for drinking water is 0.06 $\mathrm{mg} / \mathrm{kg}$-day. The EPA RfD for drinking water is $0.005 \mathrm{mg} / \mathrm{kg}$-day. The RfD for food ingestion is $0.14 \mathrm{mg} / \mathrm{kg}$-day. There is some indication that manganese in drinking water is potentially more bioavailable (i.e., more readily absorbed) than manganese in dietary food sources. This would result in toxic effects with lower ingested doses of manganese in drinking water than in food (EPA, 1993).

Inhalation of manganese in industrial settings has provided the largest source of data on chronic manganese toxicity. These data indicate that excess manganese can result in a central nervous system disorder consisting of irritability, difficulty in walking, speech disturbances, and compulsive behavior that may include running, fighting, and singing. With continued exposure, this condition can progress to a mask-like face, retropulsion or propulsion, and a Parkinson-like syndrome. The condition reverses slowly with removal of manganese exposure. Metal chelating agents are ineffective in treatment, but L-dopa has been effective in treatment (Goyer, 1991 ).

Information is limited on the effects of manganese ingestion. Because effects from drinking water seem to differ from those from food sources, only studies on water consumption will be considered here. A Japanese study of 25 people drinking well water with manganese concentrations of $14 \mathrm{mg} / \mathrm{L}(0.4 \mathrm{mg} / \mathrm{kg}$-day estimated intake) reported symptoms of intoxication, including a mask-like face, muscle rigidity and tremors, and mental disturbances. In two cases ( 8 percent), deaths occurred among the intoxicated people. A Greek study of more than 4000 individuals drinking water with manganese concentrations varying from 0.081 to $2.3 \mathrm{mg} / \mathrm{L}$ lestimated intake at $2 \mathrm{~L} /$ day for a $70-\mathrm{kg}$ individual range from 0.002 to 0.07 $\mathrm{mg} / \mathrm{kg}$-dayl showed varying degrees of neurological effects in individuais drinkıng from 0.007 to $0.07 \mathrm{mg} / \mathrm{kg}$-day, but no effects in individuals drinking less than $0.005 \mathrm{mg} / \mathrm{kg}$-day (Kondakis et al., 1989).

The chemical form of manganese has complex effects on its toxicity. Although more soluble forms are more readily absorbed from the gastrointestinal tract, they also appear to be more rapidly cleared. Exposure to insoluble forms results in lower manganese absorption but higher chronic tissue levels and therefore greater toxicity (EPA, 1993). Information is limited on the effects of various forms of manganese.

Few data are available on manganese toxicity in infants, but infants are probably more susceptible to toxicity due to greater absorption and greater penetration into the central nervous system (EPA, 1993; Saric, 1986).

The toxicity of manganese is summarized in Figure 5.5 . 


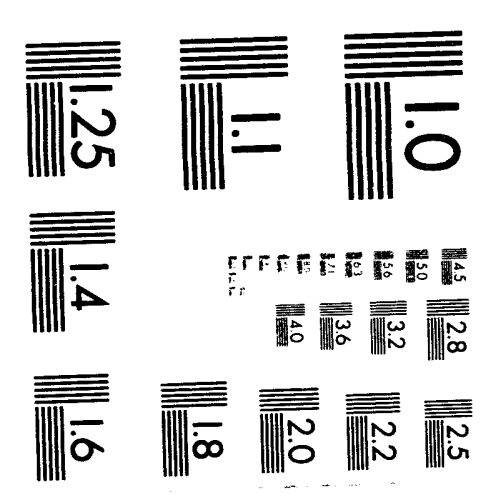



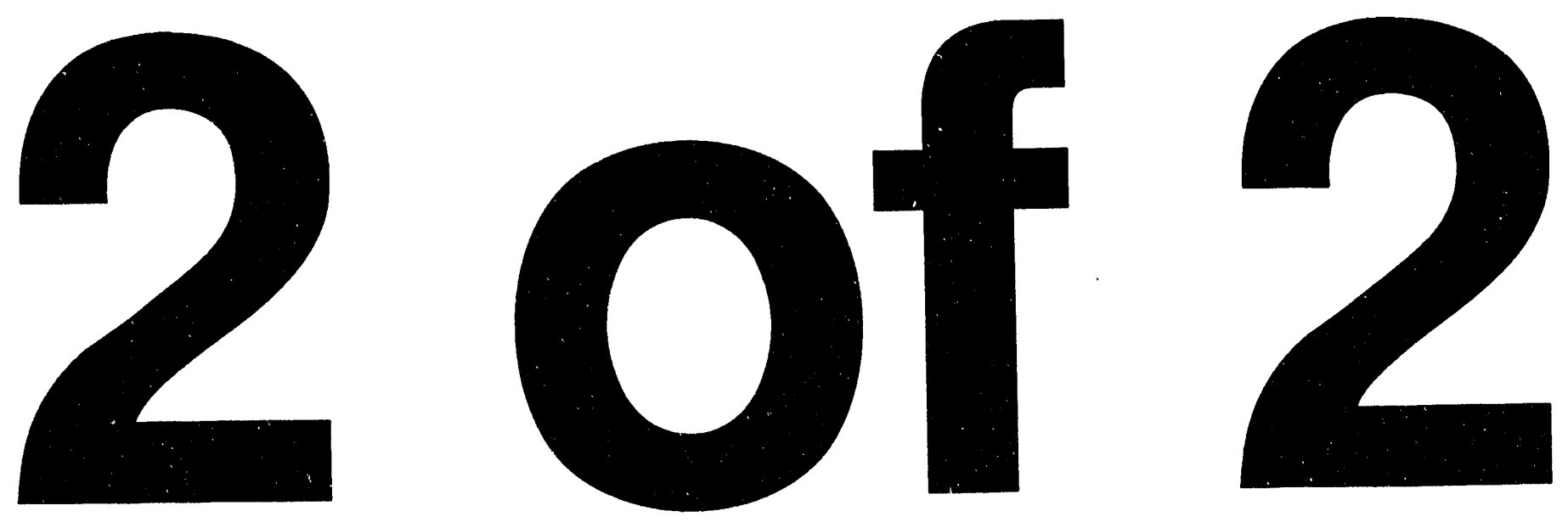


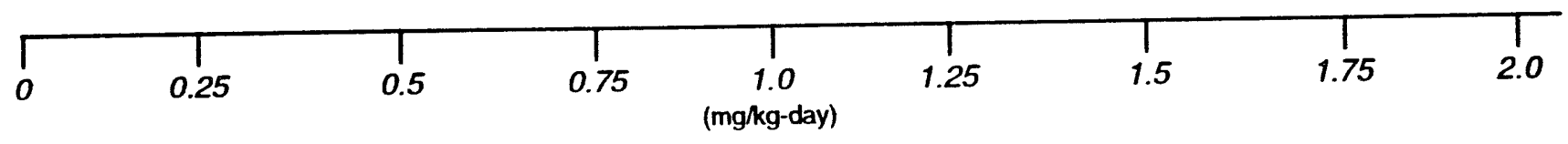

$\triangle$ BACKGROUND DRINKING WATER INTAKE $(0.003 \mathrm{mg} / \mathrm{kg}$-day)

\section{$\bigsqcup$}

DIETARY INTAKE FROM FOOD

$\triangle$ EPA RFD - DRINKING WATER (0.005 mg/kg-day)

EARLY NEUROLOGICAL SYMPTOMS

PARKINSON-LIKE EFFECTS

ACUTE LETHAL DOSE, RODENTS (400- $800 \mathrm{mg} / \mathrm{kg}$-day) 


\subsubsection{Nitrate}

\section{Absorption}

Ingested nitrate is converted in the gut to the toxic nitrite ion, which is readily absorbed. The conversion rate depends on both gut flora and $\mathrm{pH}$, with a more rapid conversion in a higher $\mathrm{pH}$ environment. Infants have a higher gut $\mathrm{pH}$, which is more conducive to bacteria growth. Therefore, the combination of an alkaline environment and increased bacterial conversion increases the production of nitrite from nitrate in infants, resulting in higher blood nitrite levels for a given dose of nitrate. In healthy adults, nitrates are rapidly absorbed from the upper intestine. This rapid absorption reduces the contact time with gut flora, thereby reducing the conversion to nitrite and the resultant toxicity.

\section{Tissue accumulation and clearance}

After absorption, the nitrite ion binds to hemoglobin in the blood and oxidizes it, thereby reducing the oxygen-car, ying capacity of the blood and decreasing the rate of oxygen release. The oxidized hemoglobin is called $\mathrm{m}^{\text {-themoglobin }}$ and can be reduced back to normal hemoglobin enzymatically by methemoglobin reductase. Infants are more sensitive to these effects because of 1 ) the presence of fetal hemoglobin, which is more sensitive to oxidation by nitrite, and 2) lower activity of methemoglobin reductase, meaning the methemoglobin remains oxidized for a longer period. Certain individuals have a rare genetic deficiency in methemoglobin reductase and therefore exhibit higher levels of circulating methemoglobin. Although these individuals develop alternate metabolic pathways to maintain adequate levels of circulating hemoglobin in the normal state, exposure to high levels of nitrate can result in excessive levels of methemoglobin in these individuals.

In healthy adults, the half-time for methemoglobin reductase cunversion of methemoglobin back to hemoglobin is estimated to range from 6 to 24 hours for theoretical methemoglobin levels in the 80 to 100 percent range (Bolyai et al., 1972).

\section{Environmental sources of nitrate}

Nitrates accumulate in soils from the application of fertilizers, human and animal waste, bacterial nitrogen fixation, mineral dissolution, and plant and animal tissue breakdown. These nitrates can filter through the soil into ground water. Concentrations of nitrate in well water reportedly can exceed $440 \mathrm{mg} / \mathrm{L}$, or 10 times the current regulatory levels (Lee, 1970).

Bioaccumulation of nitrates from soil and water to plants results in a wide range of nitrate concentrations in fresh fruits and vegetables, with levels as high as $2000 \mathrm{mg} / \mathrm{kg}$ reported in beets and $9000 \mathrm{mg} / \mathrm{kg}$ in radishes (Kamm et al., 1965; Smith, 1966). The accumulation of nitrates in plant material is increased by factors such as drought, high temperatures, cloudiness, and insect and herbicide damage to 
plants. Nitrates and nitrites are also used to preserve meats, especially corned or smoked products.

\section{Toxicity of nitrate}

The primary toxicity of nitrate is methemoglobinemia, which is a function of the balance between circulating levels of nitrite and methemoglobin reductase activity. A very high acute dose can produce the same toxicity as a lower dose that slowly increases the concentration of methemoglobin over time. Therefore, the acute and chronic toxicities of nitrate are summarized together. To allow easier comparisons between ingested doses of nitrate and ground water levels at Shiprock, dose ranges are presented in terms of nitrate intake. The reader should be aware that nitrate exposure levels are frequently converted to the nitrogen concentration in the nitrate by dividing the nitrate number by 4.4 . Therefore, $44 \mathrm{mg} / \mathrm{L}$ nitrate is equivalent to $10 \mathrm{mg} / \mathrm{L}$ nitrate-nitrogen.

Symptoms of methemoglobinemia can be correlated with the percentage of methemoglobin in the blood as follows: with less than 10 percent methernoglobin, individuals are asymptomatic; more than 25 percent methemoglobin produces weakness, rapid pulse, and tachypnea (rapid breathing); more than 50 to 60 percent methemoglobin can be fatal (EPA, 1993). These symptoms reflect a progressive decrease in available oxygen. As explained above, infants are more sensitive to the production of methemoglobin and therefore are considered the most sensitive population. The route of exposure for infants is formula prepared with contaminated water.

No symptoms of toxicity have been reported with nitrate intakes below $7 \mathrm{mg} / \mathrm{kg}$-day in infants. Mild symptoms such as weakness, rapid pulse, and rapid breathing occur with intakes from 7 to $30 \mathrm{mg} / \mathrm{kg}$-day. The severity of these symptoms increases as increased nitrate intake results in greater levels of methemoglobın and therefore a reduced availability of oxygen. Cyanosis (blue appearance to the skin) occurs, followed by unconsciousness as the availability of oxygen is further reduced. The lowest reported fatal dose of chronic nitrate is $35 \mathrm{mg} / \mathrm{kg}$-day for an infant and $116 \mathrm{mg} / \mathrm{kg}$ (acute intake) for an adult. A wide range of nitrate intake can produce similar symptoms among individuals because of net differences in gut $\mathrm{pH}$, bacterial activity, and methemoglobin reductase activity. These health effects in infants are summarized in Figure 5.6 as a function of dose.

Data on nitrate toxicity are based primarily on epidemiologic studies of human adults and infants who report to hospitals with symptoms of methemoglobinemia. In most cases, exposure doses were back-calculated from sampling their drinking water. Therefore, these data do not represent well-controlled studies with readily defined dosage ranges. Many water sources in these clinical studies showed contamination with bacteria, leading to the possibility that bacterial exposure is a necessary cofactor in the development of methemoglobinemia. Gastrointestinal distress has also been suggested as a cofactor in the development of methemoglobinemia. Infants with colic are more susceptible to nitrate-induced methemoglobinemia. One study indicates that healthy infants could drink nitrate at 


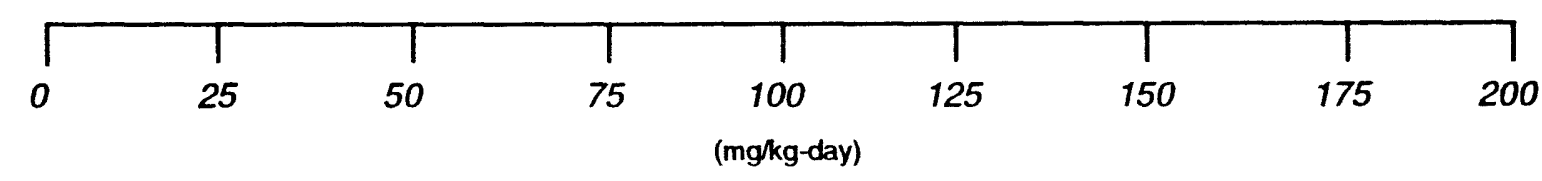

$\triangle$ ORAL REFERENCE DOSE (7 mg/kg-day nitrate)

$\sqcup$

NO OBSERVED EFFECTS

L

MILD TOXICITY - WEAKNESS, RAPID PULSE, RAPID BREATHING

SEVERE TOXICITY-METHEMOGLOBINEMIA INCREASE, CYANOSIS, COMA

POTENTIALLY LETHAL METHEMOGLOBINEMIA

FIGURE 5.6

NITRATE TOXICITY RANGES FOR INFANTS 
$24 \mathrm{mg} / \mathrm{kg}$-day in solutions free of bacteria and show no symptoms of methemoglobinemia (EPA, 1993).

\subsubsection{Selenium}

\section{Absorption}

Although water-soluble forms of selenium such as selenite are approximately 90 percent absorbed in the gastrointestinal tract in rats, humans show lower percentages of absorption (40 to 80 percent) (Bopp et al., 1982). Absorption by ruminants is only 30 to 35 percent, probably because of bacterial reduction in the rumen. Absorption of the less soluble elemental selenium or selenium sulfide is poor in rats (Medinsky et al., 1981; Cummins and Kimura, 1971).

\section{Tissue accumulation and clearance}

Studies suggest similar selenium distributions between humans and laboratory animals (Bopp et al., 1982). At low intake levels, selenium is retained and accumulates in the reproductive organs, brain, and thymus, with only transient accumulation in other organs. Selenite-derived selenium accumulates in the liver and kidneys more rapidly than selenium derived from selenate (Friberg et al., $1986 \mathrm{a})$. There is some indication that organically bound forms of selenium exist in a separate, more bioavailable pool than either selenite and selenate.

Although urinary excretion is the primary route of elimination under normal dietary conditions (67 percent), in deficiency states fecal excretion is the major pathway. At toxic doses, the major route of excretion is through expired air as dimethylselenide (50 to 60 percent) (Friberg et al., 1986a). Although these data were obtained from rats, available data suggest human excretion is similar (Bopp et al., 1982). The elimination of selenium in humans follows three phases with the following half-times: 1,8 to 20 , and 65 to 116 days.

\section{Environmental sources of selenium}

The main source of selenium for the general population is food such as seafood, meat, and grains. Dietary intake of selenium in the United States ranges from 0.0007 to $0.0029 \mathrm{mg} / \mathrm{kg}$-day. Selenium concentrations in ground water and surface water range from 0.00006 to $0.400 \mathrm{mg} / \mathrm{L}$, with highs of $6 \mathrm{mg} / \mathrm{L}$ reported (Friberg et al., 1986a). Concentrations in public water supplies rarely exceed $0.010 \mathrm{mg} / \mathrm{L}$ (EPA, 1980). High selenium concentrations occur in volcanic rock $(0.120$ milligrams per gram $[\mathrm{mg} / \mathrm{g}])$ and in sandstone uranium deposits $(1.0 \mathrm{mg} / \mathrm{g})$. The soil content of selenium varies widely, as does the rate of accumulation by plants. Although grasses and grains do not accumulate selenium in concentrations greater than $50 \mathrm{mg} / \mathrm{kg}$, some plants can accumulate as much as $10,000 \mathrm{mg} / \mathrm{kg}$ when they are grown in high-selenium regions. These high-accumulating plants are generally not used as food sources but can produce toxic effects in livestock. 


\section{Toxicity of selenium}

Selenium is an essential nutrient. The adult RDA is 0.0006 to $0.0011 \mathrm{mg} / \mathrm{kg}$-day. Although some biochemical alterations (including prolonged prothrombin time and reduced blood glutathione concentrations) can be observed with selenium intakes from 0.0107 to $0.0121 \mathrm{mg} / \mathrm{kg}$-day, no clinical signs of selenosis are observed with these intakes. Mild toxicity, including hair loss or breakage, thickening and brittle nails, and a garlic odor in dermal excretions and breath, were reported in human populations with a dietary selenium intake of $0.015 \mathrm{mg} / \mathrm{kg}$-day. However, selenium intake as low as $0.013 \mathrm{mg} / \mathrm{kg}$-day can produce symptoms of selenosis such as hair and nail loss in susceptible populations.

Persistent clinical selenosis is caused by the chronic dietary selenium intake of human populations living in areas of China with high selenium concentrations in soil (from 7 to $12 \mathrm{mg} / \mathrm{kg}$ soil). Estimated selenium dietary intake was reportedly 0.018 and $0.021 \mathrm{mg} / \mathrm{kg}$-day for women and men respectively (Yang et al., 1989a; $1989 \mathrm{bl}$. The average blood selenium concentration associated with this intake of selenium was $1.3 \mathrm{mg} / \mathrm{L}$ (ranging from $1.05 \mathrm{mg} / \mathrm{L}$ to $1.85 \mathrm{mg} / \mathrm{L}$ ). Symptoms of chronic selenosis with hair and nail loss and below-normal hemoglobin levels were reported in the same study (selenium intake of $0.071 \mathrm{mg} / \mathrm{kg}$-day). A serious outbreak of selenium poisoning, including the possible occurrence of neurotoxic effects such as peripheral anesthesia, acroparesthesia, and pain in extremities, was observed with selenium intake of $0.54 \mathrm{mg} / \mathrm{kg}$-day in both women and men. It is important to note that protein intake by members of this population is unknown. These health effects are summarized in Figure 5.7 as a function of dose.

Ingestion of 350 to $4300 \mathrm{mg}$ of selenium by adults has produced vomiting, diarrhea, abdominal cramps, numbness in arms, and marked hair loss and irregular menstrual bleeding in women. Higher intakes can result in unsteady gait, cyanosis of mucous membranes, labored breathing, and sometimes death.

Symptoms of "alkali disease and blind staggers" are seen in livestock grazing long term on selenium-accumulating plants in areas with high soil selenium content (Rosenfeld and Beath, 1964). These symptoms include neurological dysfunctions such as impaired vision, ataxia, disorientation, and respiratory distress.

\subsubsection{Sodium}

\section{Absorption}

Sodium is rapidly and fully absorbed from the intestinal tract. The skin and lungs also absorb sodium rapidly, by simple diffusion and ion exchange. Sodium travels in the blood, where it ultimately passes through the kidneys. The kidneys filter out all sodium; then, with great precision, the adrenal hormone aldosterone maintains the correct sodium concentration in the bloodstream (NRC, 1980). 


\begin{tabular}{llllll|ll|l}
\hline & 0.0025 & 0.005 & 0.0075 & $\begin{array}{c}0.01 \\
\text { (mg/kg-day) }\end{array}$ & 0.0125 & 0.015 & 0.0175 & 0.020
\end{tabular}

$$
\text { LUTPITIO }
$$

NUTRITIONAL INTAKE LEVELS

$\underbrace{}_{\text {DIETARY INTAKE LEVELS }}$

$\triangle$ Oral REFERENCE DOSE (0.005 mg/kg-day)

\section{$\cdots \cdots \overline{\text { NO OBSERVED EFFECT LEVEL }} \cdots$}

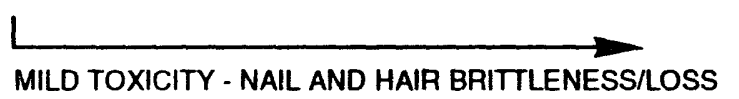

FIGURE 5.7

SELENIUM TOXICITY RANGES 


\section{Tissue accumulation and clearance}

Sodium is the major extracellular ion. The sodium ion is essential to the regulation of the acid-base balance and is an important contributor to extracellular osmolarity. It is an essential constituent in the electrophysiological functioning of cells and is required for the propagation of impulses in excitable tissues. Furthermore, sodium is essential for active nutrient transport, including the active transport of glucose across the intestinal mucosa. About 30 to 40 percent of the body's sodium is thought to be stored on the surfaces of the bone crystals, where it is easily recovered if blood sodium levels drop.

Sodium is excreted mainly in urine, with appreciable amounts also excreted in feces, sweat, and tears (Venugopal and Luckey, 1978). Mammalian renal sodium excretion is a two-phase process involving glomerular filtration and reabsorption in proximal tubules; of about 600 grams of sodium involved in 24-hour glomerular filtration, approximately 99.5 percent is reatsorbed in human adults. A homeostatic mechanism for sodium functions at the renal excretory level.

\section{Environmental sources of sodium}

The total sodium intake is influenced mainly by the amount of salt (sodium chloride) added to food, the inherent salt content of the foods consumed, and the amount of other sodium salts in the diet and in medication. Sodium is a natural constituent of both vegetable and animal products in varying concentrations. Other sources of sodium are drinking water, cooking water, soft drinks, and alcoholic beverages.

At 2 months, infants consume approximately $300 \mathrm{mg}$ of sodium a day; at 12 months, approximately $1400 \mathrm{mg}$ a day. Human milk contains $161 \mathrm{mg} / \mathrm{L}$ and cow's milk contains approximately $483 \mathrm{mg} / \mathrm{L}$ (Carson et al., 1986).

No RDA is set for sodium. The National Research Council recommends limiting daily sodium intake to less than $2400 \mathrm{mg}(34 \mathrm{mg} / \mathrm{kg}$-day). A healthy person requires about $115 \mathrm{mg}$ sodium daily $(1.6 \mathrm{mg} / \mathrm{kg}$-day), yet sodium dietary intake is estimated at 57 to $85 \mathrm{mg} / \mathrm{kg}$-day. However, dietary sodium intakes as high as 134 $\mathrm{mg} / \mathrm{kg}$-day are reported (NRC, 1980). The American Heart Association recommends limiting dietary sodium intake to $3000 \mathrm{mg}$ daily.

The sodium content of drinking water is extremely variable. Analyses of water supply systems indicated sodium concentrations in 630 systems ranged from less than 1 to $402 \mathrm{mg} / \mathrm{L}$ (resulting in drinking water ingestion rates from less than 0.03 to $11 \mathrm{mg} / \mathrm{kg}$-day), with 42 percent greater than $20 \mathrm{mg} / \mathrm{L}$ and 3 percent over $200 \mathrm{mg} / \mathrm{L}$ (Carson et al., 1986).

\section{Toxicity of sodium}

Acute toxicity symptoms from sodium chloride in healthy adult males accompanied by visible edema may occur with an intake as low as 35 to 40 grams of salt per day $(20$ to $23 \mathrm{mg}$ sodium $/ \mathrm{kg}$-day since sodium is 39 percent of the weight of 
sodium chloride) (Meneely and Battarbee, 1976). The mean lethal dose of sodium for humans is reportedly $3230 \mathrm{mg} / \mathrm{kg}$ (Venugopal and Luckey, 1978).

Epidemiological studies indicate that long-term, excessive sodium intake is one of many factors associated with hypertension in humans. A high sodium/potassium ratio in the diet may be detrimental to persons susceptible to high blood pressure. Some adults, however, tolerate chronic intake above 40 grams of sodium chloride per day (equivalent to $23 \mathrm{mg} / \mathrm{kg}$-day) (Carson et al., 1986).

Research indicates that critical levels of sodium ingestion cause blood pressure to rise with age and that some people develop hypertension. Freis (1976) reports that with sodium intake below $227 \mathrm{mg} / \mathrm{day}(3 \mathrm{mg} / \mathrm{kg}$-day for a 70-kg adult), hypertension was absent. In the range of 227 to $1591 \mathrm{mg} /$ day 13 to $23 \mathrm{mg} / \mathrm{kg}$-day for a $70-\mathrm{kg}$ adult), a few cases of hypertension may appear, while in the range of 1590 to $8000 \mathrm{mg} /$ day (23 to $114 \mathrm{mg} / \mathrm{kg}$-day for a 70-kg adult), approximately 15 percent of adults exhibit hypertension. When sodium intake rises above 8000 $\mathrm{mg} / \mathrm{day}$, hypertension may be found in about 30 percent of the population. Because sodium chloride is present in nearly all processed and packaged foods, limiting dietary intake is difficult. The average daily intake in the United States (from diet) often causes hypertensive effects. Drinking water generally contains relatively low levels of sodium, and therefore does not significantly contribute to the total intake unless sodium is at higher-than-average levels in the water supply. However, people on sodium-restricted diets can obtain a significant portion of daily sodium from drinking water. Because the kidney is the major organ involved in regulating sodium balance, individuals with compromised kidney function may be placed on a low-sodium diet. Other individuals may be on low-sodium diets to control hypertension. Because of the high prevalence of such individuals in our society, the American Heart Association has proposed that public drinking water supplies in the United States adopt a standard of $20 \mathrm{mg} / \mathrm{L}$ sodium (Calabrese and Tuthill, 1977). This measure would limit the additional intake of sodium from drinking water to approximately $0.6 \mathrm{mg} / \mathrm{kg}$-day for a $70-\mathrm{kg}$ adult. Figure 5.8 summarizes the potential health effects of sodium as a function of dose.

\subsubsection{Strontium}

The strontium isotopes present at UMTRA Project sites are all natural, stable isotopes. The radioactive element strontium-90 does not occur naturally and is produced only as a product of fission reactions. Therefore, no radiation exposure is associated with the presence of strontium at UMTRA Project sites.

\section{Absorption}

In humans, 14 to 50 percent of an orally administered dose of strontium is absorbed; peak blood levels occur within 4 hours. Absorption is proportional to dose, although large doses may overwhelm homeostatic mechanisms. Strontium is absorbed by passive diffusion from the intestinal lumen (Comar and Wasserman, 1964). Because of their chemical resemblance, strontium can effectively displace calcium. In cases of dietary calcium deficiency, strontium is 


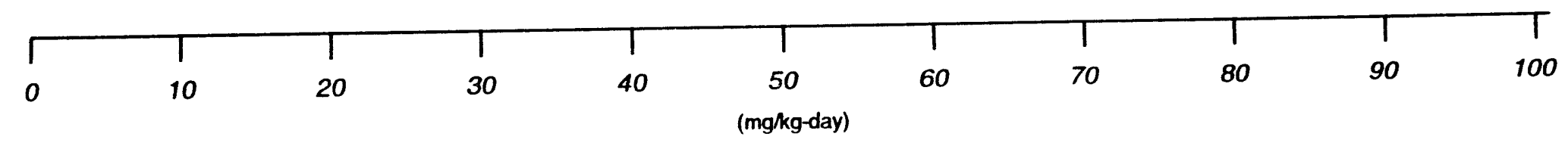

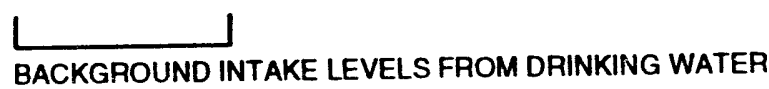

A nutritional requirement 
absorbed to a higher degree. The bioavailability of ingested strontium is estimated to be 20 percent, depending on age, species, form of strontium, and dietary levels of phosphorus, vitamin D, and calcium.

\section{Tissue accumulation and clearance}

Because of its strong similarity to calcium, 99 percent of the body burden of strontium is found in bone. The average adult body burden of strontium is estimated to be $320 \mathrm{mg}$ (Snyder et al., 1975). Absorbed strontium is cleared primarily through urine and feces. In humans, 12 to 13 percent of an intravenous dose is eliminated in the feces. Urinary excretion accounts for elimination of nearly 60 percent of an intravenous dose and 4 to 18 percent of an oral dose (EPA, 1990). Although strontium is filtered by the kidney at a rate 3.5 times greater than calcium, calcium is reabsorbed more efficiently than strontium. resulting in a more rapid clearance of strontium.

\section{Environmental sources of strontium}

Normal dietary intake of strontium in adult humans ranges from 0.013 to $0.021 \mathrm{mg} / \mathrm{kg}$-day. Stable strontium is reported in drinking water supplies in Wisconsin and Ohio at concentrations ranging from 0.02 to $34.5 \mathrm{mg} / \mathrm{L}$ (Curzon, 1985). Strontium has been used medicinally since 1884 , although its medicinal use has steadily declined.

\section{Toxicity of strontium}

No data are available on the acute toxicity of stable strontium in humans. The range of lethal doses for orally administered strontium varied across species from a lethal dose of $1826 \mathrm{mg} / \mathrm{kg}$ for 50 percent of experimental mice to a lethal dose of $7500 \mathrm{mg} / \mathrm{kg}$ in rabbits (EPA, 1990). Death resulted from respiratory failure. Intravenous administration decreased the toxic dose by as much as an order of magnitude $(148 \mathrm{mg} / \mathrm{kg}$ in mice).

No good data are available for estimating the toxic effects of long-term excess stable strontium intake. Strontium was administered in the treatment of osteoporosis at a dose of $24 \mathrm{mg} / \mathrm{kg}$-day for as long as 3 years (McCaslin and Janes, 1959). Although no side effects were observed, the bone loss occurring in these patients makes it difficult to compare their response to what might be observed in a healthy population.

In rat studies, strontium toxicity is related to its displacement of calcium in bone; this toxicity differs with the developmental stage of the animals. The lowest intake level observed to produce toxicity in young rats was $380 \mathrm{mg} / \mathrm{kg}$-day of strontium carbonate. This dose inhibited calcification of the epiphyseal plate after 3 weeks of exposure. In adult rats, this dose had no effect, but a much larger epiphyseal plate was observed following intake of 750 or $1500 \mathrm{mg} / \mathrm{kg}$-day in the adult animals (Storey, 1961 ). Intake of $190 \mathrm{mg} / \mathrm{kg}$-day resulted in no observed toxicity in the young rats. In weanling rats, drinking $633 \mathrm{mg} / \mathrm{kg}$-day of strontium chloride in water 
resulted in slower mineralization of the bone, slower calcification, and defective long-bone growth (Marie et al., 1985). No toxicity was observed in the weanling animals at $525 \mathrm{mg} / \mathrm{kg}$-day intake of strontium chloride. These health effects are summarized in Figure 5.9 as a function of dose.

\subsubsection{Sulfate}

\section{Absorption}

Sulfate absorption from the gastrointestinal tract is similar in humans and other animals. Generally, greater than 90 percent absorption is reported for sulfate doses below $150 \mathrm{mg} / \mathrm{kg}$, decreasing to 50 to 75 percent as the dose increases into the grams-per-kilogram range.

\section{Tissue accumulation and retention}

Ingesting high levels of sulfate results in transient increases in both blood and urine concentrations. For sulfate doses of approximately $75 \mathrm{mg} / \mathrm{kg}$, approximately 50 percent of the dose is excreted over 72 hours. The urinary excretion mechanism is transport-limited and can therefore become saturated at high doses of sulfate. Excess sulfate is also excreted in feces in its inorganic form. To date, no data indicate sulfate is accumulated, even with chronic ingestion of above-normal levels. However, extremely high chronic doses have not been examined in humans.

Sulfate is used in the biosynthesis of collagen, cartilage, and dentin and in the formation of sulfate esters of both endogenous compounds (such as lipids and steroids) and exogenous compounds (such as phenols). Sulfation is important in detoxication pathways because it increases the solubility of these compounds, which enhances their excretion in the urine. Exposure to high concentrations of compounds that are conjugated with sulfate and excreted can produce a transient decrease in plasma sulfate concentrations.

\section{Environmental sources of sulfate}

Drinking water sulfate concentrations in the western United States in 1978 ranged from $O$ to $820 \mathrm{mg} / \mathrm{L}$, with a mean concentration of $99 \mathrm{mg} / \mathrm{L}$. The EPA estimates a normal sulfate intake range of 0.00023 to $0.0064 \mathrm{mg} / \mathrm{kg}$-day from air and up to $2.9 \mathrm{mg} / \mathrm{kg}$-day from drinking water in the western United States. No estimates are available on sulfate intake from food.

\section{Toxicity of sulfate}

As with nitrate toxicity, the acute and chronic effects of sulfate toxicity differ more in severity than in symptoms or mechanisms. Therefore, this discussion will combine acute and chronic toxicity. As mentioned above, no data indicate sulfate bioaccumulation with chronic exposure. Sulfate salts of magnesium and sodium are used medicinally as cathartics. High concentrations of unabsorbed 


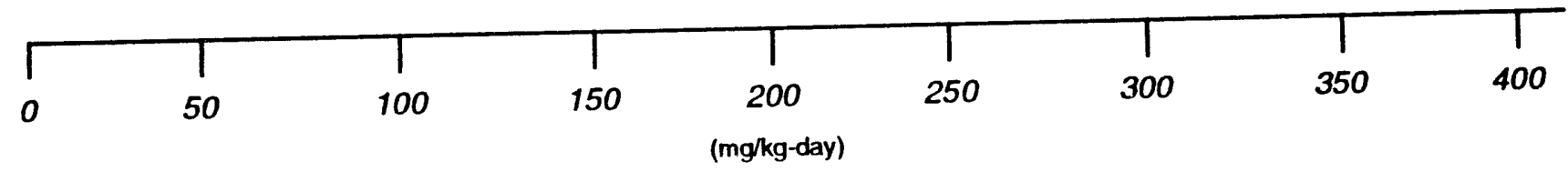

DIETARY INTAKE LEVELS

O oral reference dose (0.6 mg/kg-day)

NO OBSERVED SIDE-EFFECTS IN TREATED HUMANS

NÖOBSERVED EFFEĊTS IN YOUNG RATS'

MIID TOXICITY (RATS)

FIGURE 5.9

STRONTIUM TOXICITY RANGES 
sulfate salts in the gut can pull large amounts of water into the gut, greatly increasing the normal volume of feces. This is the basis of the toxic effects as well.

Toxicity in humans is primarily manifested in diarrhea; the severity of the diarrhea is dose-dependent. Chronic sulfate ingestion can result in persistent diarrhea, leading to ionic imbalance and dehydration similar to that seen with extremely high acute doses. Serious gastroenteritis is reported in some infants and adults drinking water containing 400 to $1000 \mathrm{mg} / \mathrm{L}$ sulfate (EPA, 1992a). When drinking water is contaminated with sulfate, the taste of the water may make it unpalatable and reduce consumption. However, this is not necessarily the case. In regions (such as Saskatchewan) with high sulfate concentrations in the drinking water, residents adapt to the taste and find the water palatable (EPA, 1992a). A lower water intake could compound the dehydration effects of the diarrhea. Extreme dehydration can lead to death. As with nitrate toxicity, infants seem to be the most susceptible population for sulfate-induced diarrhea. Also, some data indicate diabetic and elderly populations with compromised kidney function may be more sensitive than healthy adults to the effects of sulfates (EPA, 1992a). These health effects are summarized in Figure 5.10 as a function of dose.

In cattle, high sulfate intake results in sulfhemoglobinemia, a condition similar to the methemoglobinemia induced by nitrate ingestion (EPA, 1992a). Sulfhemoglobinemia has not been reported following ingestion of sulfate by humans, although the condition has been reported in humans following inhalation of hydrogen sulfide.

As with nitrate, data on sulfate toxicity are based primarily on epidemiologic studies of human adults and infants who report to hospitals with symptoms of sulfate exposure. In most cases, exposure doses have been back-calculated from sampling their drinking water. Therefore, these data do not represent well-controlled studies with readily defined dosage ranges.

\subsubsection{Uranium}

The uranium that occurs naturally at UMTRA Project sites consists of three radioactive isotopes: uranium-234, uranium-235, and uranium-238. More than 99 percent of natural uranium occurs in the form of uranium-238 (Cothern and Lappenbusch, 1983). Uranium-238 undergoes radioactive decay by emitting alpha particles to form uranium-234, thorium-230, radium-226, radon 222, polonium-210, and other radioisotopes. The radioactive decay chain of uranium238 and uranium-234 is summarized in Figure 5.11. As all natural uranium isotopes are radioactive, the hazards of a high uranium intake are from both its chemical toxicity and potential radiological damage. This section focuses on the chemical toxicity of natural uranium. The carcinogenic potential associated with exposure to radioactive isotopes of natural uranium is discussed in Section 5.3. 


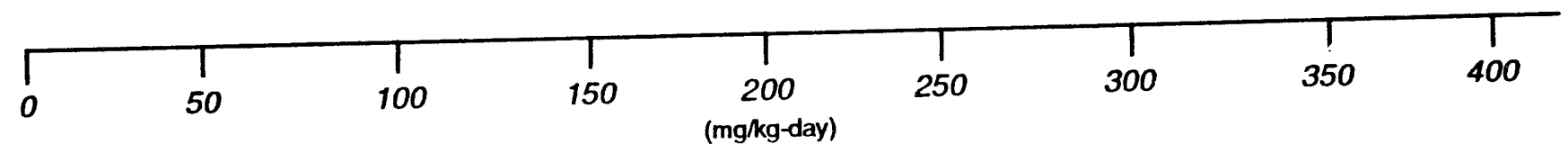

U

BACKGROUND INTAKE LEVELS

NO OBBSERVED EFFECTS

2.. TOXICITY RANGING FROM LAXATIVE EFFECT (ADULTS) TO DIARRHEA IN INFANTS

SËVERE TOXICITY - PERSISTENT INFANT DIARRHEA LEADING TO DEHYDRATION

FIGURE 5.10

SULFATE TOXICITY RANGES 


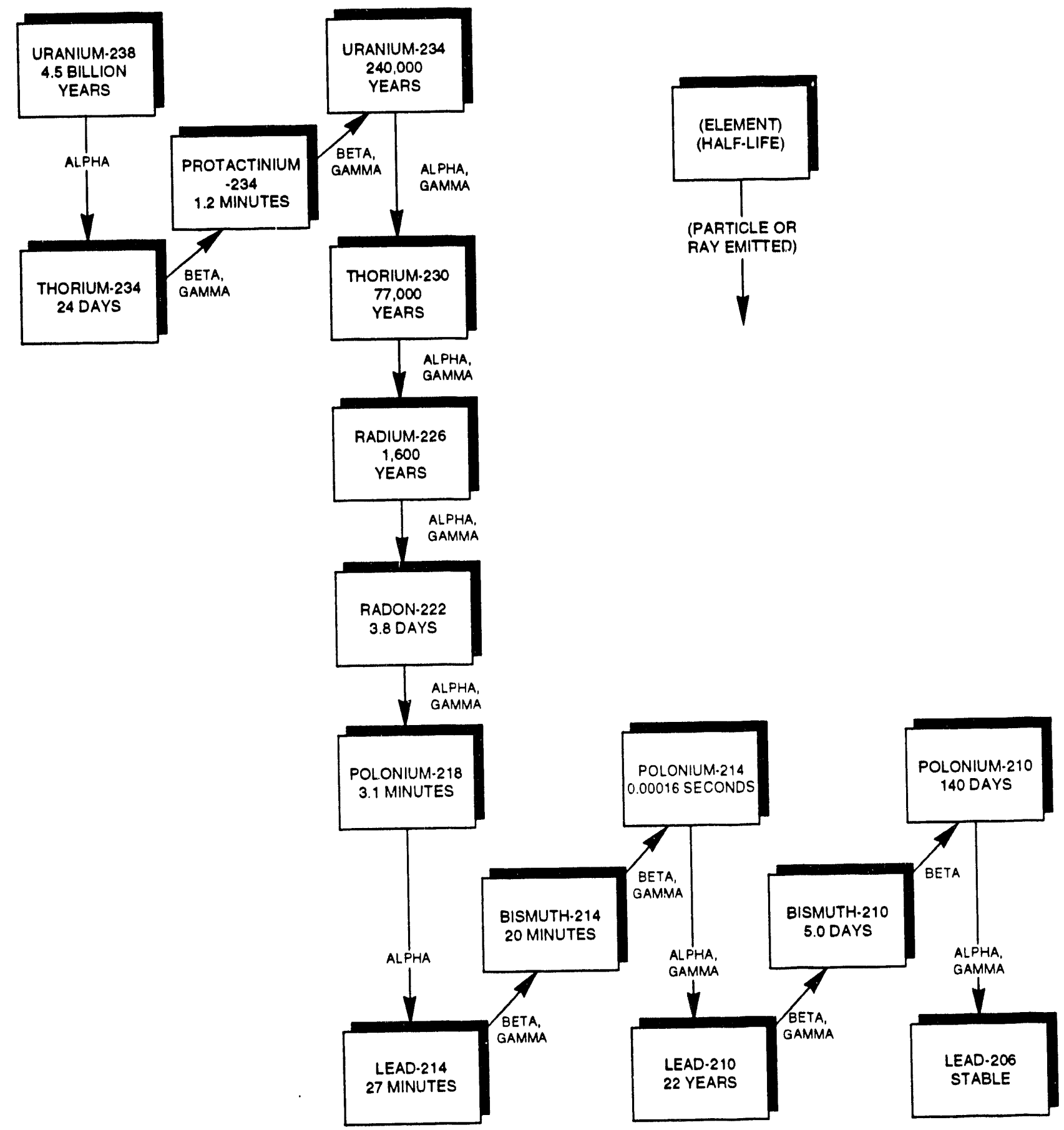

FIGURE 5.11

HALF-LIVES AND EMISSIONS FROM DECAY CHAIN OF URANIUM-238 


\section{Absorption}

Absorption of uranium in the gastrointestinal tract depends on the solubility of the uranium compounds. The hexavalent uranium compounds, especially the uranyl salts, are water soluble, while tetravalent compounds generally are not (Weigel, 1983). Even with soluble compounds, only a small fraction is absorbed. Human gastrointestinal absorption rates of 0.76 to 7.8 percent have been determined (Wrenn et al., 1985).

\section{Tissue accumulation and clearance}

In humans exposed to background levels of uranium, the highest concentrations were found in the bones, muscles, lungs, liver, and kidneys (Fisenne et al., 1988). Uranium retention in bone consists of a short retention half-time of 20 days, followed by a long retention half-time of 5000 days for the remainder (Tracy et al., 1992).

In body fluids, uranium tends to convert into water-soluble hexavalent uranium (Berlin and Rudell, 1986). Approximately 60 percent of the uranium in plasma complexes with low-molecular-weight anions (e.g., bicarbonates, citrates), while the remaining 40 percent binds to the plasma protein transferrin (Stevens et al., 198(1). Following oral exposure in humans, more than 90 percent of uranium is excreted in the feces and is not absorbed in the gastrointestinal tract. Of the small percent that is absorbed (typically less than 5 percent), approximately 60 percent is excreted in the urine within 24 hours and 98 percent is excreted within 7 days, based on animal studies (Ballou et al., 1986; Leach et al., 1984; Sullivan et al., 1986). A small portion of the absorbed uranium is retained for a longer period.

\section{Environmental sources of uranium}

Uranium is a ubiquitous element, present in the earth's crust at approximately 4 parts per million. Uranium concentrations in ground water and surface water averaged 1 picocurie per liter (pCi/L) and $3 \mathrm{pCi} / \mathrm{L}$, respectively (NCRP, 1984). The extent of absorption from the soil into plant tissues depends on the plant species and the depth of its root system (Berlin and Rudell, 1986). Plant uranium concentrations averaged $0.075 \mu \mathrm{g} / \mathrm{kg}$ of fresh plant material (Tracy et al., 1983).

The main dietary source of natural uranium for the general population is food (e.g., potatoes, bakery products, meat, and fresh fish) which may contain uranium concentrations between 10 and $100 \mu \mathrm{g} / \mathrm{kg}$ (Prister, 1969). The total uranium dietary intake from the consumption of average foods is approximately $1 \mu \mathrm{g} /$ day; additionally, approximately 20 to 50 percent of that total can come from drinking water. Cereals and vegetables, particularly root crops, are likely to contribute most to daily uranium intake (Berlin and Rudell, 1986). 


\section{Toxicity of uranium}

Exposure of the general public to natural uranium is unlikely to pose an immediate lethal threat to humans. No human deaths have been reported that are definitely attributable to uranium ingestion; therefore, no lethal dose has been determined for humans. Lethal doses of uranium $\left(\operatorname{LD}_{50,23}\right)$ are reported to be as low as 14 $\mathrm{mg} / \mathrm{kg}$-day following 23-day oral exposures, depending on the solubility of the uranium compound tested (higher solubility compounds have greater toxicity), route of exposure, and animal species. High doses of uranium cause complete kidney and respiratory failure.

No chronic toxic effects are reported in humans following oral exposure to uranium. Data from populations occupationally exposed to high concentrations of uranium compounds through inhalation and information from studies in experimental animals indicate the critical organ for chronic uranium toxicity is the proximal tubule of the kidney (Friberg et al., 1986a). In humans, chemical injury reveals itself by increased catalase excretion in urine and proteinuria. Doseresponse data for the toxic effects of uranium on the human kidney are limited.

The lowest dose of uranyl nitrate that caused moderate renal damage was given to rabbits in diet at $2.8 \mathrm{mg} / \mathrm{kg}$-day (Maynard and Hodge, 1949). The health effects for uranium are summarized in Figure 5.12 as a function of dose.

\subsection{CONTAMINANT INTERACTIONS}

Some information is available on potential interactions between contaminants found at UMTRA sites. However, discussions of potential interactions can generally be presented only qualitatively. In addition to physiological variabilities that can affect toxicity, two types of interaction uncertainties also result 1$)$ from differences in the relative exposure concentrations of the different contaminants compared to the concentrations tested experimentally; and 2) from the presence of additional ground water constituents that may be present in sufficient quantities to modify predicted toxicities even though they themselves are not considered contaminants of concern for human health. Therefore, the interactions described below should be recognized as factors that can influence the predicted toxicity, although the precise nature and magnitude of that influence cannot be determined.

Of primary concern among the contaminants in ground water at Shiprock is the potential for nitrate-sulfate interactions. As discussed above, no clear data are available to assess these interactions, but the epidemiological evidence suggests that in infants, gastrointestinal upset such as that caused by sulfate could increase the sensitivity of infants to methemoglobinemia produced by nitrates. However, it is also possible that sulfate-induced diarrhea could decrease the nitrate-reducing bacteria in the intestine, thereby causing a decreased nitrate toxicity. 


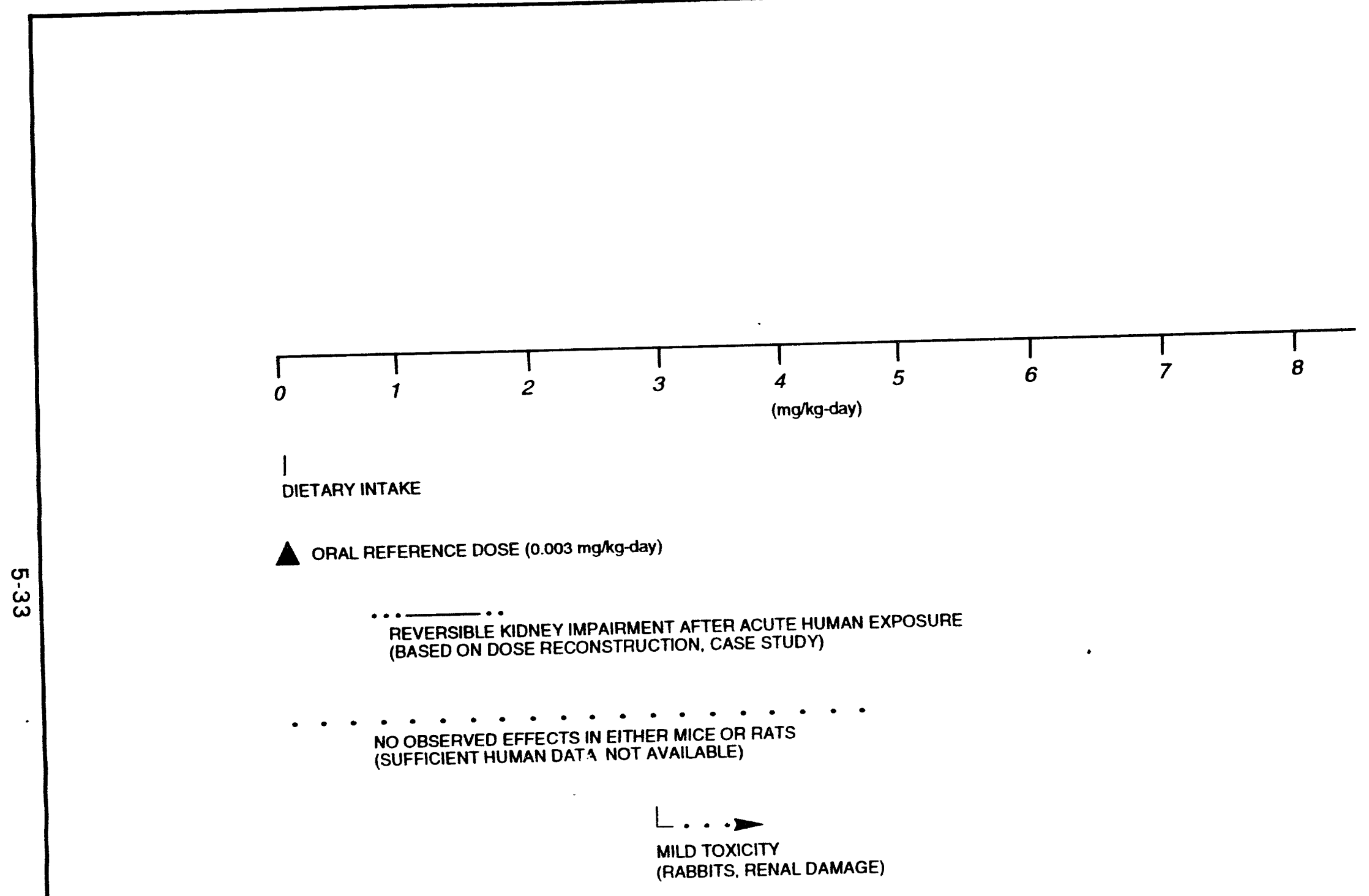

FIGURE 5.12

URANIUM TOXICITY RANGES 
Interactions between nitrate, sulfate, and hemoglobin also occur. However, no studies have been found that address the potential interactions in a combined exposure to high concentrations of both nitrate and sulfate. Nitrate has been used in the treatment of hydrogen sulfide poisoning. The hydrosulfide anion binds to methemoglobin to form sulfmethemoglobin, effectively removing circulating hydrosulfide. Additional data are needed to assess the likelihood of hydrosultide formation with oral sulfate exposure or the subsequent formation or stability of sulfmethemoglobin.

Interactions between several similar metals can alter the predicted absorption, distribution in the body, metabolism, toxicity, or clearance of a metal of interest. For example, cadmium and manganese absorption can be considerably increased under conditions of low intake of calcium, iron, or protein (Nordberg et al., 1985). Low body iron stores can increase cadmium uptake fourfold (Flanagan et al., 1978). Similarly, absorption of manganese from the intestine may significantly increase in the presence of low dietary iron, leading to increased toxicity of manganese (DHHS, 1992). However, high levels of cadmium may inhibit manganese absorption. Additionally, cadmium and manganese can induce synthesis of the metal-binding protein metallothionein (DHHS, 1992; Casarett and Doull, 1991). This protein seems to have a paradoxical effect on the systemic toxicity of cadmium. Metallothionein appears to bind cadmium and in this way protect certain organs such as the testes from cadmium toxicity. But at the same time, metallothionein may enhance cadmium nephrotoxicity, possibly because the cadmium-metallothionein complex is taken up by the kidney more readily than is the free ion. However, in the continued presence of these other metals, there may be competition for metallothionein binding sites.

Strontium toxicity is strongly influenced by calcium intake. Toxicity is enhanced in low calcium conditions and decreased in the presence of high calcium.

Selenium interacts with a wide range of metals, including arsenic, bismuth, cadmium, cobalt, copper, lead, mercury, platinum, silver, tellurium, and thallium (Friberg et al., 1986a). Selenium forms insoluble complexes with silver, copper, cadmium, and mercury. Selenium deficiency may develop in the presence of these other metals, as is seen with cobalt and copper. The formation of these complexes can reduce the toxicity of both selenium and the other metal (Casarett and Doull, 19911. Most of these interactions have been observed in laboratory animals or in livestock. The mechanisms are not completely understood in many cases. Often the selenium-metal complex binds in a stable complex to a larger protein than the metal alone, and a redistribution of this complex occurs away from target tissues. Selenium and arsenic together can reduce their respective toxicities. However, some methylated metabolites of selenium can increase arsenic toxicity (DHHS, 1989). Sulfate can also interact with selenium, but the interaction is inconsistent. Sulfate can reduce some toxic effects of selenium but not others, such as liver damage, at high doses (DHHS, 1989).

Because ingesting high levels of sulfate produces diarrhea that will led to dehydration and ingesting high levels of sodium leads to fluid retention, a 
physiological interaction might be expected to occur with simultaneous ingestion of both. However, no data are available to predict the net effect of chronic ingestion of sulfate and sodium at high concentrations. In addition, use of highconcentration sodium solutions in the treatment of diarrhea-induced hyponatremia utilizes solutions with physiologically balanced electrolyte concentrations.

Disproportionately high sodium levels could intensify the electrolyte loss produced by severe diarrhea. No information on uranium interactions with other metals has been found. However, the common target organ suggests interaction with cadmium and magnesium produces greater kidney toxicity.

\subsection{CONTAMINANT RISK FACTORS}

The EPA Office of Research and Development calculates acceptable intake values, or RfDs, for long-term (chronic) exposure to noncarcinogens. These values are estimates of route-specific exposure levels that would not be expected to cause adverse health effects when exposure occurs for a significant portion of a lifetime. The RfDs include safety factors to account for uncertainties associated with limitations of the toxicological data base, including extrapolating anımal studies to humans and accounting for response variability from sensitive individuals. These values are updated quarterly and are published in the Health Effects Assessment Summary Tables (HEAST). They are also provided through the EPA's IRIS data base. The most recent oral RfDs for the noncarcinogenic contaminants of concern are summarized in Table 5.2.

The EPA currently classifies all radionuclides as Group $A$, or known human carcinogens, based on their property of emitting ionizing radiation and on the evidence provided by epidemiological studies of radiation-induced cancer in humans. At sufficiently high doses, ionizing radiation acts as a complete carcinogen (both as initiator and promoterl, capable of increasing the probability of cancer development. However, the actual risk is difficult to estimate, particularly for the low doses and dose rates encountered in the environment. Most reliable data were obtained under conditions of high doses delivered acutely. It is not clear whether cancer risks at lower doses are dose proportional (i.e., the linear dose-response hypothesis) or whether the risk is greatly reduced at low doses and rates (the threshold hypothesis). A conservative assumption is that no threshold dose exists below which there is no additional risk of cancer.

Risk factors published in HEAST and IRIS correlate the intake of carcinogens over a lifetime with the increased excess cancer risk from that exposure. The most recent cancer slope factors for the uranium-234/-238 radioactive decay series and arsenic are given in Table 5.1. 
Table 5.2 Toxicity values: potential noncarcinogenic effects

\begin{tabular}{|c|c|c|c|c|c|}
\hline Chemical & $\begin{array}{c}\text { Chronic oral RfD } \\
\text { (mg/kg-day) }\end{array}$ & $\begin{array}{c}\text { Confidence } \\
\text { level }\end{array}$ & Critical effect/organ & $\begin{array}{l}\text { RfD basis/RfD } \\
\text { source }\end{array}$ & $\begin{array}{l}\text { Uncertainty } \\
\text { factor }\end{array}$ \\
\hline Antimony & 0.0004 & Low & $\begin{array}{l}\text { Increased mortalit\%, altered blood } \\
\text { chemistries }\end{array}$ & Water/HEAST & 1000 \\
\hline Arsenic inorganic & 0.0003 & High & Keratosis, hyperpigmentation & Water/HEAST & 3 \\
\hline Cadmium & 0.0005 & High & Kidney & Water/HEAST & 10 \\
\hline Magnesium & NA & High & $\begin{array}{l}\text { Diarrhea, central nervous system } \\
\text { depression, methemoglobinemia }\end{array}$ & Water/Diet/NA & NA \\
\hline Manganese & 0.005 & $\begin{array}{l}\text { Medium to } \\
\text { Low }\end{array}$ & Central nervous system & Water/IRIS & 1 \\
\hline Nitrate & $7.0^{\mathrm{a}}$ & High & Methemoglobinemia, hematologic & Water/IRIS & 1 \\
\hline Sodium & NA & High & Hypertension & Water/Diet/NA & NA \\
\hline Selenium & 0.005 & High & Hair, nail, and skin & Diet/IRIS & 3 \\
\hline Strontium & 0.6 & Medium & Bone & Water/IRIS & 300 \\
\hline Sulfate & NA & High & Diarrhea & Water/NA & NA \\
\hline $\begin{array}{l}\text { Uranium } \\
\text { (soluble salts) }\end{array}$ & 0.003 & Medium & Kidney, decreased body weight & Water/IRIS & 1000 \\
\hline
\end{tabular}

${ }^{a}$ Value represented as nitrate; nitrate - nirogen RfD is $1.6 \mathrm{mg} / \mathrm{kg}$-day.

NA - not available. 


\subsection{HUMAN HEALTH RISK EVALUATION}

To evaluate health risks to an individual or population, the results of the exposure assessment are combined with the results of the toxicity assessment. As discussed in Section 5.0, potential adverse health effects are a function of how much of the contaminant an individual takes into his or her body. At lower levels, many contaminants associated with the mill tailings are beneficial to health, because they are essential nutrients. At higher levels, these same elements can cause adverse health effects and at very high levels, death. In this section, the estimated reasonable maximum intake, if the floodplain or terrace alluvium ground water were used, is correlated to potential health effects. Additionally, the expected intake for children potentially exposed to selected contaminants of concern while playing on the floodplain and for ingestion of meat and milk from livestock raised on the floodplain are correlated to potential health effects.

\section{I POTENTIAL NONCARCINOGENIC HEALTH EFFECTS}

\subsubsection{Floodplain ground water potential use}

The results from the exposure assessment for the floodplain ground water exposure pathways showing either the adult intake doses or the toxicologically most sensitive group are used to evaluate potential health effects for noncarcinogens. For antimony, arsenic, cadmium, magnesium, manganese, selenium, sodium, strontium, and uranium, the reasonable maximum intake-per-body-weight is estimated for the adult population. For sulfate and nitrate, infant exposures are used to evaluate health risks, since this is the toxicologically sensitive population.

The most significant health risk associated with the floodplain ground water contamınation at the Shiprock site is nitrate. As can be seen in Figure 6.1, if ground water were used for drinking water, the potential exposure is more than 10 tımes the potentially lethal level for infants.

The nitrate levels associated with lethal cases of methemoglobinemia vary considerably. Infants prone to gastrointestinal distress appear to be more sensitive than healthy infants. Therefore, the gastrointestinal effects associated with sulfate exposure could increase nitrate toxi, ity. However, sulfate-induced diarrhea also could decrease the intestinal content of nitrate-reducing bacteria, making nitrate less toxic. Likewise, these high-sulfate concentrations may cause the water to be so unpalatable to infants as to reduce their exposure. However, reduced water intake would exacerbate the impacts of dehydration. Figure 6.2 shows that the exposure for sulfate is well above the range where very severe diarrhea or even death due to dehydration would be expected. Also, some data indicate diabetic and elderly populations with compromised kidney function may be more sensitive than healthy adults to the effects of sulfates (EPA, 1992a).

Arsenic exposure levels detected in the floodplain ground water at the Shiprock site are below the levels known to produce pathologic skin lesions (Figure 6.3), but are slightly above the EPA oral RfD. Selenium and arsenic together can reduce their 


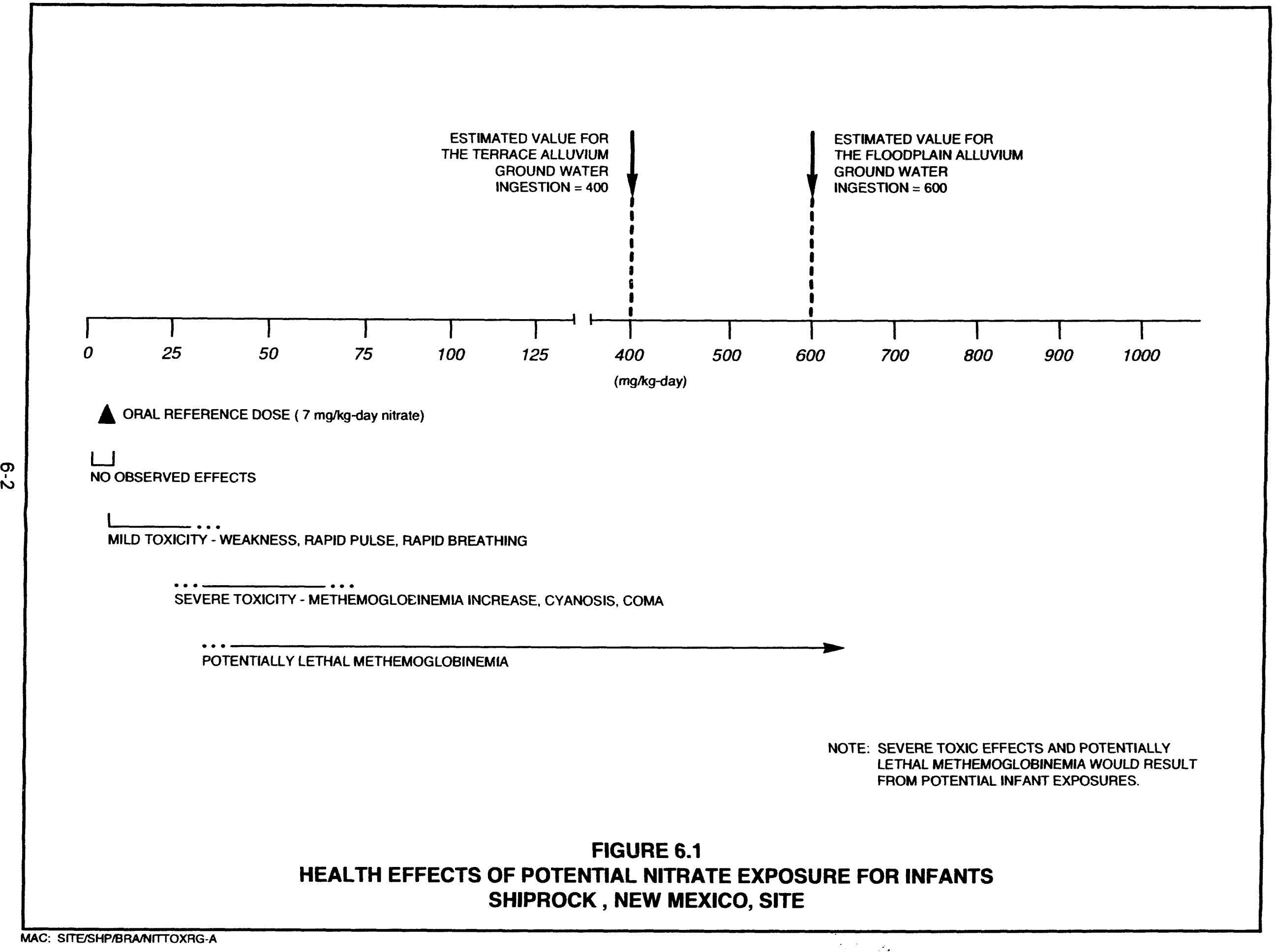




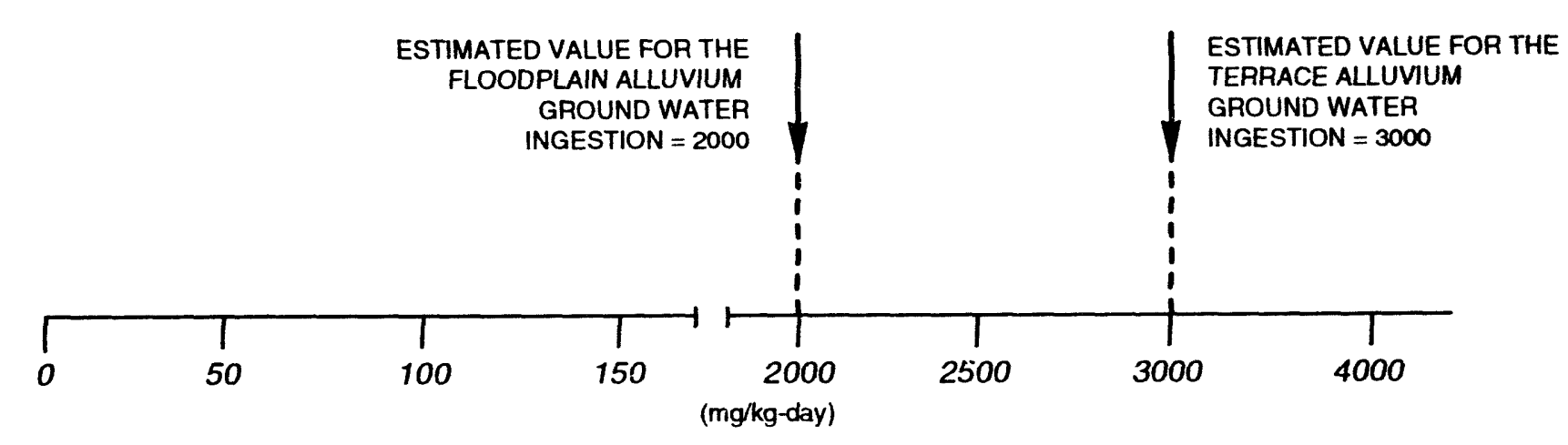

\lfloor

BACKGROUND INTAKE LEVELS

NO OBSËRVED EFFECTS

MiLD TOXICITY RANGING FROM LAXATIVE EFFECT (ADULTS) TO DIARRHEA IN INFANTS

S̈EVERE TOXICITY - PERSISTENT INFANT DIARRHEA LEADING TO DEHYDRATЮN -

DEATH

NOTE: SEVERE TOXIC EFFECTS, MANIFESTED AS PERSISTENT DIARRHEA LEADING TO DEHYDRATION AND POSSIBLY DEATH. WOULD RESULT FROM POTENTIAL INFANT EXPOSURE.

FIGURE 6.2

HEALTH EFFECTS OF POTENTIAL SULFATE EXPOSURE FOR INFANTS SHIPROCK, NEW MEXICO, STTE 


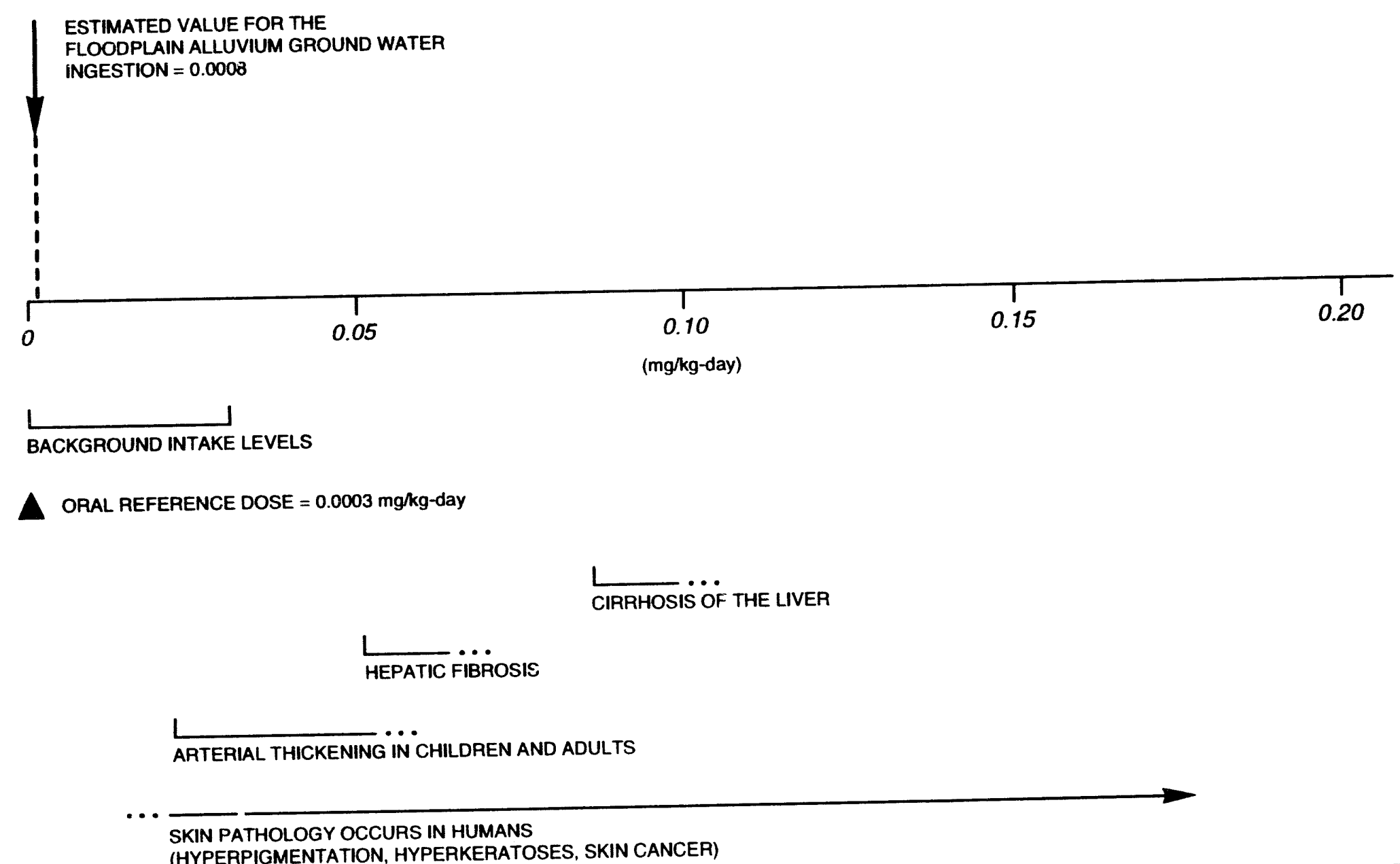

(HYPERPIGMENTATION, HYPERKERATOSES, SKIN CANCER)

NOTE: NO OBSERVED ADVERSE HEALTH EFFECTS WOULD BE ASSOCIATED WITH POTENTIAL ADULT EXPOSURES.

\author{
FIGURE 6.3
}

HEALTH EFFECTS OF POTENTIAL ARSENIC EXPOSURE FOR ADULTS SHIPROCK, NEW MEXICO, SITE 
respective toxicities. However, as was discussed in Section 5.2, the net result of this interaction is not discernible.

Cadmium, uranium, and magnesium would be expected to produce additive effects because they affect reabsorption in the proximal tubule of the kidney (Figures 6.4, 6.5 , and 6.6). This causes protein and other nutritive compounds to spill into the urine rather than be retained by the body. The cadmium levels alone detected at the Shiprock site are below the threshold level for these effects; nonetheless, the presence of cadmium, magnesium, and uranium together indicates a potential for additive effects. It should also be remembered that diabetics and the elderly may be more sensitive to cadmium toxicity due to their already impaired kidney function. Therefore, toxic effects may appear in these sensitive individuals at lower levels than presented in Section 5.0.

The estimated uranium intake at Shiprock is less than one-tenth the level of any obseived adverse health effects in human or animal studies. However, the estimated exposure is substantially (30 times) above the EPA acceptable intake level (RfD of $0.003 \mathrm{mg} / \mathrm{kg}$-day). This apparent discrepancy occurs largely because there is little toxicity information for uranium in humans. Uranium has not been demonstrated to serve a beneficial purpose in biological systems; therefore, unlike nutrient metals, a toxicity threshold is difficult to define. Because of these uncertainties, the EPA has set a very low acceptable intake level.

Magnesium exposures at these levels are associated with strong cathartic effects (Figure 6.6). There are not sufficient toxicity data to know whether these high levels are also associated with other, more severe effects.

Exposure levels for antimony and strontium detected at the site are within ranges for no observed adverse health effect in humans. However, the estimated exposure level for antimony is above the EPA oral RfD value (FIgure 6.7), whereas the estimated exposure level for strontium is below the EPA oral RfD value (Figure 6.8).

For selenium (Figure 6.9), the estimated exposure level is above the EPA oral RfD and above the upper level of the range for no ohserved adverse effects in humans. However, it falls into the exposure range between unknown toxicity in humans and the exposure level demonstrated to be associated with mild toxicity, manifested by brittle nails or hair loss. Sulfate also can interact with selenium but the interaction is inconsistent. Sulfate can reduce some toxic effects of selenium but not others, such as liver damage at high doses.

Exposure levels for manganese are determined to be above the EPA acceptable oral intake levels (RfD). This intake is approximately half the levels reported to cause neurotoxicity in humans (Figure 6.10).

The sodium exposure level is about three times the upper limit recommended by the NRC and would cause hypertension and renal impairment (Figure 6.11). It is not known if more severe effects would be associated with this high dose. 


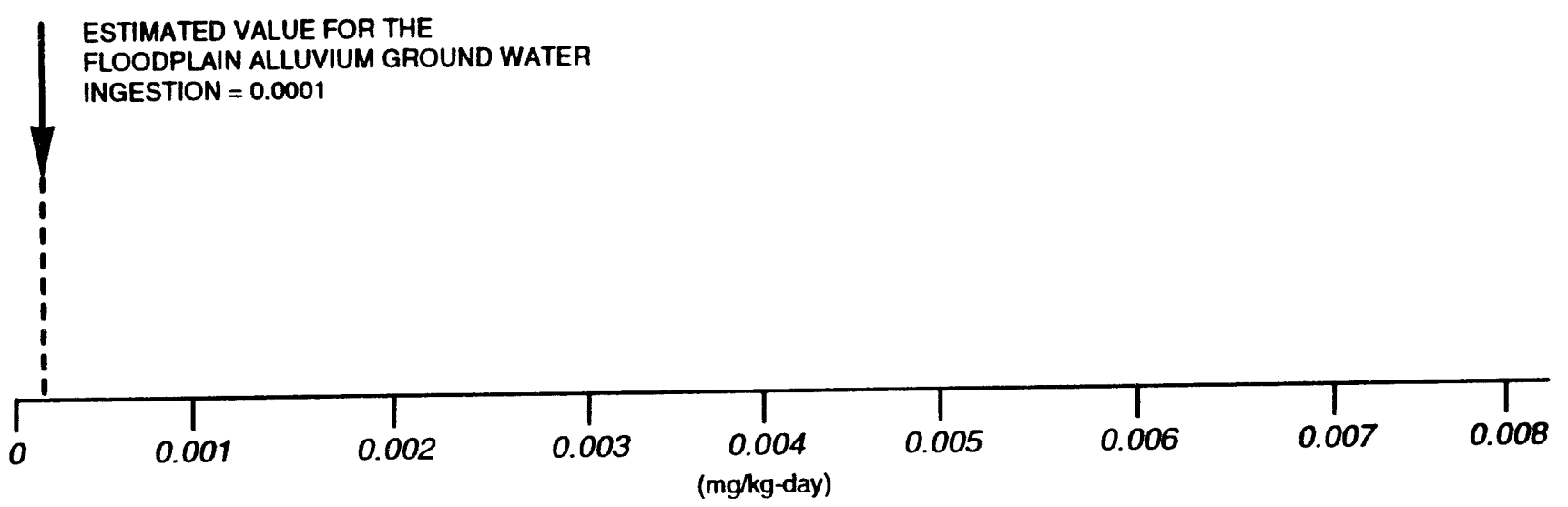

$$
\text { L }
$$

BACKGROUND INTAKE LEVELS

$\triangle$ ORAL REFERENCE DOSE, DRINKING WATER (0.0005 mg/kg-day)

NO OBSERVED EFFECTS FROM DRINKING WATER CONSUMPTION

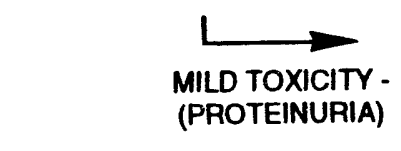

NOTE: NO OBSERVED ADVERSE HEALTH EFFECTS WOULD BE ASSOCIATED WITH POTENTIAL ADULT EXPOSURES.

FIGURE 6.4

HEALTH EFFECTS OF POTENTIAL CADMIUM EXPOSURE FOR ADULTS SHIPROCK, NEW MEXICO, SITE 


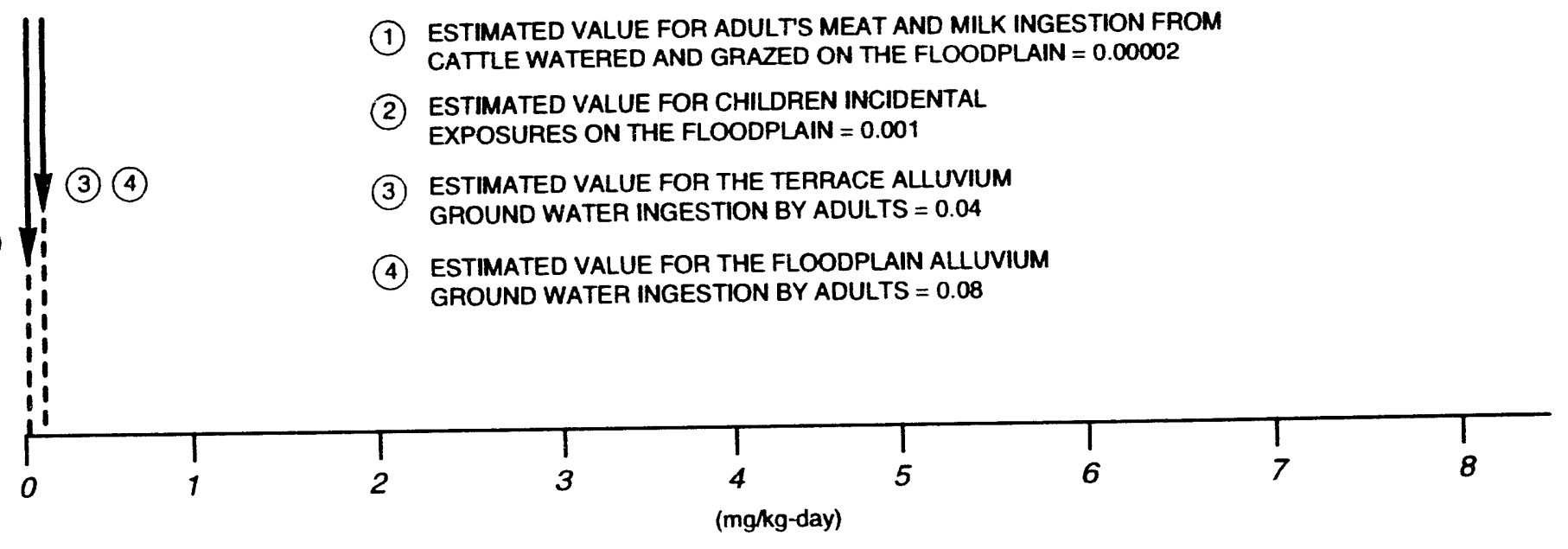

I

DIETARY INTAKE

$\triangle$ ORAL REFERENCE DOSE $(0.003 \mathrm{mg} / \mathrm{kg}$-day)

REVERSIBLE KIDNEY IMPAIRMENT AFTER ACUTE HUMAN EXPOSURE (BASED ON DOSE RECONSTRUCTIN, CASE STUDY)

NO OBSERVED EFFEĆTS IN EITHER MICE OR RATS

(SUFFICIENT HUMAN DATA NOT AVAILABLE)

m.....

MILD TOXICITY

(RABBITS, RENAL DAMAGE)

NOTE: NO OBSERVED ADVERSE HEALTH EFFECTS WOULD BE ASSOCIATED WITH POTENTIAL EXPOSURE TO CHILDREN OR ADULTS.

FIGURE 6.5

HEALTH EFFECTS OF POTENTIAL URANIUM EXPOSURE FOR CHILDREN AND ADULTS SHIPROCK, NEW MEXICO, SITE 


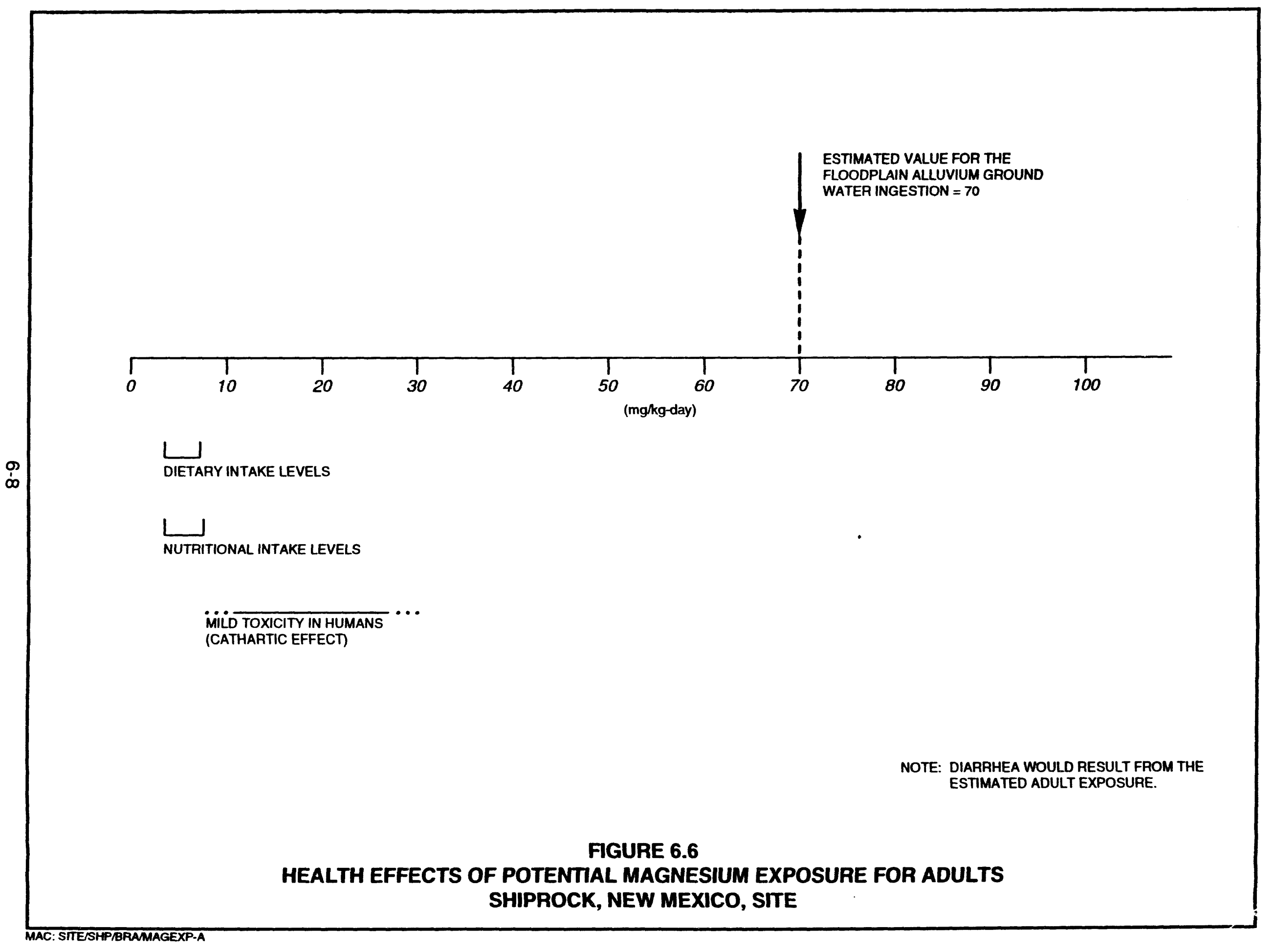




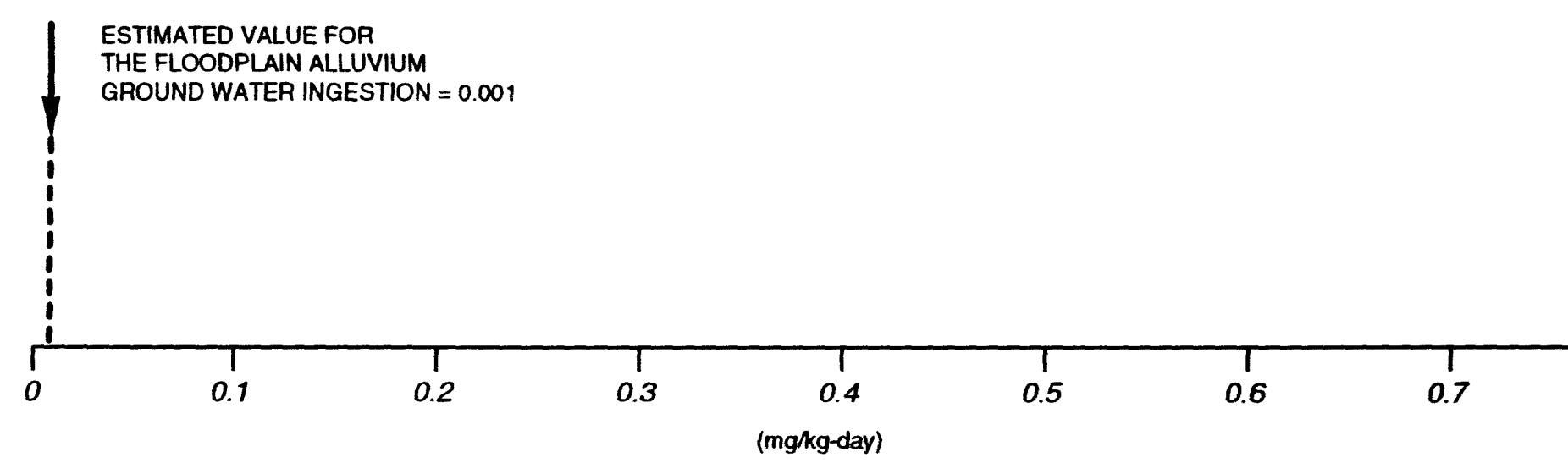

$$
\text { L }
$$

DIETARY INTAKE LEVELS

$\triangle$ oral Reference DOSE $(0.0004 \mathrm{mg} / \mathrm{kg}$-day $)$

$$
\text { MILD TOXICITY IN RATS }
$$

(DECREASED LONGEVITY, ALTERED BLOOD CHEMISTRY

MILD TOXICITY IN HUMANS

(GASTROINTESTINAL DISTRESS AFTER ACUTE EXPOSURE)

NOTE: NO OBSERVED ADVERSE HEALTH EFFECTS WOULD BE ASSOCIATED WITH POTENTIAL ADULT EXPOSURE.

FIGURE 6.7

HEALTH EFFECTS OF POTENTIAL ANTIMONY EXPOSURE FOR ADULTS SHIPROCK, NEW MEXICO, SITE 


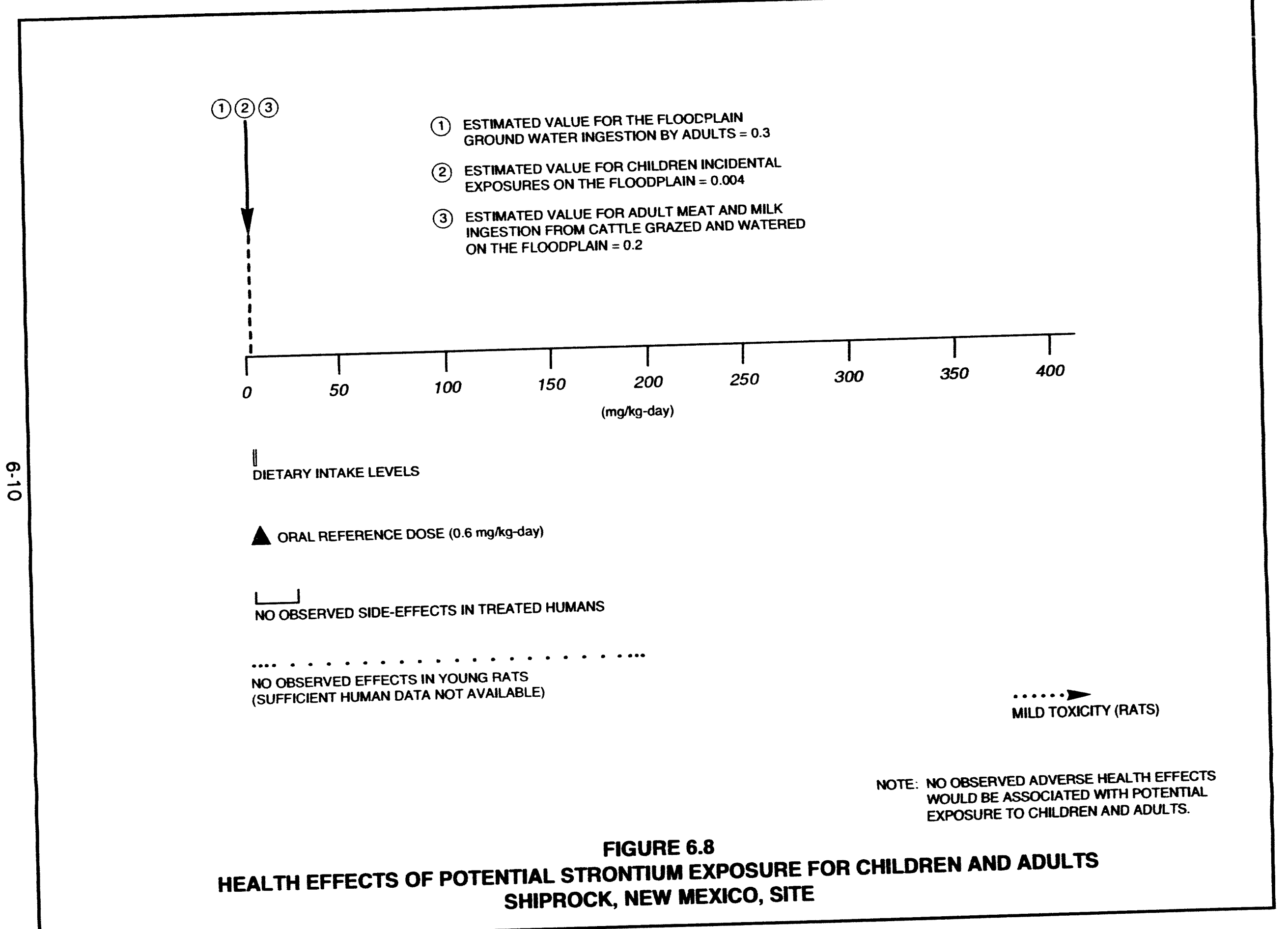




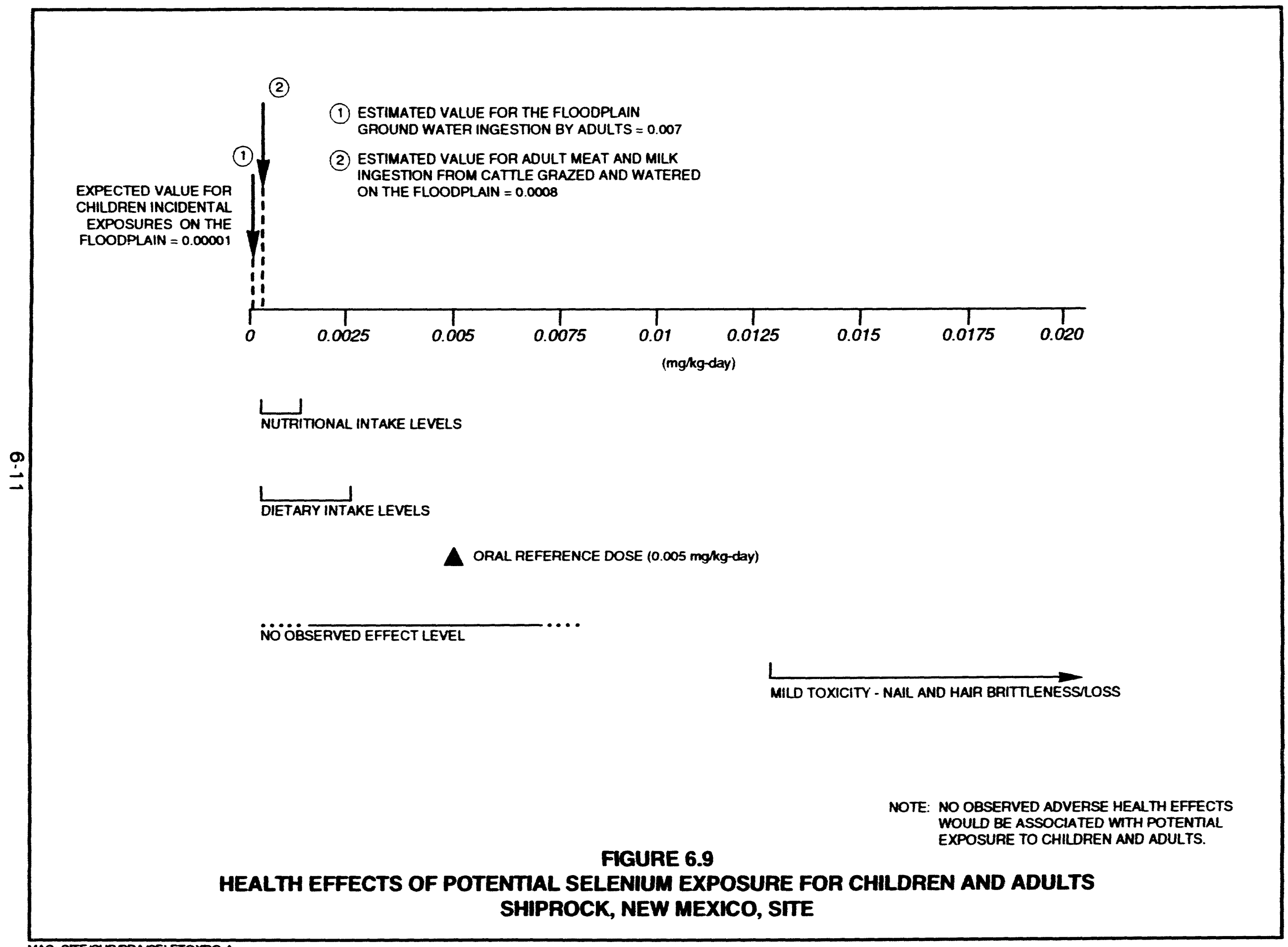




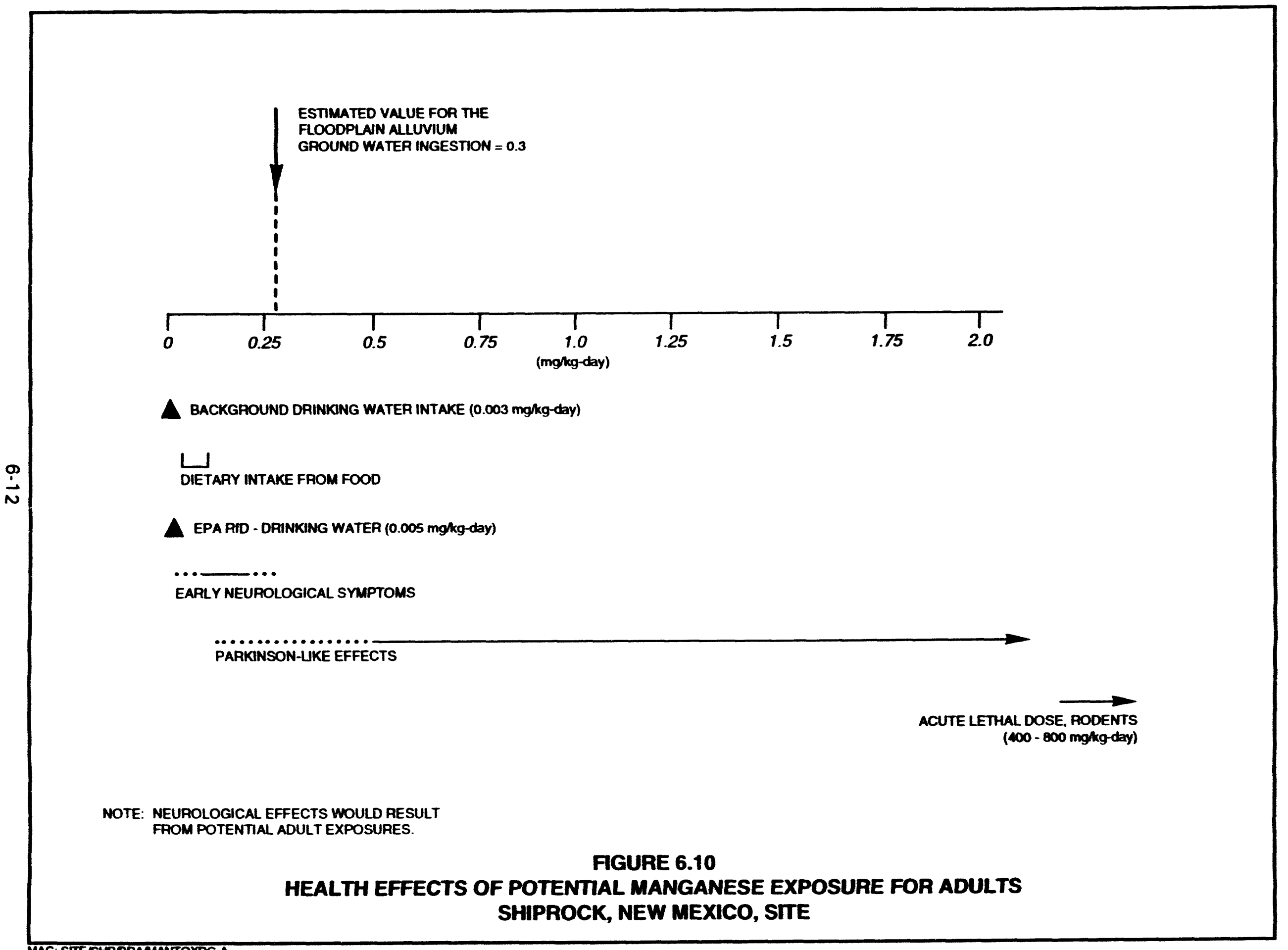




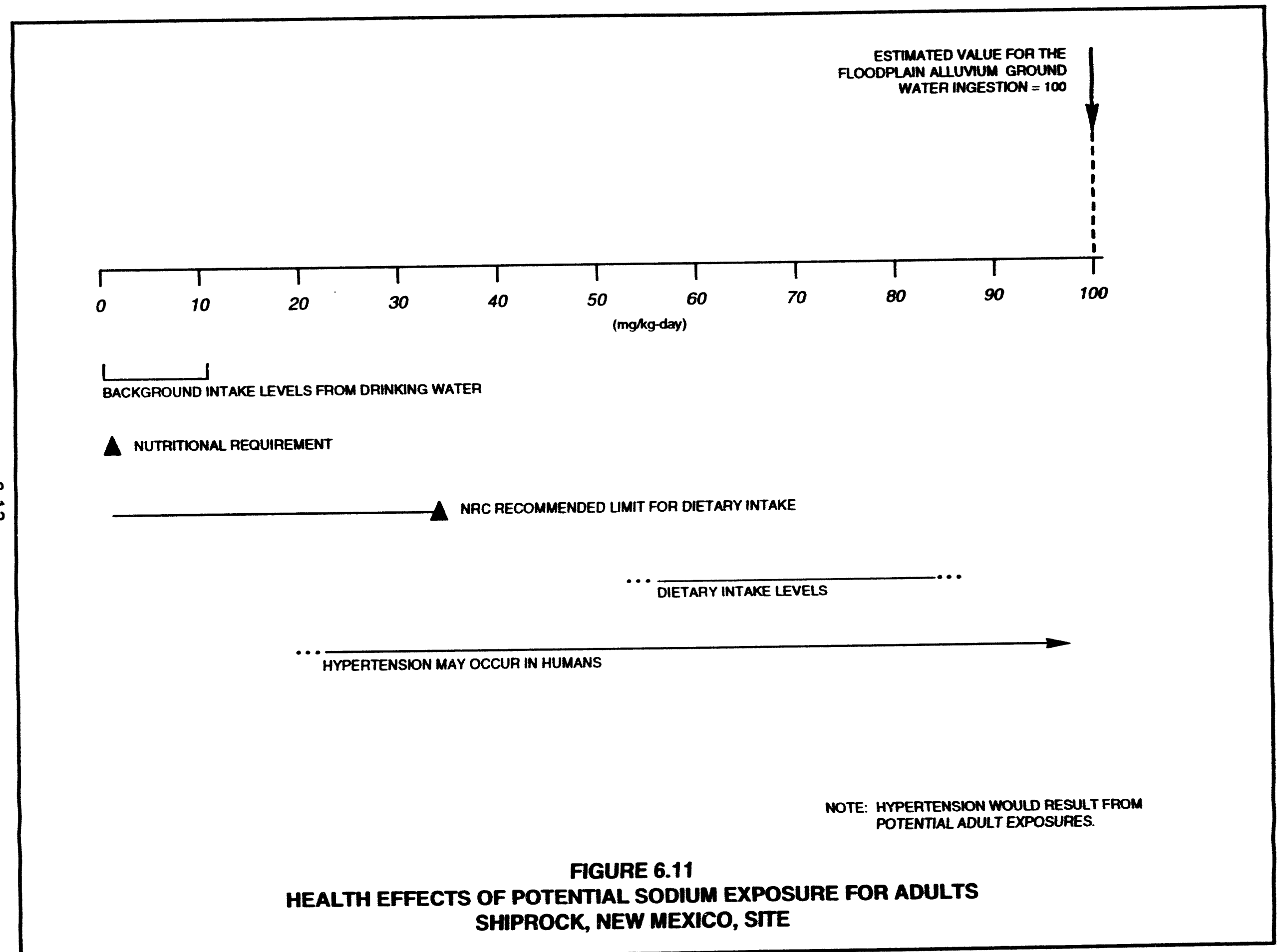




\subsubsection{Terrace alluvium ground water potential use}

The exposure assessment for the terrace alluvium is limited to ground water use as drinking water and considers three contaminants (nitrate, sulfate, and uranium) most likely associated with the former uranium processing site. Exposures to nitrate, sulfate, and uranium are evaluated for their potential to pose adverse health effects in humans exposed by ingesting contaminated ground water. The results of this evaluation are shown in Figures 6.1, 6.2, and 6.5.

As can be seen in Figures 6.1 and 6.2, if the terrace alluvium ground water were used for drinking water, the expected exposure would be 10 times the threshold of the potentially lethal level for infants due to nitrate and sulfate exposures. Uranium exposures do not appear to be associated with adverse health effects in potentially exposed humans; however, as discussed above, this level of exposure in humans has not been adequately studied. Because of these uncertainties in the uranium toxicology data base, these exposure levels are more than 10 times the EPA acceptable intake level (oral RfD).

\subsubsection{Floodplain surface water potential use}

Potential health effects are evaluated for children aged 6 to 12 years who might be exposed to contaminants while playing on the floodplain. Uranium, strontium, and selenium were detected in surface water bodies and sediments at several locations within the floodplain. As can be seen in Figures 6.5, 6.8, and 6.9, no adverse health effects would be expected from incidental exposures (such as incidental ingestion of sediments and surface water or dermal contact with surface water) estimated for this subpopulation.

Likewise, chronic exposure to uranium, strontium, and selenium (Figures 6.5, 6.8, and 6.91 by consuming meat and milk from domestic animals grazed and watered on the floodplain area are not expected to cause adverse health effects in humans.

\subsection{POTENTIAL CARCINOGENIC HEALTH EFFECTS}

If ground water in the floodplain were used as drinking water, skin cancer could develop as a result of chronic exposure to detected arsenic levels (Figure 6.12). This evaluation is based on the EPA oral slope factor of $1.8(\mathrm{mg} / \mathrm{kg} \text {-day) })^{-1}$ for skin cancer development. The potential lifetime excess cancer risk from exposure to arsenic at these levels is estimated at 1 in 1000.

All uranium isotopes are radioactive and, as such, are considered potential carcinogens. The uranium intake and the potential lifetıme carcınogenic risk associated with ingesting ground water from the floodplain is shown in Figure 6.13. The potential lifetime excess cancer risk resulting from this exposure to radioactive uranium would be 1 in 1000. This estimate is based on the cancer slope factor developed by the EPA; however, natural uranium has not been demonstrated to cause cancer in humans or animals following exposure by ingestion. 


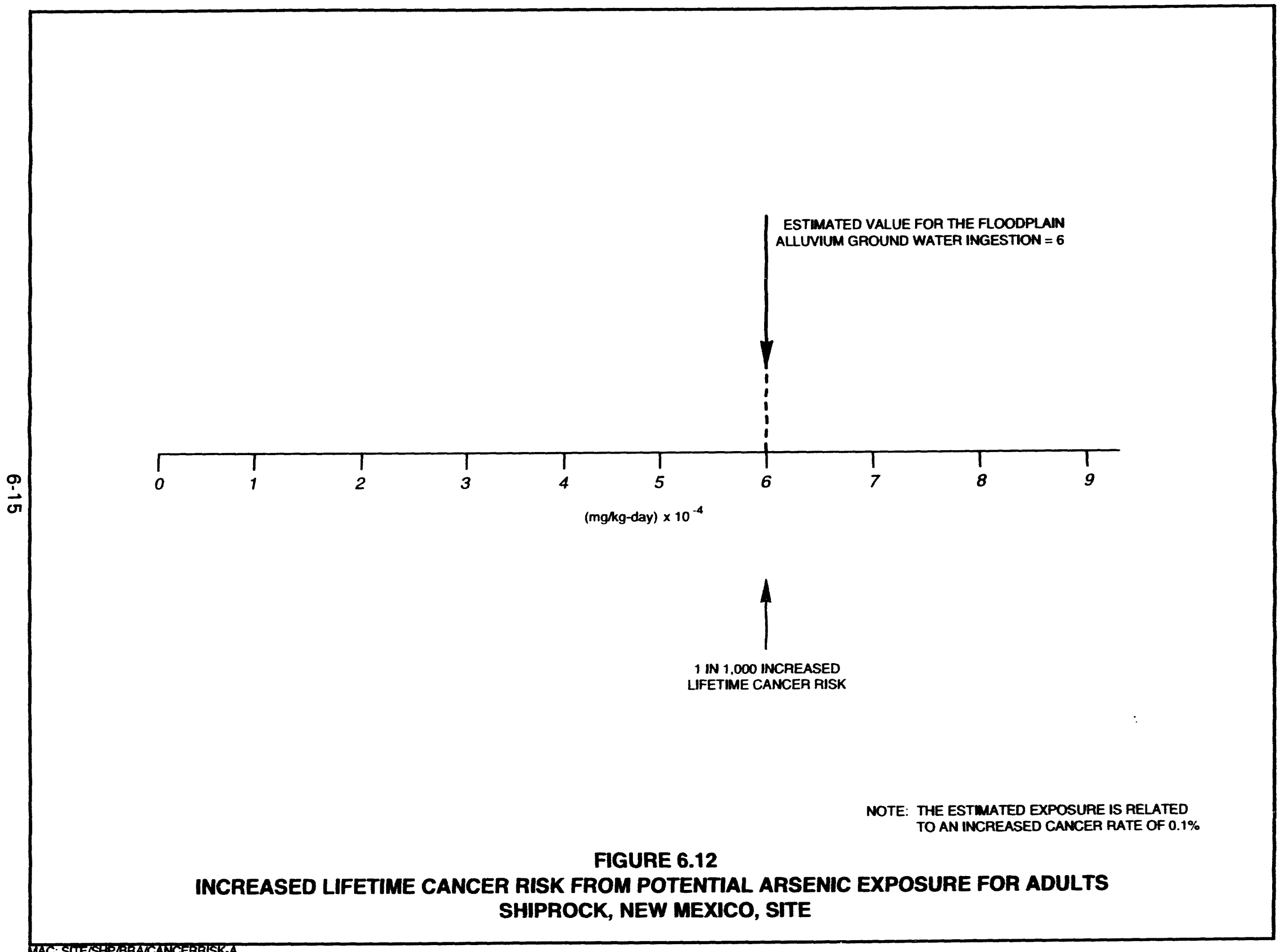




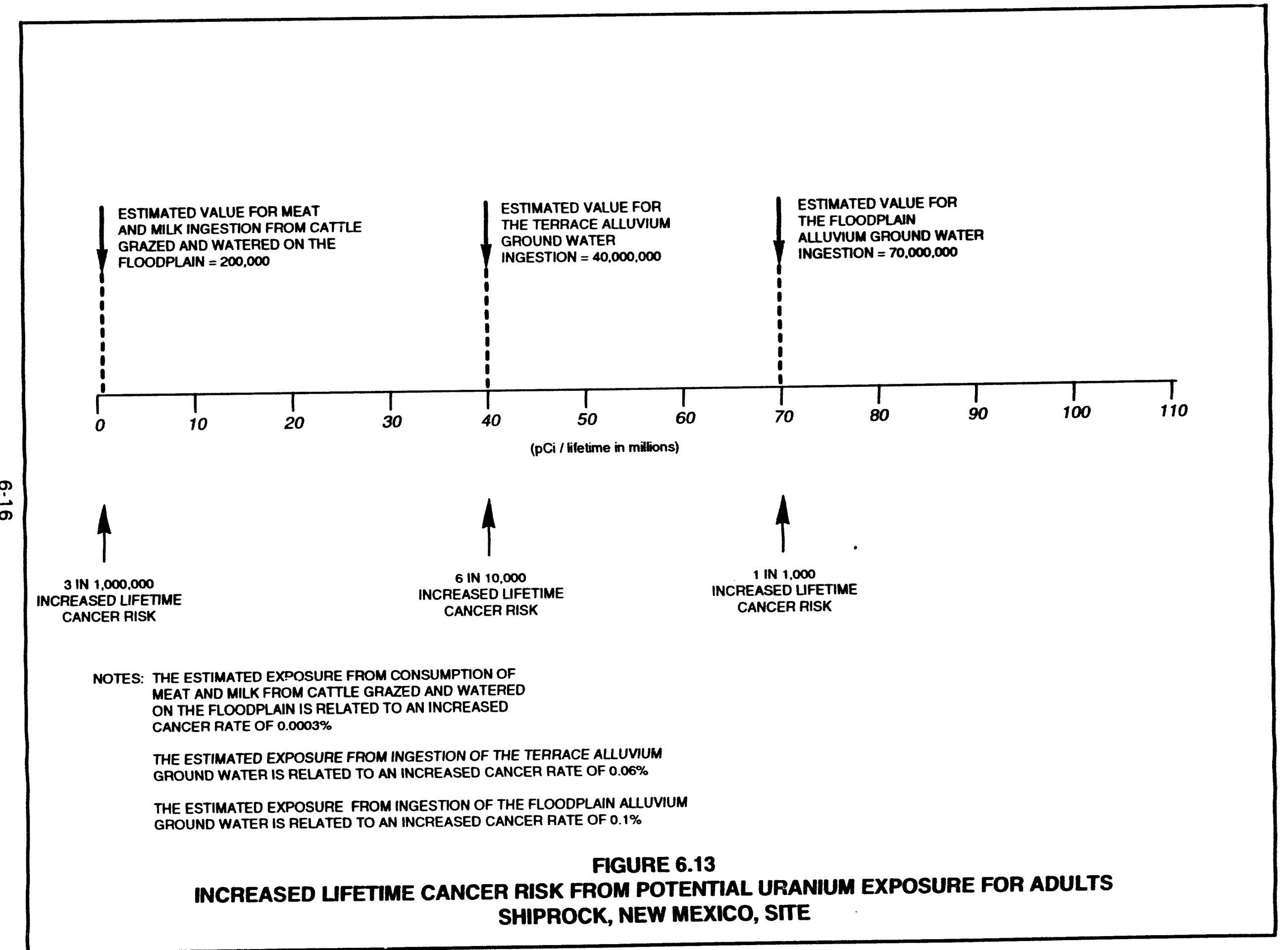


Uranium is the only radionuclide consistently measured above background in the floodplain plume. However, because uranium decays to radioactive progeny, the entire uranium decay series was evaluated for carcinogenic risk. The estimated carcinogenic risk from these radionuclides is shown in Table 6.1.

Carcinogenic risks of ingesting terrace alluvium ground water contaminated with uranium are determined to be 6 in 10,000 excess cancer lifetime risk (Figure 6.13). Radiological risks of ingesting meat and milk from domestic animals grazed and watered on the floodplain area are determined to be 3 in 1 million excess cancer risk per lifetime.

\subsection{LIMITATIONS OF RISK EVALUATION}

The following potential limitations apply to interpretations of this risk evaluation:

- This risk assessment evaluates only risks related to inorganic ground water contamination. Potential contamination with any of the organic constituents used in uranium processing has not been addressed.

- Subpopulations that might have increased sensitivity such as diabetics or the elderly are not specifically addressed on the graphs. Similarly, some individuals may be more sensitive to the toxic effects of certain constituents for reasons that have not been determined.

- Data available to interpret potential adverse health effects are not always sufficient to allow accurate determination of all health effects (i.e., lack of testing in humans or testing of dose ranges other than those expected at this site).

- Although plume movement is evaluated hydrologically and geochemically, the monitoring locations sampled may not be in the most contaminated portion of the plume.

- Only the drinking water exposure pathway was considered in depth, although other pathways were screened to determine their contribution.

The evaluation presented here has considered these limitations and compensated when possible with the use of toxicity ranges rather than point estimates to address some of the variability. The impact of these potential limitations is discussed more fully in Section 8.2 


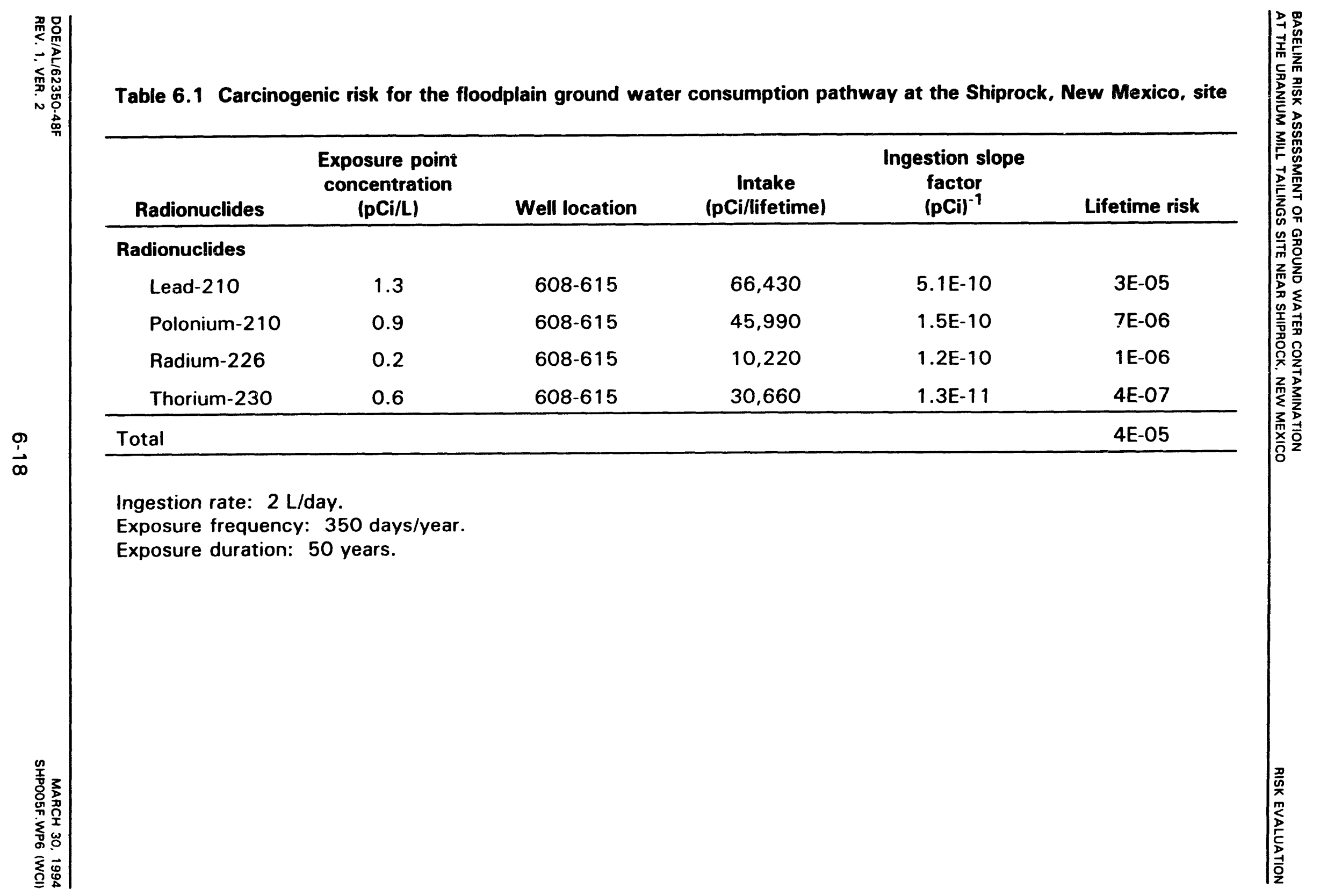




\subsection{LIVESTOCK AND ENVIRONMENTAL EVALUATION}

The objective of the environmental portion of the risk assessment is to determine whether contaminants detected at the site could adversely affect the existing biological community at or surrounding the site. Currently, the EPA has no guidance for quantifying potential impacts to ecological receptors but has developed a qualitative approach generally used for ecological evaluation (EPA, 1989a). With the qualitative approach, the EPA recommends that ambient environmental media concentrations be compared to water quality, sediment quality, or other relevant criteria to determine whether any of the concentrations that the ecological receptors are expected to encounter exceed these criteria. This qualitative approach provides a screening level assessment of the risks associated with potential exposure to contaminated media at the site.

Ecological assessment can be distinguished from human health assessments in that the nature of ecological relationships influences the impacts of constituents. Environmental toxicology, or ecotoxicology, combines the sciences of ecology and toxicology to study the ecological effects of environmental contaminants. Contaminants are defined as environmental constituents that occur at high enough concentrations to cause deleterious biological effects (Moriarty, 1988). Toxicology has focused largely on studying the effects of single compounds on individual organisms. In ecotoxicology, this must be extended to include effects of multiple constituents on the ecosystem. An ecosystem is composed of both abiotic and biological components. The abiotic component is called the habitat. Biological components are organized into species, populations, and communities. A population is composed of individuals of a species that occur within a defined area, and a community is a collection of all populations (plant, animal, bacteria, and fungi) that live in a defined area and interact with one another. In practice, it is not always easy to set the boundaries for populations and communities. The community plus its habitat is an ecosystem (Moriarty, 1988).

Predicting ecotoxicological effects from constituents is extremely complicated. Ecosystems are not static; the biological components experience constant fluctuations in both population numbers and relative composition. Abiotic factors (e.g., temperature, precipitation, nutrient availability) are also constantly changing. The stability of an ecosystem is therefore determined to a great extent by its ability to respond to "normal" stresses. The normal or baseline conditions are not well understood or defined for any ecosystem. Therefore, it is difficult to determine whether changes in ecological parameters (e.g., diversity, total biomass, reproductive trends) are associated with contaminants or merely reflect normal fluctuations.

It is possible that effects on individual organisms or even populations may not affect the ecosystem at all. If a prey species is affected, predators may be able to shift to feeding on other species; predator loss may be compensated for by other predators or by immigration of another predator population. Recognizing when an adverse effect has occurred or is occurring is a challenge. Unless a mass killing occurs within a population or community, ecotoxicological effects may go unnoticed. Sublethal effects such as behavioral changes, reduced reproductive success, enzyme level changes, and effects on microorganisms, can affect independent populations or communities (e.g., reproductive success in one species that may influence another dependent species). Identifying or 
measuring is often difficult. Establishing a causal relationship for a specific environmental stressor, such as a specific contaminant, is accomplished only rarely. Evidence of sublethal effects and gross impacts were not observed during the field survey.

The effects of contaminants on ecological receptors are a concern; however, because scientific understanding of ecosystem interactions is limited, it is difficult to predict whether observed effects on individual populations will result in any real damage to the ecosystem. Because populations are dynamic, establishing the normal range of variability within a population is vital to ecological studies. Sublethal effects, which may be important to overall ecosystem health, are difficult to detect, and contaminants present at low concentrations may not kill organisms directly but may diminish their ability to survive and reproduce.

\subsection{EXPOSURE CHARACTERIZATION}

This section identifies the ecological resources present at the site that are likely to be exposed to site-related contaminants and identifies the possible and probable exposure pathways. For risk to exist, a receptor must be exposed to contaminants. Exposure can occur only if there is both a source of contamination and a mechanism of transport to a receptor population or individual.

The tailings piles and associated contaminated soils have been stabilized permanently in an on-site disposal cell. Thus, direct exposure pathways such as incidental soil ingestion, dermal contact with soil, and inhalation: of particulate-laden air do not represent an ecological concern. However, other direct exposure pathways (e.g., ingestion of surface water potentially affected by contaminated ground water in the floodplain and contaminant bioconcentration in surface water by aquatic organisms) and indirect exposure pathways (bioaccumulation) are possible at the site.

Bioconcentration is the net accumulation of a constituent directly from the surrounding environment. Bioaccumulation is the net accumulation from all routes of exposure, including diet. Generally, bioconcentration is measured for chemical uptake from water by aquatic organisms. Bioconcentration factors (BCF) for soils have been too variable and dependent on site conditions to make identification of generic soil BCFs possible. Fish BCFs in the scientific literature for the contaminants of concern detected in site surface waters range from 1 liter per kilogram (L/ $/ \mathrm{kg})$ for arsenic to $64 \mathrm{~L} / \mathrm{kg}$ for cadmium (EPA, 1992b). No fish BCFs were found in the available literature for the remainder of the contaminants of concern. Significant fish BCF values have ranged from $1000 \mathrm{~L} / \mathrm{kg}$ to $300 \mathrm{~L} / \mathrm{kg}$ (Kenaga, 1980; EPA, 1989a). None of the contaminants of concern detected in site surface waters would be considered significant.

The nearest perennial surface water body to the stabilized tailings pile is the wetlands area on the floodplain at the bottom of Bob Lee Wash. This area receives a constant supply of water from an uncapped artesian well on the terrace that flows down Bob Lee Wash into the wetlands (Figure 2.8). Surface water bodies and associated wetlands occur in Bob Lee Wash and on the floodplain. Water from 
the artesian well on the terrace flows down Bob Lee Wash into an approximately 2-ac (0.8-ha) wetland, then through a ditch and man-made drainage canal to the San Juan River approximately $0.5 \mathrm{mi}(0.8 \mathrm{~km})$ northwest of the disposal cell. The San Juan River forms the eastern and northern boundaries of the floodplain (Figure 2.8). A small area of ponded water (approximately $10 \times 20 \mathrm{ft}[3 \times 6 \mathrm{~m}]$ ) also exists at the base of the escarpment approximately $250 \mathrm{ft}(76 \mathrm{~m})$ east of Bob Lee Wash. This wet area is fed by a seep issuing from a fracture in the bedrock of the escarpment. Several other small areas of standing water were observed in depressions in the floodplain. The water in these depressions was stagnant and may be associated with shallow ground water levels.

These water bodies are all potential exposure points for resident aquatic life and for terrestrial wildlife (including domestic animals) to come in contact with surface water and/or sediments. These exposure pathways were evaluated in this risk assessment.

One potential current pathway is plant uptake of the contaminants in ground water. Due to the shallow depth to ground water, plants can access contaminated ground water. Plant uptake was evaluated in this risk assessment assuming that the plant roots accessed ground water containing the 95 percent upper confidence limit (UCL) concentrations for the contaminants of concern.

For this baseline risk assessment, a future hypothetical exposure pathway also was evaluated. Livestock from several residences located west of Bob Lee Wash could forage and drink water on the floodplain. In the future, if a well were placed in the floodplain plume, contaminated ground water could be used for a livestock watering pond (which could also be stocked with fish) or to irrigate agricultural crops.

\subsection{ECOLOGICAL RECEPTORS}

A qualitative survey of the terrestrial flora and fauna existing in the alluvial floodplain and Bob Lee Wash and the aquatic flora and fauna observed in the surface water bodies on the alluvial floodplain and in Bob Lee Wash was conducted on May 1.9 and 20, 1993.

\subsubsection{Terrestrial flora}

\section{Dense salt cedar habitat}

Very dense, tall (typically 15 to $20 \mathrm{ft}$ [4.5 to $6 \mathrm{~m}$ ) salt cedar grows in bands along the San Juan River. The ground cover is mostly leaves from this species. Within this habitat are scattered Russian olive and patches of Phragmites (common reed). In small open areas, grass is the dominant ground cover, with Bromus sp. the most common species observed. Salt grass is also common.

Dense stands of salt cedar were also observed along the drainage canal that traverses the floodplain. Along the upstream end of the canal, the salt cedars have been burned over in many areas, but most vegetation has recovered, growing to 
heights of 10 to $15 \mathrm{ft}(3$ to $4.6 \mathrm{~m})$. Most areas within the canal contain a fairly dense cattail growth.

\section{Open salt cedar habitat}

Open salt cedar habitat type occurs in the interior of the floodplain back from the river. The salt cedars are 10 to $20 \mathrm{ft}(3$ to $6 \mathrm{~m})$ tall and are scattered approximately 10 to $20 \mathrm{ft}(3$ to $6 \mathrm{~m})$ apart or more. In many areas, salt grass is the dominant ground cover. Within this type are scattered Russian olives, Fremont cottonwoods, black greasewoods, and a few four-winged salt bushes. A few wild privets were also noted.

\section{Disturbed ground habitat}

A large area of disturbed ground that had much less vegetation than the other areas was observed. There was much bare rock (river cobbles), and most of the top soil has been removed. Very widely scattered salt cedars, Russian olives, and weedy annuals such as tumble mustard, Russian thistle, and summer cypress were observed here.

Many low-lying areas within the floodplain have soft saturated soil. Standing water was observed in locations 660 and 661 (Figure 2.8). The areas of saturated soil and standing water did not have a growth of wetland species. Instead, species such as salt cedar and salt grass were the common species in these areas. These areas were wet because the river was very high, resulting in a high water table.

\section{Wetland habitat}

A band of wetlands is present where water from the artesian well (648) enters Bob Lee Wash. This band is 15 to $40 \mathrm{ft}(4.6$ to $12 \mathrm{~m})$ wide and approximately $600 \mathrm{ft}$ $(183 \mathrm{~m})$ long. It consists of a mixture of plant community types. The area is dominated by cattails, salt grass, mixed salt grass and salt cedars, grass, and wild parsnip. The major grass species in this area is manna grass, although other herbaceous grasses and sedges occur. The wetland downstream of the Bob Lee Wash wetlands covers approximately 2 ac $(0.8 \mathrm{ha})$ and contains a mixture of cattails, softstem bulrushes, salt grass, and open water.

\subsubsection{Terrestrial fauna}

Detailed studies regarding wildlife that occur in the Shiprock site area were not conducted. Several bullfrogs were seen throughout Bob Lee Wash and the associated wetland areas. A few garter snakes were also observed near the wetland areas. The only other reptiles observed were whiptails. Some bird species were seen in the floodplain during the field survey, including mourning dove, brownheaded cowbird, red-winged blackbird, meadow lark, Gambel's quail, yellow-billed magpie, yellow warbler, common raven, spotted sandpiper, house finch, mallard, blue-winged teal, black-headed grosbeak, ring-necked pheasant, American gold finch, song sparrow, and killdeer. 
An adult coyote was seen on the hillside leading up to the disposal cell. Tracks of numerous small mammals were seen in the plant communities and disturbed ground on the floodplain. Insects observed included numerous grasshoppers and crickets and ant mounds.

No domestic animals were observed during the field survey. However, livestock from the residences located west of Bob Lee Wash may forage or drink water on the floodplain.

\subsubsection{Aquatic organisms}

A brief qualitative survey of the aquatic organisms in Bob Lee Wash and associated wetlands, the drainage canal, the standing stagnant water, and the pooled water near seep 425 was conducted during the field survey. A fine-mesh dip-net was used to collect fish and benthic macroinvertebrates at these locations.

No observations were made in the San Juan River due to the turbidity, extremely high water level, and rapid velocity of the river.

Other than some mosquito larvae, no aquatic organisms were observed in the two small areas of standing stagnant water (locations 660 and 661). This is not unexpected, considering the ephemeral nature of this standing water.

Visual observations and dip-net collections were made in the wetlands at the mouth of Bob Lee Wash and in the drainage ditch downstream of the wetlands area (locations 658 and 657). The water was clear in the wetlands and ditch. The water depth in the wetlands ranged from less than 1 in $(2.5 \mathrm{~cm})$ along the shoreline to approximately 18 in $(45 \mathrm{~cm})$ in the deeper areas. The water depth in the drainage ditch ranged from approximately 1 to 12 in $(2.5$ to $30 \mathrm{~cm})$. Water did not flow perceptibly in the wetlands area; the water in the ditch flowed slowly. The substrate in the wetlands was composed of fine-grained, brown sand for the first 0.08 to 0.2 in ( 2 to 5 millimeters $(\mathrm{mm}]$ ), and a black, gelatinous muck below the surficial sand. The bottom sediments in the drainage ditch were composed of fineand coarser-grained sands. No floating algae were observed; however, filamentous algae covered a majority of the bottom. Submergent macrophytes were interspersed with the filamentous algae.

A diverse assemblage of aquatic organisms was seen in the wetlands area and the downstream ditch. Water boatmen (Corixidae), backswimmers (Notonectidae), water striders (Gerridae), mosquito larvae, and unidentified cladocerans were observed. Many damselfly (Zygoptera) nymphs were seen, along with a lesser number of dragonfly (Anisoptera) nymphs. A few lace-wing larvae (Chrysopidae) were collected. Snails were seen grazing on periphyton and diving water beetles were common. Chironomid larvae and unidentified nematode worms were found in the bottom sediments. Fish were abundant. They appeared to be of the same type, topminnow, and were identified as Gambusia sp. Young-of-the-year fish were seen among the reeds and cattails in the shallow water areas. A few adult bullfrogs were seen in the wetlands and ditch. Black tadpoles, ranging in size from 
appr sximately 0.2 to 0.4 in $(5$ to $10 \mathrm{~mm})$, were observed in high numbers in the shallow water areas of the ditch downstream of the wetlands. No small tadpoles were observed in the wetlands; a few large brown tadpoles lapproximately 2.5 to 3 in $[63$ to $75 \mathrm{~mm}$ ] long) were observed.

The wetlands area in Bob Lee Wash above the floodplain contained a few areas of ponded water where the flow was slow, but in most of the wash water flowed rapidly over cobbles and rocks until reaching the wetland at the mouth of the wash. The same types of aquatic organisms observed in the wetlands generally were seen in the wash, with one exception. Several case-making caddis fly larvae (Trichoptera) were observed on the undersides of rocks in the flowing portions of the wash. Caddis fly larvae may be collected from virtually all ponds, lakes, and streams, although they are more common in cold, unpolluted water (Bland and Jaques, 1978). No fish were observed. This is not surprising, as it is not likely that fish from the wetlands could migrate upstream against the rapid flow of water.

Turbid water in the drainage canal restricted visual observations and lirnited the effectiveness of dip-net collecting. Most water in the canal probably was backed up from the San Juan River. The bottom sediments were composed of very fine, brownish-black silts and mud 8 to 12 in $(20$ to $30 \mathrm{~cm})$ deep. No emergent or submergent macrophytes were observed, nor were any fish seen or collected. Water striders were seen, and some damselfly nymphs and water beetles were collected.

\subsection{CONTAMINANTS OF ECOLOGICAL CONCERN}

The list of ground water contaminant levels that exceed background (see Table 3.3) was used as the list of contaminants of potential concern in ground water for ecological receptors. Additionally, lead-210, polonium-210, radium-226, and thorium-230 are evaluated.

The list of contaminants of concern in the San Juan River water was developed from the list of contaminants detected above background in ground water isee Table 3.31. This list of contaminants was then compared with the surface water data. When a contaminant was not detected in the river water (e.g., nickel) or the median concentration adjacent to and downstream of the site was less than upstream of the site, it was excluded as a contaminant of potential cuncern for ecological receptors.

The same screening process used to select the contaminants of concern for the San Juan River water was used for the river sediment data.

In summary, after all the ground water constituents exceeding background were examined, the contaminants of concern in the San Juan River are antimony, arsenic, magnesium, sodium, strontium, sulfate, and thorium-230. For the San Juan River sediments, the contaminants of concern remaining after screening are arsenic, manganese, radium-226, strontium, and uranium. 
Surface water and sediments from pools of water on the floodplain were analyzed for the following contaminants of potential concern: manganese, nitrate, selenium, strontium, and uranium.

\subsection{POTENTIAL IMPACTS TO WILDLIFE AND PLANTS}

\subsubsection{Ierrentrial riak}

Terrestrial vegetation was evaluated as a potential exposure pathway. Terrestrial vegetation can be directly exposed to contaminants in ground water through uptake by the roots. Contaminants may accumulate in various plant parts and exert a wide range of influences, depending on the contaminant. Plant uptake rates vary greatly among species and are affected by factors such as soil characteristics (e.g., pH, moisture, redox potential, organic matter), plant sensitivity, input-output balance, or cumulative effects. Foraging wildlife can be exposed indirectly to contaminants in ground water by ingesting plants that have bioaccumulated certain contaminants. Based on the shallow depth to contaminated ground water at the site, it is possible that some plants could root in soils that intercept contaminated ground water.

Terrestrial wildlife can be exposed directly to contaminants in site surface water bodies by ingesting the surface water, aquatic organisms, and sediments. However, good information on generic BCFs for terrestrial wildlife is not available in the scientific literature.

Concentrations of the contaminants of potential concern in plant tissue were estimated using soil-to-plant BCFs. No soil data are available for the site, nor are water-to-plant BCFs. However, because plant nutrients must be in an aqueous form for root uptake, it was considered appropriate to use the soil-to-plant BCFs for estımating potential plant uptake at the site. Soil concentrations in the saturated zone were estimated by multiplying the ground water concentration by the soiiwater distribution coefficient, $\mathrm{Kd}$. The parameters used to estimate root uptake and plant tissue concentrations for the contaminants of concern are presented in Table 7.1. The methodology is described in ORNL (1984).

The estimated tissue concentrations for the contaminants of potential concern in the vegetative portions (e.g., stems, leaves) and in the nonvegetative portions (e.g., fruits, tubers) were compared to approximate concentrations in mature leaf tissue that have been reported to be toxic to plants (phytotoxic) (Table 7.1). The phytotoxic concentrations reported in Table 7.1 are not representative of very sensitive or highly tolerant plant species. The estimated tissue concentrations for the contaminants of concern in the plants on the floodplain do not exceed the available phytotoxicity data. However, no comparison data were available for calcium, chloride, lead-210, magnesium, nitrate, potassium, polonium-210, radium-226, strontium, sodium, sulfate, thorium-230, and uranium. Thus, it is not possible, with existing data, to evaluate whether the estimated tissue concentrations could result in adverse effects to plants. 


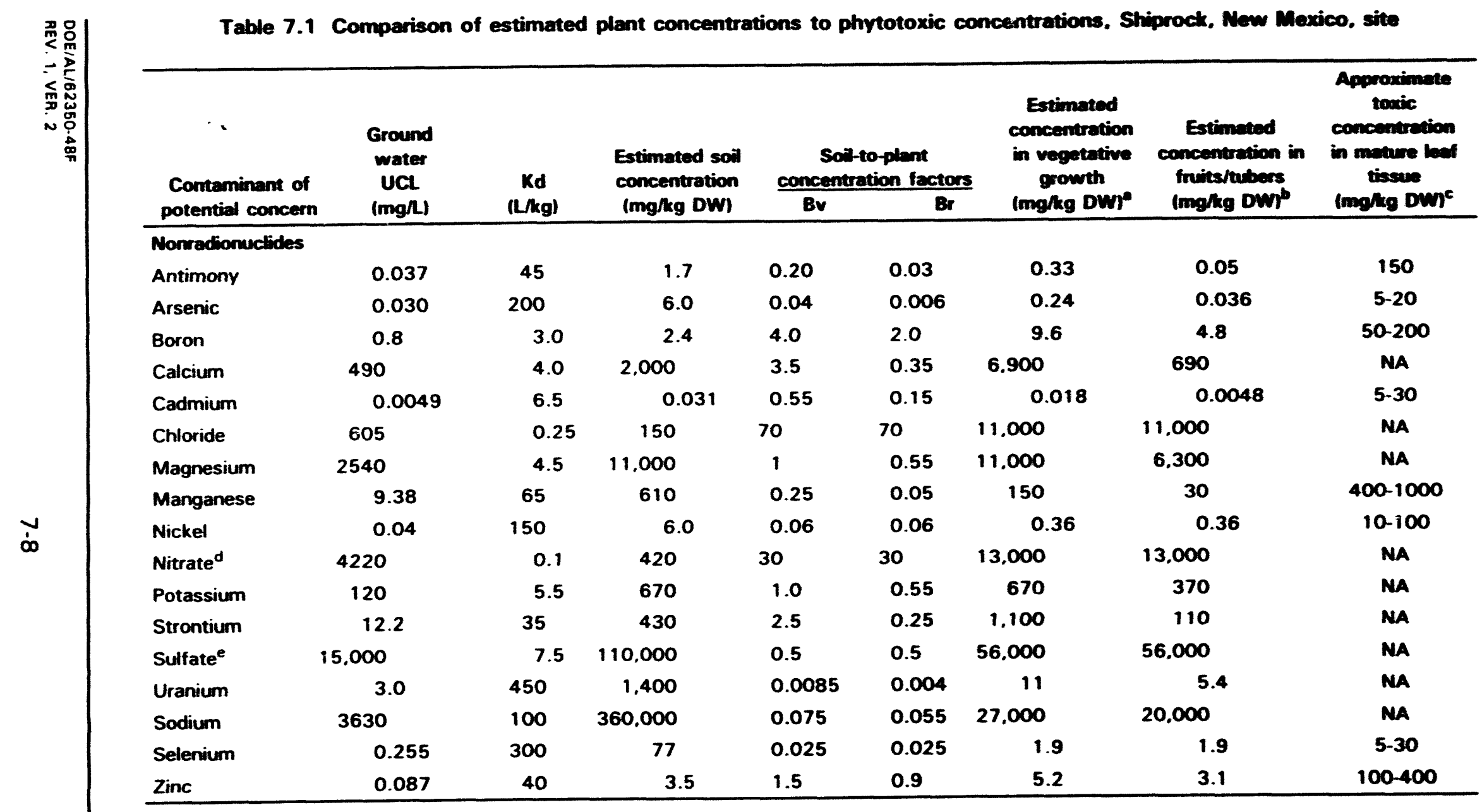




\begin{tabular}{|c|c|c|c|c|c|c|c|c|}
\hline $\begin{array}{l}\text { Contaminant of } \\
\text { potential concern }\end{array}$ & $\begin{array}{l}\text { Ground } \\
\text { water } \\
\text { UCL } \\
\text { (mg/L) }\end{array}$ & $\begin{array}{c}\text { Kd } \\
\text { (L/kg) }\end{array}$ & $\begin{array}{l}\text { Estimated soil } \\
\text { concentration } \\
\text { (mg/kg DW) }\end{array}$ & $\frac{\begin{array}{r}\text { Soil- } \\
\text { concentr }\end{array}}{\mathrm{Bv}}$ & $\frac{\text { olan factors }}{B r}$ & $\begin{array}{l}\text { Estimated } \\
\text { concentration } \\
\text { in vegetative } \\
\text { growth } \\
\text { (mglkg DWre }\end{array}$ & $\begin{array}{l}\text { Estimated } \\
\text { concentration in } \\
\text { fruits/tubers } \\
\text { (mo/kg DWI }\end{array}$ & $\begin{array}{l}\text { Approximate } \\
\text { toxic } \\
\text { concenteration } \\
\text { in mature beaf } \\
\text { tissue } \\
\text { Imghing DWn }\end{array}$ \\
\hline \multicolumn{9}{|l|}{ Radionuclides } \\
\hline Lead-210 & $2.9 \mathrm{E}-13$ & 900 & $2.6 E-10$ & 0.045 & 0.009 & $1.2 E-11$ & $2.3 E-12$ & NA \\
\hline Polonium-210 & 1.7E-11 & 500 & $8.5 E-9$ & 0.0025 & 0.0004 & $2.1 E-11$ & $3.4 E-12$ & NA \\
\hline Radium-226 & $2.0 E-10$ & 450 & $9.0 E-8$ & 0.015 & 0.0015 & $1.4 E-9$ & $1.4 E-10$ & NA \\
\hline Thorium-230 & $3.0 E-8$ & 150.000 & $4.5 \mathrm{E}-3$ & 0.00085 & 0.000085 & $3.8 E-6$ & $3.8 \mathrm{E}-7$ & NA \\
\hline
\end{tabular}

${ }^{a}$ Estimated concentration in vegetative portions, calculated as estimated soil concentration multiplied by Bv.

bstimated concentration in nonvegetative portions, calculated as estimated soil concentration multiplied by Br.

${ }^{c}$ Concentrations are not presented for very sensitive or for highly tolerant plant species (Kabata-Pendias and Pendias, 1992).

${ }^{\mathrm{d}} \mathrm{Bv}$ and $\mathrm{Br}$ factors available for elemental nitrogen only. It is expected that the $\mathrm{Bv}$ and $\mathrm{Br}$ factors for nitrate would be higher than for nitrogen.

${ }^{\mathrm{E}} \mathrm{Bv}$ and $\mathrm{Br}$ factors available for elemental sulfur only; thus, these factors were reduced by a factor of 3 for sulfate

Kd - soil-water distribution coefficient (ORNL, 1984).

Bv - soil-to-plant elemental transfer factor for vegetative portions of food crops and feed plants (ORNL. 1984).

$\mathrm{Br}$ - soil-to-plant elemental transfer factor for nonvegetative portions (e.g., fruits, tubers) of food crops and feed plants (ORNL. 1984).

DW - dry weight.

mg/kg - milligrams per kilogram.

mg/L - milligrams per liter.

L/kg - liters per kilogram.

UCL - upper 95 percent one-tailed confidence interval of the median.

$\mathrm{No} \mathrm{Kd}, \mathrm{Bv}$, or $\mathrm{Br}$ values available for ammonium and phosphate.

NA - not available. 
Bioaccumulation in terrestrial organisms as a function of contaminants of concern in ingested plants or animals (e.g., birds eating aquatic macroinvertebrates) is a potential exposure pathway at the site. Birds and other vertebrates consuming these plants and animals can bioaccumulate some of the contaminants of concern from this diet if the amount ingested exceeds the amount eliminated. This is often a function of the areal extent of contamination compared to the areal extent of the animals' feeding range. In the case of small contaminated areas, the amount of food in the diet usually exceeds the impacted food and bioaccumulation is not a concern. Therefore, exposure via the diet for all trophic level species is possible in certain areas (e.g., wetland areas) but the potential for bioaccumulation is not always a concern.

Biomagnification is a more severe situation in which the concentration of a constituent increases in higher levels of the food chain because the contaminant concentrations accumulate through each successive trophic level. Biomagnification effects are of particular concern for top predators, especially carnivorous birds and mammals. Only a limited number of constituents have the potential to magnify in the food chain. Most constituents are metabolized in organisms and eliminated at each level of the food chain.

Based on available information, the potential for the detected contaminants of concern to represent a health hazard via food chain transfer is probably low. However, no sampling of plant or animal tissue has been conducted to date as part of the site characterization and it is not possible to definitively determine the bioaccumulation or biomagnification of site-related contaminants of concern.

To evaluate the future hypothetical impact that use of contaminated ground water in a livestock pond might have on wildlife li.e., animals drinking from the pond or fish stocked in the pond), the 95 percent $U \mathrm{CL}$ ground water concentrations for the contaminants of concern are compared to available comparison water quality criteria (Table 7.2). No available federal or state criteria or standards exist to protect terrestrial wildlife via water exposure. Therefore, it is difficult to evaluate the potential hazards to terrestrial receptors without additional information. Available surface water quality criteria for the protection of freshwater aquatic life. however, do exist and include the Federal Water Quality Criteria (FWQC) (EPA, 1986).

The 95 percent UCL ground water concentrations for antimony, chloride, manganese, nitrate, and selenium exceeded the comparison water quality criteria (Table 7.2), while the ground water concentrations for arsenic, cadmium, nickel, and zinc were below the comparison aquatic criteria. The 95 percent UCL for antimony, chloride, and selenium exceed the chronic FWOC, indicating this water would be unacceptable for aquatic organisms. No comparison water quality criteria are available for ammonium, boron, calcium, lead-210, magnesium, potassium, phosphate, radium-226, sodium, strontium, sulfate, thorium-230, and uranium.

Another future hypothetical use of the ground water in the area is for irrigating agricultural crops. Table 7.2 shows the approximate concentrations in water used 
Table 7.2 Comparison of contaminants of concern in ground water with avallable water quality criteria, Shiprock, Now Mexico, site

\begin{tabular}{|c|c|c|c|c|}
\hline $\begin{array}{l}\text { Contaminant of } \\
\text { potential concern }\end{array}$ & $\begin{array}{c}\text { Ground water } \\
\text { UCL }\end{array}$ & FWac & $\begin{array}{c}\text { Water } \\
\text { concentration } \\
\text { protective of } \\
\text { liveatock }\end{array}$ & $\begin{array}{c}\text { Concentration } \\
\text { in irrigation } \\
\text { water } \\
\text { protective of plants" }\end{array}$ \\
\hline Ammonium & 516 & NA & NA & NA \\
\hline Antimony & 0.037 & $0.030(\mathrm{Sn}$ III) & NA & NA \\
\hline Arsenic & 0.030 & 0.19 (As III) & 0.20 & 0.10 \\
\hline Boron & 0.8 & NA & 5.0 & 0.75 \\
\hline Calcium & 490 & NA & NA & NA \\
\hline Cadmium & 0.0049 & $0.048^{b}$ & 0.050 & 0.010 \\
\hline Chloride & 605 & 230 & NA & NA \\
\hline Lead-210 & $0.9 \mathrm{pCi} / \mathrm{L}$ & NA & NA & NA \\
\hline Magnesium & 2540 & NA & NA & NA \\
\hline Manganese & 9.38 & $1.5^{\mathrm{c}}$ & NA & 0.20 \\
\hline Nickel & 0.04 & $8.9^{b}$ & NA & 0.20 \\
\hline Nitrate & 4220 & $90^{d}$ & 100 & NA \\
\hline Polonium-210 & $1.3 \mathrm{pCi} / \mathrm{L}$ & NA & NA & NA \\
\hline Potassium & 120 & NA & NA & NA \\
\hline Phosphate & 0.1 & NA & NA & NA \\
\hline Radium-226 & $0.2 \mathrm{pCi} / \mathrm{L}$ & NA & NA & NA \\
\hline Selenium & 0.255 & 0.035 & 0.050 & 0.020 \\
\hline Sodium & 3630 & NA & NA & NA \\
\hline Strontium & 12.2 & NA & NA & NA \\
\hline Sulfate & 15,000 & NA & 1000 & NA \\
\hline Thorium-230 & $0.6 \mathrm{pCi} / \mathrm{L}$ & NA & NA & NA \\
\hline Uranium & 3.0 & NA & NA & NA \\
\hline Zinc & 0.087 & $6.0^{b}$ & 25 & 2.0 \\
\hline
\end{tabular}

From EPA (1972), unless specified otherwise.

bWater hardness-related chronic FWOC (EPA, 1986). Criterion presented was calculated using the average hardness $(11,710 \mathrm{mg} / \mathrm{L})$ determined from concentrations of calcium and magnesium in alluvial aquifer wells.

${ }^{C}$ No FWQC available. Value presented is the lower end of the tolerance range for freshwater aquatic life (EPA, 1986).

dConcentration at or below which no adverse effects are expected for warm water fish (EPA, 1986).

All concentrations reported in milligrams per liter, unless specified otherwise.

UCL - upper 95 percent one-tailed confidence interval of the median.

FWOC - FWOC for the protection of freshwater aquatic life via chronic exposure (EPA 1986), unless specified otherwise.

NA - not available. 
for irrigation that should be protective of plants (EPA, 1972). Seven of the contaminants of potential concern (arsenic, boron, cadmium, manganese, nickel, selenium, and zinc) have comparison criteria. The 95 percent UCL ground water concentrations for boron, manganese, and selenium exceed the comparison criteria, while the concentrations of arsenic, cadmium, nickel, and zinc are below the comparıson criteria. No comparison criteria are available for the remaining contaminants of potential concern.

Other basic criteria required to evaluate the suitability of water quality for irrigation, in addition to the concentrations of metals that may be toxic to plants, are the total soluble salt content and the sodium hazard. Excess salt in water increases the osmotic pressure of the soil solution. This increase can elicit a physiological drought condition in the plants. The total soluble salt content of water can be measured by the specific conductance (electrical conductivity). The 95 percent $\mathrm{UCL}$ for specific conductance from a representative plume well (well 615) is 16,600 micromhos per centimeter $(\mu \mathrm{mhos} / \mathrm{cm})$. This value is well above the upper end of the acceptable range for salt-tolerant plants, $7500 \mu \mathrm{mhos} / \mathrm{cm}$ (Follett and Soltanpour, 1985). Sodium concentrations can contribute to the total salinity of an irrigation water and may be directly toxic to sensitive crops. However, the primary concern with elevated sodium concentrations is the adverse effect on the physical characteristics of soils le.g., increase in colloidally absorbed sodium, resulting in hard compact soill. The sodium hazard of water is expressed as the sodium adsorption ratio (SAR), which is calculated as the proportion of sodium to calcium plus magnesium in the water. Using the 95 percent $U C L$ ground water concentrations for sodium, calcium, and magnesium, a SAR of 14.6 was calculated. This SAR is above the upper SAR limit of 10 (Follett and Soltanpour, 1985). Water with a SAR value greater than 10 should not be used as the sole source of irrigation water for long periods of time.

Based on available information, using the alluvial ground water (containing the upper 95 percent UCL concentrations) as irrigation water would result in deleterious effects to plants, primarily because of elevated concentrations of boron, manganese, and selenium and because of the salinity and sodium hazard.

\subsubsection{Aquatic risk}

\section{Bob Lee Wash and associated wetlands}

Surface water (unfiltered) and surficial sediment 10 to 4 in 10 to $10 \mathrm{~cm}$ ) were collected from Bob Lee Wash above the floodplain (location 662) and from the wetlands on the floodplain (locations 658 and 657) (Figure 2.8) on May 19 and 20, 1993. The surface water samples were analyzed for manganese, nitrate, selenium, strontium, and uranium. The sediment samples were analyzed for manganese, selenium, strontium, and uranium. In addition, unfiltered surface water samples were collected from the channel created by the water flowing from the artesian well (location 648) above the floodplain. One sample was collected immediately below the well (location 761) and the other was collected from the channel just before it empties into Bob Lee Wash (location 762). The samples were analyzed for 
alkalinity, ammonium, antimony, arsenic, cadmium, calcium, chloride, chromium, cobalt, copper, iron, lead, lead-210, manganese, molybdenum, nitrate, pH, phosphate, polonium-210, radium-226, selenium, sodium, specific conductance, strontium, sulfate, temperature, thorium-230, total dissolved solids, total organic carbon, uranium, vanadium, and zinc.

The surface water concentrations for the analyzed constituents were very similar among the sampling locations and compared with concentrations detected in the artesian well ground water (Table 7.3). This similarity is expected, considering the constant input of artesian well water to these areas.

The detected concentrations relative to available comparison water quality criteria show that none of the constituents were detected at concentrations above the comparison criteria. Selenium was not detected in the surface water collected from Bob Lee Wash and the wetlands.

There are no sediment quality criteria or background sediment quality data for the floodplain with which to compare the detected concentrations. In general, the concentrations were similar among locations, although the highest concentrations of strontium and uranium were detected in the large wetlands at the mouth of Bob Lee Wash (Table 7.4). No information was found in the available literature on the potential for these concentrations to represent a hazard to ecological receptors, but additional research is recommended.

Based on this qualitative evaluation and the diversity of organisms observed in Bob Lee Wash and the wetlands, the concentrations detected in surface water and sediments apparently do not affect the ecosystem adversely. However, additional fieldwork and quantitative analyses are required to fully evaluate the biological integrity of this ecosystem.

\section{Drainage canal}

Surface water (unfiltered) and surficial sediment samples were also collected during the field survey from two locations (locations 655 and 656) in the drainage canal that traverses the floodplain. The results are presented in Tables 7.3 (surface water) and 7.4 (sediment). The detected surface water concentrations for each contaminant of concern were generally similar, although selenium was reported at the detection limit at location 655. The detected concentrations for all contaminants of potential concern were below available comparison water quality criteria.

The sediment concentration of selenium was highest in the canal at the location near the confluence with the San Juan River (location 655), while concentrations of the other contaminants of potential concern were highest at the upstream location (656) in the drainage canal. As discussed earlier, no sediment quality criteria or background data are available for comparison with the canal data. Observations of aquatic life in the canal were hampered by the turbid water and lack of substrate (e.g., aquatic macrophytes, rock/cobble). 


10
10

aNo FWOC available. Value presented represents lower end of tolerance range for freshwater aquatic life (EPA, 1986).

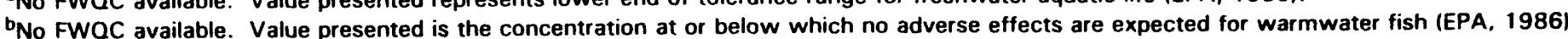

All concentrations reported in milligrams per liter in total (unfiltered) samples.

NA - not available.

FWQC - FWOC for the protection of freshwater aquatic life via chronic exposure (EPA, 1986), unless specified otherwise. 
Table 7.4 Contaminants of concern detected in sediment from site surface water bodies, Shiprock, New Mexico, site

\begin{tabular}{|c|c|c|c|c|c|c|c|c|}
\hline \multirow{2}{*}{$\begin{array}{l}\text { Contaminant of } \\
\text { potential concern }\end{array}$} & \multicolumn{3}{|c|}{ Bob Lee Wash and associated wetlands } & \multicolumn{2}{|c|}{$\frac{\text { Drainage canal }}{\text { Location ID }}$} & \multicolumn{2}{|c|}{$\frac{\text { Stagnant pools }}{\text { Location ID }}$} & \multirow{2}{*}{$\begin{array}{c}\text { Wet area below } \\
\text { seep } 425 \\
\begin{array}{c}\text { Location ID } \\
659\end{array}\end{array}$} \\
\hline & 657 & 658 & 662 & 655 & 656 & 660 & 661 & \\
\hline Manganese & 162 & 179 & 533 & 360 & 1050 & 654 & 312 & 184 \\
\hline Selenium & 1.2 & $<1.7$ & $<0.9$ & 5.0 & $<1.0$ & $<0.8$ & $<3.0$ & 4.2 \\
\hline Strontium & 188 & 448 & 232 & 157 & 185 & 698 & 128 & 1620 \\
\hline Uranium & 2.6 & 4.7 & 3.8 & 3.3 & 5.8 & 22 & 5.9 & 44 \\
\hline
\end{tabular}

$\stackrel{v}{v}$

All concentrations reported in milligrams per kilogram. 


\section{Stagnant pools}

Two small pools of standing stagnant water on the floodplain were sampled during the field survey (locations 660 and 661) (Figure 2.8). The unfiltered surface water concentrations of manganese and uranium detected at location 660 were the highest detected in any floodplain surface water bodies. This stagnant pool of water was located midway between monitor well 616 and the San Juan River. No selenium was detected (Table 7.3). As in Bob Lee Wash and the drainage canal, none of the contaminants of potential concern were detected at concentrations above the comparison water quality criteria (Table 7.3). However, the maximum uranium concentration of $1.1 \mathrm{mg} / \mathrm{L}$ detected at location 660 is more than 1 order of magnitude higher than concentrations detected in the San Juan River, the drainage canal, Bob Lee Wash, and the associated wetlands. It is not known whether this concentration represents a hazard to aquatic life. As mentioned earlier, these small pools of standing water are ephemeral and probably were associated with the high water table that occurred during the field survey.

The concentrations detected in sediments from these pools were similar to concentrations detected in the drainage canal, with the exception of the elevated concentrations of strontium $(698 \mathrm{mg} / \mathrm{kg})$ and uranium $(22 \mathrm{mg} / \mathrm{kg})$ at location 660 .

\section{Wet area near seep 425}

Unfiltered surface water and sediment samples were collected from the ponded water at the base of the escarpment directly below seep 425 . The primary source of water for this ponded water is probably discharge from the seep. A review of the surface water data seems to support this. The highest concentrations for nitrate and selenium anywhere on the floodplain were detected in this water (Table 7.3). The reported nitrate concentration exceeds the comparison water quality criteria and the selenium concentration equals the FWOC. Concentrations this high could adversely affect aquatic life.

The sediment concentrations of strontium $(1620 \mathrm{mg} / \mathrm{kg})$ and uranium $(44 \mathrm{mg} / \mathrm{kg})$ were the highest detected in any floodplain surface water body. This is probably a reflection of the seep water input. It is not known if the fish observed in this ponded water are year-round residents or whether they migrated from the Bol Lee Wash wetlands area during high water and then were trapped as the water receded.

\section{San Juan River water}

Another potential exposure point is the San Juan River in the vicinity of the site along the alluvial floodplain. As described in Section 2.4, the plume of contaminated alluvial ground water is believed to be discharging to the river. Also, contaminants in a dissolved state or associated with particulates may have been transported from the site to the floodplain and to the river via overland surface runoff. Another potential release mechanism involves expression of contaminated ground water to a floodplain surface water body that intersects the water table 
(e.g., the drainage canal). Thus, historical surface water data collected from the San Juan River at locations upstream (locations 546 and 554 pooled together) were compared with locations adjacent to and downstream llocations 548 through 553 and 555 pooled together) of the site. Unfiltered data were collected from the river in 1993 and filtered data were collected from 1987 to 1989.

A review of surface water data indicates that thorium-230 was not detected upstream of the site; however, the median concentration detected adjacent to and downstream of the site was less than the detection limit. The median concentrations for antimony, arsenic, magnesium, sodium, strontium, and sulfate at the locations adjacent to and downstream of the site were higher than at the upstream locations. However, the median concentrations for each contaminant of potential concern were within the same order of magnitude and the differences between the upstream and downstream concentrations ranged from approximately 9 to 39 percent. Although these data suggest a relationship with the site, they do not provide compelling evidence that site-related contamination has affected the water quality of the San Juan River. For this risk assessment, the median concentrations for the contaminants of concern were compared to available comparison water quality criteria. These comparison criteria are FWOC for the protection of freshwater aquatic life via chronic exposure (EPA, 1986; 1988b).

A comparison of the historical surface water quality data with available water quality criteria indicates that none of the concentrations exceed their respective comparison criteria upstream or downstream of the site (Table 7.5). Water quality criteria for aquatic life are not available for magnesium, sodium, strontium, sulfate, and thorium-230. Considering there is essentially no difference between the upstream and downstream median concentrations for these metals, these concentrations are unlikely to represent an ecological concern, nor can they be attributed to impacted ground water from the floodplain. However, continued monitoring of the river is recommended.

\section{San Juan River sediments}

There are no established tribal, state, or federal sediment quality criteria $(S Q C)$ for the protection of aquatic life, although the EPA has presented interim SOCs for several nonpolar hydrophobic organic compounds (EPA, 1988c). However, no organic compounds were measured at this site.

The EPA is evaluating a methodology based on the three-phase sorption model for free metal ion activity and is assessing its applicability for determining the bioavailable fraction within sediments (EPA, 1989b). Several other predictive models and methods are being investigated for metals but no one approach has been accepted to adequately develop sediment-based metals criteria (Shea, 1988; Chapman, 1989; EPA, 1989b; NOAA, 1990; Di Toro et al., 1991; Burton, 1991). Therefore, only a qualitative hazard assessment of the metals detected in sediments are presented in this risk assessment. 
Table 7.5 Comparison of contaminante of concern in San Juan River water with available water quality criteria, Shiprock, New Mexico, site

\begin{tabular}{|c|c|c|c|}
\hline \multirow[b]{2}{*}{$\begin{array}{c}\text { Contaminant of potential } \\
\text { concern }\end{array}$} & \multicolumn{2}{|c|}{ Median concentration in San Juan River } & \multirow[b]{2}{*}{ FWac } \\
\hline & $\begin{array}{c}\text { Adjacent and } \\
\text { downstream of site }\end{array}$ & Upstream of site & \\
\hline Antimony ${ }^{c}$ & 0.0059 & 0.0049 & $0.030^{\circ}$ \\
\hline Arsenic & 0.01 & 0.0075 & $0.19^{e}$ \\
\hline Magnesium ${ }^{c}$ & 11 & 10 & NA \\
\hline Sodium & 56 & 35 & NA \\
\hline Strontium & 1.1 & 0.83 & NA \\
\hline Sulfate & 192 & 118 & NA \\
\hline Thorium-230 & $0.3 \mathrm{pCi} / \mathrm{L}$ & $<0.4 \mathrm{pCi} / \mathrm{L}$ & NA \\
\hline
\end{tabular}

asampling locations 548,549,550,551,552,553, and 555 .

bSampling locations 546 and 554 .

'No unfiltered data are available for contaminants of potential concern. Therefore, filtered data are reported.

Filtered data are from the period of March 19, 1987, through April 22, 1989.

dDraft chronic FWOC for antimony (III) (EPA, 1988b).

${ }^{\text {e}}$ Chronic FWOC for arsenic (III) (EPA, 1986).

NOTE: All concentrations reported in milligrams per liter, unless specified otherwise. In most cases, unfiltered water samples from April 1993 are used.

NA - not available.

FWOC - FWOC for the protection of freshwater aquatic life via chronic exposure (EPA, 1986), unless specified otherwise. 
National Oceanic and Atmospheric Administration (NOAA) effects-based sediment quality values are available for evaluating the potential for constituents in sediment to cause adverse biological effects. "Effects range-low" (ER-L) values are concentrations equivalent to the lower 10th percentile of available data screened by the NOAA and indicate the low end of the concentration range in specific sediments at which adverse biological effects were observed or predicted in sensitive species and/or life stages.

NOAA sediment quality values are available for only one detected contaminant of potential concern, arsenic (Table 7.6). The mean arsenic concentrations upstream of the site $(1.9 \mathrm{mg} / \mathrm{kg})$ and downstream of the site $(2.5 \mathrm{mg} / \mathrm{kg})$ are well below the NOAA ER-L value of $33 \mathrm{mg} / \mathrm{kg}$. This suggests that the potential for arsenic to represent a hazard to aquatic life is low. Because there are no sediment quality values for the other contaminants of potential concern, it is not possible with the available information to determine if the detected sediment concentrations could adversely affect biota.

A comparison between the mean surface water concentrations for contaminants of potential concern upstream versus downstream of the site indicates that the concentrations were slightly higher downstream for arsenic, manganese, radium226, strontium, and uranium. Conversely, the concentrations of polonium-210 and thorium-230 were slightly higher upstream of the site. Antimony, magnesium, nitrate, sodium, and sulfate were not analyzed for in the river sediment samples, and the remaining ground water contaminants (cadmium, lead-210, and selenium) were not detected.

\subsection{POTENTIAL IMPACTS TO LIVESTOCK}

Impacted ground water under the floodplain may discharge to the drainage canal or may appear as surface water bodies during certain times of the year le.g., periods of high water in the San Juan River). The potential exists for livestock from the residences west of Bob Lee Wash to search the floodplain for food and water, ingesting vegetation that has bioconcentrated contaminants from alluvial ground water. However, without additional data (e.g., actual plant tissue concentrations), it is difficult to evaluate this exposure pathway.

To evaluate the potential impact to livestock that might drink out of the floodplain surface water bodies, the detected concentrations were compared to approximate drinking water concentrations considered to be protective of livestock (Table 7.7). A review of available comparison criteria suggests that livestock could use the floodplain surface water as a source of drinking water, with the exception of the wet area below seep 425 . The detected nitrate concentration $(236 \mathrm{mg} / \mathrm{L})$ in this area is more than twice the comparison criterion $(100 \mathrm{mg} / \mathrm{L})($ Table 7.7$)$. No comparison criteria are available for manganese, strontium, or uranium.

Based on past and current agricultural activities in the area surrounding the site, the possibility exists that ground water could be used in a livestock watering pond. To evaluate the potential impact to livestock in this future hypothetical scenario, the 
Table 7.6 Comparison of contaminants of concern in San Juan River sediment with avallable sediment quality screening levels, Shiprock, New Mexico, site

\begin{tabular}{|c|c|c|c|}
\hline \multirow{2}{*}{$\begin{array}{l}\text { Contaminant of } \\
\text { potential } \\
\text { concern }\end{array}$} & \multicolumn{2}{|c|}{ Mean concentration in San Juan River } & \multirow{2}{*}{$\frac{\text { NOAA values }}{\text { ER-L }}$} \\
\hline & $\begin{array}{l}\text { Adjacent to and downstream } \\
\text { of site }\end{array}$ & Upstream of site ${ }^{b}$ & \\
\hline Arsenic & 2.5 & 1.9 & 33 \\
\hline Manganese & 309 & 263 & NA \\
\hline Radium-226 & $1.3 \mathrm{pCi} / \mathrm{g}$ & $1.2 \mathrm{pCi} / \mathrm{g}$ & NA \\
\hline Strontium & 66 & 58 & NA \\
\hline Uranium & 4.5 & 4.2 & NA \\
\hline
\end{tabular}

aSampling locations $548,549,550,551,552,553$, and 555 .

bampling locations 546 and 554 .

All concentrations reported in milligrams per kilogram, unless specified otherwise.

NA - not available.

ER-L - effects range-low (NOAA, 1990).

$\mathrm{pCi} / \mathrm{g}$ - picocuries per gram. 


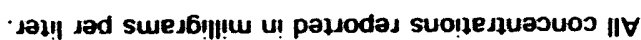

$\cdot(2<61) \forall \mathrm{d} \exists$ wos.

\begin{tabular}{|c|c|c|c|c|c|c|c|c|c|}
\hline$\forall N$ & 690 & $\varepsilon \varepsilon^{\prime} 0$ & 11 & 9900 & $\bullet 200$ & 1000 & $100.0>$ & $100.0>$ & wniuesn \\
\hline$\forall N$ & $\nabla \varepsilon L$ & $86 \varepsilon$ & $\varepsilon i L$ & LS'I & 26.1 & $\varepsilon \circ 1$ & 21 & Zl & un!̣uons \\
\hline $0 s 00$ & SEO O & $5000>$ & $5000>$ & $5000>$ & 9000 & $9000>$ & $5000>$ & $900.0>$ & uniuras \\
\hline$\infty \mathrm{ll}$ & $9 \varepsilon z$ & 91 & $8 \cdot 1$ & $9 \cdot 8$ & $\angle 8$ & $\varepsilon \downarrow$ & 0.1 & 21 & әle \\
\hline$\forall N$ & 100 & sio & $\forall 50$ & $\angle 20$ & $0 t \cdot 0$ & $100>$ & $\varepsilon 0^{\circ}$ & $\varepsilon 0^{\circ} 0$ & asauebuew \\
\hline 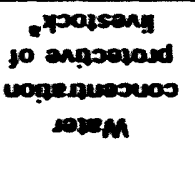 & $\begin{array}{c}659 \\
\text { al uopesol } \\
5270505 \\
\text { mopq } \\
\text { was som }\end{array}$ & $\begin{array}{l}199 \\
\frac{9 a}{500}\end{array}$ & $\begin{array}{l}099 \\
007 \\
06015\end{array}$ & 959 & $\begin{array}{c}\text { SS9 } \\
\frac{107}{9+10}\end{array}$ & $\begin{array}{r}299 \\
\text { spuepom }\end{array}$ & $\begin{array}{c}859 \\
\text { al uonex } \\
\text { a!josse put }\end{array}$ & $\begin{array}{c}\angle 99 \\
\text { ग207908 }\end{array}$ & $\begin{array}{l}\text { usosuos } \\
\text { fo zueupuezuoj }\end{array}$ \\
\hline
\end{tabular}

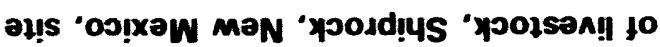

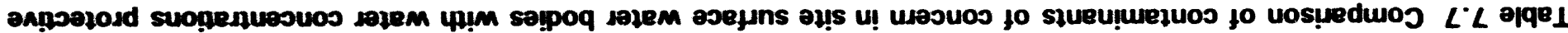


95 percent UCL ground water concentrations for the contaminants of concern are compared to approximate drinking water concentrations considered to be protective of livestock (EPA, 1972) (Table 7.2). The comparison water quality criteria for nitrate, selenium, and sulfate are exceeded by the 95 percent UCL ground water concentrations, while the 95 percent $U C L$ concentrations for the other contaminants of potential concern are below the comparison criteria. The ground water concentration of nitrate $(4220 \mathrm{mg} / \mathrm{L})$ is more than 1 order of magnitude above the comparison criterion $(100 \mathrm{mg} / \mathrm{L})$. Using this ground water as the sole source of drinking water for livestock would ultimately result in death to ruminants (e.g., cattle) from methemoglobinemia (Deeb and Sloan, 1975; NAS, 1972). No comparison water quality criteria are reported for the remaining contaminants of potential concern. However, the available information suggests the: using ground water as a source of drinking water for livestock would be unacceptable due to nitrate, selenium, and sulfate concentrations.

\subsection{ECOLOGICAL RISK ASSESSMENT LIMITATIONS}

The qualitative evaluation of potential ecological risks is a screening level assessment of the risks associated with potential exposure of plants and animals to contaminated ground water, surface water, and sediment at the Shiprock site. Sources of uncertainty in any ecological assessment arise from the monitoring data, exposure assessments, toxicological information, and the inherent complexities of the ecosystem. In addition, methods of predicting nonchemical stresses (e.g.. drought), biotic interactions, behavior patterns, biological variability (i.e., differences in physical conditions, nutrient availabilityl, and resiliency and recovery capacities are often unavailable. In general, limitations for the Shiprock ecological risk assessment include the following:

- Only a small amount of ecological data were collected during this screening.

- Little is known about site-specific intake rates for wildlife or amounts of contaminants taken up by plants. General literature values were used in many cases.

- Only limited ecotoxicological reference data are available.

- Considerable uncertainty is associated with the toxicity of mixtures of contaminants.

\subsection{SUMMARY}

Surface water data from the San Juan River indicate the presence of slightly higher concentrations for several contaminants of potential concern at locations adjacent to and downstream of the site. However, no clear trend suggests that site-related constituents adversely affected the water quality of the river. There are not enough data to adequately evaluate whether these concentrations represent a hazard to aquatic life. 
For many contaminants of potential concern, the sediment concentrations detected in the river at locations adjacent to and downstream of the site were higher than at the upstream locations. A qualitative evaluation of the sediment data suggests that past or current conditions at the site may trigger a release of the detected contaminants of potential concern. Concentrations of ar senic detected in the river sediments (both upstream and downstream of the site) are below the available sediment quality values. Sediment quality values or criteria are not available for most contaminants of concern; thus, the potential for these concentrations to represent an ecological concern cannot be evaluated with current data.

The unfiltered surface water and sediment samples collected from Bob Lee Wash and the floodplain surface water bodies were analyzed for selected contaminants of concern. Nitrate and selenium concentrations detected in water from the wet area below seep 425 may be of concern to aquatic life if chronic exposure occurs. None of the contaminants of potential concern analyzed for in the sediments have comparison sediment quality criteria. If additional information were available the potential for adverse effects to biota could be fully evaluated.

Potential current exposure to livestock using the floodplain for forage and drinking water was evaluated. A comparison of available livestock drinking water quality values with concentrations detected in the floodplain surface water bodies suggests that livestock could safely use these water bodies as their sole drinking water source, with the exception of the wet area below seep 425. The nitrate detected in this water exceeded the comparison criterion. However, these data represent only a snapshot in time and may not be representative of long-term conditions. Additional monitoring could provide information on possible temporal and seasonal variations in water and sediment quality.

Based on available data and criteria, no ecological threat exists to plants that may have roots in contact with the most contaminated ground water in the floodplain alluvial aquifer. However, this ground water is unsuitable for hypothetical future use as crop irrigation water because of its boron, manganese, and selenium concentrations and salinity and sodium hazards. Water from the most contaminated wells in this aquifer would not be suitable for fish to live in or as a sole source of drinking water for livestock.

The potential for the contaminants of concern detected in media at the site to represent a food chain hazard (via bioaccumulation and biomagnification) is considered low, based on available data. However, no plant or animal tissue analysis has been conducted to date.

Insufficient water quality criteria and sediment quality criteria were available to thoroughly evaluate the impacts of surface water, sediments, and contaminated ground water on ecological receptors. As with any qualitative ecological assessment, the uncertainties inherent in this assessment could be reduced through additional characterization and evaluation. 


\subsection{INTERPRETATION AND RECOMMENDATIONS}

\subsection{RISK SUMMARY}

The UMTRA lroject is required by the UMTRCA to protect public health and the environment from radiological and nonradiological hazards associated with the uranium mill sites. This baseline risk assessment was conducted on the Shiprock site to evaluate the presence of these hazards. Because ground water is currently not used by area residents, human health is not at risk from direct ground water uses. However, health risks would be associated with potential future use of contaminated ground water in the floodplain and terrace.

The primary risks associated with future use of contaminated ground water at the Shiprock processing site would result from ingestion of nitrates and sulfate by humans and other animals. Drinking plume ground water would result in nitrate intakes in the potentially lethal range for infants following short-term exposure. These nitrate levels are also unacceptable for domestic livestock and for wildlife. Sulfate levels in plume wells are associated with severe diarrhea and possible death due to dehydration. Lifetime excess cancer risks associated with uranium $11 \mathrm{x}$ $\left.10^{-3}\right)$ and arsenic $\left(1 \times 10^{-3}\right)$ are also at unacceptable levels.

Although the potential for current exposure to surface expressions of ground water exists in the area of the San Juan River floodplain near the Shiprock site, these exposures are not expected to immediately threaten public health. Additionally, adverse health effects would not be expected following ingestion of meat and milk from anımals grazed and watered on the San Juan River floodplain. However, this evaluation is based on very limited data. Additional data are required to completely evaluate the significance of these exposure pathways.

Adverse health effects would not be expected in humans who ingested meat and milk from animals grazed and watered on the San Juan River floodplain. However, nitrate levels exceed livestock drinking water criteria in at least one surface water location.

\subsection{LIMITATIONS OF THIS RISK ASSESSMENT}

The following limitations to this evaluation of health risks should be noted:

- This document evaluates risks associated with exposures only to inorganic contaminants of ground water at the UMTRA site near Shiprock. As discussed in Section 3.0, potential organic contaminants (those related to uranium processing) have not been considered.

- In general, the results presented in this document are based on filtered $(0.45 \mu \mathrm{m})$ water samples. The effect of filtration differs for different elements. Filtered samples can have somewhat lower or equal concentrations than unfiltered samples for some constituents. Constituents in suspension may be 
lost with filtration, but can still produce toxic effects if ingested and broken down in the acidic environment of the stomach.

- The toxicity of any contaminant varies from person to person. For example, normal variability in biochemical factors between individuals, differences in medical history, previous exposure to toxicants, and dietary and exercise habits can all affect susceptibility to chemical toxicity. In presenting ranges of exposures that can produce toxic effects, this assessment emphasizes that variability. However, it is not possible to account for all sources of variability and still present useful and meaningful analyses. Cases in which specific subpopulations of individuals are known to be more sensitive to toxic effects of given constituents have been noted. Using ranges for expected toxic effects provides the reader with a better understanding of the likelihood that toxicity will occur.

- To assess toxicity, standardized reference values developed by agencies such as the EPA and literature values are used to determine plant uptake. tissue concentrations in livestock, and toxic effects in humans. These reference values themselves have limitations including the following:

- Toxicity, uptake, and bioconcentration data are not available for all constituents elevated above background at the site.

- In some cases, data obtained from laboratory animal testing at exposure doses different from those expected at the site were used to determine toxicity. The relationship between dose and response is not always linear, and humans do not always exhibit the same responses as animals.

- Data used to determine toxicity are generally based on exposure to only the constituent of concern. In reality, exposures generally occur simultaneously to multiple chemicals. The interactive effects of multiple constituents and the impact of these interactions on expected toxicity generally cannot be accurately assessed from existing data.

- Although considerable effort has been directed at determining plume movement and placing monitor wells in locations that capture maximal contamination, variability in physical systems and models used to determine contaminant plume migration could still result in well placements that do not measure the highest contaminant concentrations or determine the fullest extent of plume impact.

- Variability can be introduced through sampling and analytical processes. However, the data at UMTRA Project sites have been collected over many years and subjected to rigorous quality assurance procedures. The use of multiple samples introduces high confidence in the reliability and validity of the collected data.

- The drinking water pathway is considered the major determinant of exposure in this assessment. Although other pathways were screened and determined not 
to contribute significantly to the total exposure, the additivity of exposure from these pathways should be kept in mind. Many of the factors in the nondrinking water pathways have considerable uncertainties that could affect these estimates by an order of magnitude.

By presenting ranges of toxic effects, summaries of available data on health effects and interactions, and outlines of potential limitations, this document provides a reasonable interpretation of potential health risks associated with ground water contamination at this site. This assessment presents both contamination and risk as accurately as possible, based on available data, and conveys areas of uncertainty.

\subsection{GROUND WATER CRITERIA}

In 1983, the EPA established health and environmental protection standards for the UMTRA Project. In 1987, the EPA proposed revised ground water standards. The UMTRA Project is required to adhere to the 1987 proposed ground water standards until final standards are published. The ground water standards consist of 11 ground water protection standards to evaluate disposal cell performance, and 2) ground water cleanup standards for existing contamination at processing sites. These standards are summarized in Table 8.1 for contaminants that have a proposed maximum concentration limit (MCL). The proposed standard requires meeting background levels for contaminants that do not have established MCLs.

While these ground water protection and cleanup standards apply to the UMTRA Project, the EPA has also published drinking water health advisory levels for both long-term and short-term exposures. These advisories are shown in Table 8.1.

The following contaminant concentrations in plume wells have consistently exceeded the EPA-proposed groundwater MCLs for UMTRA sites and/or the EPA health advisory levels: nitrate, selenium, cadmium, and uranium. Antımony la contaminant of concern without an $\mathrm{MCL}$ ) concentrations exceeded the 10-day advisory for a $10-\mathrm{kg}$ child and the lifetime health advisory for a $70 \cdot \mathrm{kg}$ adult. Boron, chromium, molybdenum, and vanadium marginally exceeded health advisories: however, the concentrations of these metals are not statistically above background. Strontium concentrations exceeded the lifetime health advisory for a $70-\mathrm{kg}$ adult but were not elevated above the 10-day health advisory for a $10-\mathrm{kg}$ child.

\subsection{RISK MITIGATION MEASURES}

Because serious health effects could follow short-term use of nitrate-contaminated ground water in the floodplain alluvium and the terrace alluvium, this section suggests ways to restrict access to ground water so as to mitigate risks.

Institutional controls are defined in the UMTRA proposed ground water standards as mechanisms that can effectively protect human health and the environment by controlling access to contaminated ground water. Although the proposed standards refer to institutional controls for long periods of time (e.g., up to 100 years during 
Table 8.1 Concentration limits of constituents

\begin{tabular}{|c|c|c|c|}
\hline Constituent & $\begin{array}{c}\text { UMTRCA MCL } \\
40 \text { CFR } 192.02 \\
(\mathrm{mg} / \mathrm{L})\end{array}$ & $\begin{array}{l}\text { Health advisories } \\
\text { 10-kg child, 10-day } \\
\text { (mg/L) }\end{array}$ & $\begin{array}{l}\text { Health advisories } \\
70-\mathrm{kg} \text { adult llfetime } \\
\text { (mg/L) }\end{array}$ \\
\hline \multicolumn{4}{|l|}{ Chemicals (Inorganic) } \\
\hline Antimony & - & $0.015^{a}$ & $0.003^{a}$ \\
\hline Arsenic & 0.05 & - & - \\
\hline Barium & 1.0 & $\cdot$ & 2 \\
\hline Boron & - & 0.9 & $0.6^{\circ}$ \\
\hline Cadmium & $0.01^{\mathrm{a}}$ & 0.04 & $0.005^{a}$ \\
\hline Chromium & $0.05^{a}$ & 1.0 & $0.1^{\circ}$ \\
\hline Copper & - & $\cdot$ & - \\
\hline Fluoride & - & $\cdot$ & . \\
\hline Lead & 0.05 & - & $0.015^{b}$ \\
\hline Manganese & - & - & - \\
\hline Mercury & 0.002 & - & 0.002 \\
\hline Molybdenum & 0.1 & $0.08^{c}$ & $0.04^{c}$ \\
\hline Nickel & - & 1.0 & 0.1 \\
\hline Nitrate & $44^{a, d}$ & $44^{\circ}$ & - \\
\hline Selenium & $0.01^{a}$ & $\cdot$ & - \\
\hline Silver & 0.05 & 0.2 & 0.1 \\
\hline Strontium & - & 25.0 & $17^{a}$ \\
\hline Sulfate & - & - & - \\
\hline Thallium & $\cdot$ & 0.007 & 0.0004 \\
\hline Vanadium & - & $0.08^{a, c}$ & $0.02^{a, c}$ \\
\hline Zinc & - & 6.0 & 2 \\
\hline \multicolumn{4}{|l|}{ Radionuclides } \\
\hline Radium-226/-228 & $5 \mathrm{pCi} / \mathrm{L}$ & - & - \\
\hline $\begin{array}{l}\text { Uranium } \\
\text { (U-234/-238) }\end{array}$ & $\begin{array}{c}30 \mathrm{pCi} / \mathrm{L}^{\mathrm{a}} \\
(0.044 \mathrm{mg} / \mathrm{L})\end{array}$ & $0.03 \mathrm{mg} / \mathrm{L}^{\prime}$ & $0.1 \mathrm{mg} / \mathrm{L}^{\dagger}$ \\
\hline
\end{tabular}

aExceeded in plume wells 608,609,610,611,613,614, or 615.

${ }^{b}$ Action level.

Exceeded in background.

${ }^{\mathrm{d}}$ Equal $10 \mathrm{mg} / \mathrm{L}$ nitrate as nitrogen.

Under review.

'Proposed value, under review; expected revision in 1995. 
natural flushing), this concept can also be applied to short-term or interim restriction of access to ground water. Because not all 24 UMTRA sites can be fully evaluated simultaneously, interim institutional controls are needed before remedial action decisions are made for individual sites.

The Navajo Nation Division of Natural Resources manages water resources within the Navajo Nation. Both this division and the Navajo Nation Environmental Protection Agency are responsible for water supply, standards, and discharge. The Division of Natural Resources is responsible for administering the water permit system and developing water-code compliance regulations for the Navajo Nation.

Currently, two permitting categories exist for water access: permits for well drilling and permits for water use. Both permits are necessary for drilling new wells. Permits usually undergo administrative and technical re iews. Agency implementation of institutional controls would be most effective at the technical review level. Tribal agencies and local authorities must agree to the technical criteria for implementing institutional control of ground water use.

After obtaining signature approval from the director of Water Resource Management, a permit is sent to the Navajo Department of Justice to determine jurisdictional issues or water rights problems. The permit is then reviewed by the Executive Director of the Division of Natural Resources to determine the potential for regional, political, or social concerns or impacts.

Establishing interim institutional controls to protect human health and the environment will require a consensus among Navajo Nation governmental agencies and local Navajo governing authorities and chapter houses. It would be most effective if local authorities would be responsible for monitoring new wells to ensure they have been approved. The governing authorities also will need to be informed of monitoring results and the expected duration of contamination problems. Chapter houses would be the most effective organizations for educating local residents about potential risks and the necessity of access restrictions.

Although the presence of a public water supply system largely reduces the likelihood of a well being installed at this site, interim institutional controls are needed to restrict access to contaminated water because short-term exposures could be lethal.

\subsection{RECOMMENDATIONS}

In general, the ground water standards of MCLs or background concentrations are sufficient to protect human health and the environment. However, in some cases, a risk assessment may identify site-specific factors that suggest these standards are too restrictive or not restrictive enough. When standards are too restrictive, there may be no potential for exposure, and a less restrictive alternate concentration limit (ACL) may be sought. In other cases, the standards may not be sufficiently protective (for example, if many contaminants are near the MCL with additive or synergistic adverse health effects). 
At Shiprock, no permanent physical barrier prevents access to contaminated ground water at the former processing site. Therefore, ACLs could not be justified for those constituents with MCLs. However, for those constituents that exceed background and do not have MCLs, this assessment suggests that background levels are more restrictive than necessary. This includes contaminants that were screened on the basis of their concentrations falling within nutritional levels (e.g., zinc) and other contaminants, such as strontium, that were demonstrated to be at concentrations well below adverse health effects levels. ACLs should be sought for these contaminants.

The nitrate $\mathrm{MCL}$ of $44 \mathrm{mg} / \mathrm{L}(10 \mathrm{mg} / \mathrm{L}$ as nitrogen) may not be sufficiently protective for infants where sulfate concentrations are also high. Further study of this potential synergism is needed before remedial action decisions are made for this site.

Nitrate levels present a serious health risk if the floodplain ground water at this site is used. The levels in monitor wells 908 and 915 substantially exceed levels at which fatal cases of methemoglobinemia have been reported elsewhere in infants. This situation requires that institutional controls be implemented as soon as possible, regardless of which remedial action strategy is pursued.

An additional round of surface water and sediment sampling is recommended for the San Juan River and the floodplain surface water bodies during a low-flow period in the river. These data would provide information on the contribution of ground water to these water bodies.

Also, samples of plant and animal tissue should be collected from the floodplain and from a background location. These data would be useful in assessing bioaccumulation and the potential for food chain transfer.

The terrace alluvium ground water hydrology, background ground water chemistry, and the areal and vertical extent of contamination require more characterization. Existing data are not sufficient for identifying mill-related potential contaminants and receptors or for precisely evaluating potential risks associated with the future uses of the terrace ground water. However, the aquifer yield seems to be very low, and using ground water as a drinking water resource is questionable. Other future beneficial uses of the terrace ground water (for example, for livestock watering or crop irrigation) should be evaluated. 


\subsection{LIST OF CONTRIBUTORS}

The following individuals contributed to the preparation of this report.

\begin{tabular}{ll}
\hline Name & Contribution \\
\hline B. Malczewska-Toth & $\begin{array}{l}\text { Overall document responsibility; } \\
\text { authorship }\end{array}$ \\
L. Flowers & Document technical review \\
C. Day & Ecology \\
K. Smith & Statistics \\
A. Groffman & Geochemistry \\
D. Tarbox & Hydrogeology \\
R. Neri Zegal & Institutional controls \\
E. Bond & Graphic design \\
J. Torline, D. Thalley & Technical editing \\
L. Keith, C. Slosberg, WordCenter Inc. & Word processing \\
\hline
\end{tabular}




\subsection{REFERENCES}

AHFS (American Hospital Formulary Service), 1991. Gerald McEvoy, ed., American Society of Hospital Pharmacy, Bethesda, Maryland, pp. 1506, 1706.

Aikawa, J. K., 1963. The Role of Magnesium in Biologic Processes, C. C. Thomas, publisher, Springfield, Illinois.

Allison et al. (J. D. Allison, D. S. Brown, and K. J. Novo-Gradac), 1991. MINTEQA2/ PRODEFA2, A Geochemical Assessment Model for Environmental Systems: Version 3.0 User's Manual, EPA/600/3-91/021.

Baes et al. (C. F. Baes III, R. D. Sharp, A. L. Sjoreen, and R. W. Shorl, 1984. A Review and Analysis of Parameters for Assessing Transport of Environmentally Released Radionuclides Through Agriculture, ORNL-5786, prepared for Oak Ridge National Laboratory, Health and Safety Research Division, Oak Ridge, Tennessee.

Ballou et al. (J. E. Ballou, R. A. Gies, A. C. Case, D. L. Haggard, R. L. Buschbom, and J. L. Ryan), 1986. "Deposition and Early Disposition of Inhaled Uranium-233 Uranyl Nitrate and Uranium-232 Uranyl Nitrate in the Rat," in Health Physics, No. 51, pp. 755-772.

Berlin, M., and B. Rudell, 1986. "Uranium," Handbook on the Toxicology of Metals, Volume II, Specific Metals, second edition, L. Friberg, G. F. Nordberg, and V. B. Vouk, eds., Elsevier Science Publishers B.V., Amsterdam, pp. 647-658.

Bland, R. G., and H. E. Jaques, 1978. How to Know the Insects, third edition, William C. Brown, publisher, Dubuque, lowa.

Bolyai et al. (J. Z. Bolyai, R. P. Smith, and C. T. Gray), 1972. "Ascorbic Acid and Chemically Induced Methemoglobinemias," in Toxicological Applied Pharmacology, No. 21 , pp. 176-185.

Bopp et al. (B. A. Bopp, R. C. Sanders, and J. W. Kesterson), 1982. "Metabolic Fate of Selected Selenium Compounds in Laboratory Animals and Man," in Drug Metabolism Review, No. 13, pp. 271-318.

Buchet et al. (J. P. Buchet, R. Lauwerys, and H. Roels), 1990. "Renal Effects of Cadmium Body Burden of the General Population," in Lancet, Vol. 336, pp. 669-702.

Buchet et al. (J. P. Buchet, R. Lauwerys, and H. Roels), 1981. "Urinary Excretion of Inorganic Arsenic and its Metabolites After Repeated Ingestion of Sodium Metaarsenite by Volunteers", in International Archives of Occupational and Environmental Health, No. 48, pp. 111-118. 
Buchet et al. (J. P. Buchet, H. Roels, and R. Lauwerys), 1980. "Repeated Surveillance of Exposure to Cadmium, Manganese, and Arsenic in School-Age Children Living in Rural, Urban, and Nonferrous Smelter Areas in Belgium," in Environmental Research, No. 22, pp. 95-108.

Burton, G. A., Jr., 1991. "Assessing the Toxicity of Freshwater Sediments," in Environmental Toxicology and Chemistry, No. 10, pp. 1585-1627.

Calabrese, E. J., and R. W. Tuthill, 1977. "Elevated Blood Pressure and High Radium Levels in the Public Drinking Water," in Archives of Environmental Health, September/October 1977, pp. 200-202.

Carson et al. (B. L. Carson, H. V. Ellis III, and J. L. McCann), 1986. Toxicology and Biological Monitoring of Metals in Humans, Lewis Publishers, Inc., New York, New York, pp. 226-230.

Casarett, L. J., and J. Doull, 1991. Toxicology: The Basic Science of Poisons, fourth edition, M. O. Amdur, J. Doull, and C. D. Klaassen, eds., Pergamon Press, New York, New York.

Chapman, P. M., 1989. "Current Approaches to Developing Sediment Quality Criteria," in Environmental Toxicology and Chemistry, No. 8, pp. 598-599.

Charley, R., 1993. The Navajo UMTRA Program, personal communication with Barbara Malczewska-Toth, Radiological Services, Jacobs Engineering Group Inc., UPDCC File Location No. 4.17.4.2, Albuquerque, New Mexico, February 2, 1993.

Comar, C. L., and R. H. Wasserman, 1964. "Strontium," in Mineral Metabolism, C. L. Comar and F. Bronner, eds., Vol. II, Part A, Academic Press, New York and London, pp. 523-572.

Cothern, C. R., and W. L. Lappenbusch, 1983. "Occurrence of Uranium in Drinking Water in the United States," in Health Physics, No. 45, pp. 89-99.

Crecelius, E. A., 1977. "Changes in the Chemical Speciation of Arsenic Following Ingestion by Man," in Environmental Health Perspective, No. 19, pp. 147-150.

Cummins, L. M., and E. T. Kimura, 1971. "Safety Evaluation of Selenium Sulfide Antidandruff Shampoos," in Toxicology and Applied Pharmacology, No. 20, pp. 89-96.

Curzon, M. E. J., 1985. "The Relation Between Caries Prevalence and Strontium Concentrations in Drinking Water, Plaque, and Surface Enamel," in Journal of Dental Research, No. 64(12), pp. 1386-1388.

DHHS (U.S. Department of Health and Human Services), 1993a. "Toxicological Profile for Arsenic," prepared by Life Systems, Inc., for Clement International Corporation for the U.S. Department of Health and Human Services. 
DHHS (U.S. Department of Health and Human Services), 1993b. "Toxicological Profile for Cadmium," prepared by Life Systems, Inc., for Clement International Corporation for the U.S. Department of Health and Human Services.

DHHS (U.S. Department of Health and Human Services), 1992. "Toxicological Profile for Manganese and Compounds," prepared by Life Systems Inc., for Clement International Corporation for the U.S. Department of Health and Human Services.

DHHS (U.S. Department of Health and Human Services), 1989. "Toxicological Profile for Selenium," prepared by Clement Associates, for the U.S. Department of Health and Human Services.

DOE (U.S. Department of Energy), 1991. Escarpment Seeps at Shiprock, New Mexico, UMTRA-DOE/AL-350214.0000, June 1991, prepared by the U.S. Department of Energy, UMTRA Project Office, Albuquerque Operations Office, Albuquerque, New Mexico.

DOE (U.S. Department of Energy), 1990. "Plan for Control of Vegetation at the Shiprock, New Mexico, Disposal Site," draft, August 1990, prepared by the U.S. Department of Energy, UMTRA Project Office, Albuquerque Operations Office, Albuquerque, New Mexico.

DOE (U.S. Department of Energy), 1989. Attachment 1, Modifications to the Remedial Action Plan and Site Conceptual Design for Stabilization of the Inactive Uranium Mill Tailings Site at Shiprock, New Mexico, UMTRA-DOE/AL-050504.0039, revised final, U.S. Department of Energy, UMTRA Project Office, Albuquerque Operations Office, Albuquerque, New Mexico.

DOE (U.S. Department of Energy), 1985. Remedial Action Plan and Site Conceptual Design for Stabilization of the Inactive Uranium Mill Tailings Site at Shiprock, New Mexico, UMTRA-DOE/AL-050504.0000, June 1985, prepared by the U.S. Department of Energy, UMTRA Project Office, Albuquerque Operations Office, Albuquerque, New Mexico.

DOE (U.S. Department of Energy), 1984. Environmental Assessment of Remedial Action at the Shiprock Uranium Mill Tailings Site, Shiprock, New Mexico, DOE/EA-0232, May 1984, prepared by the U.S. Department of Energy, UMTRA Project Office, Albuquerque Operations Office, Albuquerque, New Mexico.

Deeb, B. S., and K. W. Sloan, 1975. Nitrates, Nitrites, and Health, University of Illinois, Colleges of Agriculture and Veterinary Medicine, Agricultural Experiment Station, Bulletin 750 .

Di Toro et al. (D. M. Di Toro, C. S. Zarba, D. J. Hansen, W. J. Berry, R. C. Swartz, C. E. Cowan, S. P. Pavlou, H. E. Allen, N. A. Thomas, and P. R. Paquin), 1991. "Technical Basis for Establishing Sediment Quality Criteria for Nonionic Organic Chemicals Using Equilibrium Partitioning," in Environmental Toxicology and Chemistry, No. 10, pp. 1541-1583. 
EPA (U.S. Environmental Protection Agency), 1993. "Integrated Risk Information System (IRIS)," data base, Office of Research and Development, Washington, D.C.

EPA (U.S. Environmental Protection Agency), 1992a. Drinking Water Criteria Document for Sulfate, final, Hisalth and Environmental Criteria Division, Office of Science and Technology, U.S. Environmental Protection Agency.

EPA (U.S. Environmental Protection Agency), 1992b. "Toxic Substance Spreadsheet," Region IV, U.S. Environmental Protection Agency, Atlanta, Georgia.

EPA (U.S. Environmental Protection Agency), 1991. "Integrated Risk Information System (IRIS)," data base, Office of Research and Development, Washington, D.C.

EPA (U.S. Environmental Protection Agency), 1990. Drinking Water Criteria Document for Stable Strontium, prepared by the Office of Health and Environmental Assessment, Environmental Criteria and Assessment Office, Cincinnati, Ohio, for the Office of Drinking Water, Washington, D.C.

EPA (U.S. Environmental Protection Agency), 1989a. Risk Assessment Guidance for Superfund, Volume II, Environmental Evaluation Manual, EPA/504/1-89/001, Office of Emergency and Remedial Response, Washington, D.C.

EPA (U.S. Environmental Protection Agency), 1989b. Briefing Report to the EPA Science Advisory Board on the Equilibrium Partitioning Approach to Generating Sediment Quality Criteria, Office of Water Regulations and Standards, Criteria and Standards Division, Washington, D.C.

EPA (U.S. Environmental Protection Agency), 1988a. "Integrated Risk Information System (IRIS)," data base, Office of Research and Development, Washington, D.C.

EPA (U.S. Environmental Protection Agency), 1988b. "Ambient Aquatic Life Water Quality Criteria for Antimony (III)," draft, Office of Research and Development, Duluth, Minnesota, and Narragansett, Rhode Island.

EPA (U.S. Environmental Protection Agency), 1988c. Interim Sediment Criteria Values for Nonpolar Hydrophobic Organic Contaminants, Office of Water Regulations and Standards Division, Washington, D.C.

EPA (U.S. Environmental Protection Agency), 1986. Quality Criteria for Water, EPA 440/5-86-001, Office of Regulations and Standards, Washington, D.C.

EPA (U.S. Environmental Protection Agency), 1984. Health Assessment Document: Inorganic Arsenic, U.S. Environmental Protection Agency, Washington, D.C. 
EPA (U.S. Environmental Protection Agency), 1980. Ambient Water Quality Criteria for Selenium, EPA 440/5-80-070, NTIS PB 81-117814, prepared by the Office of Health and Environmental Assessment, Environmental Criteria and Assessment Office, Cincinnati, Ohio, for the Office of Water Quality Planning Standards, Washington, D.C.

EPA (U.S. Environmental Protection Agency), 1972. Water Quality Criteria, National Academy of Sciences and National Academy of Engineering, Washington, D.C.

FBDU (Ford, Bacon and Davis Utah, Inc.), 1981. Engineering Assessment of Inactive Uranium Mill Tailings, Shiprock Site, Shiprock, New Mexico, DOE/UMT-0104 FBDU 360-02 UC 70, July 1981, prepared by Ford, Bacon and Davis Utah, Inc., for the U.S. Department of Energy, UMTRA Project Office, Albuquerque Operations Office, Albuquerque, New Mexico.

Ferm, V. H., 1971. "The Teratogenic Profile of Sodium Arsenate in the Golden Hamster," Archives of Environmental Health, No. 22, pp. 557-560.

Fisenne et al. (I. M. Fisenne, P. M. Perry, and N. H. Harley), 1988. "Uranium in Humans," in Rad. Prot. Dosim., No. 24, pp. 127-131.

Flanagan et al. (P. R. Flanagan, J. S. McLellan, J. Haist, M. G. Cherian, M. J. Chamberlain, and L. S. Valberg), 1978. "Increased Dietary Cadmium Absorption in Mice and Human Subjects with Iron Deficiency," in Gastroenterology, Vol. 74, pp. 841-846.

Follett, R. H., and P. N. Soltanpour, 1985. "Irrigation Water Quality Criteria," Colorado State University Extension Service, publication number 506.

Freis, E. D.. 1976. "Salt, Volume and the Prevention of Hypertension," in Circulation Vol. 53, No. 4, pp. 589-595.

Friberg et al. (L. Friberg, G. F. Nordberg, and V. B. Vouk), 1986a. Handbook on the Toxicology of Metals, Volume II: Specific Metals, second edition, Elsevier Science Publishers B.V., Amsterdam.

Friberg et al. (L. Friberg, T. Kjellström, and G. F. Nordberg), 1986b. "Cadmium," Handbook on the Toxicology of Metals, second edition, L. Friberg, G. F. Nordberg and V. Vouk, eds., Elsevier Science Publishers B. V., Amsterdam.

Gover, Robert A., 1991. "Toxic Effects of Metals," Toxicology: The Basic Science of Poisons, fourth edition, M. O. Amdur, J. Doull, and C. D. Klaassen, eds., Pergamon Press, New York, New York, pp. 623-680.

Hans, J. M., 1977. EPA Las Vegas Facility, personal communication with H. Tso, Executive Director, Navajo Environmental Protection Commission, Window Rock, Arizona, UPDCC File Location No. 4.19.2.9, Albuquerque, New Mexico, July 13, 1977. 
Hood, R. D., 1983. "Toxicology of Prenatal Exposure to Arsenic," Arsenic: Industrial, Biomedical, Environmental Perspectives, W. H. Lederer and R. J. Fensterheim, eds, Van Nostrand Reinhold Company, New York, New York.

Hood, R. D., 1972. "Effects of Sodium Arsenite on Fetal Development," in Bulletin of Environmental Contamination and Toxicology, No. 7, p. 216.

Hoy, W., 1993. Lovelace Medical Foundation, personal communication with J. Lewis, Jacobs Engineering Group Inc., UPDCC File Location No. 4.27.5, Albuquerque, New Mexico, May 26, 1993.

Hunt, R. E., 1984. Geotechnical Engineering Investigation Manual, McGraw-Hill Book Company, New York, New York, pp. 149-157.

IARC (International Agency for Research on Cancer), 1987. IARC Monographs on the Evaluation of the Carcinogenic Risk of Chemicals to Humans, Supplement 7.

Ishinishi et al. (N. Ishinishi, K. Tsuchiya, M. Vahter, and B. A. Fowler), 1986. "Arsenic," Handbook on the Toxicology of Metals, Volume II: Specific Metals, second edition, Elsevier Press Science Publishers B.V., Amsterdam.

JEG (Jacobs Engineering Group Inc.), n.d. Albuquerque Operations Manual, standard operating procedures, prepared by Jacobs Engineering Group Inc., Albuquerque, New Mexico, for the U.S. Department of Energy, UMTRA Project Office, Albuquerque Operations Office, Albuquerque, New Mexico.

Kabata-Pendias, A., and H. Pendias, 1992. Trace Elements in Soils and Plants, second edition, CRC Press, Boca Raton, Florida.

Kamm et al. (L. Kamm, G. G. McKeown, and D. M. Smith), 1965. "New Colorimetric Method for the Determination of the Nitrate and Nitrite Content of Baby Foods," in J. Assoc. Offic. Agr. Chemists, No. 48, p. 892.

Kenaga, E. E., 1980. "Predicted Bioconcentration Factors and Soil Sorption Coefficients of Pesticides and Other Chemicals," in Ecotoxicology and Environmental Safety, No. 4. pp. 26-38.

Kjellström, T., and G. E. Nordberg, 1978. "A Kinetic Model of Cadmium Metabolism in the Human Being," in Environmental Research, Vol. 16, pp. 248-269.

Kondakis et al. (X. G. Kondakis, N. Makris, M. Leotsinidis, M. Prinou, and T. Papapetropoulos), 1989. "Possible Health Effects of High Manganese Concentration in Drinking Water," in Archives of Environmental Health, Vol. 44, No. 3, pp. 175-178. 
Leach et al. (L. J. Leach, R. M. Gelein, B. J. Panner, C. L. Ylie, and C. C. Cox), 1984. The Acute Toxicity of the Hydrolysis Products of Uranium Hexafluoride (UF6) When Inhaled by the Rat and Guinea Pig, final report, ISS K/SUB-81-9039-3, NTIS DE84011539.

Lee, D. H. K., 1970. "Nitrates, Nitrites, and Methemoglobinemia," in Environmental Research, No. 3, pp. 484-511.

Lindgren et al. (A. Lindgren, M. Vahter, and L. Dencker), 1982. "Autoradiographic Studies on the Distribution of Arsenic in Mice and Hamsters Administered ${ }^{74}$ As-arsenite or -arsenate," in Acta Pharmacology and Toxicology, No. 51, pp. 253-265.

Lönnerdal et al. (B. Lönnerdal, C. L. Keen, J. G. Bell, and B. Sandstrom), 1987. "Manganese Uptake and Retention," Nutritional Bioavailability of Manganese, C. Kies, ed., American Chemical Society Symposium Series 354, pp. 9-20, American Chemical Society, Washington, D.C.

Marafante, E., and M. Vahter, 1987. "Solubility, Retentions and Metabolism of Intratracheally and Orally Administered Inorganic Arsenic Compounds in Hamsters," in Environmental Research, No. 42, pp. 72-82.

Marcus, W. L., and A. S. Rispin, 1988. "Threshold Carcinogenicity Using Arsenic as an Example," Advances in Environmental Toxicology, Volume XV, Risk Assessment and Risk Management of Industrial and Environmental Chemicals, C. R. Cothern, M. A. Mehlman, and W. L. Marcus, eds., Princeton Scientific Publishing Co., New Jersey, pp. 133-159.

Marie et al. (P. J. Marie, M. T. Garba, M. Hott, and L. Miravet), 1985. "Effect of Low Doses of Stable Sr on Bone Metabolism in Rats," in Miner. Electrolyte Metab., No. 11, pp. 5-13.

Maynard, E. A., and H. C. Hodge, 1949. "Study of Toxicity of Various Uranium Compounds When Fed to Experimental Animals," Pharmacology and Toxicology of Uranium Compounds, National Nuclear Energy Services, Div. VI, Vol. 1, C. Voegtlin and H. C. Hodge, eds., McGraw Hill, New York, New York, pp. 309-376.

McCaslin, F. E., and J. M. Janes, 1959. "The Effect of Strontium Lactate in the Treatment of Osteoporosis," cited after IRIS, 1992, Proceedings of the Mayo Clinic, No. 34(13), pp. 329-334.

McLean, J. S., and I. A. Johnson, 1987. Aquifers of the Western Mountain Area, AWRA Monograph Series, No. 14, pp. 203-217.

Medinsky et al. (M. A. Medinsky, R. G. Cuddihy, and R. O. McClellan), 1981. "Systemic Absorption of Selenious Acid and Elemental Selenium Aerosols in Rats," in Journal of Toxicology and Environmental Health, No. 8, pp. 917-928. 
Mena et al. (I. Mena, K. Horiuchi, K. Burke, and G. C. Cotzias), 1969. "Chronic Manganese Poisoning, Individual Susceptibility and Adsorption of Iron," in Neurology, No. 19, pp. 1000-1006.

Meneely, G. R., and H. D. Battarbee, 1976. "Sodium and Potassium," in Nutrition Reviews, No. 8, pp. 225-235.

Moriarty, F., 1988. Ecotoxicology: The Study of Pollutants in Ecosystems, second edition, Academic Press, New York, New York.

Morrison et al. (G. M. P. Morrison, G. E. Batley, and T. M. Florence), 1989. "Metal Speciation and Toxicity," in Chem. Br., No. 25, p. 791.

NAS (National Academy of Sciences), 1972. Accumulation of Nitrate, Committee on Nitrate Accumulation, Agricultural Board, Division of Biology and Agriculture, National Research Council, Washington, D.C.

NCRP (National Council on Radiation Protection and Measurements), 1984. "Exposures from the Uranium Series With Emphasis on Radon and its Daughter," NCRP Report No. 77, Bethesda, Maryland.

NOAA (National Oceanic and Atmospheric Administration), 1990. "The Potential for Biological Effects of Sediment-Sorbed Contaminants Tested in the National Status and Trends Program," NOAA technical memo, NOS OMA 52.

NRC (National Research Council), 1980. Drinking Water and Health, Volume 3, Safe Drinkıng Water Committee.

NRC (National Research Council), 1973. Medical and Biological Effects of Environmental Pollutants: Manganese, Committee on Biologic Effects of Atmospheric Pollutants, Division of Medical Sciences.

NTUA (Navajo Tribal Utility Authority), 1993. Personal communication with Len Flowers, Jacobs Engineering Group Inc., UPDCC File Location No. 4.17.4.2, Albuquerque. New Mexico, March 1993.

Nordberg et al. (G. F. Nordberg, T. Kjellström, and M. Nordberg), 1985. Cadmium and Health: A Toxicological and Epidemiological Appraisal, Ch. 6, L. Friberg, C. G. Elinder, T. Kjellström, and G. F. Nordberg, eds., CRC Press, Boca Raton, Florida.

ORNL (Oak Ridge National Laboratory), 1984. A Review and Analysis of Parameters for Assessing Transport of Environmentally Released Radionuclides Through Agriculture, ORNL-5786, Health and Safety Research Division, Oak Ridge National Laboratory, Oak Ridge, Tennessee.

Pershagen, G., and M. Vahter, 1979. Arsenic, Swedish Environmental Protection Board, Stockholm, Sweden. 
Prister, B. S., 1969. GKIAE Report by Atomizdat, Moscow (Canadian translation AEC/TR/7178 (1970), and USCEAR Rep. A/AC.82/G/L 1298).

Rosenfeld, I., and O. A. Beath, 1964. Selenium, Geobotany, Biochemistry, Toxicity, and Nutrition, Academic Press, New York.

Saric, M., 1986. "Manganese," Handbook on the Toxicology of Metals, Volume II, L. Friberg, G. F. Nordberg, and V. B. Vouk, eds., Elsevier Science Publishers B.V., Amsterdam, pp. 354-386.

Shannon, R. L., and D. S. Strayer, 1989. "Arsenic-Induced Skin Toxicity," in Human Toxicology, No. 8, pp. 99-104.

Shea, D., 1988. "Developing National Sediment Quality Criteria," in Environmental and Scientific Technology, No. 22(11), pp. 1256-1261.

Smith, G. E., 1966. "Causes of Nitrate Accumulation in Plants and Water Supplies," paper to 18th Annual Midwest Fertilizer Conference, Chicago, Illinois.

Snyder et al. IW. S. Snyder, M. J. Cook, E. S. Nasset, L. R. Karhausen, G. P. Howells, and I. H. Tipton), 1975. Report of the Task Group on Reference Man, International Conimission on Radiological Protection (ICRP), ICRP publication 23, New York, New York.

Stevens et al. IW. F. Stevens, W. Bruenger, D. R. Atherton, J. M. Smith, and

G. N. Taylor), 1980. "The Distribution and Retention of Hexavalent ${ }^{233} \mathrm{U}$ in the Beagle," in Radiat. Res., No. 83, pp. 109-126.

Storey, E., 1961. "Strontium 'Rickets,' Bone Calcium and Strontium Changes," in Australian Annals of Medicine, No. 10, pp. 213-222.

Sullivan et al. (M. F. Sullivan, P. S. Ruemmler, J. L. Ryan, and R. L. Bushhom), 1986. "Influence of Oxidizing or Reducing Agents on Gastrointestinal Absorption of $\mathrm{U}, \mathrm{Pu}$, Am, Cm, and Pm by Rats," in Health Physics, No. 50, pp. 223-232.

Summerskill, W. H. J., and E. Wolpert, 1970. "Ammonia Metabolism in the Gut," in American Journal of Clinical Nutrition, Vol. 23, pp. 633-639.

TAC (Technical Assistance Contractor), 1993. "Survey of Water Use," conducted by the Technical Assistance Contractor, Jacobs Engineering Group Inc., for the U.S. Department of Energy, UMTRA Project Office, Albuquerque Operations Office, UPDCC File Location No. 4.17.4.2, Albuquerque, New Mexico, January 1993.

Thiers, G. R., 1986. Morrison-Knudsen Engineers, Inc., "Shiprock Remedial Action Case Study," presented at the U.S. Department of Energy Remedial Action Programs Conference, Oak Ridge, Tennessee, May 6, 1986. 
Tracy et al. (B. L. Tracy, J. M. Quinn, J. Lahey, A. P. Gilman, K. Mancuso, A. P. Yagdinas, and D. C. Villeneuvel, 1992. "Absorption and Retention of Uranium from Drinking Water by Rats and Rabbits," in Health Physics, Vol. 62, pp. 65-73.

Tracy et al. (B. L. Tracy, F. A. Prantl, and J. M. Quinn), 1983. "Transfer of ${ }^{226} \mathrm{Ra}{ }^{210} \mathrm{~Pb}$, and Uranium from Soil to Garden Produce: Assessment of Risk," in Health Physics, Vol. 44, p. 469.

Tseng, W. P., 1977. "Effects and Dose-Response Relationship of Skin Cancer and Blackfoot Disease with Arsenic," in Environmental He th Perspectives, No. 19, pp. 109-119.

Venugopal, B., and T. D. Luckey, 1978. "Chemical Toxicity of Metals and Matalloids," Metal Toxicity in Mammals, Plenum Press, New York, New York.

WHO (World Health Organization), 1981. Arsenic, Environmental Health Criteria 18, Geneva, Switzerland.

Weigel, F., 1983. "Uranium and Uranium Compounds," Kirk-Othmer Encyclopedia of Chemical Technology, Vol. 23, third edition, M. Grayson, ed., John Wiley and Sons, New York, New York, pp. 502-547.

Wrenn et al. (M. E. Wrenn, P. W. Durbin, B. Howard, J. Lipsztein, J. Rundo, E. T. Still, and D. L. Willis), 1985. "Metabolism of Ingested $U$ and Ra," in Health Physics, No. 48, pp. 601-633.

Yang et al. (G. Yang, R. Zhou, and S. Yin), 1989a. "Studies of Safe Maximal Daily Dietary Selenium Intake in a Seleniferous Area in China, " I, in Journal of Trace Elements, Electrolytes, Health Diseases, No. 3(2), pp. 77-87.

Yang et al. (G. S. Yang, R. Zhou, and S. Yin), 1989b. "Studies of Safe Maximal Daily Dietary Selenium Intake in a Seleniferous Area in China," II, Relation Between Selenium Intake and the Manifestation of Clinical Signs and Certain Biochemical Alterations in Blood and Urine," in Journal of Trace Elements, Electrolytes, Health Diseases, No. 3(2), pp. 123-130.

\section{CODE OF FEDERAL REGULATIONS}

10 CFR Part 40, "Domestic Licensing of Source Material," U.S. Nuclear Regulatory Commission (1993).

\section{UNITED STATE CODE}

42 USC $\$ 7901$ et seq., Uranium Mill Tailings Radiation Control Act, November 8, 1978. 

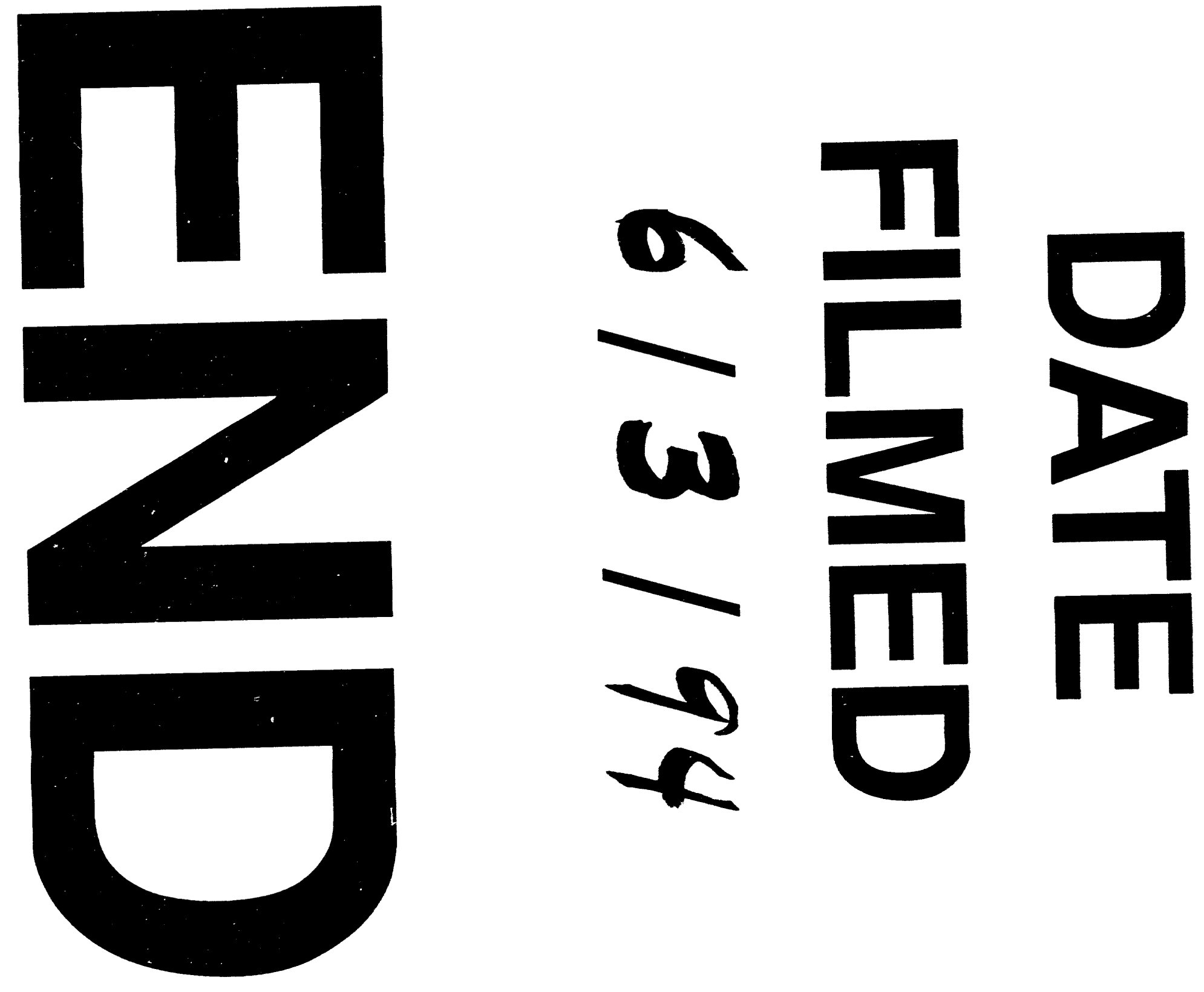